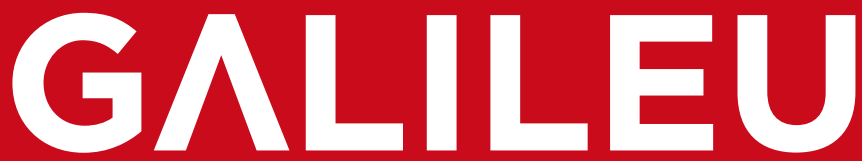

REVISTA

DE DIREITO

E ECONOMIA 


\section{GALILEU - REVISTA DE DIREITO E ECONOMIA}

VOLUME XX $\cdot$ Issue $2 \cdot 1^{\text {st }}$ July $-31^{\text {st }}$ December 2019

Semiannual Publication. Scientific Journal of the Ratio Legis - Centro de Investigação e Desenvolvimento em Ciências Jurídicas from the Universidade Autónoma de Lisboa - Luís de Camões.

\section{DIRECTORY}

Repositório Científico de Acesso Aberto de Portugal (RCAAP).

\section{DATABASES}

Repositório Institucional da Universidade Autónoma de Lisboa (Camões).

\section{GALILEU - REVISTA DE DIREITO E ECONOMIA}

VOLUME XX · Fascículo $2 \cdot 1$ de julho - 31 de dezembro 2019

Publicação semestral. Revista Científica do Ratio Legis - Centro de Investigação e Desenvolvimento em Ciências Jurídicas da Universidade Autónoma de Lisboa - Luís de Camões.

DIRETÓRIOS

Repositório Científico de Acesso Aberto de Portugal (RCAAP).

BASE DE DADOS

Repositório Institucional da Universidade Autónoma de Lisboa (Camões). 
PUBLISHING INSTITUTION INSTITUIÇÃO EDITORA

CEU - Cooperativa de Ensino Universitário, C.R.L.

EDIUAL - Universidade Autónoma Editora

Rua de Santa Marta, 47 - 1150-293 Lisboa

PHONE TELEFONE +351 $213177667 \cdot$ e-mail: galileu@autonoma.pt

Este trabalho é financiado por Fundos Nacionais através da FCT - Fundação para a Ciência e a Tecnologia no âmbito do projecto Ref." : UID/DIR/04441/2019.

This work was funded by national funds through FCT - Fundação para a Ciência e a Tecnologia - as part the project Ratio Legis - Ref." : UID/DIR/04441/2019.

E-ISSN 2184-1845

DOI https://doi.org/10.26619/2184-1845.XX.1

LEGAL DEPOSIT DEPÓSITO LEGAL 450625/19

TITLE TÍTULO Galileu - Revista de Direito e Economia

SITE http://journals.ual.pt/galileu/

REgISTRATION Status Under Publishing SituaçÃo de Registo Em Publicação

FORMAT SUPORTE Online

REGISTRATION ERC Notation INSCRIÇÃo Anotada na ERC

PERIODICITY Semiannual PERIODICIDADE Semestral

EDITOR IN CHIEF DIRETOR EDITOR Ruben Bahamonde

ASSISTANT DIRECTORS DIRETORES ADJUNTOS Alex Sander Xavier Pires, Manuel Guedes Valente SCIENTIFIC EDITOR EDITOR CIENTÍFICO RATIO LEGIS 


Ruben Bahamonde Universidade Autónoma de Lisboa, Portugal rbahamonde@autonoma.pt

\section{ASSISTANT DIRECTORS DIRETORES ADJUNTOS}

\begin{tabular}{ll}
\hline Alex Sander Xavier Pires & Universidade Autónoma de Lisboa, Portugal aspires@autonoma.pt \\
\hline Manuel Guedes Valente & Universidade Autónoma de Lisboa, Portugal mvalente@autonoma.pt \\
\hline
\end{tabular}

\section{EDITORIAL BOARD CONSELHO EDITORIAL}

\begin{tabular}{lll}
\hline Aloísio Cristóvão dos Santos Júnior & Centro Universitário Estácio da Bahia, Brasil & acristovamjr@gmail.com \\
\hline António Carlos dos Santos & Universidade Europeia, Portugal & acsantos@iseg.utl.pt \\
\hline Constança Urbano de Sousa & Universidade Autónoma de Lisboa, Portugal & mconstanca@autonoma.pt \\
\hline Fernando Cachafeiro Garcia & Universidade da Coruña, Espanha & fernando.cachafeiro@ude.es \\
\hline Francisco Hernández & $\begin{array}{l}\text { Universidade de Santiago de Compostela, } \\
\text { Espanha }\end{array}$ & $\begin{array}{l}\text { francisco.hernandez.rodriguez@ } \\
\text { consellogalegodacompetencia.es }\end{array}$ \\
\hline João Nogueira de Almeida & Universidade de Coimbra, Portugal & jjna@fd.uc.pt \\
\hline Julio Garcia Camiñas & Universidade da Coruña, Espanha & jgc@udc.es \\
\hline Manuel António Pita & $\begin{array}{l}\text { ISCTE - Instituto Universitário de Lisboa, } \\
\text { Portugal }\end{array}$ & manuel.pita@iscte-iul.pt \\
\hline Paulo Nogueira da Costa & Universidade Autónoma de Lisboa, Portugal & pcosta@ual.pt \\
\hline Pedro Trovão do Rosário & Universidade Autónoma de Lisboa, Portugal & prosario@autonoma.pt \\
\hline Roberto Mazzola & $\begin{array}{l}\text { Università degli Studi del Piemonte } \\
\text { Orientale - Amedeo Avogadro, Itália; }\end{array}$ & rmazzola961@gmail.com \\
\hline Teófilo Ârea Leão Júnior & $\begin{array}{l}\text { Università di Torino, Itália } \\
\text { de Marilia, Brasil }\end{array}$ & $\begin{array}{l}\text { Universidade Estadual do Norte do Paraná, } \\
\text { Brasil }\end{array}$ \\
\hline Valter Santin & $\begin{array}{l}\text { ISCTE - Instituto Universitário de Lisboa, } \\
\text { Portugal }\end{array}$ & teofiloleaojr@gmail.com \\
\hline Vasco Branco Guimp.edu.br
\end{tabular}




\section{Índice Index}

6 Editorial Editorial

RUBEN BAHAMONDE

7 Uma segurança interna cada vez mais europeia? Uma segurança externa cada vez mais nacional? An internal security even more european? An external security even more national? ANA MIGUEL DOS SANTOS

Governo das sociedades e compliance em Portugal: um escorço de sua delimitação histórico-normativa Corporate governance and compliance in Portugal: a foreshortening of its historical-normative delimitation

PEDRO TROVÃO DO ROSÁRIO | PAULO ROBERTO BARBOSA RAMOS | DAVID ELIAS CARDOSO CAMARA

46 Papel da Vítima no Direito Português e no Direito Internacional The Role of the Victim in Portuguese Criminal Law and in International Law MARIA JOÃO SIMÕES ESCUDEIRO

61 Oralidad y litigio en América Latina. Principales hallazgos de un estudio empírico Orality and litigation in Latin America. Main findings of an empirical study LEONEL GONZÁLEZ | MARCO FANDIÑO

84 O princípio democrático na União Europeia The democratic principle in the European Union CARLOS C. PROENÇA

101 Principio de proporcionalidad y delitos de peligro abstracto The principle of proportionality and crimes of abstract danger TERESA AGUADO-CORREA

151 Risco, «inimigo" e o direito penal do futuro Risk, "enemy" and the criminal law of the future HERMÍNIO CARLOS SILVA RODRIGUES

\section{RECENSÕES}

REVIEWS

199 PIRES, Alex Sander; ROSÁRIO, Pedro Trovão do; BAHAMONDE, Ruben. (Org.) Compliance: perspectivas e novas dinâmicas. Coimbra: Almedina, 2019. 101 p. ISBN 978-972-40-8268-4. RODRIGO LUÍS ZIEMBOWICZ

203 VALENTE, Manuel Monteiro Guedes (Coord.). Os desafios do direito do século XXI: violência, criminalização, consenso, tutela digital e laboral. Coimbra: Almedina, 2019. 196 p. ISBN 978-97240-8224-0.

EMANUEL CARVALHO

209 VALENTE, Manuel Monteiro Guedes (Coord.) - “Criminalidade Organizada Transnacional”, Corpus Delicti - I, Coimbra: Almedina, 2019. ISBN 978-972-40-8223-3. INÊS FARINHA 


\section{Editorial Editorial}

Continuamos a nossa caminhada com a apresentação deste novo número onde permanecemos fiéis à apresentação de trabalhos de investigação provenientes de investigadores de diversas origens e graus, resultando esta pluralidade da seleção dos trabalhos mais atuais e pertinentes no atual panorama jurídico.

A nossa missão passará em futuras edições por ampliar o leque de línguas utilizadas pela revista permitindo assim incluir na nossa comunidade outros horizontes jurídicos, providenciando de forma mais eficaz não apenas difusão dos conhecimentos nacionais como também dinamizando a integração dos avanços de outros ordenamentos de referência.

Decorridos estes dois anos de consolidação do nosso renascimento, a normal tendência será o abandono da edição dupla da revista, em formato papel e em formato digital, sendo que este será o último número, sem prejuízo de eventuais edições especiais, que será impresso. Neste contexto, a Revista Galileu será de teor exclusivamente digital, de libre acesso e adaptada aos novos paradigmas de difusão do conhecimento científico.

Um muito obrigado para todos os nossos colaboradores e um bem hajam para os leitores!

O Diretor da Galileu

Ruben Bahamonde Delgado 


\title{
Uma segurança interna cada vez mais europeia? Uma segurança externa cada vez mais nacional?
}

\author{
An internal security even more european? \\ An external security even more national?
}

\begin{abstract}
ANA MIGUEL DOS SANTOS
anamiguelsantos@hotmail.com

GALILEU - REVISTA DE DIREITO E ECONOMIA - e-ISSN 2184-1845

Volume XX - $1^{\text {st }}$ July Julho $-31^{\text {TH }}$ December Dezembro $2019 \cdot$ pp. 7-25

DOI: http://doi.org/10.26619/2184-1845.XX.2.1

Submitted on September $4^{\text {th }}, 2019$. Accepted on November 15 ${ }^{\text {th }}, 2019$

Submetido em 4 de setembro, 2019 . Aceite a 15 de Novembro, 2019
\end{abstract}

RESUMO A propensão para uma combinação de política de alianças, a segurança coletiva, o multilateralismo, a relação desequilibrada entre os Estados Unidos e a Europa, a segurança europeia, são alguns dos fatores estruturais que afetam a capacidade de estados únicos, mesmo os mais poderosos, para exercer a liderança no domínio da segurança. Por seu turno, o novo tipo de fenómenos como o terrorismo, a escassez de recursos, catástrofes naturais, pandemias ou movimentos de refugiados em massa, têm vindo a retrair a preeminência da dimensão militar da segurança.

Estas transformações e o significativo robustecimento de responsabilidades por parte da União Europeia por estas matérias de segurança e de defesa, impõem novas formas de cooperação e de liderança no mundo multipolar em que vivemos. O Estado português, enquanto titular da função de soberania de prover segurança, não pode adiar o processo de adequação a estas recentes conceções de segurança e de defesa que, de forma reiterada e gradativa, vêm sustentando uma visão abrangente de segurança, na qual a utilização dos recursos humanos e materiais disponíveis, não dependem da sua natureza - militar ou policial.

No atual ambiente de segurança que vivemos, a divisão clássica entre segurança interna e segurança externa estará em crise? Continua a justificar-se esta visão westfaliana de pensar a segurança, como forma de limitar a atuação da Polícia e das Forças Armadas?

Pretende-se, com este artigo, proceder a uma análise, exploratória, sobre se esta visão, marcadamente bipolar, continua a fazer sentido diante das novas ameaças e do atual contexto internacional. 
ABSTRACT The propensity for a combination of political alliances, collective security, multilateralism, the unbalanced relationship between the United States and Europe, European security, are some of the structural factors that affect the capacity of states, even the most powerful, to lead in the field of security. In turn, the new type of phenomena such as terrorism, resources scarcity, natural disasters, pandemics or mass refugee movements, have been retracting the pre-eminence of the military dimension of security.

These transformations and the significant strengthening of responsibilities by the European Union for these security and defense matters, require new forms of cooperation and leadership in the multipolar world. The Portuguese State, as the holder of the sovereignty function to provide security, can't postpone the process of adaptation to these recent security and defense concepts, which, on a repeated and growing basis, have been supporting a comprehensive security view, in which the employment of human and material resources do not depend on their nature - military or police.

In the current internacional security environment, is the classic division between internal security and external security in crisis? Does this westphalian security view, continue to be justified as a way of limiting the performance of the Police and Armed Forces?

The aim of this article is to conduct an exploratory analysis of whether this markedly bipolar vision continues to make sense regarding the new threats and the international scene.

\section{Introdução}

No mundo globalizado em que vivemos, de forte pendor e (de)pendência tecnológica, pensar a segurança1 deixou de se revelar uma tarefa simples. É um conceito com múltiplas dimensões e em permanente mutação.

Ao longo da última metade do século XX, foram várias as correntes de pensamento que se dedicaram ao estudo deste conceito. $\mathrm{Na}$ área da segurança internacional, por exemplo, o debate permitiu a consolidação de três vertentes teóricas: a tradicionalista, a abrangente e a crítica. A visão tradicionalista, em harmonia com as premissas teóricas realistas, defende

\footnotetext{
1 A palavra segurança tem origem no latim, (se+cura), e significa sem preocupações, e etimologicamente, ocupar-se de si mesmo. É com o Renascimento que a segurança é autonomizada como finalidade da organização política (Hobbes, 1973). No positivismo jurídico, que definia o Estado como detentor do monopólio legal da coação (- a coação no centro do direito), Max Weber (1971), considerou que a coação era o instrumento da segurança e estava excluída do contratualismo puro que era o coração da teoria democrática herdada do séc. XVIII. A Teoria geral do estado alemã autonomizou a segurança como finalidade de um Estado (Caetano,1963).
} 
que a segurança é indissociável da guerra e, por isso, estes estudos devem restringir-se à análise das ameaças do uso e do controlo da força militar, tendo como elemento essencial da sua investigação, o Estado e a integridade do território (Walt, 1991). A vertente abrangente, por conseguinte, propõe que os estudos de segurança devem incorporar tanto as ameaças militares como outras provenientes de áreas como a política, a economia, o ambiente e contexto social (Buzan, 1991). Já a perspetiva mais crítica, associada, por exemplo, aos trabalhos da Escola de Frankfurt ${ }^{2}$, recomenda que os estudos sobre segurança devam colaborar para a emancipação humana, juntamente com outros valores como a igualdade e a liberdade (Booth, 1995).

De uma forma geral, confirma-se uma ausência de consensos no reconhecimento de um significado e conceito comuns. Buzan (1991), por exemplo, considera que a segurança é um underveloped concept, e que, até à década de 80, não foi objeto de qualquer conceptualização ${ }^{3}$, o que, segundo o autor, fundamenta-se na tendência para sobrepor a noção de segurança com a de poder, e, não menos relevante, a falta de interesse dos decisores políticos por esta conceptualização.

Efetivamente, este conceito ainda não mereceu um desenvolvimento teórico semelhante a outros direitos como os de justiça, liberdade, igualdade, representação e poder, como destacou Digeser (1994). No entanto, a urgência de um conceito e a necessidade de consensos são imprescindíveis no debate securitário do século XXI.

Em Portugal, os estudos sobre segurança têm sido historicamente concatenados à sua dimensão mais objetiva, enquanto tarefa fundamental do Estado de prover segurança, em detrimento da sua dimensão mais subjetiva e individual, ou seja, enquanto direito fundamental4

Por seu turno, os estudos e as políticas de segurança em Portugal, na sua dimensão mais objetiva e funcional, têm sido sustentadas por uma divisão westfaliana, entre segurança interna e externa, policial e militar.

O presente artigo, partirá de uma análise retrospetiva sobre a evolução dos estudos de segurança desenvolvidos sobretudo a partir da $2 .^{\mathrm{a}}$ metade do século XX ${ }^{5}$, que Walt (1982)

2 Surge com o Instituto de Pesquisa Social (Institut für Sozialforschung), fundado em 1923, um instituto anexo da Universidade Goethe em Frankfurt, Alemanha.

3 Como ensinou Hempel, a explicação conceitual procura identificar a estrutura lógica das expressões, tirando partido dos significados habituais dos termos. O conceito visa reduzir as limitações, ambiguidades e inconsistências do seu uso comum, propondo uma reinterpretação destinada a aumentar a clareza e precisão dos seus significados, bem como da sua capacidade de funcionar em hipóteses e teorias com força explicativa e preditiva (Hempel, 1952, p. 12).

4 Cfr. artigo $27 .^{\circ}$ da Constituição da República Portuguesa. A doutrina constitucional tem atribuído uma função secundária a este direito à segurança, na medida em que o define como um direito-garantia do exercício dos restantes direitos (Canotilho e Vital Moreira, 2007).

5 Período da história mundial que muitos autores atribuem ao momento em que a União Soviética se dissolve, 26 de dezembro de 1991 (Wolfowitz, 2000). 
intitulou como "the golden age" dos estudos críticos de segurança, procurando assinalar os estudos mais pertinentes em matéria de conceptualização de segurança. De seguida, identificaremos alguns dos fatores e das ameaças que influenciam o cenário de segurança internacional, para melhor compreender a relevância atual dos conceitos de segurança cooperativa e de segurança europeia. Por fim, identificaremos o enquadramento constitucional português ${ }^{6}$ de segurança, sobretudo a partir da primeira revisão constitucional de 1982, que marcou o afastamento dos militares do poder político e das funções de polícia, a que se seguiu uma bipolarização no exercício de funções de segurança: segurança interna versus segurança externa, recentemente mitigada, com a previsão da possibilidade de colaboração das Forças Armadas em missões de segurança interna pela Lei de Segurança Interna aprovada em 20087.

\section{As tentativas de conceptualização de segurança.}

Durante o período da Guerra Fria ${ }^{8}$, as correntes que dominaram os estudos de segurança9

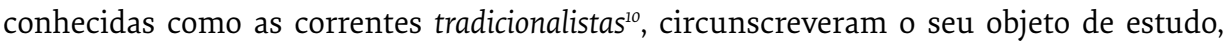
sobretudo, à análise da força militar, uma vez que, para eles, a segurança era indissociável da guerra e do poder político, por isso devia ser definida como o estudo da ameaça, do uso e do controlo da força militar (Walt, 1991). Todavia, é neste contexto que nasce o conceito de dilema de segurança ${ }^{11}$ e o conceito de segurança comum ${ }^{12}$, que tem como objetivo evitar as agressões por meio de instrumentos de alianças, e é enquadrado pelas políticas de balança de poder (Tarzi, 1997). Para os neorrealistas ${ }^{13}$, por exemplo, o conceito de segurança é seme-

6 Constituição da República Portuguesa de 1976.

7 Lei n. ${ }^{\circ} 53 / 2008$, de 29 de agosto.

8 O termo "Guerra Fria" foi usado pela primeira vez em 1947 por Bernard Baruch, senior adviser de Harry Truman, o $33 .^{\circ}$ Presidente dos Estados Unidos, para se referir às crises frequentes entre os Estados Unidos e a ex-União Soviética, não obstante terem lutado lado a lado contra a Alemanha nazista na Segunda Guerra Mundial.

9 Para William (2008), os estudos de segurança são uma área de conhecimento académico relativamente recente e constitui uma invenção anglo-americana ligada ao pós $2 .{ }^{a}$ Guerra Mundial. O realismo, de maneira geral, pensa a segurança em termos de estados, estratégia, ciência, poder e status quo. Existem, porém, outras abordagens, como a de Buzan, que ilustra distintas conceções de segurança, a saber, militar, política, econômica, social e ambiental.

10 Tais como os realistas e os neorrealistas.

11 O conceito dilema de segurança, foi descrito pela primeira vez por Herz (1950).

12 Conceito desenvolvido no Relatório da Comissão Independente para Desarmamento e questões de Segurança de 1982, presidida por Omar Palme, primeiro-ministro sueco. Este conceito de segurança comum assumia uma deslegitimação global do uso da força através da reestruturação e redução do armamento militar e nuclear, a partilha de tecnologia e a adoção de padrões internacionais de direitos humanos, liberdades e garantias.

13 O Termo "Neorrealismo" é utilizado na área das relações internacionais para indicar uma teoria estrutural proposta pelo professor e pesquisador e investigador Kenneth Waltz, em 1979. Segundo este autor, as ações dos Estados podem ser explicadas pelas pressões exercidas sobre eles por uma inata competição internacional, que limita e constrange as suas escolhas. Defende ainda que o mundo existe num estado perpétuo de anarquia internacional, onde não existe fonte de ordem, e a ordem do doméstico, onde reside uma autoridade central - o Estado ou o governo (Waltz, 1979). 
Uma segurança interna cada vez mais europeia? Uma segurança externa cada vez mais nacional?

ANA MIGUEL DOS SANTOS

GALILEU - e-ISSN 2184-1845 - Volume XX - Issue Fascículo $2 \cdot 1^{\text {st }}$ July Julho $-31^{\text {th }}$ December Dezembro $2019 \cdot$ pp. 7-25

lhante ao de campeão. A segurança é o objetivo mais importante de um Estado, e, assim como as equipas competem para serem campeões, os Estados competem por segurança ${ }^{14}$ (Gallie, 1956).

Wolfers (1952), no entanto, apresentou uma visão diferente de segurança. Para este Professor norte-americano, a política internacional não é um jogo onde os Estados competem no mesmo campeonato e dentro das mesmas regras, é muito mais do que isso. Por isso, caracterizou as dimensões objetivas e subjetivas de segurança. Na sua dimensão objetiva, aos Estados era possível superestimarem ou subestimarem a probabilidade real de ocorrência de danos aos valores adquiridos. No primeiro caso, um objetivo da política de segurança pode ser a redução de medos injustificados, ao passo que, na segunda hipótese, um Estado pode considerar-se como seguro, mesmo quando não o é. Na sua dimensão subjetiva, segurança pode ser designada como a peace of mind ou the absence of fear, pois são valores que, segundo o Autor, podem ser especificados, mas nunca em termos de defesa de vital interests ou de core values, na medida em que compromete o valor da segurança como um objetivo político, que deve ser comparado com outros objetivos. Daí que Wolfers entenda que a segurança é um valor que cada Estado tem em maior ou menor grau, e que pode aspirar a vir a ter outros patamares de maior ou menor intensidade.

Buzan (1983), no entanto, alerta para que, se a segurança for definida por uma questão de grau, então mais complexa será a definição do mínimo de segurança. Também por isso, daí decorre a elevada importância da conceptualização do termo segurança, desde logo para auxiliar os Estados na tarefa de alocação de recursos entre os fins concorrentes (Simon, 1976). Num mundo em que os bens e os meios são cada vez mais escassos e que devem ser canalizados para objetivos cada vez mais concorrentes, (nenhum dos quais completamente alcançável), impõe-se a seguinte questão, How much is enough?

Na pré-história, por exemplo, as pessoas podem ter vivido em cavernas para se protegerem e sentirem em segurança, mas não permaneceram lá, para sempre. Cada vez que arriscaram a sua segurança em busca de comida, água ou descoberta, demonstravam vontade de sacrificar a segurança da caverna por algo que, presumivelmente, valorizavam mais. Do mesmo modo, os Estados modernos não afetam todos os seus recursos em busca de segurança, mesmo em tempo de guerra. Até as sociedades mais sitiadas e vulneráveis canalizam alguns dos seus recursos para fornecer comida, roupas e abrigo às suas populações.

Hobbes (1651), no seu livro Leviatã, uma das obras de referência do realismo clássico, considerava que a forma de determinar o valor da segurança seria através da pergunta: como seria a nossa vida sem ela? Para este autor, a vida, sem segurança, seria "solitária, pobre, 
desagradável, brutal e curta". Este raciocínio levou muitos estudiosos, durante longo tempo, a afirmar o "primado" do objetivo da segurança, colocando-a como um pré-requisito para o gozo de outros valores como a liberdade, a prosperidade, entre outros. Mas tal raciocínio, como defendeu Baldwin (1997), 3 séculos volvidos, poderá ser feito com outros bens essenciais, pois o valor de algo não depende da qualidade inerente do bem em si, mas também do resultado de condições sociais externas - oferta e demanda. Daí que, quanto maior for o nível de segurança, menor será o encargo para o seu incremento. É por isso que Baldwin (1997) concorda com Wolfers (1952): a segurança poderá ser especificada de diversas formas. Em relação aos seus atores, tendo em conta os valores a garantir, o grau de segurança, os tipos de ameaças, os meios para lidar com tais ameaças, os custos e o período de tempo relevantes para a sua execução.

Tendo presentes estes fatores e o seu grau de mutabilidade, Wolfers (1952) acabou por definir segurança como a ausência de ameaças aos valores adquiridos.

Esta definição de Wolfers (1952) revelava uma novidade diante das correntes tradicionais realistas, na medida em que não cingia a análise da segurança às questões militares e nem a centrava nos Estados. Como defendeu Ullman (1983), esta definição veio permitir a inclusão de fenómenos como os terramotos no tipo de ameaças ${ }^{15}$ à segurança, compelindo os Estados a conceberem respostas diferentes daquelas que tradicionalmente utilizavam numa situação de ataque militar. Com efeito, aos ataques militares, os Estados podem adotar políticas de dissuasão, com o objetivo de fornecer segurança e de reduzir a probabilidade de que o ataque ocorra. Pelo contrário, na resposta a um terramoto, os Estados adotam building codes, ou seja, um conjunto de regras-padrão que, não evitam a sua ocorrência, mas ajudam a diminuir os danos aos acquired values.

O modelo conceptual de segurança descrito por Wolfers (1952), foi e continua a ser muito relevante no quadro geral dos estudos de segurança. Baldwin (1997) chegou mesmo a defender que a análise conceptual de segurança começou e terminou com esta definição de Wolfers, para além dos consensos que reuniu no meio académico durante grande parte da $2 .^{\text {a }}$ metade do século XX.

Se os primeiros passos na tentativa de conceptualização de segurança foram dados no período da Guerra-Fria, com especial destaque para os estudos norte-americanos neste devir conceptual, o certo é que o seu desenvolvimento e maturação acabaram por ganhar um novo folego com o contributo que a Europa passou a representar nos estudos de segurança (Buzan, 1991), que eram muito críticos das teorias tradicionalistas. São exemplo, a Escola de Copenhaga, a Escola da Paris e a Escola de Aberystwyth. 
A Escola Aberystwyth, reconhecida pela sua forte agenda política, não obstante defender o conceito de segurança pode ser definido como a ausência de ameaça, considera que o indivíduo é o principal referencial de segurança e não os Estados, que não conseguem garantir a segurança de forma estável, e são demasiado heterogéneos para alcançar uma teoria consensual (Buzan, 1991). É com esta Escola que surge um conceito essencial: segurança individual (Booth, 2004). Por seu turno, a Escola de Copenhaga defendia que o conceito de segurança deveria incluir sectores como o ambiental, económico ou social, e que a segurança emerge como uma força política e prática discursiva que faz algo, ou seja, para esta Escola, uma questão sobre segurança resulta sempre de uma decisão política (Buzan, 2010). É precisamente sobre esta politização do conceito segurança que surgem as principais críticas a esta corrente, que a qualificam como demasiado objetivista e estatocêntrica (McSweeney $(1996,1998)$. A Escola de Paris, inspirada nos estudos de Pierre Bourdieu, Didier Bigo e Jef Huysmans, concentrou a sua análise no estudo das formas de dominação dos Estados e das formas de articulação das relações de força e poder. Os Autores desta Escola rejeitam a ideia de que a segurança interna e segurança externa são campos distintos da segurança e consideram-na uma ficção (Bigo, 2000) e (Campbell, 1998).

Na verdade, a segurança pode ser avaliada por muitos atores, indivíduos, famílias, Estados e outros, não sendo, em si mesma, a vertente militar a única que a qualifica. Diante da pluralidade e diversidade das ameaças à seguranç $\mathrm{a}^{16}$, diversos são os meios que podem e devem ser utilizados para a alcançar, e que não se esgotam apenas no excessivo centralismo do uso e controlo da força militar, como apontam as tendências dos estudos recentes, no contexto das relações internacionais.

\section{O clima de segurança}

O fim do período da Guerra-Fria é, indiscutivelmente, um dos períodos mais marcantes da agenda da segurança internacional desde o fim da Segunda Guerra Mundial e do início da era nuclear, marcando um novo começo.

O desaparecimento da bipolaridade sistémica obrigou à revisão da agenda para os direitos humanos, da paz internacional, da cooperação e da estabilidade. O fim da Guerra Fria desencadeou o surgimento de novas ameaças e desafios para a segurança internacional, e o avanço da globalização levou à redistribuição de poderes no sistema internacional

16 BUZAN (1983), distinguia entre ameaças militares (apreensão de território, invasão, ocupação, mudança de governo, manipulação de políticas), ameaças económicas (exportação práticas, restrições de importações, manipulações de preços, inadimplência na dívida, controle de moeda) e ameaças ecológicas (danificando a base física do estado). 
Uma segurança interna cada vez mais europeia? Uma segurança externa cada vez mais nacional?

ANA MIGUEL DOS SANTOS

GALILEU - e-ISSN 2184-1845 - Volume XX - Issue Fascículo $2 \cdot 1^{\text {st }}$ July Julho - 31 th December Dezembro $2019 \cdot$ pp. 7-25

(Baylis, 2007). Com a globalização, a capacidade de intervenção dos Estados e as relações Estado-Estado mudaram drasticamente (Strange, 2002). As guerras clássicas foram gradualmente transformadas em "guerras modernas" (Shaw, 2005 e Smith, 2006).

Neste período, os desafios aumentaram e o mundo tornou-se mais perigoso, devido à multiplicidade de atores na cena internacional e à mudança de perceção da força militar, da guerra e da segurança.

O surgimento da energia nuclear, o colapso da URSS, a substituição da bipolaridade do mundo da Guerra Fria por um mundo multipolar ${ }^{17}$, a emergência de novas potências económicas asiáticas e a proliferação de armas nucleares e biológicas em países como Irão, Israel e Iraque, alteraram a ordem mundial e desafiaram a estabilidade do princípio da dissuasão nuclear, garantido e sustentado pela política de blocos e pelo equilíbrio das duas super potencias, durante a Guerra Fria (Hammes, 2006). Por seu turno, o terrorismo e o surgimento de atores sub-estaduais (Smith, 2006), como a Al Qaeda e o Hamas, tornaram-se uma nova fonte de ameaça à segurança, devido à sua elevada capacidade de operarem internacionalmente (Shaw, 2005).

Neste contexto, Baldwin (1995), considera que o final do período da Guerra Fria se caracterizou pela apreciável diminuição da importância do poder militar em termos de política internacional, não apenas porque as ameaças militares são menos prevalentes, mas ainda porque a força militar é menos útil como ferramenta do Estado. Por essa razão, observa o autor, que deverá ser reexaminada a forma como pensamos as relações internacionais e a segurança nacional, que necessita de uma visão mais ampla do seu conceito de forma a incluir problemas domésticos na national security agenda, ou ainda tratar ameaças externas não-militares, como questões domésticas.

Com a globalização, o foco passou a incidir sobre a análise da capacidade do Estado em observar a segurança humana e os direitos humanos. No contexto de um mundo com fronteiras cada vez mais diluídas, em virtude dos acordos internacionais celebrados entre Estados, a agenda internacional dos direitos humanos é, inevitavelmente, reaberta e representada também por um conjunto de atores não-estatais, provenientes da sociedade civil global, designadamente organizações internacionais não governamentais (ONG's) (Boutros-Ghali, 1992).

Como salientou Mary Kaldor (1999), no pós-Guerra Fria assistiu-se ao surgimento das guerras modernas, que carecem de tempo e de espaço, porque se baseiam em demandas não quantificáveis, muitas vezes relacionadas com ideologias, etnias, religiões e a própria cons-

17 Terminologia utilizada para demonstrar que a centralidade do poder já não está claramente identificada. 
trução social da história. As velhas guerras foram substituídas por novos tipos de ameaças e conflitos, como o crime organizado e as guerras religiosas e civis (Kaldor, 1999).

A crescente presença de non-state actors $^{18}$, coloca novos desafios para as perceções clássicas de segurança, por meio de variáveis não tangíveis, como a perceção, contrariamente às antigas ambições militares relacionadas com a invasão territorial e as vantagens económicas.

Para enfrentar estes novos desafios da segurança, a comunidade internacional teve que elaborar uma nova agenda na era do pós-Guerra Fria. A intervenção humanitária, a segurança dos estrangeiros (Jackson, 2003), as intervenções autorizadas pelo Conselho de Segurança da ONU na década de $1990^{19}$, seguindo, por exemplo, as operações na República Democrática do Congo em 1996 e no Kosovo em 1999 (Baylis, 2007), a imposição de sanções económicas, com o objetivo de exercer pressão política, em vez de militar, sobre Estados e comunidades em desequilíbrio, denotam uma tendência de passagem de uma noção de segurança centrada no Estado para uma segurança humana ${ }^{20}$, centrada no indivíduo, na qual a dimensão humana extravasa a dimensão territorial da ameaça (Kerr, 2006).

A agenda do pós-Guerra Fria para a paz envolveu também a reorganização das forças militares, onde o desvio ao conceito clauswitziano ${ }^{21}$ de guerra foi óbvio na tentativa de melhorar e conter ${ }^{22}$, em vez de destruir ou, simplesmente, conquistar (Smith, 2006). Além disso, o papel da sociedade civil global e a crescente influência das ONG's como defensores da paz e dos direitos humanos, e formuladores de políticas globais, merecem atenção e destaque.

18 Clapham (2009), define atores non-state actors (atores não-estatais) como todas as entidades diferentes dos Estados.

19 Exemplo, as operações na República Democrática do Congo em 1996 e no Kosovo em 1999.

20 O conceito de "segurança humana", surgido nos anos 1990, alarga a noção tradicional de segurança, antes centrada na segurança dos Estados. O valor fundamental é, agora, o próprio indivíduo. A segurança humana visa, pois, proteger os indivíduos contra ameaças como a pobreza, a fome, a doença, a criminalidade, as catástrofes naturais, as violações dos direitos humanos, a arbitrariedade, a violência sexual, a imigração, as deslocações internas, o tráfico de pessoas ou o desemprego. "Segurança de emprego, segurança de rendimento, segurança da saúde, segurança do ambiente, segurança face à criminalidade, são as formas que assume a problemática da segurança humana", explica o Programa das Nações Unidas para o Desenvolvimento (PNUD), no seu relatório anual sobre desenvolvimento humano de 1994. BAN KI-MOON, 8. ${ }^{\circ}$ Secretário-Geral da ONU, entre 2007 e 2017 , no seu discurso na Conferência de Tóquio sobre Segurança, sublinhou a necessidade de promover o conceito de segurança humana, que coloca o indivíduo no centro das prioridades e da ação da ONU. "Mais do que nunca vivemos num mundo interligado. As crises atuais ameaçam as vidas de milhões de homens, mulheres e crianças. Aumentam a insegurança humana e comprometem os avanços rumo à realização dos Objetivos de Desenvolvimento do Milénio (ODM). Todos têm o direito de viver em liberdade, sem sentir medo, e de poder viver livres e com dignidade. Estas aspirações estão no centro da segurança humana e da nossa missão de construir um mundo melhor para todos." (www.onu.com).

21 Carl Phillip Gottlieb von Clausewitz, General Prussiano, nascido a 1 de junho de 1780, é considerado um grande estrategista militar e teórico da guerra com a obra, Da Guerra (Vom Kriege) (1976). Ficou conhecida a frase em que Clausewitz associa guerra e política: "A guerra é a continuação da política por outros meios".

22 Exemplos de guerras de contenção são os conflitos no Iraque e no Afeganistão. 
Não menos relevante, e mais recentemente, os eventos do 11 de setembro de $2001^{23} \mathrm{e}$ a utilização de meios civis, dentro do território de um país ocidental, vieram marcar de forma irreversível a agenda para a segurança. O terrorismo passou a ser uma realidade à escala global.

Como resposta, foi necessário proceder à introdução e aplicação de medidas de segurança em todos os aspetos do dia a dia do cidadão comum. Detetores de metais protegem as entradas das escolas, agentes de segurança andam a bordo de aviões, as tropas dispersam-se pelo mundo procurando um inimigo que não reside num lugar, antes numa crença ou ideologia.

Como se combate uma crença ou uma ideologia?

Em resposta à tragédia do 11 de setembro, o Congresso dos EUA aprovou em 25 de novembro de 2002, a The Homeland Security Act $^{24}$, uma lei de segurança interna que procurava combinar esforços, autoridades e poderes de mais de vinte agências federais ${ }^{25}$ numa única entidade que a responsabilidade pela segurança dos cidadãos americanos e das fronteiras. As atividades diárias dos cidadãos passaram a ser vigiadas pelo governo, as conversas privadas deixaram de o ser, os registos de bibliotecas, os dados de origem étnica e, até mesmo a cor favorita de uma pessoa, passaram a ser vigiados ${ }^{26}$. Em nome da segurança, todos os americanos sacrificaram as suas liberdades individuais.

No entanto, não tardou a contestação a esta lei de segurança interna. Os grupos de liberdades civis referiam-se a esta Patriotic Act como uma lei de consequências não desejadas. Em 16 de janeiro de 2003, o Senador Russ Feingold liderou um processo de análise das questões de privacidade dos cidadãos dos Estados Unidos, que temiam abusos e violações de direitos constitucionais básicos, e que culminou na aprovação do "The Terrorism Information Awareness Program" 27.

À medida que o choque decorrente do ataque terrorista do 11 de setembro se dissipava, e os americanos, mais especificamente os departamentos governamentais do Estado, come-

23 Na história dos Estados Unidos, não existia uma agressão estrangeira às fronteiras do país desde o ataque a Pearl Harbor, e sobretudo com a utilização de meios civis.

24 Homeland Security Act of 2002, Public Law 107-296.

25 Entre as agências incluídas estão the Federal Emergency Management Agency, the U.S. Secret Service, the U.S. Customs Service, the U.S. Coast Guard, the Immigration and Naturalization Service.

26 Vide in, www.uscis.gov.

27 Aprovado pelo Congresso em maio de 2013, este Programa de Sensibilização para a Informação do Terrorismo, mais tarde renomeado para The Terrorism Information Awareness (TIA), baseava-se num conceito de predictive policing, de recolha de informação detalhada dos indivíduos para antecipar e prevenir crimes, como parte dos esforços para conquistar esta guerra contra o terror. O programa procurou todo o tipo de informações pessoais na busca de terroristas em todo o mundo. De acordo com o senador Ron Wyden, o TIA foi o maior programa de vigilância da história dos Estados Unidos (vide in, http://usatoday30.usatoday.com/news/washington/2003-09-25-pentagon-office_x.htm). 
çavam a compreender a realidade da situação global, uma nova arquitetura da informação antiterrorista surgia no seio das agências de segurança, e o uso de um software de agregação de dados e outras tecnologias avançadas passaram a ser utilizadas, não obstante as contestações permanentes ${ }^{28}$.

Porém, cerca de duas décadas volvidas, a situação pouco ou nada mudou. Os ataques terroristas prosseguiram com a utilização de meios civis: 11 de março de 2004 em Madrid, 7 de julho de 2005 no metropolitano de Londres, 15 de novembro de 2015 numa sala de espetáculos em Paris, 22 de março de 2016 em Bruxelas, entre outros. Os Estados Unidos e outros países que vêm enfrentando este problema, não estão em guerra com um lugar ou com um país. Eles estão em guerra com uma ideologia, com uma crença ${ }^{29}$.

As ameaças e os desafios mantêm-se e as lutas contra o terrorismo continuam ainda, nomeadamente, quanto ao mais recente grupo conhecido como ISIS (Islamic State in Iraq and the Levant (Isis) $)^{30}$. Os cidadãos comuns não estão seguros e continuam limitados no seu dia a dia. As viagens de metro, de autocarro, passeios de rua, passaram a estar largamente condicionados e vigiados. Daí que haja, por exemplo, cada vez mais americanos a favor do uso da tortura, como método para obter informações de suspeitos de terrorismo, bem como de medidas de maior escrutínio e seleção, para pessoas oriundas do Médio Oriente.

Os eventos do 9/11 já fazem parte da história americana, e o terrorismo, por seu turno, já faz parte da história global recente.

\section{A Segurança cooperativa e a Segurança europeia}

O fim da Segunda Guerra Mundial marcou definitivamente a agenda da segurança e a perceção do conceito de segurança internacional, especialmente com a criação da Organização das Nações Unidas a 24 de outubro de 1945, que veio substituir a ineficaz e fracassada Sociedade das Nações ${ }^{31}$, por não ter conseguido impedir o eclodir da Segunda Guerra Mundial, para garantir a paz e servir de fórum na resolução de conflitos entre as nações.

28 Electronic Privacy Information Center, (www.epic.org), USA Patriot Act.

29 Para mais desenvolvimentos sobre a segurança religiosa, Shani, 2016.

30 Organização formada em abril de 2013, a partir da Al-Qaeda no Iraque (AQI), tornou-se um dos principais grupos jihadistas a lutar contra forças do governo na Síria e no Iraque. Não existem dados concretos sobre a sua dimensão efetiva, mas está pensada para incluir milhares de lutadores, incluindo muitos jihadistas estrangeiros (http://www. bbc.com/news/world-middle-east-24179084).

31 Organização internacional, idealizada pelas potências vencedoras da Primeira Guerra Mundial quando se reuniram para assinar um acordo de paz, e formalmente constituída com a assinatura do Tratado de Versalhes a 28 de junho de 1919 por 44 Estados, com sede em Genebra, na Suíça. Extinta em 1942, na sequência do desencadear da Segunda Guerra Mundial, esta organização apresentou-se como um fórum internacional para a resolução pacífica de disputas entre Estados com o principal objetivo de manter a paz e evitar a guerra. 
A Carta das Nações Unidas ${ }^{32}$, fortemente influenciada pela visão comum do presidente dos EUA, Franklin D. Roosevelt, e do primeiro-ministro britânico, Winston Churchill, enfatiza a paz, a segurança, o direito internacional, o desenvolvimento económico dos povos e os direitos humanos ${ }^{33}$, como forma de evitar a guerra (Goodby, 1996).

Paralelamente, os Estados foram desenvolvendo alianças militares como forma de responder a esta nova ordem mundial. A OTAN (Organização do Tratado do Atlântico Norte) ${ }^{34} \mathrm{e}$ o Pacto de Varsóvia ${ }^{35}$ foram duas organizações militares de defesa comum, que tiveram um papel fundamental no decurso da Guerra Fria, enquanto alianças que asseguravam a bipolaridade e a política de blocos, decorrentes do fim da Segunda Guerra Mundial. Ainda que estas organizações não se tenham enfrentado em conflitos militares diretos, alimentaram múltiplas guerras em várias zonas do globo, e foram a causa de perigosas desconfianças e receios, devido à implícita ameaça de guerra que tais organizações representavam.

Com o desmembramento da União Soviética e o fim do Pacto de Varsóvia em 1991, o papel da OTAN teve de ser revisto, dado que o principal objetivo para a sua constituição foi ultrapassado ${ }^{36}$. A OTAN tem vindo a reformular a sua estratégia e o seu foco principal passou a ser a proteção dos seus aliados da Europa e da América do Norte. Abriram-se as portas para a entrada de países do Leste da Europa, a Hungria, a Polónia e a República Checa, em 1999, a Bulgária, Eslovénia, Eslováquia, Estónia, Letónia, Lituânia e Roménia,

32 A Carta das Nações Unidas é o documento formal que concretiza o acordo na criação da ONU. De acordo com o preâmbulo da Carta, os países estavam determinados em salvar as gerações sucessivas do flagelo da guerra, em reafirmar a fé nos direitos humanos fundamentais, na dignidade e no valor da pessoa humana, na promoção da igualdade de direitos dos homens e das mulheres e das nações grandes e pequenas, estabelecer condições em que a justiça e o respeito das obrigações decorrentes de tratados e outras fontes de direito internacional possam ser mantidos, na promoção do progresso social e de melhores padrões de vida e na liberdade.

33 A visão de Roosevelt e de Churchill surgiu na sua primeira declaração conjunta a 14 de agosto de 1941, após uma reunião na Terra Nova, que ficou conhecida como a Carta do Atlântico. Esta declaração forneceu uma declaração ampla dos objetivos de guerra dos EUA e da Inglaterra, estabelecendo os princípios comuns nas políticas nacionais dos respetivos países: Estes países não procuram nenhum engrandecimento, territorial ou outro; não pretendem ver mudanças territoriais que sejam desejadas pelos povos; respeito pelo direito de todos os povos de escolher a forma de governo sob a qual viverão; reposição dos direitos soberanos e do governo próprio restaurados para aqueles que foram privados de sua força; promoção da igualdade de condições de acesso ao comércio e às matérias-primas e à prosperidade económica e maior colaboração entre os Estados; promoção de habitação em segurança e liberdade; Sétimo, tal paz deve permitir que todos os homens atravessem o alto mar e os oceanos sem obstáculos; a paz, o desarmamento das nações e o abandono do uso da força (http://www. un.org/en/sections/history-united-nations-charter/1941-atlantic-charter/index.html).res. A Carta do Atlântico que pugnou pela resolução pacífica de disputas entre Estados, sem recurso ao uso da força, considerava que as relações internacionais pós-guerra seriam cooperativas, tornou-se eventualmente numa base para a redação da Carta das Nações Unidas.

34 Constituída a 4 de abril de 1949, pela Bélgica, Canadá, Dinamarca, Estados Unidos da América, França, Islândia, Itália, Luxemburgo, Noruega, Países Baixos, Portugal e Reino Unido.

35 Criado em 14 de maio de 1955, constituiu um compromisso de aliança militar formada por oito países do Leste Europeu: Albânia, Bulgária, Checoslováquia, Hungria, Polônia, Romênia, URSS e República Democrática Alemã.

36 Cfr. www.nato.int 
em 2004. Em 2009, a Albânia e a Croácia integraram esta aliança, e, mais recentemente, em 2017, Montenegro ${ }^{37}$.

Os Estados reconheceram a necessidade de se unirem e organizarem a sua segurança em conjunto, surgindo diferentes tipos de alianças sustentadas em diferentes percepções de segurança, como a segurança comum (Knudsen, 2001) ou a segurança coletiva (Goodby, 1996).

É com o final do período da Guerra Fria, que o conceito de segurança se expande para uma ideia de segurança cooperativa (Knudsen, 2001). Como Carter, Perry e Steinbruner (1992) frisaram, a segurança cooperativa modificou o objetivo das intervenções securitárias, deixando de ser apenas a extinção da violência para passar a abranger também a sua prevenção. A segurança cooperativa consubstancia uma "delegação de competências" dos Estados em organizações que agregam outros Estados e, consequentemente, outras soberanias. Neste quadro, os Estados deixam de ser os principais agentes produtores de segurança, passando esta a ser discutida em fóruns mais alargados, multiculturais, com diferentes percepções de segurança e de direitos, mas com menor número de interlocutores, como é o caso da ONU ou da OTAN.

No entanto, a arquitetura da segurança mundial enfrenta um novo desafio: o reforço da política externa e da política de segurança comum pela União Europeia decorrente do Tratado de Lisboa ${ }^{38}$, faz emergir um novo e relevante ator da política internacional em matérias de segurança.

O Tratado de Lisboa veio reforçar o caminho de uma política europeia vocacionada para a resolução de conflitos e para a promoção do entendimento internacional. De uma abordagem essencialmente económica, avançou-se, assim, para a cooperação política, em termos de política externa e de segurança e defesa comuns ${ }^{39}$. É criada a figura do Alto Representante para as Relações Externas que, passa a ser responsável pela representação externa do bloco e pela assinatura de acordos com países terceiros e organizações internacionais, conferindo, assim, maior unidade e estabilidade à sua ação externa (Teixeira, 2008), que, em matéria de defesa coletiva, continua a respeitar a primazia da OTAN $^{40}$ (Angelet e Vrailas, 2008).

\section{Cfr. www.nato.int}

38 O Tratado de Lisboa foi assinado a 13 de dezembro de 2007 pelos Estados-membros da União Europeia. Veio produzir uma reformulação no funcionamento da União, tornou a Carta da União em matéria de direitos humanos vinculativa, e, com relevo para o presente trabalho, criou o Alto Representante da União para os Negócios Estrangeiros e a Política de Segurança (cfr. www.europa.eu).

39 Cfr. Artigo $13 .{ }^{\circ}$ do Tratado de Lisboa e artigo $26 .{ }^{\circ}$ do Tratado da União Europeia (cfr. www.europa.eu).

40 Cfr. artigo $28 .^{\circ}$-A do Tratado de Lisboa. 
A segurança europeia, ou como Hermenegildo (2018) classificou recentemente, a segurança interna da União Europeia, representa, cada vez mais, um dos objetivos nucleares da ação política da União, que tem vindo a aprofundar mecanismos de resposta conjunta aos fenómenos de criminalidade organizada e de terrorismo que colocam em causa a segurança dos seus cidadãos.

\section{A Segurança na Constituição da República Portuguesa}

"Todos têm direito à liberdade e segurança (...)" ${ }^{41}$. Esta é a formulação utilizada na Constituição Portuguesa, no capítulo dos direitos fundamentais, inspirada na Convenção Europeia dos Direitos do Homem, que tem conduzido, por parte da doutrina, à afirmação de uma relação umbilical de dependência/garantia entre estes direitos - liberdade e segurança -, e também já conceptualizada nas primeiras constituições liberais (Canotilho e Moreira, 2007).

Na doutrina constitucional, o direito à segurança é definido como um direito-garantia de outros direitos fundamentais. Canotilho e Moreira, (2007), definem segurança como a garantia de exercício seguro e tranquilo dos direitos, liberto de ameaças e agressões. A segurança mais como uma garantia de direitos do que um direito autónomo, que deverá ser sempre associada à liberdade ${ }^{42}$. (Pereira, 2012).

Nesta perspetiva, a segurança tem sido entendida como um direito de todos os homens e a sua promoção é tarefa fundamental de uma sociedade organizada em Estado, que, de acordo com a Constituição da República Portuguesa de 1976, concretamente nas duas primeiras alíneas do seu artigo $9 .^{\circ}$, lhe atribui a tarefa de garantia da independência nacional bem como a garantia dos direitos e liberdades fundamentais ${ }^{43}$, a delegar nos seus órgãos (Canotilho e Moreira, 2007), no caso à polícia e às forças armadas.

É um facto singular e relevante que a democracia portuguesa é o único regime político ocidental cuja origem mais recente está num golpe de Estado militar, e que é, ao mesmo tempo um regime pós-autoritário e pós-revolucionário. (Gaspar, 1990).

Todo o processo de fundação do poder democrático em Portugal, decorrente da revolta militar, culminou na aprovação da Constituição de 1976, e encontrou na sua primeira revi-

41 Artigo $27 .^{\circ}$, n. $^{\circ} 1$ da Constituição da República Portuguesa (“CRP”).

42 Para estes autores, (2007), existe uma dimensão positiva e uma dimensão negativa deste direito, sendo que a dimensão positiva deste direito à segurança se traduz num direito positivo à proteção através dos poderes públicos contra as agressões ou ameaças de outrem, e a dimensão negativa deste direito, estritamente associada ao direito à liberdade, traduzindo-se num direito subjetivo à segurança.

43 Artigo 9. ${ }^{\circ}$, alínea b) da CRP. 
são de $1982^{44}$, o momento que marcou o afastamento dos militares da vida e do poder políticos, e o fim do movimento revolucionário. (Canotilho, 2003).

Com a revisão constitucional de 1982, é introduzida a expressão "segurança interna" na lei soberana - artigo $272 .^{\circ}$ da Constituição. Surge como uma das funções a desempenhar pela polícia, integrada no Capítulo da Administração Pública, para além das funções de defesa da legalidade democrática e de defesa dos direitos dos cidadãos, que já constava da versão originária de 1976.

Simultaneamente, e por ocasião do fim do processo revolucionário, reformulou-se o título da constituição, anteriormente denominado por Forças Armadas, o Título X, e alterou-se para uma nova epígrafe: Defesa Nacional, título IX. Com a integração das Forças Armadas neste amplo conceito de defesa nacional, as funções de garantia, do respeito das instituições democráticas, a independência nacional, a integridade do território e a liberdade e a segurança das populações contra qualquer agressão ou ameaça externas, passaram a ser parte integrante deste conceito dirigido pelo Governo, reservando-se às Forças Armadas a função de defesa militar da República ${ }^{4546}$.

Para Valente (2013), a revisão constitucional de 1982 resulta na “(...) constitucionalização da função de polícia que tem como «função defender a legalidade democrática e os direitos dos cidadãos», cabendo-lhe a «prevenção dos crimes, incluindo a dos crimes contra a segurança do Estado», sempre em obediência à Constituição e à legalidade democrática e nunca em obediência ao Governo como se consagrava nos tempos passados, e na restrição das Forças Armadas à «missão específica de defesa da soberania nacional (...)". Por seu turno, defende ainda o referido autor que, a Revisão Constitucional de 1982 serviu ainda para reforçar o processo constitucional de desmilitarização da função de segurança interna - agora função constitucional da Polícia -, e que a intervenção das Forças Armadas apenas se pode verificar em duas situações: no âmbito do estado de sítio e do estado de emergência, sob o comando do Chefe do Estado-Maior-General das Forças Armadas.

Mas, apesar da consagração da expressão segurança interna na constituição portuguesa, tal não correspondeu a uma necessária densificação ou a uma concretização deste

44 Aprovada pela Lei Constitucional n. ${ }^{\circ} 1 / 82$, de 30 de setembro.

45 Redação dada pela revisão constitucional de 1982 ao artigo $272 .^{\circ}$ da CRP.

46 Como destaca Canotilho (1984), as Forças Armadas obedecem aos órgãos de soberania competentes, nos termos da Constituição e da Lei. Esta vinculação assume relevância decisiva para o controlo da legalidade dos atos das autoridades militares, acabando por reconhecer que o ordenamento militar está incorporado no ordenamento constitucional do Estado, segue-se que os princípios constitutivos deste último têm de servir de parâmetro material à disciplina jurídica das Forças Armadas. 
conceito, tendo sido remetido o seu desenvolvimento para uma lei a discutir e a aprovar pela Assembleia da República - a lei de segurança interna ${ }^{47}$.

A versão original da lei de segurança interna aprovada em 1987, manteve o afastamento das forças armadas em questões de segurança interna. Com efeito, a dicotomia segurança interna versus segurança externa, que ganhou expressão e desenvolvimento doutrinário a partir da revisão constitucional de 1982, tem servido como fundamento e limite para a atribuição das missões à polícia e aos militares.

Mas esta conceção dual e estanque de segurança, que se difundiu a partir de 1982, tem vindo a enfraquecer. Quase três décadas volvidas, em 2008, o legislador foi sensível às mudanças que ocorreram na conjuntura que esteve na base da criação da primeira lei de segurança interna em $1987^{48}$, e veio permitir a colaboração das Forças Armadas em matéria de segurança interna nos termos da Constituição e da lei, competindo ao Secretário-Geral do Sistema de Segurança Interna e ao Chefe do Estado-Maior-General das Forças Armadas assegurarem entre si a articulação operacional ${ }^{49}$. Por seu turno, também a lei de defesa nacional, na sua versão de 2009 , introduziu uma norma sob a epígrafe Forças de segurança, para prever a possibilidade de colaboração das forças de segurança colaboram em matéria de defesa nacional nos termos da Constituição e da lei.

\section{Conclusão}

Esta territorialização do conceito de segurança, interna versus externa, como padrão funcional dos órgãos do Estado produtores de segurança, está em crise e merece discussão. A colaboração, cooperação e articulação, em matéria de segurança, interna ou externa, nacional ou europeia, são determinantes e não podem continuar a ser ignoradas.

O tipo de ameaças, a permanente alteração dos sujeitos internacionais, a evolução tecnológica, não se compadecem com visões estanques de um fenómeno que está em permanente mutação nas sociedades hodiernas.

Por seu turno, a alteração do objeto referencial da segurança e a integração de novos sujeitos e a abertura a novos fenómenos que não apenas do foro militar, que resultaram do contributo dos estudos críticos de segurança que emergiram sobretudo com o termo do período da Guerra Fria, colocam novos desafios à conceptualização da segurança.

47 A primeira versão da Lei de segurança interna foi aprovada pela Lei n. ${ }^{\circ}$ 20/87, de 12 de junho, e profundamente alterada em 2008 pela Lei n. ${ }^{\circ}$ 53/2008, de 29 de agosto, atualmente em vigor e objeto de três alterações.

48 Vide in, Parecer da Comissão de Assuntos Constitucionais, Direitos, Liberdades e Garantias e nota técnica elaborada pelos serviços de apoio, publicado no Diário da Assembleia da República de 19 de abril, n. ${ }^{\circ} 83$.

49 Cfr. Artigo $35 .^{\circ}$ da Lei de Segurança Interna, aprovada pela Lei n. ${ }^{\circ}$ 53/2008, de 29 de agosto. 
Assim, e em face do atual contexto internacional, fará sentido continuar a utilizar esta dicotomia segurança interna versus segurança externa, como forma de condicionar o Estado no momento de afetação dos seus recursos?

A natureza das ameaças, a dependência externa em matéria de segurança e defesa do Estado, convocam a alteração de um paradigma que, de forma paulatina, foi entrincheirando este conceito de segurança numa divisão que, por um lado, contende com as tendências doutrinárias recentes de conceptualização deste fenómeno e, por outro lado, está em manifesto contraciclo com as instituições internacionais de que Portugal faz parte.

O Estado, enquanto organização política democrática, é o titular originário da tarefa fundamental de garantia da segurança e de proteção dos direitos dos cidadãos que deve exercer através dos seus órgãos de soberania, in casu, o Governo. Por essa razão, a afetação dos recursos em matéria de segurança, deverá resultar de uma análise una e transversal, e não, fragmentada e paralela, entre "missões da polícia ou missões dos militares".

A segurança do Estado é cada vez mais cooperativa e europeia, e cada vez menos, interna ou externa.

\section{REFERÊNCIAS}

Angelet, Bruno e Vrailas, Ioannis, 2008. European Defence in the wake of the Lisbon Treaty. Published by: Egmont Institute

Baldwin, David, 1989. Paradoxes of Power. Blackwell Pub; First Edition, pp. 45-81.

Baldwin, David, 1995. Security Studies and the end of the Cold War. World Politics 48, pp. 117-41.

Baldwin, David, 1997. The concept of security. Review of International Studies, British International Studies Association.

Baylis, J. \& Smith, 2007. The Globalization of World Politics. Oxford: Oxford University Press.

Booth, Ken, (1991). Security and Emancipation. In: Review of International Studies, vol. 17, n. ${ }^{\circ} 4$.

Bigo, Didier, 2000. When two became one: Internal and External Securitisations in Europe. In: Morten Kelstrup e Michael C. Williams (eds), International Relations Theory and the Politics of European Integration: Power, Security and Community. London: Routledge, pp. 171-204.

Booth, Ken, (2004). Critical Security Studies and world politics. London: Lynne Rienner Publishers.

Boutros-Ghali, Boutros. 1992. An agenda for peace: preventive diplomacy, peacemaking and peace-keeping. n. 17 jun. Nova Iorque. Disponível em: www.un.org.

Buzan, Barry, 1983. People, States \& Fear: the national security problem in international relations. University of North Carolina Press.

Buzan, Barry, 1991. People, States \& Fear: An Agenda for International Security Studies in the Post-Cold War. ECPR Press, reimpressão 2016.

Buzan, Barry; Hansen, Lene, 2010. The evolution of International security studies. Cambridge: Cambridge University Press.

Caetano, Manuel, 1963. Manual de Ciência Politica e Direito Constitucional. In: Col. Manuais da Faculdade de Direito de Lisboa, $4 .^{\text {a }}$ ed. Lisboa. 
Uma segurança interna cada vez mais europeia? Uma segurança externa cada vez mais nacional?

ANA MIGUEL DOS SANTOS

GALILEU - e-ISSN 2184-1845 - Volume XX - Issue Fascículo $2 \cdot 1^{\text {st }}$ July Julho $-31^{\text {th }}$ December Dezembro $2019 \cdot$ pp. 7-25

Canotilho, J. J. Gomes, 1984. Fidelidade à República ou Fidelidade à NATO. In: Estudos em Homenagem ao Professor Doutor Afonso Rodrigues Queiró. Coimbra: Boletim da Faculdade de

Direito da Universidade de Coimbra, pp. 131 a 207.

Canotilho, J. J. Gomes, 2003. Direito Constitucional e Teoria da Constituição. Coimbra: Almedina.

Canotilho, J. J. Gomes e Moreira, Vital, 2007. Constituição da República Portuguesa Anotada, Volume I. Coimbra: Coimbra Editora.

Carter, Ashton et al., 1992. A new concept of cooperative security. Washington: Brookings Institution.

Clapham, Andrew, 2009. Non-state Actors. In: Post-Conflict Peacebuilding: A Lexicon. New York: Oxford University Press.

Dahl, Robert Alan, e Lindblom, Charles Edward, 1953. Politics, Economics, and Welfare Political Science. Transaction Publishers.

Digeser, Peter, 1994. The Concept of Security. Paper delivered at the 1994 Annual Meeting of the American Political Science Association.

Gallie, W. B., 1956. Essentially Contested Concepts, Proceedings of the Aristotelian Society. Published by: Oxford University Press on behalf of The Aristotelian Society.

Gaspar, Carlos, 1990. O processo Constitucional e a Estabilidade do Regime. In: Análise Social, Vol. XXV, pp. 9-29.

Goodby, James, "Collective Security in Europe After the Cold War," Journal of International Affairs, Vol. 46, no. 2, pp. 299-321.

Hammes, T.X, 2006. War evolves into the fourth generation. In: Contemporary Security Policy, Vol. 26, No. 2, pp. 189-221.

Hempel, Carl G., 1972. Fundamentals of Concept Formation in Empirical Science. In: International Encyclopedia of Unified Science, $\operatorname{Vol} 2$, n. $^{\circ} 7$.

Hermenegildo, Reinaldo, 2018. A segurança interna da União Europeia: O caso da Guarda Costeira e de fronteiras. In: Proelium VII (14). pp. 147-182.

Herz, John H., 1950. Idealist Internationalism and the Security Dilemma. In: World Politics, Vol. 2, n. ${ }^{\circ} 2$ (Jan., 1950). Published by: Cambridge University Press. pp. 157-180.

Hobbes, Thomas, 1651. The Leviathan. Londres: Fontana/Collins, 1973.

Jackson, R., e Sorensen, G., 2003. Introduction to International Relations. Oxford: Oxford University Press.

Kaldor, M., 1999. New and Old Wars: Organized Violence in a Global Era. Cambridge: Polity Press.

Kerr, Pauline, 2006. Human Security. In: Collins, Alan (ed), Contemporary security studies. Oxford: Oxford University Press.

Mcsweeney, Bill, 1996. Identity and Security: Buzan and the Copenhagen School. In: Review of International Studies, vol. 22, n. ${ }^{\circ} 1$.

Mcsweeney, Bill, 1998. Durkheim and the Copenhagen School: a Response to Buzan and Wevver. In: Review of International Studies, vol. 24, n. $^{\circ} 1$.

Mearsheimer, John J., 1992. Disorder Restored. In: Graham Allison and Gregory F. Treverton (eds.), New York: Rethinking America's Security, pp. 213-37.

Miranda, Jorge e Medeiros, Rui, 2010. Constituição da República Portuguesa Anotada. 2. ${ }^{\text {a }}$ ed. Coimbra: Coimbra Editora.

Shani, Giorgio, 2016. Religion as security. In: Introduction, Critical Studies on Security, Vol. 4, n. ${ }^{\circ} 3$.

Shaw, M., 2005. The New Western Way of War: Risk Transfer war and its Crisis in Iraq. Cambridge: Polity Press.

Simon, Herbert A., 1976. Administrative Behavior: A study of Decision-making Processes in Administrative Organization, 3rd ed.. New York: The Free Press.

Smith, R., 2006. The Utility of Force: The Art of War in the Modern World. London: Penguin. 
Strange, S., 2002. The Declining Authority of States, in The Global Transformations Reader: an Introduction to the Globalization Debate. Held and macgrew (eds) Cambridge: Polity Press. $2^{\text {nd }}$ edition.

Ullman, Richard H., 1983. Redefining Security. In: Journal Article in International Security, Vol. 8, n. ${ }^{\circ}$.

Tarzi, Shah, 1997. The dilemma of collective security: a theorical critique. In: International Relations. London, Vol. 3, n. ${ }^{\circ} 6$.

Teixeira, Nuno Severiano, 2008. "O Tratado de Lisboa e o Futuro da Integração Europeia". In: Revista das Relações Internacionais, n. ${ }^{\circ} 18$, pp. 83-90.

Valente, Manuel Guedes, 2013. A segurança interna na Constituição da República Portuguesa de 1976. Disponível em http://www.iscpsi.pt/Inicio/Paginas/default.aspx/.

Walt and Colin Gray, 1982. Strategic Studies and Public Policy: The American Experience. Lexington: University Press of Kentucky.

Walt, Stephen M., 1991. The renaissance of security studies. In: Collins, Alan. Contemporary security studies. Oxford: Oxford University Press, 2007. P. 383-402.

Waltz, Kenneth N., 1979. Theory of International Politics. EUA: Waveland Press.

Waltz, Kenneth N., 1993. The Emerging Structure of International Politics. In: International Security, n. ${ }^{\circ} 18$.

Weber, Max, 1971. Le Savant et le Politique, Col 10/18. Paris : Union Générale des Éditons.

Williams, Paul D., 2008. Security Studies: An Introduction. In: Security Studies: An Introduction. Editor: Paul D. Williams. London and New York: Routledge. pp. 1-12.

Wolfers, Arnold, 1952. National Security as an Ambiguous Symbol. In: Political Science Quarterly, 67.

Wolfowitz, Paul, 200o. Remembering the Future. In: National Interest, 59, p. 35. 


\title{
Governo das sociedades e compliance em Portugal: um escorço de sua delimitação histórico-normativa
}

\author{
Corporate governance and compliance in Portugal: \\ a foreshortening of its historical-normative delimitation
}

\author{
PEDRO TROVÃO DO ROSÁRIO'
}

prsosario@autonoma.pt

PAULO ROBERTO BARBOSA RAMOS ${ }^{2}$

paubr@uol.com.br

DAVID ELIAS CARDOSO CAMARA ${ }^{3}$

david.camara1@outlook.com

GALILEU - REVISTA DE DIREITO E ECONOMIA - e-ISSN 2184-1845

Volume XX $\cdot 1^{\text {st }}$ July Julho $-31^{\text {TH }}$ December Dezembro $2019 \cdot$ pp. 26-45

DOI: http://doi.org/10.26619/2184-1845.XX.2.2

Submitted on September 30 th $2019 \cdot$ Accepted on November 15 th, 2019

Submetido em 30 de Setembro, 2019. Aceite a 15 d eNovembro, 2019

RESUMO O presente trabalho tem como objetivo analisar o sistema jurídico português de combate à corrupção, com um estudo especial sobre compliance, seus marcos normativos e desafios no cenário global empresarial que preza cada vez mais por ferramentas eficazes de governo. Para tanto, serão analisados os marcos internacionais de mitigação de riscos, tais como o relatório Greenbury (1995), o Sarbenas Oxley Act (2004), e a lei brasileira n.12.846 (2013). Vez levantado um escopo histórico-normativo acerca do desenvolvimento de tais

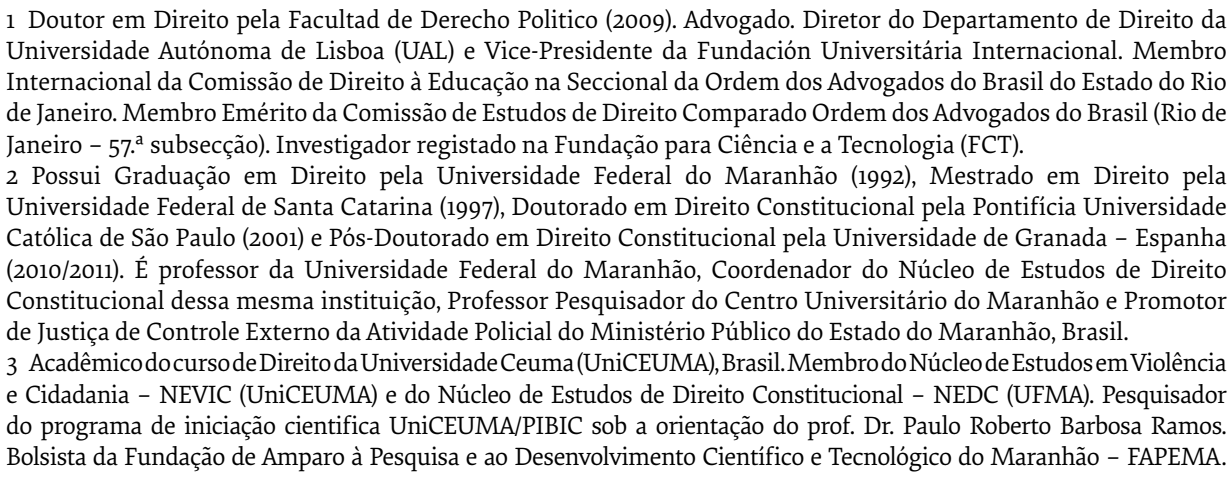


Governo das sociedades e compliance em Portugal: um escorço de sua delimitação histórico-normativa PEDRO TROVÃO DO ROSÁRIO | PAULO ROBERTO BARBOSA RAMOS | DAVID ELIAS CARDOSO CAMARA

GALILEU - e-ISSN 2184-1845 - Volume XX - Issue Fascículo 2 - 1st July Julho - 31 th December Dezembro 2019 - pp. 26-45

estruturas de combate à corrupção, será analisado se Portugal encontra-se em conformidade com o sistema internacional de governo das sociedades e de compliance.

PALAVRaS-ChaVE Governo das Sociedades. Compliance. Corrupção.

ABSTRACT This paper aims to analyze Portugal's structures of legality and corruption avoidance with a special look on compliance methods, its regulatory frameworks and challenges within a global corporate scenario that increasingly values government efficient tools. In order to achieve such purpose, it will be studied some international risk mitigation legal frameworks, such as the Greenbury report (1995), the Sarbenas Oxley Act (2004), and the Brazilian law n. 12.846 (2013). Once overcomed the historical-normative scope, it will be questioned whether Portugal is in fact aligned with the international system of compliance and corporate governance.

KEY WORDS Corporate Governance. Compliance. Corruption.

\section{INTRODUÇÃO}

Nas últimas três décadas, o debate a respeito da corrupção, da prevenção de riscos, da boa governança corporativa e do governo das sociedades intensificou-se a partir do surgimento de escândalos de corrupção envolvendo Estados de diferentes proporções e históricos, como o Reino Unido, os Estados Unidos e o Brasil - que tiveram que reestruturar os seus sistemas jurídicos de combate à corrupção, com a promulgação de normativos como, e.g., o relatório de Greenbury (1995), o Sarbenas Oxley Act (2004), e a lei n. 12.846 (2013).

De efeito, há um notável movimento global para o aperfeiçoamento e desenvolvimento de mecanismos para mitigação de riscos, tendo em vista que nenhum país está isento do fenômeno da corrupção.

No mundo, o debate a respeito do combate à corrupção adquiriu uma proporção inédita por parte dos agentes económicos, como empresas, investidores e a sociedade civil nas últimas décadas, tendo em vista que toda a coletividade, sem exceção, é prejudicada pelos efeitos mais nocivos das práticas desviantes como o enriquecimento ilícito, seja pelo branqueamento de capitais ou pela corrupção transnacional.

A par das atividades ilícitas no âmbito corporativo que corroem o tecido dos princípios da boa governança, da ética e da moralidade, iniciou-se um processo cooperativo entre os Estados para o enfrentamento de atos ímprobos, processo este que conta com a participação de atores supranacionais como Organizações Não Governamentais e Organismos Internacionais. 
A partir da década de 1990, em Portugal, foi possível assistir a uma mudança significativa em suas bases jurídicas para a mitigação e prevenção de riscos econômicos, principalmente pela constituição de órgãos de controles como a Comissão de Mercado de Valores Mobiliários (CMVM) - que possui legitimidade para fiscalização e controle de sociedades cotadas, e o Instituto Português de Corporate e Governance - que tem como objetivo a promoção e o desenvolvimento do governo das sociedades.

Tal cenário desenvolvimentista advém, principalmente, por parte do empresariado nacional e internacional que passaram a exigir regulamentos de maior proteção no setor empresarial, área mais vulnerada pela corrupção.

Todos estes marcos normativos de regulamentação possuem em comum medidas para a mitigação de riscos e combate à corrupção - objetivo central do governo das sociedades. Neste novo cenário de governo das sociedades, o empresariado e o Estado são os agentes de maior relevância e poder de atuação, tendo em vista que são possuidores de legitimidade para constituir práticas de boa governança nas áreas em que atuam.

Mais recentemente, uma nova ferramenta de proteção e prevenção veio à tona como aliado ao combate à corrupção: o compliance. Compreendido como um sistema empregado em uma empresa para alinhar um setor específico ou toda a organização dentro dos princípios éticos e morais da boa governança, o compliance surge a fim de mitigar as práticas criminosas amplamente debatidas no setor empresarial.

Apesar dos grandes esforços, contudo, é possível constatar que Portugal ainda se encontra em um processo de solidificação das referidas práticas de mitigação de riscos. Tal situação abre margem para discussões complexas sobre qual caminho o ordenamento jurídico português tende a seguir.

O presente artigo assim tem como objetivo geral, a partir de uma investigação histórica, examinar a evolução do governo das sociedades no combate à corrupção a nível global e analisar ainda tal desenvolvimento em Portugal, sob uma perspetiva essencialmente qualitativa - propondo um estudo entre os marcos legais de diferentes estados e seus respetivos mecanismos de proteção do capital e de governança corporativa.

\section{O governo das sociedades em Portugal: realidades e prospetos}

A globalização econômica levou a uma nova abertura do mercado de capitais aos investidores portugueses. A referida abertura econômica surge a partir da segunda metade do século XX, onde os nexos políticos, econômicos e sociais foram lesados no setor corporativo a partir das atividades criminosas advindas do fenômeno da derrubada de fronteiras 
comerciais, a exemplo da corrupção transnacional e do branqueamento de capitais, que, em síntese, têm como objetivo final o acrescimento patrimonial ilícito.

Assim, de modo a protegerem os seus interesses, os investidores internacionais passaram a exigir melhores e mais uniformizadas práticas de governança corporativa em Portugal, a partir da implementação das conhecidas políticas de segurança, integridade e transparência de capital, posto que o fenômeno da corrupção enquanto "problema social, estrutural, institucional e político, exige soluções igualmente estruturais" (BALLESTEROS, 2016, p. 23).

Portanto, o fator chave para o aprimoramento das práticas de boa governança não seria simplesmente superar a ausência de competência corporativa, mas sim, a superar a ausência de regulação voltada à redução de riscos em setores econômicos mais vulneráveis à corrupção.

Para tanto, é de suma importância que os estados em parceria com a sociedade civil e do empresariado, unam forças com o propósito de empregar e executar melhores normas de conformidade quanto a boa utilização de recursos públicos e privados.

Deste modo, a falta de políticas de combate à corrupção em tais setores econômicos permite que "se construa uma sensação de impunidade e, consequentemente, que se construa o fenômeno do abuso de poder econômico" (BALLESTEROS, 2016, p. 25).

Assim, a aplicação de medidas regulatórias de mitigação de vulnerabilidades promove, em tese, o processo de desenvolvimento econômico ao preservar os princípios da ética e moral no âmbito comercial, consequentemente, reduzindo eventuais insucessos no mercado devido a práticas de improbidade e possíveis processos devido aos atos de má-fé.

A este respeito, instaurou-se um novo momento de processo econômico e social voltados a mitigação de riscos advindos da corrupção, por meio do surgimento de normas, relatórios, comissões, instituições de controle, tratados internacionais e estudos voltados ao enfrentamento de atos nocivos a uma organização financeira.

O resultado prático da inserção das práticas de mitigação de risco é amplamente representado pelo chamado "governo das sociedades". Este sistema pelo qual as organizações financeiras são administradas e controladas mediante a supervisão de um ente regulador -revelam-se em uma "gama de ferramentas jurídicas e administrativas pelas quais os fornecedores e investidores de capitais são garantidos o retorno dos seus investimentos" (CUNHA, 2015, p.12).

Conhecido como Corporate Governance, ou simplesmente Governo das Sociedades ${ }^{4}$, esta teoria multidisciplinar abrange diversos campos de estudo, como a econômica, o direito

4 Em Portugal as agências de controle que possuem legitimidade para fiscalizar e executar as normas e diretrizes ao governo das sociedades atribuem diferentes nomenclaturas. De efeito, a Comissão do Mercado de Valores 
societário e o direito empresarial. De origem americana, a partir do emblemático estudo da “Teoria da Agência” de autoria dos economistas Adolph Berle e Gardnier Means, publicado em 1932, "o governo das sociedades tornou-se referência no estudo relacionado as medidas protecionistas no contexto corporativo". (PASSOS, 2017, p. 125).

Em meados da década de 1970, o governo das sociedades voltou a ser objeto de análise com a promulgação do Foreign Corrupt Practices Act (FCPA), pelo Congresso estadunidense, voltando a ser evidenciado em 2002, com o surgimento do Sarbenas Oxley Act (SOX) marco legislativo voltado ao combate à corrupção e branqueamento de capitais.

A partir de tais marcos iniciou-se um processo lento e gradual de cooperação internacional ao desenvolvimento e promoção do governo das sociedades. Para tanto, é de suma importância que os países constituam parcerias com o objetivo de constituírem regulamentos mais eficazes e sólidos de combate à corrupção.

Como explica Cunha (2012, p. 10): "À semelhança de outros crimes, a prevenção e repressão da corrupção impõe o reforço da cooperação internacional entre os Estados. Assim, se compreende que só uma perspetiva integrada do fenómeno da corrupção permitirá enfrentar esta ameaça e desenvolver adequadas ferramentas de prevenção e repressão".

Na União Europeia, por ilustrativo, o estudo do governo das sociedades iniciou-se em 1992 por meio do relatório Cadbury, "devido aos casos de fraudes e branqueamento de capitais envolvendo corporações do Reino Unido, como por exemplo a Marxwell, BCCI e a Mirror Group" (PASSOS, 2017, p. 128).

Em linhas gerais, o referido relatório modificou as estruturas de controle britânicas, reestruturando as ferramentas de mitigação de riscos, impondo, por exemplo, a necessidade de ser constituído uma área de auditoria interna no âmbito de toda pessoa jurídica empresarial.

Posteriormente, em 1995, surge o relatório Greenbury, com um caráter orientativo, que propõe às instituições financeiras situadas naquele mesmo país a constituição de uma relação entre os setores de administração e de transparência, promovendo, por exemplo, a divulgação das remunerações de seus funcionários, bem como dos sócios e investidores, por meio de relatórios anuais. Tal diretriz propõe também "a separação das funções de Presidente do Conselho de Administração e de Presidente da Comissão Executiva" (PIRES, 2008, p. 31).

Conforme explica Passos (2017, p. 128), "o relatório Greenbury redimensiona o cenário empresarial britânico quanto ao surgimento do princípio 'comply or explain', por esta 
as empresas devem declarar as normas que cumprem e justificar as situações de não-cumprimento".

Assim, inovações como essas levaram à ampliação do leque institucional britânico do combate à corrupção e a mitigação de riscos envolvendo instituições financeiras. Dessa forma, o Reino Unido redimensionou o cenário empresarial internacional no que tange a proteção do capital dos investidores.

Ao constituir assim uma efetiva cultura de boa governança corporativa com um víeis protecionista, este país foi elevado aos níveis de segurança quanto aplicação por parte de investidores e sócios, tornando-se referência no estudo de países que possuem um governo das sociedades realmente efetivo, posto que os riscos envolvendo atividades ímprobas no setor empresarial britânico são um dos menores, se comparados a nível global. ${ }^{5}$

A exemplo da experiência verificada no Reino Unido, outros países da União Europeia também desenvolveram marcos regulatórios com o intuito de salvaguardar o erário público e privado.

A Itália, por exemplificativo, promulgou em 1993 o Código de Comportamento dos Empregados das Administrações Públicas. O Código aludido prevê as regras de conduta, contratos e regulamentos com o objetivo identificar os comportamentos mais adequados à utilização do bem público. Já a França, em meados de 1993, instituiu sua respetiva lei sobre a prevenção da corrupção e a transparência da vida econômica.

Outro país europeu que reestruturou o seu sistema jurídico de mitigação de riscos foi a Espanha, em 1995, por meio da Lei n. 10, que criou o órgão denominado de Fiscalía Especial ou Fiscalía Anticorrupción, "membro integrante do Ministério Público espanhol com atribuição a repressão aos crimes econômicos relacionados à corrupção" (BLOCK, 2014, p. 14).

Assim, a nível intergovernamental, percebe-se através das palavras de Santos (2017, p. 29), que "há um movimento crescente de disseminação de iniciativas a favor do governo das sociedades".

Deste modo, a Organização para a Cooperação e Desenvolvimento Econômico (OCDE), a Organização dos Estados Americanos (OEA) e o Conselho da Europa (CE) podem ser destacados como exemplos de cooperação internacional ao combate as práticas criminosas no setor institucional financeiro posto que em suas atividades primárias, expedem orientações à boa governança empresarial.

Por ilustrativo, cumpre mencionar ainda a Convenção Interamericana contra Corrupção, como materialização deste crescente processo de ampliação do governo das socieda-

5 De acordo com o Transparency International (2018), o Reino Unido se posicionou na colocação de $11^{\circ}$ de 100 países menos corruptos. https://www.transparency.org/cpi2018; acesso em: 12/02/2019 
des. O referido marco, em seu texto, traz pontos importantes ao combate de atos de má-fé envolvendo o erário de uma instituição, estabelecendo a necessidade de regras de responsabilidade, de medidas que impeçam o suborno de funcionários nacionais ou estrangeiros.

Em 2003, de outro modo, a Organização das Nações Unidas (ONU) promulgou a Convenção Contra a Corrupção. O documento emitido por esta organização internacional, não obstante tenha força vinculante perante os membros signatários, na aceção de SANTOS (2017, p. 30), encontra sério problema e efetivação vez que "possui poucos mecanismos que garantam a aplicação de sanções por eventuais descumprimentos".

Diante dessa quadra, a ONU adotou uma série de diretrizes, como, por exemplo, a diretriz de n. 6, de políticas e práticas preventivas de corrupção, por seu turno, a de n.8 orienta para que os estados-membros constituam códigos de conduta para funcionários públicos.

Já em meados de 1999, a Organização para Cooperação e Desenvolvimento Econômico (OCDE) publica os Princípios de Governança Corporativa que, em seguida, foram atualizados em 2004 e revisados novamente em 2015. O documento é voltado para que os trinta e cinco Estados signatários da Convenção alinhem as suas instituições financeiras em conformidade com o governo das sociedades.

De acordo com Passos (2018, p. 132), os princípios mais relevantes são, em um primeiro momento, "assegurar a base normativa eficaz do governo das sociedades e a divulgação de informações, transparência e a responsabilidade civil, administrativa e penal dos agentes em conflito com as práticas de boa governança".

Neste sentido, a configuração moderna da relação entre Estado, pessoa jurídica empresarial e sociedade, já não se reduz aos ditames locais ou nacionais, nem tampouco às manifestações das instâncias formais do processo contra uma empresa.

Vive-se a era da democracia corporativa, em que o debate público amplo, realizado em contexto de livre circulação de ideias, de informações e medidas efetivas ao combate de toda e qualquer manifestação da corrupção, desempenha uma função racionalizada de desenvolvimento econômico.

\section{A comissão do mercado de valores mobiliários (CMVM) e o Instituto Português de Corporate Governance: breve histórico constitutivo e de sua atuação no modelo diretivo de governança corporativa}

Imerso no novo cenário do governo das sociedades e nas exigências do empresariado nacional e internacional, no que concerne a normatização e execução de mecanismos de mitigação de riscos, Portugal vem desenvolvendo instrumentos e práticas de boa governança, 
institucionalizando e reestruturando o seu ordenamento jurídico de combate à corrupção e mitigação de riscos econômicos.

Um exemplo prático da efetivação deste contexto no estado português, é a Comissão do Mercado de Valores Mobiliários (CMVM). Instituída em 10 de abril de 1991, pelo Decreto-Lei n. 142-A, a comissão é a instituição de controle com atribuições e competências para regular e supervisionar o mercado de valores mobiliários.

Sua função, em linhas gerais, é assegurar a proteção dos investidores, promovendo a eficiência, equidade, segurança e transparência do mercado de valores mobiliários. Nesse sentido, a CMVM que emite diretivas para instituições de mercado especificamente situadas em Portugal, é dotada de autonomia administrativa para a criação de comitês específicos de monitoramento nas mais diferentes áreas, como por exemplo, no setor de auditoria.

Esta comissão tem "competência na regulamentação e supervisão dos mercados de valores mobiliários e da atividade de todas as entidades, tanto públicas quanto privadas, que intervêm nesses mercados, sendo dotada ainda de autonomia financeira" (PASSOS, 2017, p. 132).

A especificidade do mercado imobiliário atrai a necessidade de maior regulamentação dada sua característica estratégica, do ponto de vista econômico, e dada sua vulnerabilidade.

Neste sentido, Jefferson Siqueira de Brito Álvares (2006, p. 154) muito bem esclarece no que consiste o mercado de valores mobiliários, e em que medida suas especificidades atraem melhor fiscalização:

[...] podem-se apontar os seguintes elementos cuja presença simultânea no mesmo instrumento financeiro o torna um valor mobiliário. Trata-se (a) da função econômica de instrumentar a captação de recursos para a consecução de empreendimento com fim lucrativo ou a obtenção de proteção contra riscos de variação de preços (hedge), (b) do risco potencial à poupança pública, (c) da negociabilidade e (d) da liberdade de forma. Com base nesses caracteres essenciais, é possível conceituar os valores mobiliários como instrumentos negociáveis de forma livre que instrumentam a captação de recursos para a consecução de empreendimentos com fim lucrativo ou a obtenção de proteção contra riscos de variação de preços (hedge), com risco potencial à poupança pública.

Em linhas gerais, referido mercado por ser compreendido como um mecanismo de distribuição de valores mobiliários que busca proporcionar uma maior proteção aos títulos emitidos por empresas e viabilizar seu processo de capitalização de recursos. 
No contexto português, as empresas pertencentes à bolsa de valores, corretoras e outras instituições financeiras participam do mercado mobiliário, contudo, estes "precisam estar em conformidade com as legislações locais e autorizadas pelo poder público" (Araújo, 2017).

As principais legislações que regulamentam o mercado de valores mobiliários português "estão presentes no Código dos Valores Mobiliários (CVM), aprovado em 13 de novembro de 1999, pelo Decreto-Lei n. 486 e ainda no Código das Sociedades Comerciais (CSC), aprovado em 02 de setembro de 1986 pelo Decreto-Lei n. 286" (CÂMARA, 2001, p. 14).

De acordo com Clotilde Passos, o Código dos Valores Mobiliários estabelece obrigações e sanções administrativas para as organizações econômicas abertas ${ }^{6}$, como, por exemplo, estabelecendo exigências quanto a prestação de informações do funcionamento da pessoa jurídica empresarial e de seus titulares, bem como quanto à transparência da identidade de seus investidores.

O Código das Sociedades Comerciais, noutro modo, é um instrumento normativo por meio do qual o governo português regulamenta o controle e a direção das instituições financeiras situadas no mercado português, embora não se restringindo às sociedades cotadas ${ }^{7}$.

Juntos, estes mecanismos de controle são possuidores de uma função social essencial para o funcionamento e caracterização de um mercado que preze pelo cumprimento de regulamentos a fim de mitigar riscos, evitando o comprometimento da integridade de empresas com condutas ilícitas, bem como, "fortalecendo a imagem de tais organizações perante a comunidade internacional, isto porque, as diretivas da Comissão do Mercado de Valores Mobiliários possuem um caráter essencialmente orientativo" (PASSOS, 2017, p. 135).

Essa espécie de soft law, que apenas pauta standards de governança corporativa, tem como objetivo oferecer uma maior liberdade de escolha ao empresariado em seu referido setor. Este grau de liberalidade permite aos agentes econômicos seguir os marcos orientativos da comissão, adaptando-os as especificidades e realidade econômicas de seu respetivo gênero de atuação.

A Comissão, que iniciou suas atividades ainda em 1991, emitiu as primeiras recomendações para as empresas cotadas e instituições financeiras emissoras de ações em mercado de valores, estabelecendo mecanismos de mitigação de risco de integridade que previam, por ilustrativo, a diretiva quanto a transparência em relação aos honorários pagos aos auditores e divulgação de informação obrigatória através de site na internet e, ainda, o "aperfeiçoa-

6 São consideradas sociedades de abertas as sociedades que têm capital disperso pelo público, nomeadamente as que tenham as suas ações admitidas à negociação num mercado de valores mobiliários regulamentado ou que tenham efetuado uma Oferta Pública de Venda (OPV) de mais de 10\% do capital

7 São consideradas sociedades cotadas aquelas em que o empresariado decide introduzir a sua empresa em bolsa de valores. 
mento da fiscalização interna na empresa, através, por exemplo, do sistema de auditoria interna" (PASSOS, 2017, p. 141).

Com efeito, diante das mutações econômicas do cenário internacional, e do novo cenário de gestão empresarial no início dos anos 2000, o Estado de Portugal realizou diversas alterações no Decreto-Lei n. 142-A, que instituiu a referida comissão.

Seguindo o estudo das revisões do Decreto-Lei n. 142-A, em novembro de 2003, houve uma nova revisão, por meio do regulamento n. 11, com o objetivo de normatizar os relatórios divulgados pelas empresas em Portugal. Em linhas gerais, a revisão teve como propósito atualizar o sistema de monitoramento, criando novos deveres de informações do mercado econômico.

Em meados de 2005 surgiram novas revisões para aperfeiçoar o sistema de fiscalização no setor empresarial português. Em 14 de abril de 2005, por meio do Regulamento n. 2, a CMVM passa a sugerir a criação de um gabinete de apoio ao investidor, o desenvolvimento de um sistema interno de controle para a deteção de riscos - com o objetivo de proteger e reduzir potenciais riscos devidos a condutas ilícitas, adoção de medidas para impedir o êxito de ofertas públicas de aquisição e o dever de respeitar os interesses das sociedades e seus acionistas.

O Decreto-Lei n. 142-A também veio sofrer novas edições a partir da constituição da Organização para o Desenvolvimento Econômico $(\mathrm{OCDE})^{8}$, da qual Portugal é membro integrante. Seguindo-se uma breve linha do tempo dos marcos regulatórios, já em 2007, as normativas já decretadas dão lugar ao primeiro Código de Governo das Sociedades em Portugal.

Em breve síntese, este documento visava alinhar Portugal aos novos ditames internacionais em relação ao governo das sociedades. Mediante o Regulamento de n.1, Portugal pela primeira vez emprega tacitamente o princípio comply or explain. Por este, as empresas devem "informar o grau de acolhimento das recomendações efetivadas pelo Código de Governo das Sociedades da CMVM e ainda o não amparo de tais diretrizes" (VICENTE, 2014, p. 14).

No ano de 2013 o estado português avança ainda mais no contexto do governo das sociedades. Por meio do Regulamento de n. 4 da CMVM, revoga-se o Regulamento de n.1 de 2010 e com o novo Código consagra-se a possibilidade de o empresariado português escolher um

8 Estas recomendações fazem parte do relatório da OCDE sobre princípios do Governo das Sociedades, que a OCDE publicou pela primeira vez em 1999 (Revista em 2004), depois de aprovado em conselho de ministros da OCDE. Este relatório assume grande relevância e passa a ser uma referência internacional para decisores políticos, investidores e outros intervenientes com interesses. Este assumiu tal importância, que o Fórum para a Estabilidade Financeira considerou que os Princípios da OCDE são uma das doze normas fundamentais para sistemas financeiros sólidos. 
código de governo das sociedades diferentes do da CMVM - condicionado, contudo, aos requisitos contidos em normas já estabelecidas.

Em termos gerais, o setor econômico de Portugal evoluiu com o surgimento do Regulamento de n. 4. Por meio deste, tanto os investidores nacionais como internacionais ficam mais livres em optar por um determinado sistema de controle o que consequentemente permitindo alinhar as empresas situadas no país ao âmbito internacional de competitividade.

Por fim, em 2018, o país reestruturou as bases do governo das sociedades, passando por uma transição para um modelo de autorregulação e recomendatório. A Comissão de Valores Mobiliários (CMVM), em parceria do Instituto Português de Corporate Governance (IPCG) lançam o Código de Governos das Sociedades do IPCG. Em linhas gerais, a nova legislação revoga o Código de 2013 da CMVM e se torna a única diretriz do Estado de Portugal para o empresariado situado no país.

Diante da análise evolutiva exposta, é possível constatar que o trabalho da Comissão do Mercado de Valores Mobiliários representa um considerável avanço na efetivação dos princípios éticos da governança corporativa.

Vez que Portugal demonstra adotar uma série de mecanismos institucionais a fim de estabelecer um ambiente de negócios antes de tudo justo e competitivo, torna-se claro perceber que as organizações institucionais não descuidam de padrões éticos e protecionistas diferenciados em termos de qualidade e conduta.

Mais do que um órgão de controle econômico, a Comissão de Mercado de Valores Mobiliários representa uma visão de maior competitividade para Portugal. Diante do novo cenário empresarial global que preza por um ambiente com menos corrupção e riscos para os sócios, investidores e consumidores, o país revela-se cada vez mais em sintonia com as necessidades de proteção da probidade e efetivação da justiça de mercado.

Certamente, revela-se fundamental na construção de um ambiente corporativo saudável e concorrente, a existência de uma instituição de controle que proporcione antes de tudo o diálogo entre os agentes econômicos.

Neste aspeto, ao perseguir formas de controles diversificadas das já instituídas com a Comissão de Mercado de Valores Mobiliários, Portugal ainda conta com as importantes contribuições do Instituto Português de Corporate Governance (IPCG) a luso ciência da governança corporativa.

Fundado em 2003, em breve síntese, o instituto tem por objetivo a investigação, divulgação e implementação dos princípios de Corporate Governance. Tal organização tem como base jurídica o direito privado e foi constituída mediante a associação sem fins lucrativos de desenvolvedores deste setor da ciência jurídica empresarial, dando ainda mais sustentáculo ao processo de estruturação e desenvolvimento do governo das sociedades. 
Diante da sua relevante missão institucional, é possível destacar a produção teórica sobre os conceitos e a prática do governo das sociedades. Por ilustrativo, em 6 de fevereiro de 2006, o IPCG lançou o Livro Branco sobre Corporate Governance em Portugal. O livro "aborda tópicos práticos do governo das sociedades, dedica algumas análises acerca dos códigos de um bom governo das sociedades, e as boas práticas de governança" (VICENTE, 2014, p. 21).

Já em 2013, o Instituto Português de Corporate Governance pública o seu Código de Governo das Sociedades. Diferente, este documento desenvolvido pela IPCG visa propor diretrizes para as sociedades abertas de Portugal, ao contrário das orientações de Governo das Sociedades efetivadas pela CMVM, que se restringia somente as sociedades cotadas.

Nos estudos de Vicente (2014, p. 22), "Tratou-se da resposta da sociedade civil à inexistência de um código de bom governo societário, não exclusivamente orientado para as sociedades cotadas, como é o caso do Código da CMVM".

Por fim, cumpre mencionar, que mais recentemente a Comissão de Valores Mobiliários (CMVM), em parceria com o Instituto Português de Corporate Governance (IPGC), constituíram um "Código do Governo das Sociedades". O novo Código visa amadurecer e desenvolver as estruturas jurídicas do Direito Societário de Portugal, por meio da regulação e supervisão da CMVM.

Em breve síntese, muito embora seja percetível a delineação de uma estrutura institucional da governança corporativa, de acordo com Clotilde Passos (2018, p. 68), "Portugal apresenta ainda uma evolução lenta no estudo e na promoção do Governo das Sociedades." Uma das razões elencadas por Passos para tal conclusão reflete na necessidade de "promover a efetiva prática de boa governança no setor empresarial do Estado".

\section{O compliance em Portugal: breve delimitação teórica}

A prática de corrupção existe desde a antiguidade como uma das formas mais problemáticas de violação aos direitos que os Estados enfrentam. Todavia, este cenário vem se transformando mediante as circunstâncias históricas, políticas, e socioeconômicas de modo que ao longo do tempo são notáveis as inúmeras mudanças da conduta pública e privada, especialmente quando se trata do uso de recursos financeiros.

No cenário internacional, desde a década de 1970, a corrupção tem obtido atenção especial, devido, principalmente, ao fenômeno da globalização econômica e, consequentemente, do surgimento da corrupção transnacional - definível como "processo de corrupção sistemática que vai além das fronteiras nacionais de um determinado ente soberano" (RAMINA, 2010, p. 21). 
Ante o estado de "corrupção globalizada", sobretudo entre agentes privados, desenvolveu-se um consenso no âmbito empresarial para a necessidade de elaboração de ações concretas de combate à corrupção.

Neste contexto, cumpre notar um dos mecanismos voltados ao combate da corrupção em nível transnacional, o compliance - instituído para prevenir, evitar, detetar e tratar qualquer desvio ou inconformidade devida à prática de corrupção.

Em breve síntese, referido mecanismo surge para contrapor a realidade de riscos e mitigar a eventual redução de potenciais investidores. Neste sentido, embora existam conceitos distintos acerca do significado da expressão "sistema de compliance", utiliza-se aqui a definição proposta por Block (2014, p. 85), para quem "significa agir de acordo com uma regra, uma instrução interna, um comando ou um pedido".

Dessa forma, estar em compliance significa que a pessoa jurídica pública ou privada está em conformidade com as exigências legais e regulamentares no âmbito corporativo que atua.

Além do compliance, o programa de integridade também inserido na lógica preventiva do combate à corrupção, é considerado importante mecanismo de combate à corrupção.

Aplicado primeiramente por meio do Foreign Corrupt Practices Act (FCPA), em decorrência do emblemático caso Watergate, o referido programa consiste no conjunto de procedimentos internos de integridade, auditoria e incentivo à denúncia de irregularidades e na aplicação efetiva de códigos de ética e de conduta, políticas e diretrizes com objetivo de detetar e sanar desvios, fraudes, irregularidades e atos ilícitos praticados no âmbito das pessoas jurídicas públicas ou privadas.

Outro notável mecanismo pioneiro de prevenção às práticas criminosas em âmbito financeiro, foi instituído através do UK Bribery Act, no Reino Unido. Com um "caráter punitivo contra qualquer ato de suborno perante administração pública" (GEWEHR, 2014, p. 24), a norma em questão, assim como o FCPA, estabeleceu uma quadra capaz de desenvolver a aplicação conjunta de diretrizes voltadas à rede global de mitigação de riscos econômicos.

Neste mesmo sentido segue a Lei n. 12.846/2013 - denominada de Lei Anticorrupção ou Lei de Empresa Limpa, que integra o quadro normativo internacional da prevenção e combate à corrupção, "reestruturou o sistema normativo brasileiro estabelecendo standards de prevenção e mitigação de riscos à pessoa jurídica envolvida em casos de corrupção" (BLOCK, 2014, p. 88).

Este novo regulamento foi capaz de alinhar o Brasil ao sistema internacional de países que buscam uma cultura corporativa e de cumprimento das leis e regulamentos, objetivando assim, a elaboração de padrões éticos em âmbito empresarial. 
A partir da análise de tais marcos normativos, é possível observar ser de extrema importância a regulamentação de exigências que cessem ou ainda mitiguem a prática de atos de corrupção, estabelecendo assim, estruturas normativas contra atos de improbidade que ao mesmo tempo permitam a prevenção de danos econômicos e estimulem a transparência e as boas práticas corporativas.

Isso porque a adoção destes mecanismos não somente viabiliza a criação de um sistema econômico saudável como ainda permite, um crescimento estratégico da economia.

Neste aspeto, a Organização das Nações Unidas (ONU), estima que " $5 \%$ do PIB mundial é branqueado" (ONU, 2013, p. 2), sendo capaz de desincentivar a aplicação de capital de investimento, especialmente em países notáveis por sua corrupção sistêmica.

Assim, o estado que não se alinhar a estas novas exigências, estará um passo atrás do mercado, tendo em vista que os investidores estão mais cuidadosos quanto aplicação de seu capital.

Diante deste contexto, no qual destacaram-se as inovações normativas levadas à cabo por Estados Unidos, Reino Unido e Brasil, destaca-se ainda o sistema legal português de prevenção e combate à corrupção.

Como ilustrativos, cumpre notar a Lei n. 34, de 15 de julho de 1987, que apesar de não estabelecer instrumentos de prevenção, tem como escopo "a responsabilização penal e civil de titular de cargo político e de alto cargo público que, em abuso de função ou grave desvio de interesses, e.g., prevaricar, solicitar ou aceitar vantagem patrimonial ou não patrimonial, que não lhe seja devida, ou ainda praticar qualquer ato ou omissão contrários aos deveres do cargo em virtude de vantagem indevida" (CUNHA, 2015, p. 17).

Demais, destaca-se ainda a Lei n. 5 de 11 de janeiro de 2002 que, em linhas gerais, cria um regime especial de recolha de prova, quebra de segredo profissional e perda de bens em favor do estado para diversos crimes advindos de corrupção.

Em 21 de abril de 2008, também, surge a Lei n. 20 que prevê a responsabilidade penal das pessoas coletivas e individuais por corrupção no setor privado e a corrupção com prejuízo do comércio internacional.

Posteriormente, é aprovada em 5 de junho a Lei de n. 25 de 2008, que estabelece medidas de natureza preventiva e repressiva de combate ao branqueamento de capitais advindas de ato ilícito e ao financiamento do terrorismo. Seguindo a linha do tempo dos marcos regulatórios ao combate à corrupção em Portugal, em 4 de setembro de 2008 a Lei de n. 54, que cria o Conselho de Prevenção da Corrupção.

Diante da legislação em apreço, é possível classificar o sistema normativo português de combate à corrupção em duas grandes áreas: uma, que tem o objetivo de criar normas que facilitem a relação dos cidadãos com a utilização da administração pública ou que também 
criam exigências éticas em âmbito corporativo, como, por ilustrativo, o comply or explain, e procedimentos administrativos transparentes; e outra, que instituída pelo código penal, tem o objetivo de dissuadir o crime.

Não obstante o histórico de leis anticorrupção datar desde a década de 1980, a "adoção do sistema de compliance em Portugal, tem pouco mais de uma década de efetivação" (PASSOS, 2014, p. 46). Com efeito, o país apresenta atrasos ${ }^{9}$ em relação aos demais estados-membros da União Europeia no que contempla medidas de prevenção e controle das práticas de corrupção no âmbito empresarial.

Apesar de tal constatação, o país ibérico possui arrojadas ferramentas de mitigação de riscos. Um exemplo capaz de ilustrar tal afirmação consiste na Comissão do Mercado de Valores Mobiliários (CMVM).

A comissão, instituída em 10 de abril de 1991 pelo Decreto-Lei n. 142-A, é a organização que possui legitimidade para regularizar os códigos de integridade empresarial e, assim como, supervisionar funcionamento dos mercados de valores mobiliários e a atividade das instituições públicas e privadas que possuem atuação no território lusófono.

São ainda atribuições da Comissão de Valores Mobiliários ${ }^{10}$ :

Sancionar as infrações ao Código dos Valores Mobiliários e legislação complementar; Assegurar a estabilidade dos mercados financeiros, contribuindo para a identificação e prevenção do risco sistémico; Contribuir para o desenvolvimento dos mercados de instrumentos financeiros; Prestar informação e tratar as reclamações dos investidores não qualificados; Proceder à mediação de conflitos entre entidades sujeitas à sua supervisão e entre estas e os investidores; Coadjuvar o Governo e o respetivo membro responsável pela área das Finanças(...).

Ou seja, como se verifica, Portugal atribuiu a CMVM sendo a organização reguladora de instituições empresariais públicas e privadas situadas no país. Contudo, ainda que inserida em uma estrutura organizacional hierarquizada na qual é submetida às esferas de decisão superior, esta organização possui autonomia administrativa para criar normas e exercer seu papel fiscalizador no âmbito do mercado de valores.

9 A este propósito, vale a pena destacar um estudo realizado pela Heidrick e Struggles acerca do Corporate Governance na Europa, onde se constata o referido atraso na dimensão que se reporta à análise dos órgãos de administração das empresas, o rating encontrado para Portugal foi o mais baixo.

10 As atribuições da Comissão de Valores Mobiliários encontra-se no sítio eletrônico da própria instituição de controle portuguesa: https://www.cmvm.pt/pt/CMVM/Apresentacao/Pages/Apresentacao-o-que-e-a-CMVM. aspx. 
Neste aspeto, o empresariado português vê uma problemática, tendo em vista que a Comissão de Mercado de Valores Mobiliários se apresenta como a única organização de controle no setor de fiscalização das sociedades cotadas no país.

Fazendo com que restrinja o investimento econômico por parte de potencias investidores, já que as instituições financeiras não cotadas nas bolsas de valores portuguesas não são contempladas pelo Código da CMVM.

Diante deste quadro, em 1 de fevereiro de 2010, a CMVM publicou o Regulamento n.1, que "veio reconhecer as empresas o direito de optarem por um código de governo diferente daquele que foi emitido pela Comissão" (SANTOS, 2017, p. 77).

Assim, nas palavras de Miguel Vicente (2014, p. 32), "trata-se da resposta da sociedade civil à inexistência de um código de bom governo societário, não exclusivamente orientado para as sociedades cotadas".

Nesse sentindo, redimensionando o quadro normativo de Portugal na relação de imposição quanto a implantação do código de ética nas pessoas jurídicas e, alocando a dita questão para o empresariado português quanto a opção de implantar ou não mecanismos de integridade na pessoa jurídica.

Com efeito, a partir dessa transição impositiva, para uma questão optativo do governo de Portugal, este novo cenário empresarial vai no sentido de maior regulamentação e liberdade dada ao mercado econômico em unir forças como o Estado para o combate às fraudes.

Portanto, a política adotada por Portugal se assemelha com as novas mudanças que vem se operando a nível da União Europeia, Estados Unidos e Brasil, que a tendência é para recorrer às recomendações, em vez de obrigações - o objetivo essencial do compliance.

\section{CONCLUSÃO}

Os atos atentatórios que vão de encontro aos princípios do Governo das Sociedades, envolvendo de sobremodo o branqueamento de valores e a corrupção transnacional - levados à cabo pelo intenso processo de abertura do mercado de capitais no novo cenário de globalização econômica, são fenômenos cada vez mais objeto de atenção por parte dos estados nacionais e da sociedade civil organizada.

Seja porque o fenômeno da corrupção enquanto problema social e estrutural, exige-se soluções igualmente estruturais, seja porque ainda é capaz de fulminar o pleno desenvolvimento dos agentes econômicos, certo é que novas estratégias de regulação voltada à redução de riscos em setores econômicos mais vulneráveis à corrupção é uma realidade atual encorajada por todos aqueles comprometidos com o desenvolvimento de um mercado justo. 
Tais estratégias podem ser precisamente delineadas no âmbito normativo, a partir da análise dogmática da legislação econômica dos países, e ainda na difusão de mecanismos de controle, monitoramento e de combate à corrupção.

Em termos de revisão normativa, são destacáveis os marcos legais de corporate governance apresentados nos Estados Unidos, Reino Unido e Brasil, como, e.g., o relatório de Greenbury (1995), o Sarbenas Oxley Act (2004), e a lei n.12.846 (2013) que constituíram uma efetiva cultura jurídica de boa governança corporativa com um víeis essencialmente protecionista.

Já os mecanismos institucionais de controle e monitoramento podem ser ilustrados objetivamente em setores governamentais e não governamentais como, e.g.,a Organização para a Cooperação e Desenvolvimento Econômico (OCDE), a Organização dos Estados Americanos (OEA) e o Conselho da Europa (CE). Tais organismos, que expedem orientações à boa governança empresarial, podem ser destacados como exemplos de cooperação internacional no combate as práticas criminosas no setor financeiro.

Em que pese possam apresentar estágios particulares de aplicação das técnicas de governança corporativa, todos estes países possuem algo em comum: todos tiveram em algum momento que se deparar com a problemática da corrupção em suas instituições econômicas, seja no setor privado ou público.

O Governo das Sociedades surge assim para estabelecer ambiente mais seguro para os investidores e a sociedade civil, tendo em vista que a sua atuação envolve principalmente setores vulnerados pela corrupção, por exemplo, a economia, o direito societário e o direito público.

O seu caráter orientativo surge com o objetivo de proteger os interesses dos stakeholders, por meio da gestão e ferramentas de controles mais rigorosas e eficientes contra os atos criminosos que possam ocasionar qualquer dano ao erário da pessoa jurídica pública ou privada. Visa ainda, a transparência das ações financeiras e, assim, como a responsabilização dos órgãos da Administração.

Mais recentemente surge o Compliance. No contexto corporativo, a adoção de tal mecanismo significa um maior grau de proteção para os investidores, tendo em vista que o emprego deste mecanismo de prevenção busca, também, melhorar a atuação da empresa em seu respetivo setor, evitando, assim, processos civis e administrativos que podem colocar em risco os negócios e aplicações.

O emprego deste mecanismo, por oportuno, não somente viabiliza a criação de um sistema econômico saudável, pautado nos princípios éticos e morais da boa governança, como ainda permite um crescimento estratégico da economia, ao passo que o empresariado 
internacional busca investir o seu capital em países com melhores graus de segurança e combate à corrupção.

Em Portugal, o sistema de Compliance é constituído, ainda que indiretamente, por meio da Comissão de Mercado dos Valores Mobiliários (CMVM) e do Instituto Português de Corporate Governance (IPCG).

Com efeito, por mais que tais organizações de controles sejam competentes na fiscalização e regulamentação do empresariado português bem como na elaboração de orientações e diretrizes à mitigação de riscos e práticas de boa governança, Portugal ainda não reconhece o programa de compliance expressamente, posto que não detém de um marco normativo que defina tal conceito e unifique sua aplicação sobre os agentes econômicos sob sua jurisdição.

Gradualmente, porém, o país lusitano vem se estruturando organizacionalmente para o novo cenário internacional de práticas de mitigação de riscos, mas a evolução ainda é pequena se comparada à nível global.

A aplicação de um programa de prevenção e mitigação da corrupção, como o compliance, nas empresas deixou de ser uma questão optativa, mas sim, uma perspetiva de necessidade e universal para os Estados que quiserem prosperar no mercado econômico.

\section{REFERÊNCIAS}

ÁLVARES, Jefferson Siqueira de Brito. O Atual Conceito de Valor Mobiliário. In: Revista de Direito Mercantil, Industrial, Econômico e Financeiro, n. 142, abr./jun. 2006

ARAÚJO, Alan Pereira de. A CVM e a Taxa de Fiscalização dos Mercados de títulos e Valores Mobiliários. In: Revista da AGU, vol. 17. n. 2. abr./jun. 2018

BALLESTEROS, Irma Eréndira Sansoval. Enfoque de la corrupción estructural: poder, impunidad y voz ciudadana. In: Revista Mexicana de Sociología; vol. 78. n. 1, ene. /marzo 2016

BLOCK, Marcella. Nova Lei Anticorrupção (Lei 12.846/2013) e o Compliance. In: Revista de Direito Bancário e Mercado de Capitais. Vol. 65. 2014.

BRASIL. Lei n. 12.846, de 1. de agosto de 2013. Disponível em: < http://www.planalto.gov.br/ccivil_03/_ ato2011-2014/2013/lei/l12846.htm.>. Acesso em 02 Fev. 2019.

CÂMARA, Paulo. O Governo das Sociedades em Portugal: Caderno do Mercado de Valores Mobiliários. 12. 2001

CUNHA, Ary Ferreira. Combate à corrupção: da teoria à prática. Lisboa: Quid

ESPAÑA. Ministerio de la Presidencia, relaciones Con Las Cortes e Igualdad. Fiscalia Organizad. Disponível em: < https://www.boe.es/buscar/doc.php?id=BOE-A-1995-10066

FRANCE. Legisfrance. la prévention de la corruption et à la transparence de la vie économique et des procédures publiques de 1994. Disponível em: https://www.legifrance.gouv.fr/affichTexte. do;jsessionid=0535B92AF63FoF2BA4E4A24D6FB32B8A.tplgfr25s_1?cidTexte=JORFTEXToooooo 7 $11604 \&$ dateTexte $=20090716>$. Acesso em 16 Fev. 2019. 
GEWEHR, Elson Dérin. Compliance na Gestão de Fundos de Investimento. Dissertação (Dissertação em economia). UFRGS Rio Grande do Sul. 2011.

GOVERNANCE, Instituto Português de Corporate. Livro Branco Sobre Corporate Governamental em Portugal, 2006. Disponível em: < http://www.ecgi.org/codes/documents/libro_bianco_cgov_pt.pdf>. Acesso em 26 Jan. 2019

GOVERNANCE, Instituto Português de Corporate. Cadernos do IPCG (2001) Sobre Corporate Governance Boas Práticas dos Órgãos de Administração das Sociedades 1. ${ }^{\circ}$ fascículo 26 de Abril de 2011. Acesso em 27 Jan 2019.

GOVERNANCE, Instituto Português de Corporta. Código de Governo das Sociedades, 2018. Disponível em: https://cgov.pt/images/ficheiros/2018/codigo-pt-2018-ebook.pdf Acesso em: 05 fev. 2019

HEIDRICK \& STRUGGLE. Is Your Board Fit For the Global Challenge? Corporate Governance in Europe. Disponível em: <http://www.heidrick.com/NR/rdonlyres/DACDA5Co-7DD5-4A8DAE86-A50Ao1CFCD57/o/HS_CorpGovEurope.pdf >. Acesso em 14. Fev. 2019.

INTERNACIONAL, Transparency. Corruption Perceptions Index. Disponível em $<$ https://www.transparency. org/cpi2018>. Acesso em: 24. Jan, 2019

ITALIA. Presidenza del Consiglio del Ministri Dipartimento Della Funzione Pubblica. Codice di comportamento dei dipendenti delle pubbliche amministrazioni de 1993- Disponível em: <http://www. beniculturali.it/mibac/multimedia/MiBAC/documents/1375440149998_Codice_di_comportamento_ dei_dipendenti_delle_pubbliche_amministrazioni.pdf $>$. Acesso em: 16 Fev. 2019.

, Recomendações da CMVM sobre o Governo das Sociedades Cotadas, Nov. 2003. Disponível em <http://www.cmvm.pt/recomendacoes_e_orientacoes/recomendacoes/soccot_nov2003/indice.asp>. Acesso em 22 Jan. 2019.

MOBILIÁRIOS, Comissão do Mercado de Valores. Recomendações da CMVM sobre o Governo das Sociedades Cotadas. Disponível em: < http://www.cmvm.pt/pt/Legislacao/Legislacaonacional/ C\%C3\%B3dGoverno\%2odas\%20Sociedades/AnexosGovSoc/Pages/99_indice.aspx>. Acesso em 22 Jan. 2019.

MOBILIÁRIOS, Comissão do Mercado de Valores. O que é a CMVM? Disponível em: <https://www.cmvm. pt/pt/CMVM/Apresentacao/Pages/Apresentacao-o-que-e-a-CMVM.aspx>. Acessp em 24 de Jan. 2019.

OCDE, principles of Corporate Governance. 1991. Disponivel em: http://www.oecd.org/daf/governance/ principles.htm. Acesso em 30 Jan. 2019.

ONU. Convenção Contra Corrupção. 2003. Disponível em:<https://www.unodc.org/unodc/en/treaties/ CAC/>. Acesso em: 16 Jan. 2019

ONU. Corrupção e desenvolvimento. 2013. Disponível em: < http://www.unodc.org/documents/lpo-brazil/ Topics_corruption/Campanha-2013/CORRUPCAO_E_DESENVOLVIMENTO.pdf>. Acesso em: 16 jan, 2019.

PASSOS, Clotilde. Governo das Sociedades - Diagnóstico da Situação em Portugal. In: Revista Gestão e Desenvolvimento, n. 25. 2017.

PIRES, Ana Isabel Marinho. Impacto da Lei Sarbanes - Oxley no Sistema de Controle Interno das empresas cotadas nos EUA - O caso Português; Mestrado em Contabilidade e Auditoria; Universidade Aberta. 2008.

RAMINA, Larissa. A Convenção Interamericana Contra a Corrupção: uma breve análise. In. Revista Direitos Fundamentais \& Democracia. Vol. 6. 2008.

SANTOS, Diogo De Almeida Viana Dos. Compliance e Legislação Anti-Corrupção: Uma perspectiva Comparada. In: Revista Brasileira de Filosofia do Direito, Vol. 4. n. ${ }^{\circ}$ 1. 2018. 
UK Foreign Bribery Strategy. Londres, 2015. Disponível em: <http://webarchive.nationalarchives.gov. uk/20121205231543/http://www.officialdocuments.gov.uk/document/cm77/7791/7791.pdf >. Acesso em: 14 Jan. 2019.

UNITED STATES. Foreign Corrupt Practice Ack. Washington, abr. 1977 Disponível em:<

https://www.justice.gov/sites/default/files/criminal-fraud/legacy/2012/08/29/corruptrpt-95213.pdf >. Acesso em: 30 Jan. 2019.

VICENTE, Pedro Miguel dos Santos Ferreira Vicente. Corporate Governance e Setor Empresarial Público em Portugal: Contributo para um normativo regulador. Mestrado em Gestão e Políticas Públicas. ISCSP. Lisboa. 2014 


\title{
Papel da Vitima no Direito Português e no Direito Internacional
}

\author{
The Role of the Victim in Portuguese Criminal Law and \\ in International Law
}

MARIA JOÃO SIMÕES ESCUDEIRO

mjsescudeiro@gmail.com

GALILEU - REVISTA DE DIREITO E ECONOMIA - e-ISSN 2184-1845

Volume XX $\cdot 1^{\text {st }}$ July Julho $-31^{\text {TH }}$ December Dezembro $2019 \cdot$ pp. 46-60

DOI: http://doi.org/10.26619/2184-1845.XX.2.3

Submitted on September $25^{\text {th }}, 2019 \cdot$ Accepted on November $15^{\text {th }}, 2019$

Submetido em 25 de Setembro, 2019 . Aceite a 15 de Novembro, 2019

RESUmo A criação do Tribunal Penal Internacional é um dos feitos mais aguardados do século vinte.

As expetativas e anseios que recaem sobre o Tribunal são, de tal forma altos, que colocam a Comunidade Internacional de olhos postos nas suas decisões.

O Estatuto da Vítima está em vigor em Portugal e perante esta circunstância importa analisar o papel das vítimas nos Tribunais Penais Internacionais.

Analisaremos a evolução do papel das vítimas nos Tribunais Militares Internacionais de Nuremberga e do Extremo Oriente, passando pelos Tribunais Ad-Hoc da Ex-Jugoslávia e do Ruanda e culminando no Tribunal Penal Internacional.

A evolução nesta matéria é visível na prática destes tribunais, até porque a análise que se pretendemos fazer, é sobretudo, com base na jurisprudência destes Tribunais.

PALAVRASCHAVES Vítima(direitos, papel,preponderância), Tribunais Penais Internacionais; Jurisprudência.

ABSTRACT The creation of the International Criminal Court is one of the most waited achievements of the twentieth century.

The expectations and desires that befall upon the Court are so high, that the eyes of the International Community are put in its decisions.

The Problems of Victims came into force in Portugal with this Law and we must examine the role of victims in International Criminal Tribunals. At this point, it's important that we analyze the evolution of the role of victims in International Military Tribunals of Nuremberg and Tokyo, through the Ad-Hoc Tribunals of the former Yugoslavia and Rwanda and culminating in the International Criminal Court. 
Papel da Vítima no Direito Português e no Direito Internacional

MARIA JOÃO SIMÕES ESCUDEIRO

GALILEU - e-ISSN 2184-1845 - Volume XX - Issue Fascículo 2 - $1^{\text {st }}$ July Julho $-3^{\text {th }}$ December Dezembro 2019 - pp. 46-60

Developments in this field is visible in the practice of these courts, because the analysis that we intend to do, mainly based on the jurisprudence of these Courts.

KEY WORDS Victim (rights, role, prevalence), International Criminal Tribunals; Jurisprudence.

\section{Introdução}

Este artigo pretende analisar a problemática do papel da vítima no âmbito internacional, mas também, no âmbito do direito interno, por força de vigorar em Portugal o Estatuto da Vítima, que resultou da transposição de uma diretiva europeia'.

Consideramos que a evolução do Direito Internacional Penal e do Direito Processual Penal Internacional terá necessariamente reflexos no sistema jurídico português.

O tema que elegemos como objecto deste artigo reveste um especial interesse, em virtude de não se encontrar entre a doutrina portuguesa trabalhos de investigação que apresentem uma visão global detalhada sobre o papel da vítima nos procedimentos criminais internacionais, designadamente à luz do labor dos diversos tribunais penais internacionais e ao mesmo tempo concluindo da sua aproximação às famílias jurídicas da Civil e da Common Law. Assim, é também o nosso objectivo contribuir modestamente para preencher este vazio. Os Tribunais Penais Internacionais são instituições que, pela sua credibilidade e importância, tenderão, cada vez mais, a ser uma referência para as jurisdições nacionais. Os princípios orientadores da justiça internacional terão um reflexo, cada vez mais imediato, no desenvolvimento do direito interno dos Estados. Daí que acreditemos que este estudo contribua para uma nova abordagem a esta questão, o que nos permitirá observar o direito processual penal de outra forma com a vantagem da experiência internacional. Este conhecimento evita possíveis erros legislativos e antecipa problemas doutrinais e jurisprudenciais. Cremos que o desenvolvimento do direito processual penal português sairá beneficiado se o legislador e o julgador conhecerem os problemas e as soluções que, diariamente, vão surgindo nos Tribunais Penais Internacionais.

\footnotetext{
1 Transposição da Diretiva 2012/29/UE do Parlamento Europeu e do Conselho, de 25 de outubro de 2012, que estabelece normas relativas aos direitos, ao apoio e à proteção das vítimas da criminalidade e que substitui a Decisão-Quadro 2001/220/JAI do Conselho, de 15 de março de 2001.
} 


\section{Direito Português: Breves notas}

Desde o dia 4 de Setembro de 2015, entrou em vigor a Lei n. ${ }^{\circ}$ 130/2015, intitulada o Estatuto da Vítima. Esta lei resulta da transposição da Directiva 2012/29/EU do Parlamento Europeu e do Conselho, de 25 de Outubro de 2012. Este diploma estabelece normas relativas aos direitos, ao apoio e à proteção das vítimas de crimes.

O Direito Criminal Português, assim como, o Direito Penal Internacional tem o enfoque no agressor e nos direitos dos criminosos, daí que se verifique a necessidade de recentrar a vítima no processo criminal, tendo em consideração e esta se encontra muitas vezes arredada de todo o procedimento.

Com a entrada em vigor deste diploma e com a autonomização o conceito de vítima, inexistente até à data, procede-se à regulação dos seus direitos e consequentes apoios, partindo sempre da premissa que estamos perante um sujeito que se encontra por inerência fragilizado. Por outro lado, incluem-se na categoria de vítimas especialmente vulneráveis as vítimas de criminalidade violenta e criminalidade especialmente violenta, as crianças, os idosos ou aqueles que tenham especiais problemas de saúde que requeiram este estatuto.

Com a introdução deste diploma no ordenamento jurídico português, procedeu-se à enunciação expressa que a vítima que não se constituiu assistente, nem demandante civil, tem agora o direito de oferecer provas e ser ouvido. Mas mais, acrescentou-se o alargamento da possibilidade da vítima se constituir assistente após a leitura da sentença para interposição de recurso.

Esta Lei introduz ainda alterações aos Código de Processo Penal, onde se estabeleceu que vítima é não só a pessoa diretamente atingida pela prática de um crime, mas também aqueles que a rodeiam e que sofreram consequências com isso, designadamente o cônjuge, a pessoa com quem ela vive em união de facto, parentes em linha reta, irmãos ou pessoas a cargo.

Os princípios pressentes neste estatuto (doravante $\mathrm{EV}$ ), são a igualdade (art. $3 .^{\circ} \mathrm{do} \mathrm{EV}$ ), respeito e reconhecimento (art. $4 .^{\circ} \mathrm{do} \mathrm{EV}$ ), autonomia da vontade (art. $5 .{ }^{\circ} \mathrm{do} \mathrm{EV}$ ), confidencialidade (art. 6. ${ }^{\circ}$ do EV), consentimento (art. 7. ${ }^{\circ}$ do EV) e informação (art. 8. ${ }^{\circ}$ do EV). Desta forma, garantiu-se o sigilo de todas as informações prestadas pela vítima e prevê-se ainda o acesso da vítima aos cuidados de saúde, em função do tipo de crime. Além disso, há lugar ao reembolso das despesas efetuadas, existe o direito de proteção da vítima, devendo ser evitado o contacto direto com o arguido.

Previu-se igualmente a obrigação de prestar apoio psicossocial às vítimas vulneráveis e especialmente vulneráveis (arts. 20. ${ }^{\circ}$ e ss. do EV), bem como, a possibilidade de prestarem declarações para memória futura, conforme o art. $24 .^{\circ}$ do $\mathrm{EV}$. 
No que respeita ao direito à informação, estabeleceu-se que a vítima deve ser informada sobre onde e como pode apresentar a denúncia, sobre os requisitos que regem o seu direito à indemnização, bem como o direito de ser informada quanto à sentença. Mais, terá também direito à informação sobre o estatuto do arguido, nomeadamente a sua libertação, revogação da decisão, ou mesmo, casos de alteração das medidas de coacção, de acordo com o art. $11 .^{\circ}$ previsto no EV.

Finalmente, determinou-se de uma forma muito inovadora que a vítima seja ouvida mesmo nos casos em que haja alteração da medida de coação. Para este efeito, a vítima deve ser sempre ouvida de forma "reservada", i. e., num gabinete dos órgãos de polícia criminal.

\section{Direito Internacional: Notas Introdutórias}

Os Juízes do Tribunal Penal Internacional (TPI) têm competência para resolver todas as questões processuais penais, mas também as questões relativas à reparação das vítimas - art. 75. ${ }^{\circ}$ do Estatuto de Roma. (Bassiouni, M. Cherif; 2005 Vol. 2; pp. 544-549.; Triffterer, Otto; 2008, pp. 1399-1412; Cassese, A. and Others; 2002, 2002; pp. 1399-1416) O TPI define que serão estabelecidos os princípios aplicáveis às formas de reparação das vítimas, nomeadamente, a restituição, a indemnização e a reabilitação. O termo «princípios» atribui aos Juízes discricionariedade que permite a flexibilidade necessária para determinar as consequências dos crimes cometidos sob a jurisdição do TPI. (Triffterer, Otto; 2008; pp. 1402-1405).

O Estatuto de Roma é conhecido pelas suas previsões inovadoras, designadamente, no que diz respeito ao tratamento das vítimas. Esta novidade atribui às vítimas o direito de participarem no processo. (Lee, Roy; 2001; pp. 235-255) Brianne N. Macgonigle afirma que o papel e os direitos das vítimas diferem consoante se enquadrem no sistema adversarial ou inquisitorial. Embora mesmo entre os sistemas inquisitoriais se encontrem diferenças, todos concedem uma posição participativa às vítimas, designadamente através da participação das partes civis. Nos sistemas inquisitoriais, as vítimas têm um papel processual em que são a fonte da informação para o Tribunal, enquanto testemunhas, mas também como alguém que sofreu os danos, ou seja, enquanto vítima. O papel mais importante das vítimas neste sistema é o direito de pedir uma indemnização pelos danos sofridos, diretamente no decorrer do procedimento criminal. (Lee, Roy; 2001; pp. 235-255) Às vítimas é permitido apresentar os seus argumentos e preocupações, assim como questionar as testemunhas e recorrer contra a absolvição do arguido. ${ }^{2}$

2 Idem. Segundo este autor "este procedimento é vantajoso para as vítimas se o arguido for condenado, porque não terão de provar a culpa do arguido pelos danos sofridos num processo civil autónomo. Por outro lado, quando um arguido é absolvido, as jurisdições não são uniformes quanto à questão de saber se as vítimas podem ou 
Diferentemente, os sistemas adversariais não admitem a participação das vítimas nos procedimentos a não ser como testemunhas, visto que não são partes formais no processo. (Macgonigle, Brianne N.; Artigo 2009; p. 5); (Jouet, Mugambi;Artigo 2007; p. 4) Nos sistemas adversarial, as vítimas podem participar como testemunhas, ficando sujeitas às questões da defesa. Os sistemas da Common Law confiam nos resultados que se obtém da argumentação e contra-argumentação entre as partes. Estes sistemas equilibraram o papel limitado atribuído às vítimas defendendo os seus interesses de outras formas. Por exemplo, no sistema inglês os Juízes têm autoridade para ordenar que o arguido pague indemnizações às vítimas, mesmo que estas não o tenham solicitado. (Jouet, Mugambi; Artigo 2007; p. 4) Para além da indemnização através do procedimento criminal, os sistemas da Common Law permitem que as vítimas obtenham compensação para os danos sofridos nos tribunais cíveis. Por exemplo, nos EUA as vítimas podem recorrer aos tribunais cíveis para obterem as suas indemnizações, até porque estes tribunais são menos exigentes com a prova dos que os tribunais criminais. (Jouet, Mugambi; Artigo 2007; p. 4)

A evolução apresentada pelo TPI apresenta-nos uma característica dos sistemas da Civil Law permitindo uma reparação dos danos sofridos pela vítima, ao contrário do que sucedia nos Tribunais Militares ou nos Tribunais Ad Hoc em que se seguiu um procedimento principalmente adversarial, sendo a participação das vítimas "resumida" ao seu papel enquanto testemunhas. O objetivo desta novidade é o facto de se acreditar que as vítimas têm um interesse próprio nos procedimentos internacionais que não pode ser salvaguardado através da representação de outra parte. (McGoldrick, Dominic and Others; 2004; p. 320). Os procedimentos internacionais podem claramente beneficiar com a participação das vítimas que têm conhecimentos na primeira pessoa os atos alegadamente praticados pelo arguido. ( Jouet, Mugambi; Artigo 2007; p. 4)

$\mathrm{O}$ art. $75 .^{\circ}$ do Estatuto de Roma vem suprimir uma séria lacuna dos Estatutos do TPIJ, do TPIR e dos Tribunais Militares de Nuremberga e de Tóquio, que não definiam a questão da reparação das vítimas. (Triffterer, Otto; 2008; p. 1411)

Nos Tribunais Ad Hoc, os interesses das vítimas foram muitas vezes negligenciados, porque estes Tribunais só tiveram em conta o seu papel enquanto testemunhas. Durante os procedimentos, as vítimas só eram ouvidas como testemunhas da acusação ou da defesa. Neste sentido, as vítimas não poderiam ser compensadas pelo sofrimento vivenciado. Esta situação era deixada para os tribunais nacionais ou para outra instituição competente.

não iniciar um processo civil, com o obejtivo de obterem uma indemnização. Por exemplo, a lei francesa proíbe que os Juízes dos processos civis tomem decisões contrárias às decisões dos Juízes criminais, mas a legislação norueguesa já permite que as vítimas possam intentar um processo civil autónomo, mesmo que que o arguido tenha sido absolvido." 
(McGoldrick, Dominic and Others;2004; p.320) Face ao exposto, o TPIJ e o TPIR caracterizam as vítimas de duas formas: as vítimas não podem ser parte nos procedimentos criminais e não podem obter indemnizações pelos danos sofridos. A primeira prerrogativa é exercida pelo Procurador, que representa os interesses da comunidade internacional (incluindo as vítimas). A segunda recai nas jurisdições dos tribunais nacionais. (Cassese, A. and Others; 2002; pp. 1387-1388)

Neste contexto, é importante analisar como é que se podem conciliar os deveres do Procurador, os direitos dos arguidos e a legitimidade das vítimas. (Cassese, A. and Others; 2002; pp.1389) A justiça dos processos inclui o respeito pelos direitos processuais do Procurador, da defesa e das vítimas como se encontram garantidos no Estatuto de Roma. (Tochilousky, Vladimir; 2008; p. 520)

Face ao exposto, parece-nos que os Juízes do TPI terão competência para conhecer todas as questões, inclusive as de natureza civil.

Esta novidade é, a nosso ver, um salto qualitativo gigantesco do TPI. Este reconhecimento é algo que a nós nos pareceria inevitável e hoje a sua concretização é uma realidade em progresso. Esta característica dos sistemas inquisitórios permite um reconhecimento do sofrimento da vítima, o que é fundamental para a paz internacional nos dias de hoje. Este é um passo muito importante para a realização da justiça internacional.

\section{O Papel das Vítimas no Tribunal Militar Internacional e no Tribunal Militar Internacional para o Extremo Oriente}

A questão sobre o papel das vítimas não se coloca no âmbito destes Tribunais. Aqui o mais importante foi dar o primeiro passo para se julgarem internacionalmente os grandes criminosos. Daí que os procedimentos não englobassem um papel fundamental para as vítimas, porque os Procuradores procuravam representar a justiça internacional.

\section{O Papel das Vítimas no Tribunal Penal Internacional para a Ex-Jugoslávia (TPIJ) e no Tribunal Penal Internacional para o Ruanda (TPIR)}

Nestes Tribunais atribuiu-se ao Procurador a tarefa de representar as vítimas em todas as fases do processo, deixando para os Tribunais nacionais a função de atribuir as indemnizações ${ }^{3}$.

3 Regra 106 do Regulamento Processual de ambos os Tribunais. 
As vítimas não têm uma participação ativa no processo, não lhes são reconhecidos quaisquer direitos especiais de participação no julgamento ou de se poderem dirigir diretamente ao Tribunal. Isto significa, que não têm direito a dirigir-se ao Tribunal para se manifestar sobre a concessão da liberdade provisória do arguido, nem para se pronunciar sobre factos relevantes para a pena a atribuir ao arguido. (Boas, Gideon and Others;2011; p. 309)

Todavia, este sistema ignora o facto de que a vítima que pessoalmente participe no processo pode desempenhar um papel fundamental na descoberta da verdade. Mas, mais do que isto, a possibilidade de uma vítima participar no processo e obter uma indemnização pode ajudar a recuperar a sua dignidade, contribuindo para a restauração da paz nos territórios envolvidos.(Cassese, A. and Others; 2002; p. 1389)

Estes Tribunais focaram-se sobretudo na proteção das vítimas. Os Estatutos e os seus Regulamentos Processuais não preveem o direito de as vítimas participarem no processo.

Durante o julgamento, as vítimas só podem ser ouvidas como testemunhas da acusação ou da defesa e estão sujeitas a cumprir uma série de requisitos, designadamente, não podem recusar-se a testemunhar, sob pena de serem penalizadas pelo Tribunal; têm de fazer o juramento de só dizerem a verdade, tendo em conta que se existir perjúrio podem ser processadas; não podem exigir a presença de um advogado; não têm direito a ter acesso às provas apresentadas por qualquer das partes; não podem solicitar ser informadas do andamento do processo, mesmo quando lhes diga diretamente respeito e, por último, não podem estar presentes quando outras testemunhas estejam a prestar depoimento.(Cassese, A. and Others; 2002; p. 1390-1391)

Neste Tribunais as vítimas são chamadas a testemunhar, principalmente, se as suas declarações corroborarem as provas apresentadas pela acusação. (Commentary Marc Groenhuijsen and Anne-Marie Brouwer. In Klip, Andre and Sluiter, Göran; 2010 ICC; p. 273)

O fundamento utilizado para justificar esta situação, menos participativa das vítimas nos Tribunais Ad Hoc, era o facto de se considerar que a atuação dos Procuradores seria suficiente para garantir a proteção dos interesses da comunidade internacional, incluindo aqui os direitos das vítimas.(Commentary Marc Groenhuijsen and Anne-Marie Brouwer. In Klip, Andre and Sluiter, Göran; 2010 ICC; p. 273)

Não obstante o regime apresentado, os Estatutos do TPIJ e do TPIR prevêem formas de reparação dos danos sofridos pelas vítimas. O art. $24 .^{\circ}$, n. ${ }^{\circ} 3$, do Estatuto do TPIJ, e o art. $23 .^{\circ}$, n. ${ }^{\circ}$ 3, do Estatuto do TPIR, preveem a restituição das propriedades que o arguido tenha adquirido ilegalmente. Perante este preceito, sempre que o Tribunal considere que a apropriação indevida da propriedade está relacionado com o crime pelo qual o arguido foi condenado, deve ordenar a sua restituição. 
Esta experiência demonstrou que "nem sempre os interesses da acusação coincidem com os interesses das vítimas" (Commentary Marc Groenhuijsen and Anne-Marie Brouwer. In Klip, Andre and Sluiter, Göran; 2010 ICC; p. 273) e por conseguinte no TPI verificou-se a necessidade de proteger os seus interesses, como veremos no ponto seguinte.

Este sistema adotado pelos magistrados do TPIJ e do TPIR respeita o sistema adversarial, no qual o papel das vítimas é o de testemunhas de alguma das partes e, em princípio, não podem reclamar pela reparação dos danos sofridos. (Cassese, A. and Others; 2002; pp. 1390-1391)

\section{O Papel das Vítimas no Tribunal Penal Internacional (TPI)}

Ao contrário do que sucede nos Tribunais Ad Hoc, no TPI as vítimas têm direitos de participação nos procedimentos com o objetivo de prosseguirem os seus interesses pessoais.

De acordo com o art. $19 .^{\circ}$, n. ${ }^{\circ}$, do Estatuto de Roma, as vítimas podem apresentar as suas observações ao Tribunal sobre as questões de jurisdição e admissibilidade.

Para além disso, o TPI admite a participação das vítimas nos procedimentos, permitindo que as vítimas sejam representadas por um advogado e que tenham uma voz ativa durante o julgamento. (Jouet, Mugambi; Artigo 2007; p. 1)

As vítimas dos crimes que se encontram sob a jurisdição do TPI têm algumas necessidades que pretendem ver compensadas: "(1) Receber uma compensação pelos danos sofridos; (2) Verificar que o criminoso foi punido; (3) Ter um local onde possam falar e ser ouvidas; Conhecer a verdade sobre as questões políticas que provocaram os danos que lhes foram infligidos." (Jouet, Mugambi; Artigo 2007; p. 1e 2)

A análise a fazer vai no sentido de conhecer as previsões do Estatuto de Roma sobre o papel das vítimas, nomeadamente, sobre as suas possíveis intervenções durante as diferentes fases do processo.

Esta situação não tem precedentes na justiça internacional e por conseguinte o TPI irá enfrentar os desafios inerentes à participação das vítimas nos procedimentos criminais. Todavia, o TPI poderá recorrer à prática das jurisdições nacionais para articular da melhor forma a participação das vítimas. (Commentary Marc Groenhuijsen and Anne Marie de Brouwer. In Klip, Andre and Sluiter, Göran; 2010 ICC; p. 274)

"O TPI deve garantir que a participação de um grande número de vítimas nos procedimentos, não afetará a realização de um julgamento justo, imparcial e célere". (Commentary Marc Groenhuijsen and Anne Marie de Brouwer. In Klip, Andre and Sluiter, Göran; 2010 ICC; p. 274)

Nos procedimentos do TPI, as vítimas têm direito a tomar parte nos processos, a serem informadas sobre os desenvolvimentos dos processos e a obterem a reparação dos seus pre- 
juízos. A definição de vítima encontra-se na Regra 85 do Regulamento Processual do TPI. O Tribunal de Recurso do TPI teve ocasião de definir quem pode ser qualificado como vítima para poder intervir nos procedimentos, bem como, determinar a abrangência da sua participação nos processos, quer na fase de investigação, quer na fase de julgamento. O Tribunal de Recurso decidiu, por unanimidade, que um indivíduo pode ser considerado uma vítima conforme a Regra 85, se tiver sofrido um dano direto ou de forma indireta. ${ }^{4}$ Ficou também decidido que os danos sofridos têm de estar relacionados com os crimes de que o arguido é acusado. Só satisfeitos estes pressupostos é que as vítimas poderão participar no processo. (Karim, Khan and Others; 2010; p. 543)

A interpretação do art. $68 .^{\circ}$, n. ${ }^{\circ}$ 3, do Estatuto de Roma ${ }^{5}$ é aplicável à fase de investigação, mas é também consistente e logo aplicável a todas as fases do processo. (Tochilovsky, Vladimir; 2008; p. 519. McGoldrick, Dominic and Others; 2004; p. 322) Contudo, a participação das vítimas está sujeita a alguma discricionariedade judicial. Os Juízes determinarão não só se os interesses pessoais das vítimas são afetados, mas também se a fase é a apropriada à intervenção das vítimas. (McGoldrick, Dominic and Others; 2004; p. 323) No caso Lubanga, cumprindo a previsão do art. 68. ${ }^{\circ}$, n. ${ }^{\circ}$ 3, do Estatuto de Roma, as vítimas participaram ativamente no caso e solicitaram a apresentação de prova, questionaram as testemunhas e avançaram com uma série de observações orais e escritas com a permissão do Tribunal e com a colaboração dos seus representantes legais. Foram autorizadas a participar nos procedimentos 129 vítimas (34 mulheres e 95 homens). Três dos depoimentos das vítimas não foram valorados pelo Tribunal por falta de credibilidade e foi-lhes retirada a autorização anteriormente concedida pelo Tribunal de participarem nos procedimentos. ${ }^{6}$

O Estatuto de Roma garante às vítimas uma voz independente e um papel nos procedimentos. (Tochilovsky, Vladimir; 2008; p. 519) ${ }^{7}$

Todavia, as modalidades de participação das vítimas nos procedimentos devem garantir que não são prejudiciais ou inconsistentes com os direitos da defesa. Nestas circunstâncias, o Tribunal pode nomear um advogado ad hoc para representar os interesses da defesa. ${ }^{8}$

\footnotetext{
4 Prosecutor v. Thomas Lubanga Dyilo; ICC-01/04-01/06, 11 July 2008, §§ 38-39.

$5 \mathrm{O}$ art. $68 .^{\circ}$, n. $^{\circ}$ 3, do Estatuto de Roma refere que: «Se os interesses pessoais das vítimas forem afetados, o Tribunal permitir-lhes-á que expressem as suas opiniões e preocupações em fase processual que entenda apropriada e por forma a não prejudicar os direitos do arguido nem a ser incompatível com estes ou com a realização de um julgamento equitativo e imparcial».

6 Prosecutor v. Thomas Lubanga Dyilo, Case No. ICC-01/04-01/06, 14 March 2012, pp. 3, 4 e 5.

7 Situation in the Democratic Republic of the Congo, Case No. ICC-01/04, 17 January 2006; §§ 50 e 51. In Tochilovsky, Vladimir; 2008; p. 519.

8 Idem, § 70. In Tochilovsky, Vladimir; 2008; p. 521.
} 
Quando o Juízo de Instrução tomar oficiosamente medidas, conforme o art. 56. ${ }^{\circ}$, n. $^{\circ} 3$, al. a), e $57 .^{\circ},{ }^{\circ} 3$, al. c), do Estatuto de Roma, deve decidir se as vítimas devem participar no processo, tendo em conta os seus interesses pessoais. ${ }^{9}$

O desafio é conciliar os direitos dos arguidos e das vítimas, direitos que são, só por si, conflituantes. No intuito de concretizar este propósito, Mugambi Jouet apresenta duas hipóteses: a realização de uma interpretação adequada das normas sobre a participação das vítimas nos procedimentos ou a sua alteração. A primeira situação a definir é a interpretação do art. $6 .^{\circ}$, n. $^{\circ} 3$, no sentido de saber quando é que as vítimas devem integrar os procedimentos. Assim, as vítimas não devem integrar os procedimentos até que esteja provado que são vítimas. (Jouet, Mugambi; Artigo 2007; p. 12) Segundo este autor, a solução será interpretar esta norma da forma mais adequada ao desenvolvimento dos procedimentos, porque a possível alteração da norma seria algo quase impossível de realizar, visto que isso significaria ainda mais garantias para os arguidos. Perante este facto, a oposição a uma possível alteração inviabilizaria qualquer tentativa nesse sentido.

No que diz respeito a saber se as vítimas podem participar na fase de recurso, é mais uma vez importante conhecer os seus interesses pessoais. As vítimas poderiam recorrer das decisões que autorizassem ou recusassem a libertação da pessoa objeto de inquérito ou de procedimento criminal, de acordo com o art. 82..$^{\circ}$ n..$^{\circ}$ 1, al. b) do Estatuto de Roma. Para que o Tribunal de Recurso admita a participação das vítimas, é necessário que elas façam uma declaração sobre se e como é que os seus interesses pessoais são afetados pelo recurso, bem como porque é que a participação das vítimas é apropriada. ${ }^{10}$ Esta questão é polémica porque Claude Jorda e Jérôme de Hemptinne referem que as vítimas não têm direito ao recurso contra o arguido. Permitam-nos discordar, porque consideramos que as vítimas devem ter direito a recorrer em conjunto com a acusação contra o arguido se os seus interesses pessoais forem afetados e se isso contribuir para a justiça internacional.

Para além disto, compete ao Tribunal decidir se as vítimas têm ou não direito à indemnização. Para o fazer, deve possuir certas informações, incluindo a descrição do prejuízo, da perda ou do dano, bem como conhecer o local e a data do incidente. Portanto, todos os documentos relativos a esta questão devem ser anexados, incluindo os nomes e as moradas das testemunhas. (Cassese, A. and Others; 2002; pp. 1406-1407) O Tribunal de 1. ${ }^{\mathrm{a}}$ Instância do TPI permitiu que as vítimas participem através de representação legal que elucide as provas apresentadas. (Cassese, A. and Others; 2002; pp. 1407-1408) Esta reparação às vítimas deve ser feita pelo indivíduo condenado, e apenas se lhe for impossível ou impraticável se deverá

9 Idem, § 73. In Tochilovsky, Vladimir; 2008; p. 521.

10 Prosecutor v. Thomas Lubanga Dyilo, Case No. ICC-01/04-01/06, 13 February 2007, §§ 38 a 45. In Tochilovsky, Vladimir; 2008 ; p. 522. 
recorrer ao Fundo a favor das vítimas, previsto no art. $79 .^{\circ}$ do Estatuto de Roma. (Cassese, A. and Others; 2002; pp. 1407-1408)

Apesar do reconhecimento de todos estes direitos, as vítimas não têm os mesmos direitos das outras partes. Não devem participar nas investigações realizadas pelo Procurador, não têm acesso às provas apresentadas pelas partes nem podem chamar testemunhas a depor.

O Tribunal tem ainda muito trabalho para fazer, apesar de todas as garantias referidas. A primeira questão que deve ser esclarecida é o papel das vítimas durante a fase de investigação, considerando que esta questão não é clara, nem decorre do Estatuto ou dos Regulamentos Processuais. Por outro lado, o Regulamento Processual ainda não definiu formas para que as vítimas possam estar presentes nos procedimentos. As Regras Processuais também não definem se uma das partes pode chamar uma vítima a intervir nos procedimentos como testemunha. Em ordem a salvaguardar os direitos do arguido, é necessário garantir que uma vítima não seja, ao mesmo tempo, uma testemunha. É preciso equilibrar o direito do arguido a ter um julgamento célere com os direitos das vítimas. É também importante dividir o processo em duas fases, uma para a acusação e defesa e outra para as vítimas. (Cassese, A. and Others; 2002; pp. 1409-1417)

A 7 de agosto de 2012, no caso Thomas Lubanga Dyilo" ${ }^{11}$ o Tribunal de 1. ${ }^{\text {a }}$ Instância decidiu estabelecer os princípios aplicáveis às formas de reparação, tais como a restituição, a indemnização ou a reabilitação que decorrem do art. $75 .^{\circ}$, n. ${ }^{\circ}$ 1, do Estatuto de Roma. Pela primeira vez, o Tribunal reconheceu que o Estatuto de Roma e o seu Regulamento Processual apresentam um sistema de reparação que, crescentemente, reconhece a necessidade de a justiça criminal internacional ir para além do que é a justiça punitiva. ${ }^{12}$ Caminhamos para uma justiça mais inclusiva, em que se encoraja a participação das vítimas e se reconhece a necessidade de reparação dos direitos das vítimas. Neste caso, o Tribunal concluiu que «a reparação das vítimas deveria minimizar o sofrimento infligido e as consequências que daí advieram, bem como, impedir violações futuras e contribuir para a efetiva reintegração das crianças soldado». ${ }^{13}$ Para além disso, a reparação deve ser feita de forma flexível, por forma a garantir «a maior reparação possível das violações dos direitos das vítimas.» ${ }^{14}$

Com fundamento na Regra 85 do Regulamento Processual, o Tribunal considerou que a reparação deve ser para as vítimas que sofreram danos de forma direta, mas também para

\footnotetext{
11 Prosecutor v Thomas Lubanga Dyilo; Case No. ICC-01/04-01/06; Decision Trial Chamber, 7 August 2012.

12 Idem, § 177.

13 Idem, § 179.

14 Idem, § 180 .
} 
as que sofreram de forma indireta, incluindo os familiares das vítimas. ${ }^{15}$ Neste caso, o Tribunal definiu que as indemnizações deveriam ser garantidas pelo Fundo sob fiscalização do Tribunal. Importa ainda referir dois outros critérios presentes nesta Regra, que é o facto de os crimes em causa estarem sujeitos à jurisdição do TPI e também o nexo de causalidade entre o crime praticado e o dano sofrido. ${ }^{16}$

No caso Thomas Lubanga Dyilo, o Tribunal, na fase de investigação, reconheceu seis pessoas como vítimas. Contudo, a 29 de junho de 2006, o Juízo de Instrução rejeitou a participação dessas pessoas como vítimas, porque os crimes que elas sofreram não coincidem com os crimes de que o arguido é acusado. ${ }^{17}$ Um mês depois, a 28 de julho de 2006, o Tribunal reconsiderou e reconheceu como vítimas três das pessoas anteriormente rejeitadas, porque eram parentes de crianças que tinham sido obrigadas a alistar-se na milícia alegadamente chefiada por Thomas Lubanga Dyilo. ${ }^{18-19}$

Uma das decisões mais controversas do Tribunal foi a permissão concedida a algumas vítimas de poderem participar nos procedimentos sob anonimato. ${ }^{20} \mathrm{O}$ Tribunal enfrentou o dilema de ter de harmonizar os direitos do arguido com a necessidade de proteger as vítimas da intimidação, ameaça ou possíveis danos. ${ }^{21} \mathrm{O}$ Tribunal não permitiu que fossem conhecidas as identidades das vítimas, conforme a Regra 87. Para cumprir esta exigência todas as informações que pudessem conduzir à identificação das vítimas foram retiradas dos documentos revelados à defesa.

A defesa protestou veementemente contra esta situação afirmando que deveria conhecer a identidade quem pretendia receber indemnizações. Para fundamentar esta pretensão utilizou vários argumentos: (1) as medidas de proteção eram medidas extraordinárias, que eram injustificadas naquelas circunstâncias; (2) esse facto levou à formulação de acusações anónimas impróprias; (3) as informações nos documentos eram muito vagas, porque omitiam a idade das vítimas no momento da prática do alegado crime; (4) uma defesa não pode ser bem organizada se não conhecer todos os elementos referentes à identidade das vítimas; (5) a informação omitida pode ser prova ilibatória, por exemplo não existir nexo de causalidade com os crimes em acusação; (6) o direito do arguido a ser julgado de forma célere pode ser posto em causa por a defesa ter de prolongar a sua análise devido às infor-

15 Idem, § 194.

16 Prosecutor v. Thomas Lubanga Dyilo, Case No. ICC-01/04-01/06, 17 January 2006; §§ 77-94.

17 Prosecutor v. Thomas Lubanga Dyilo, Case No. ICC-01/04-01/06, 29 June 2006; pp. 8-9.

18 Prosecutor v. Thomas Lubanga Dyilo, Case No. ICC-01/04-01/06, 28 July 2006. Vd.

19 Vd. Commentary Marc Groenhuijsen and Anne Marie de Brouwer. In Klip, Andre and Sluiter, Göran; 2010 ICC; p. 276.

20 Vd. Prosecutor v. Thomas Lubanga Dyilo; ICC-01/04-01/06-437, Decision Trial Chamber I, 19 September 2006 e Decision 20 September 2006.

21 Prosecutor v. Thomas Lubanga Dyilo; ICC-01/04-01/06-437, Decision Trial Chamber I, 15 September 2006, p. 8. 
mações omitidas; (7) a acusação beneficiar de informações que a defesa desconhece viola o direito à igualdade de armas e a um julgamento justo; e (8) a regra 87 não prevê que a identidade das vítimas não seja revelada à defesa, mas sim à comunicação social, ao público e a agências de informações, porque as medidas de segurança devem estar subordinadas aos direitos dos arguidos. ${ }^{22}$

O Tribunal sustentou que o privilégio do anonimato acarreta um limite à participação das vítimas, porque estas não poderão acrescentar factos ou provas à acusação formulada contra o arguido. ${ }^{23}$

Esta intervenção das vítimas nos procedimentos está relacionada com a prática dos sistemas da Civil Law.

Em síntese, o sistema adoptado pelo TPI é híbrido, mas sobressaem características dos sistemas da Civil Law. Todavia, apresentadas as lacunas que ainda estão por clarificar, tendemos a concluir que ainda não estamos perante um sistema totalmente fiel aos sistemas da Civil Law, sendo por isso, sui generis.

\section{Conclusão}

O papel das vítimas no direito português, bem como, no direito internacional denota uma evolução muito significativa nos Tribunais Penais Internacionais. Inicialmente, no TMI e no TMIEO a possibilidade de reparação dos danos sofridos pelas vítimas era uma questão que nem se colocava e, hoje, temos o TPI a decidir sobre estas matérias. Entre este espaço temporal, os Tribunais Ad Hoc consideravam que as vítimas se encontravam representadas pelo Procurador.

Os desenvolvimentos desta questão aproximam-no dos sistemas da Civil Law, sendo as vítimas partes nos processos e tendo direito à reparação dos danos sofridos. Esta situação é diferente da que sucede nos sistemas da Common Law em que as vítimas são apenas testemunhas nos processos.

Sintetizando, a participação das vítimas do TPI é uma realidade, tendo adquirido preponderância nos procedimentos criminais. Embora, o sistema adotado pelo TPI se aproxime da prática dos sistemas da Civil Law, consideramos que estamos perante um sistema jurídico-criminal único.

Hoje, em Portugal, esperamos "caminhar a passos largos" para as posições reconhecidas e respeitadas internacionalmente.

22 Prosecutor v. Thomas Lubanga Dyilo; ICC-01/04-01/06-437, Decision Trial Chamber I, 4 September 2006, pp. 7-10.

23 Prosecutor v. Thomas Lubanga Dyilo; ICC-01/04-01/06-437, Decision Trial Chamber I, 22 September 2006, p. 7. 


\section{BIBLIOGRAFIA}

\section{Bassiouni, M. Cherif}

2005 The Legislative History of the International Criminal Court: Article-by-Article Evolution of the Statute; Vol. 2. Ardsley, New York; Transnational Publishers, Inc.

Boas, Gideon; Bischoff, James L.; Reid, Natalie L. and Taylor III, B. Don

2011 International Criminal Law Practitioner Library Series, Volume III. Cambridge University Press Cassese, Antonio; Gaeta, Paola and Jones, Jonh R. W. D.:

2002 The Rome Statute of the International Criminal Court: A Commentary: Materials, Volume I and II. New York, Oxford University Press.

\section{Jouet, Mugambi}

2007 Reconciling the Conflicting Rights of Victims and Defendants at the Internacional Criminal Court. In Saint Louis University Public Law Review, 249

Lee, Roy $S$.

2001 The International Criminal Court: The Making of the Rome Statute: Issues, Negotiations and Results. The Netherlands, Kluwer Law International

\section{Macgonigle, Brianne N.}

2009 Bridging the Divides in International Criminal Proceedings: an Examination into the Victim Participation Endeavor of the International Criminal Court. Copyright (c) 2009 Florida Journal of Interntional Law 93.

Mcgoldrick, Dominic; Rowe, Peter and Donnelly, Eric

2004 The Permanent International Criminal Court: Legal and Policy Issues. Oxford, Hart Publishing. Khan, Karim A. A.; Buismen, Caroline and Gosnell, Christopher

2010 Principles of Evidence in International Criminal Justice. Oxford University Press.

\section{Klip, André and Sluiter, Göran}

2010 Annotated Leading Cases of International Criminal Tribunals. The International Criminal Tribunals, Intersentia, André Klip and Göran Sluiter Eds.

2010 Annotated Leading Cases of International Criminal Tribunals. The International Criminal Tribunal for Rwanda 2006-2007. Intersentia, André Klip and Göran Sluiter Eds.

\section{Tochilovsky, Vladimir}

2008 Jurisprudence of the International Criminal Courts and the European Court of Human Rights. Leiden/Boston, Martinus Nijhoff Publishers.

\section{Triffterer, Otto}

2008 Commentary on the Rome Statute of the International Criminal Court, Observers' Notes, Article by Article. Munich Germany. Nomos Verlagsgesellschaft Baden-Baden.

\section{JURISPRUDÊNCIA}

Thomas Lubanga Dyilo (ICC-01/04-01/06)

Judgment on the Appeal of Prosecutor and the Defence Against Trial Chamber I's Decision on Victim's Participation of 18 January 2008; Majority Opinion, 11 July 2008

Prosecution's Application to Lift the Stay of Proceedings, 11 July 2008

Judgment Hearing, 14 March 2012

Decision Establishing the Principles and Procedures to be Applied to Reparations, 7 August 2012

Decision on the Applications for Participation in the Proceedings Submitted by VPRS 1 to VPRS 6 in the Case the Prosecutor v. Thomas Lubanga Dyilo, 29 June 2006 
Decision on the Applications for Participation in the Proceedings of a/0001/06, a/0002/06 and a/0003/06 in the case of the Prosecutor v. Thomas Lubanga Dyilo and of the investigation in the Democratic Republic of the Congo, 28 July 2006

Defence Observations Relative to the Proceedings and Manner of Participation of Victims a/oool/06 to a/ooo3/o6, 4 September 2006

Second Decision on the Prosecution Requests and Amended Requests for Redactions under Rule 81, 20 September 2006

Decision on the Arrangements for Participation of Victims a/0001/06, a/0002/06 and a/0003/06 at the Confirmation Hearing, 22 September 2006 - p. 229 


\title{
Oralidad y litigio en América Latina. Principales hallazgos de un estudio empírico ${ }^{1}$
}

\author{
LEONEL GONZÁLEZ ${ }^{2}$ \\ leonel.gonzalez@cejamericas.org \\ MARCO FANDIÑO ${ }^{3}$ \\ marco.fandino@cejamericas.org
}

GALILEU - REVISTA DE DIREITO E ECONOMIA - e-ISSN 2184-1845

Volume XX $\cdot 1^{\text {st }}$ July Julho $-31^{\text {TH }}$ December Dezembro $2019 \cdot$ pp. 61-83

DOI: http://doi.org/10.26619/2184-1845.XX.2.4

Submitted on October $8^{\text {th }}, 2019 \cdot$ Accepted on November 15 th $^{\text {t }} 2019$

Submetido em 8 de Outubro, 2019 - Aceite a 15 de Novembro, 2019

RESUMEN Desde una perspectiva comparada, en este artículo se analizan algunos de los aspectos más relevantes relacionados con la calidad del funcionamiento de la oralidad en los sistemas penales adversariales en 19 países de América Latina. En base a evidencia empírica, se analiza comparativamente cómo se ha regulado la oralidad y cuáles son las principales audiencias existentes en la práctica; cómo funcionan la oralidad y la litigación y si estas permiten obtener información de mayor calidad y, finalmente, cuál es el nivel de avance del instituto del juicio por jurados.

PALABRAS ClaVE Oralidad, Litigación, Juicio por Jurados, Sistema Penal Acusatorio, Justicia Adversarial

ABSTRACT From a comparative perspective, this article analyzes some of the most relevant aspects related to the quality of the litigation in adversarial criminal systems in 19 Latin American countries. Based on empirical evidence, it is comparatively analyzed how orality has been regulated and what are the main hearings in practice; how orality and litigation work and if these allow obtaining higher quality information and, finally, what is the level of progress of the jury trial institute.

KEYworDS Orality, Litigation, Trial by Juries, Adversarial Criminal System

\footnotetext{
1 Este trabajo está basado en el estudio "La justicia penal adversarial en América Latina. Hacia la gestión del conflicto y la fortaleza de la ley", CEJA y Fundación KAS, 2018, disponible en: www.cejamericas.org

2 LLM en Derecho Penal y Procesal Penal (Osgoode, Canadá), Director de Capacitación (CEJA).

3 Máster en Gobernanza y Derechos Humanos (UAM, España), Director de Estudios y Proyectos (CEJA).
} 


\section{Introducción}

Este artículo sintetiza los principales hallazgos del informe: "La Justicia Penal Adversarial en América Latina. Hacia la gestión del conflicto y la fortaleza de la ley" (CEJA, 2018), un estudio empírico realizado entre el Centro de Estudios de Justicia de las Américas y la Fundación Konrad Adenauer. El ámbito del estudio fueron 19 países de América Latina, incluyendo varias jurisdicciones en aquellos países federales como Argentina, Brasil y México. El principal objetivo del estudio fue realizar un diagnóstico del estado de situación de la justicia penal adversarial, tras haberse finalizado la instalación del sistema penal acusatorio en casi todos los países hispanohablantes de la región.

Para ello, se identificaron autores y autoras locales que pudiesen hacer un levantamiento de información basado en aspectos cualitativos de vital interés para la investigación como, por ejemplo, la calidad de la litigación oral en la celebración de las audiencias. Dicha información es extraída de entrevistas a operadores del sistema de justicia o a especialistas con un conocimiento profundo sobre estas materias.

En este artículo ofrecemos una visión panorámica del estado de situación de los sistemas procesales penales en los siguientes ámbitos: a) Los diversos tipos de audiencias reguladas, indicando los principales objetivos de las mismas así como anomalías en el uso de las audiencias para fines distintos a los provistos normativamente; b) La calidad de la oralidad, esto es, si la litigación de las partes permite generar información de alta calidad en las audiencias; c) la regulación del juicio por jurado como uno de los elementos centrales en la recuperación de la esencia del modelo de enjuiciamiento adversarial previsto en la mayoría de las constituciones latinoamericanas.

\section{Oralidad, calidad de la litigación y juicio por jurados}

\section{2. a. La estructura procesal del sistema adversarial}

Uno de los ejes rectores en la instalación del sistema adversarial estuvo dado por la sustanciación del proceso a través de audiencias orales, públicas y contradictorias. Particularmente, este modelo reposa en tres etapas procesales principales: la judicialización del caso (formalización de la investigación) para aquellos supuestos en los que el Ministerio Público tome la decisión de iniciar una persecución penal en contra del imputado; el control de la acusación (etapa intermedia) para poner en discusión la labor de investigación que ha hecho el fiscal y decidir si ésta reúne mérito para habilitar un juicio; y el debate oral y público (fase de juicio) para aquellos casos que no hayan podido ser resueltos mediante una salida alternativa y solamente puedan dirimirse mediante la producción de prueba. Aunque esta es la base procesal, 
el modelo adversarial se funda en que todos los planteos de las partes y todas las decisiones jurisdiccionales deben tomarse por regla en el marco de una audiencia.

Si bien la oralidad se saldó legalmente en la etapa de juicio (pues todos los países cuentan con una audiencia), aún subsiste la necesidad de consolidarla en la etapa preliminar en tanto las realidades locales demuestran que, en general, las audiencias previas no están reguladas o funcionan débilmente. En la siguiente tabla se halla la información sobre las audiencias orales reguladas en los códigos procesales penales de la región.

Tabla 2. Audiencias orales reguladas en los Códigos Procesales Penales de América Latina ${ }^{4}$

\begin{tabular}{|c|c|c|c|c|c|}
\hline PAís & $\begin{array}{l}\text { CONTROL DE } \\
\text { DETENCIÓN5 }\end{array}$ & $\begin{array}{l}\text { FORMULACIÓN DE } \\
\text { IMPUTACIÓN }\end{array}$ & $\begin{array}{l}\text { MEDIDAS } \\
\text { CAUTELARES }\end{array}$ & $\begin{array}{l}\text { SALIDAS } \\
\text { ALTERNATIVAS Y } \\
\text { ABREVIADO }\end{array}$ & $\begin{array}{l}\text { ETAPA } \\
\text { INTERMEDIA }\end{array}$ \\
\hline Argentina (Federal) 6 & Si (72 horas) & $\mathrm{Si}$ & $\mathrm{Si}$ & $\mathrm{Si}$ & $\mathrm{Si}$ \\
\hline Argentina (Neuquén) & Si (24 horas) & $\mathrm{Si}$ & Si & $\mathrm{Si}$ & $\mathrm{Si}$ \\
\hline Bolivia & $\mathrm{No}^{7}$ & No & Si & Si & No \\
\hline Brasil (Federal) $^{8}$ & \multirow{2}{*}{ Si (24 horas) } & \multirow{2}{*}{ No } & \multirow{2}{*}{$\mathrm{Si}$} & \multirow{2}{*}{ No } & \multirow{2}{*}{ No } \\
\hline Brasil (Bahía) & & & & & \\
\hline Chile & Si (24 horas) & $\mathrm{Si}$ & $\mathrm{Si}$ & $\mathrm{Si}$ & $\mathrm{Si}$ \\
\hline Colombia & Si (36 horas) & $\mathrm{Si}$ & Si & Si & $\mathrm{Si}$ \\
\hline Costa Rica & No & No & $\mathrm{Si}^{9}$ & No & $\mathrm{Si}$ \\
\hline Cuba & No & No & No & No & No \\
\hline
\end{tabular}

4 En este gráfico se alude a la regulación legal de las audiencias; se hará una nota explicativa en aquéllos casos en los cuales las audiencias se realicen en la práctica judicial sin estar necesariamente reguladas.

5 En esta columna, en los casos que corresponda, entre paréntesis se indicará el plazo máximo que regulan los ordenamientos procesales entre la detención y la realización de la audiencia de control de detención.

6 Se consignan las audiencias reguladas en el CPP sancionado en diciembre de 2014 y vigente desde junio de 2019 en la justicia federal de las provincias de Salta y Jujuy.

7 El artículo 226 del CPP de Bolivia solo prevé que la persona aprehendida por la policía o la fiscalía sea puesta a disposición de la autoridad judicial, en el plazo de veinticuatro horas, para que la misma resuelva, dentro del mismo plazo, sobre la aplicación de alguna medida cautelar o decrete su libertad por falta de indicios. El informe local de Bolivia indica que "no se realiza una audiencia de control de la detención, pero tampoco se hace el control por escrito. Como en la mayoría de los casos se cumplen los plazos, es decir que la policía o fiscalía pone el detenido a disposición del juez en 24 horas, todos los casos pasan directamente a la audiencia de solicitud de medida cautelar. En los casos en los que los plazos no se cumplieron, la defensa plantea un incidente por ilegalidad de la aprehensión - por actividad procesal defectuosa e inobservancia o violación de derechos y garantías (artículo $169 .^{\circ}$ ) - durante la audiencia cautelar, pero considerando que en la mayoría de los casos el juez determina la detención preventiva y entonces la detención se torna legal".

8 En Brasil rige un único Código Procesal Penal tanto para la justicia federal como para los Estados.

9 El informe de Costa Rica indica que "parte de la conquista llevada a cabo a través de la capacitación iniciada en el año 2004 (...) fue hacer conciencia en los jueces, defensores y fiscales sobre la necesidad de hacer real el derecho a ser escuchado antes de tomar una decisión tan delicada como es una prisión preventiva. No fue sino hasta el año 2009, mediante la Ley de Protección de Víctimas, Testigos y demás sujetos intervinientes en el Proceso Penal que se reformó la ley para prever la celebración de una audiencia en los casos en que fuera solicitada una prisión preventiva". Es decir, que se trató de un cambio que surgió desde la práctica. 


\begin{tabular}{|c|c|c|c|c|c|}
\hline PAís & $\begin{array}{l}\text { CONTROL DE } \\
\text { DETENCIÓN5 }\end{array}$ & $\begin{array}{l}\text { FORMULACIÓN DE } \\
\text { IMPUTACIÓN }\end{array}$ & $\begin{array}{l}\text { MEDIDAS } \\
\text { CAUTELARES }\end{array}$ & $\begin{array}{l}\text { SALIDAS } \\
\text { ALTERNATIVAS Y } \\
\text { ABREVIADO }\end{array}$ & $\begin{array}{l}\text { ETAPA } \\
\text { INTERMEDIA }\end{array}$ \\
\hline Ecuador & Si (24 horas) & $\mathrm{Si}$ & $\mathrm{Si}$ & $\mathrm{Si}^{10}$ & $\mathrm{Si}$ \\
\hline El Salvador & No & No"1 & $\mathrm{Si}$ & Si & $\mathrm{Si}$ \\
\hline Guatemala & Si (24 horas) & $\mathrm{Si}$ & $\mathrm{Si}$ & Si & $\mathrm{Si}^{12}$ \\
\hline Honduras & Si $(24 \text { horas })^{13}$ & No & $\mathrm{Si}$ & $\mathrm{Si}$ & $\mathrm{Si}^{14}$ \\
\hline México (Federal) ${ }^{15}$ & \multirow{2}{*}{ Si (48 horas) ${ }^{16}$} & \multirow{2}{*}{$\mathrm{Si}^{17}$} & \multirow{2}{*}{$\mathrm{Si}$} & \multirow{2}{*}{ Si } & \multirow{2}{*}{$\mathrm{Si}$} \\
\hline México (Nuevo León) & & & & & \\
\hline Nicaragua & Si $(48 \text { horas) })^{18}$ & $\mathrm{Si}$ & $\mathrm{Si}$ & $\mathrm{Si}$ & $S i^{19}$ \\
\hline
\end{tabular}

10 Con la entrada en vigencia del Código Orgánico Integral Penal, en Ecuador se derogó la suspensión condicional del procedimiento. En este apartado solo aludimos a la regulación del juicio abreviado.

11 En El Salvador, si bien se estipula que el control de detención, formalización y medidas cautelares se discutan en el marco de una audiencia (la "inicial"), aún la lógica del proceso remite a un sistema tradicional mediante el cual la primera audiencia sirve para tomar declaración indagatoria al imputado y tras ello se habilitan los plazos de investigación (de "instrucción" según la terminología del ordenamiento local).

12 La etapa intermedia del proceso penal en Guatemala se subdivide entre la audiencia intermedia (para discutir acerca del hecho por el que el/la fiscal/a formula acusación y, en su caso, dictar el auto de apertura a juicio) y la audiencia de ofrecimiento de prueba (para discutir sobre los medios de prueba que ofrecen las partes y que serán admitidos para el juicio).

13 Si bien en Honduras está previsto que el/la imputado/a debe ser presentado ante el/la juez/a en un plazo de 24 horas en aquellos casos en los que se encuentre detenido/a, el informe local informa que "una vez que el imputado se encuentra en el Juzgado, se recibe su declaración en una audiencia prevista a dicho efecto. Previo a que se rinda la misma, el juez informa al imputado los hechos que se le imputan en el requerimiento y los derechos que le asisten". Esta dinámica responde a la lógica de la declaración indagatoria del sistema procesal mixto en donde esta etapa es considerada meramente como una instancia formal y de recibimiento de declaración.

14 La etapa intermedia del proceso penal de Honduras consiste en la audiencia preliminar, prevista para la formalización de la acusación, contestación de cargos y el auto de apertura a juicio. La audiencia de preparación del debate (para plantear recusaciones, excepciones o nulidades basadas en hechos nuevos) y la audiencia de proposición de pruebas (para que las partes presenten la lista de medios de prueba indicando los hechos o circunstancias que se pretenden probar con cada uno) se produce en etapa de juicio oral.

15 Aludimos únicamente a la estructura procesal del Código Nacional de Procedimientos Penales, que se encuentra en vigencia tanto en la justicia federal como en todas las Entidades Federativas.

16 En México, "en los casos de detenciones en flagrancia, una vez que la persona detenida es puesta a disposición del Ministerio Público, ya sea por parte de la Policía o de cualquier otra persona, el Ministerio Público cuenta con un plazo de 48 horas para investigar y decidir si pone a la persona detenida a disposición del juez para controlar su detención y resolver sobre su situación jurídica. A dicho plazo de 48 horas se le conoce como "plazo de retención". Si agotado el plazo de retención, el Ministerio Público decide no presentar a la persona detenida ante el juez de control entonces no existe un control judicial de dicha detención. Cabe agregar que el Ministerio Público, durante el plazo de retención, tiene la facultad de poner en libertad a la persona detenida o de imponerle una medida de protección, cuando se trate de delitos que no merezcan prisión preventiva oficiosa y determine que no solicitará la prisión preventiva como medida cautelar, en términos del artículo 140 del CNPP".

17 En México, de forma posterior a la formulación de imputación, el Ministerio Público debe solicitar "la vinculación a proceso" del imputado, lo cual implica discutir sobre los datos de prueba con que cuenta el fiscal para sostener que ha existido un hecho que es delito y que el imputado ha participado en él.

18 En Nicaragua, la discusión sobre el control de detención, formalización (acusación, según la terminología local) y medidas cautelares se produce en el marco de la denominada "audiencia preliminar", regulada entre los artículos 255 a 264 del Código Procesal Penal de Nicaragua.

19 La etapa intermedia del proceso penal en Nicaragua se encuentra desdoblada en dos fases: por un lado, en la audiencia inicial (regulada entre los artículos 265 y 272 del CPP), que tiene como finalidades principales determinar si existe causa para proceder a Juicio e iniciar el procedimiento para el intercambio de las pruebas 


\begin{tabular}{llllll}
\hline PAís & $\begin{array}{l}\text { CONTROL DE } \\
\text { DETENCIÓN5 }\end{array}$ & $\begin{array}{l}\text { FORMULACIÓN DE } \\
\text { IMPUTACIÓN }\end{array}$ & $\begin{array}{l}\text { MEDIDAS } \\
\text { CAUTELARES }\end{array}$ & $\begin{array}{l}\text { SALIDAS } \\
\text { ALTERNATIVAS Y } \\
\text { ABREVIADO }\end{array}$ & $\begin{array}{l}\text { ETAPA } \\
\text { INTERMEDIA }\end{array}$ \\
\hline Panamá & $\mathrm{Si}$ (24 horas) & $\mathrm{Si}$ & $\mathrm{Si}$ & $\mathrm{Si}$ & $\mathrm{Si}$ \\
\hline Paraguay & $\mathrm{No}$ & $\mathrm{No}$ & $\mathrm{Si}$ & $\mathrm{Si}$ & $\mathrm{Si}^{20}$ \\
\hline Perú & $\mathrm{No}^{21}$ & $\mathrm{No}$ & $\mathrm{Si}$ & $\mathrm{Si}$ & $\mathrm{Si}$ \\
\hline República Dominicana & $\mathrm{No}^{22}$ & $\mathrm{No}$ & $\mathrm{Si}$ & $\mathrm{Si}$ & $\mathrm{Si}$ \\
\hline Uruguay & $\mathrm{Si}(24$ horas) & $\mathrm{Si}$ & $\mathrm{Si}$ & $\mathrm{Si}$ & $\mathrm{Si}$ \\
\hline Venezuela & $\mathrm{Si}(48$ horas) & $\mathrm{No}$ & $\mathrm{No}$ & $\mathrm{No}$ & $\mathrm{Si}$ \\
\hline
\end{tabular}

Fuente: Elaboración propia

El diseño de los códigos procesales penales latinoamericanos nos indica que coexisten diversas tendencias en la regulación de la estructura procesal del modelo adversarial. En un ejercicio clasificatorio, podríamos distinguir la existencia de tres tipos distintos de proceso adversarial.

El primero está dado por el llamado proceso adversarial clásico, que consiste en la estipulación de la oralidad como principio general y en un conjunto variado de audiencias para la toma de todas las decisiones jurisdiccionales durante la etapa preliminar. En este modelo están comprendidos los casos de Argentina (tanto a nivel federal - con el CPPN no implementado - como en la provincia de Neuquén), Chile, Ecuador, México, Panamá y Uruguay. En todos estos países se han estipulado audiencias para el control de la legalidad

(es decir, determinar el supuesto fáctico de la acusación). Y, por otro lado, en la audiencia preparatoria de juicio oral (regulada en el artículo 279 del CPP), que se celebra a petición de parte dentro de los cinco días anteriores a la realización del juicio, con el objetivo de discutir sobre la exclusión y acuerdos de prueba.

20 El Código Procesal Penal de Paraguay regula audiencias para la discusión de medidas cautelares, salidas alternas y acusación. Sin embargo, en el informe local se manifiesta que "las audiencias orales propiamente se realizan únicamente en la etapa de juicio. En la preparatoria e intermedia no se implementan".

21 Sin perjuicio de que en Perú no está regulada una audiencia de control de detención, el informe local consigna que a partir de diciembre del 2016 "se ha abierto paso a una suerte de regulación primigenia de esta forma de control, toda vez que se ha concretizado una audiencia donde se va a controlar la legalidad de la detención. Sin embargo, dicho plenario solo operará en un supuesto específico, esto es, en los casos donde exista flagrancia y el fiscal requiera al juez de la Investigación Preparatoria dentro de las doce horas de producida la detención efectiva por la Policía Nacional, la emisión de un mandato de detención judicial hasta por un máximo de siete días, cuando por las circunstancias del caso se desprenda cierta posibilidad de fuga u obstaculización de la averiguación de la verdad, siendo que antes de las 24 horas el juez realizará la audiencia (para) pronunciarse (...) en cuanto a la legalidad de la detención del imputado, sobre el cumplimiento de los derechos al momento de la detención y finalmente sobre la necesidad de dictar la detención judicial".

22 En el informe local se indica que "no existe una audiencia de control de detención. Tal control se lleva a cabo en la audiencia de medidas de coerción si el Ministerio Público decide solicitarla. En la práctica, por lo general, si un imputado es arrestado, el Ministerio Público solicita la medida de coerción. En este caso, sí se contempla un plazo de 48 horas, que también está consagrado en la Constitución, para presentar al imputado ante el juez, sino el Ministerio Público dispone su libertad inmediata." 
de la detención, formulación de la imputación, discusión de medidas cautelares, salidas alternativas y juicio abreviado, y control de la acusación. Es decir, que ante cualquier planteo de las partes se prevé que estos se diriman en el marco de una audiencia.

Un segundo modelo está dado por el proceso adversarial burocratizado, cuyo rasgo distintivo es la supervivencia de elementos característicos de los procesos mixtos o inquisitivos. Si bien algunos códigos, como el de El Salvador, estipulan la realización de audiencias en las fases tempranas del proceso, responden a la lógica del sistema tradicional en tanto mantienen instituciones como la declaración indagatoria como acto procesal inicial o incluso mantienen ese instituto pero solamente en sede fiscal y sin la necesidad de realizar una audiencia para formalizar la imputación, como Costa Rica. La mantención de la lógica tradicional también puede observarse en la regulación de la etapa intermedia. En Guatemala, esta fase se desdobla en dos audiencias fijando la primera para el debate sobre la admisión del caso a juicio y la segunda para la discusión sobre los medios de prueba que las partes pretenden presentar para acreditar sus posiciones. En Honduras, la admisión del caso se da en la audiencia preliminar y la discusión probatoria en la instancia de juicio oral. En esta estructura subyace una visión muy débil sobre la fase intermedia en tanto la litigación sobre la prueba se encuentra fuertemente limitada al producirse de forma posterior a la decisión sobre el sobreseimiento o la apertura a juicio. En cambio, en un sistema adversarial clásico, todas las discusiones sobre la admisibilidad debiesen darse en el marco de una sola audiencia y bajo la comprensión que el debate probatorio es dirimente para sopesar la viabilidad o éxito del caso.

El tercer y último modelo lo constituye el denominado proceso adversarial escriturizado. Es aquél en el cual la mayoría de las decisiones judiciales de la etapa preliminar se adoptan de manera escrita (como en Brasil, Cuba o Costa Rica) o en el que las audiencias se han convertido en representaciones distorsionadas de la oralidad. Una muestra de ello está dada por los casos de Brasil, en donde la audiencia de control de detención (de custodia) gira alrededor de un escrito (auto de prisión en flagrante) que le presenta la policía al juez o Venezuela, en donde el informe local manifiesta que "la realización de audiencias ha pasado a ser la excepción, incluso en la fase de juicio. Es usual la conversación informal el día señalado entre jueces, fiscales y defensores sobre los casos para luego hacer pasar al imputado y/o acusado a firmar las actas. La muestra más evidente la constituye las sentencias condenatorias provenientes en más de un 75\% de admisiones de hecho". 


\section{2.b Calidad del litigio en las audiencias}

En esta sección haremos un análisis acerca de los principales problemas y fortalezas en la dinámica de las audiencias orales que funcionan actualmente en los procesos penales latinoamericanos.

\section{Audiencias de control de detención}

En las audiencias de control de detención se observan dos problemas centrales. Por un lado, un rol muy pasivo del juez en el análisis de las condiciones en las que el imputado fue detenido. Por ejemplo, en Bolivia se informa que "el/la juez/a de instrucción no realiza un control de la duración de la aprehensión de oficio, sino siempre a solicitud de la defensa" y en la provincia argentina de Neuquén se alude que "el/la juez/a no controla de oficio si hubo apremios ilegales en contra del imputado, ni revisa si se le informaron sus derechos". El informe nacional de Chile consignó que "la cifra de detenciones declaradas como ilegales es sostenidamente baja a lo largo de los años, pues en el período observado (2006-2015) estas no superan en ninguno de los años al 1\% del total de audiencias". En cuanto al rol del/de la juez/a, "solo en un $20 \%$ de los casos observados tiene un rol activo en verificar las circunstancias de la detención; el juez pregunta al imputado si conoce y comprende los motivos de su detención en el 53\% de los casos; y en un 31\% de los casos pregunta al imputado por el trato recibido". Un segundo problema está dado por la primacía del expediente escrito o la ausencia de una instancia específica para controlar la detención, como en Brasil, en donde el/la juez/a recibe un escrito de la fiscalía y la discusión de la audiencia gira en torno a éste o en Costa Rica, en donde "el primer contacto que tiene una persona investigada o un imputado con un juez es en la audiencia de medidas cautelares". También se advierten inconvenientes en el cómputo de los plazos, como en Honduras, en donde "suele suceder que el término de la detención se comienza a contar a partir de la hora en que consta la lectura de derechos. Esta situación debe superarse a partir de las disposiciones de la Corte Suprema de Justicia (...) donde establece que la privación de libertad se contabiliza desde el momento en que al imputado se le priva de la misma".

\section{Audiencias de formalización de la investigación}

La audiencia de formalización de la investigación se encuentra regulada en diez sistemas procesales del total de los veintidós analizados y en el plano práctico se advierten dos tipos de problemas. Por un lado, una litigación formal por parte de los intervinientes, representada principalmente en la lectura de escritos o la descripción de los hechos desde la lógica del parte policial. En Chile, "las partes suelen intervenir de manera mecá- 
nica, pues el/la fiscal/a se limita a leer la formalización en la audiencia, sin generar un discurso pues se hace uso de un texto escrito que lee. Esta percepción es confirmada con datos sobre la duración de las audiencias. La audiencia de formalización se redujo de 10 minutos en promedio en el año 2006 a un promedio de 7,9 en el año 2015". En Guatemala, "la formulación de la imputación por parte del fiscal se realiza sin concentrarse en los hechos más importantes (la existencia del delito y probabilidad de participación del sindicado). Cometen la falencia de desarrollar relatos extensos y discuten (incluidos los defensores) las actuaciones del expediente de investigación, por lo que en algunas audiencias persiste la lectura de documentos". En Ecuador se afirmó que hay una "tendencia a que el discurso parta del parte policial". Por otro lado, existe una confusión entre la discusión de los hechos en el marco de la formulación de imputación y en el de la materialidad para las medidas cautelares. Por ejemplo, el informe de Panamá indica que no hay consenso en cuanto a la posibilidad de que, en esta instancia, la defensa debata y argumente sobre el fondo de la imputación. De hecho, desde el plano legal también se han generado este tipo de confusiones. Mientras que en Chile se trata de una facultad autónoma de la fiscalía, en otros países como Uruguay se regula que los jueces y juezas deben resolver si la admiten.

\section{Audiencias de medidas cautelares}

Las audiencias de medidas cautelares tienen aún un conjunto de problemas irresueltos que han sido objeto de discusión en las últimas décadas. El primero está dado por la ausencia de una estructura que defina los momentos para los distintos debates que se dan en ella. Esto se relaciona con un déficit legal, como en Bolivia, en donde el informe local consigna que "el Código Procesal Penal no define la estructura de la audiencia, pues solo establece los requisitos para la imposición de medidas cautelares". Por su lado, en Cuba, "en 1977 se suprimió la audiencia verbal para la imposición de medidas cautelares y se le entregó esta facultad al fiscal (mientras que) en 1994 se eliminó la intervención de los tribunales en esta decisión" es decir que actualmente se realiza por escrito.

Una segunda área se relaciona con un déficit en la calidad de información con la cual se litiga en esta audiencia. De este aspecto dieron cuenta una gran cantidad de informes nacionales. En Bolivia se produce una discusión muy débil del supuesto material en tanto "la exposición del/la fiscal no logra constituir un relato que describa de forma clara el hecho, la calificación legal que le corresponde y la participación que el imputado tuvo en el mismo". En cuanto al presupuesto procesal, agrega que "en gran parte de los casos, el/ la fiscal no ofrece $u$ ofrece muy poca evidencia para fundamentar los riesgos procesales que alega, con lo cual se invierte la carga de la prueba y son los imputados, a través de sus 
abogados, los que tienen que aportar evidencia sobre su arraigo social, familiar o laboral". Además, se informa que los elementos principales que se utilizan para configurar los riesgos procesales dicen relación con la gravedad del delito y la ausencia o existencia de antecedentes policiales o judiciales. De hecho, se señala que "respecto a la evidencia utilizada para definir el arraigo laboral, se observa que tanto jueces como fiscales exigen a la defensa la presentación de documentos que son muy difíciles de conseguir, tales como contratos registrados por una instancia pública (Ministerio de Trabajo)". Un problema adicional en Bolivia está dado por el hecho de que "en un importante porcentaje de casos los/as fiscales no participan en las audiencias, limitándose a enviar el cuaderno de investigaciones y la solicitud de imposición de una medida cautelar". En Chile "la calidad de la información es precaria (...) pues la argumentación de la fiscalía suele limitarse a la lectura del parte policial". Además, "se advierte que no existe un orden rígido en el debate, en el sentido de mantener la ritualidad de comenzar con el supuesto material y luego el procesal". Por otro lado, "el defensor en general no proporciona datos ni presenta una teoría propia, pues se limita a desvirtuar los argumentos de la Fiscalía. El fiscal no argumenta sobre la existencia del hecho en un 40\% de los casos observados; no lo hace sobre la participación del imputado en el hecho en un 50\% de los casos y en un $45 \%$ tampoco lo hace en relación a la necesidad de cautela". En Nicaragua, "para efectos de la imposición de medidas cautelares, la fiscalía sustenta su solicitud de los riesgos procesales sobre la base de la acusación, peligro de evasión, gravedad o magnitud de los hechos, la posible pena a imponer y la naturaleza del delito". Además "existen delitos que por imperio de Ley deben ser tramitados bajo la medida cautelar de prisión preventiva". En Ecuador hay problemas en la justificación del peligro procesal. La fiscalía "se limita a indicar que la defensa no ha justificado vínculos con la colectividad. Explicación ilegítima en razón de que la Fiscalía es quien tiene la carga de la prueba". En la provincia argentina de Neuquén, "a los fines de discutir los riesgos procesales, principalmente los vinculados con la falta de arraigo, las fiscalías suelen contar con poca información sobre la situación personal del/a imputado/a y no cuentan con un servicio dentro del Ministerio Público Fiscal que se encargue de esta búsqueda". Es decir que podemos concluir que aún se trata de una audiencia que gira alrededor de los elementos tradicionales vinculados a la imputación (tipo de delito y pena en expectativa) y no se ha logrado torcer el debate hacia elementos concretos relativos a la situación personal del imputado.

Un tercer y último problema se vincula con la ausencia de fijación de plazos y mecanismos de supervisión de las medidas cautelares. En Bolivia se consignó que esto no ocurre en la mayoría de las audiencias mientras que Chile carece de una institución dedicada a dar seguimiento al cumplimiento de las medidas cautelares y "el comportamiento habi- 
tual de los defensores es no solicitar al juez la fijación de un plazo judicial en consideración de los antecedentes concretos de la causa. Y, en los casos en que se produce el debate, este es promovido en su mayoría de oficio por el juez (52\%) versus un $32 \%$ de los casos en que se promueve por la defensa". En el estado mexicano de Nuevo León se informó que "en 5 de 6 casos, el/la juez/a impuso medidas cautelares sin especificar su duración; solo se limitó a expresar que aquellas tendrían vigencia 'durante el procedimiento'”. Sin perjuicio de ello se han dado experiencias interesantes en relación a estos dos últimos problemas. En Nicaragua, "El Código Procesal Penal contiene las normativas pertinentes para dar el adecuado seguimiento y control a las medidas cautelares impuestas a toda persona sometida a proceso penal. En el país se han creado oficinas de apoyo a la labor judicial que permiten obtener información fidedigna sobre el cumplimiento de las medidas cautelares, por ejemplo, la Oficina de Control de Procesados, donde diariamente se recibe a las y los acusados, quienes llegan a firmar una ficha de control de presentación periódica, según la frecuencia señalada por el juez en la resolución". En Panamá, "una práctica a destacar es que en la provincia de Colón los fiscales desde la Sección de Atención Primaria en la cual se prepara la carpeta para las labores de litigación que posteriormente realizará la Sección de Decisión y Litigación Temprana envían comisión a la Dirección de Investigación Judicial para que se verifique si el imputado tiene residencia fija o no, si labora, si tiene familia, vínculos con la comunidad (todos los temas de arraigo), cuál es su historia médica, entre otros. Esta información la utilizan para seleccionar de inicio la medida cautelar que estiman idónea”.

\section{Audiencias de salidas alternativas}

En relación a las audiencias de salidas alternativas (suspensión condicional del proceso y acuerdos reparatorios) se observa un tema central: no existe una tendencia marcada en la región en cuanto a la necesidad de que el juez asuma un rol activo en la solución del conflicto primario. Por ejemplo, en Costa Rica se señaló que "los jueces penales no hacen un gran esfuerzo como en otras materias para lograr soluciones alternativas al juicio. Su rol se puede resumir en un agente de control de legalidad y cumplimiento de los requisitos" y en Honduras que "el juez únicamente confirma que los requisitos formales concurran para autorizar la salida alterna. En relación con los términos del acuerdo, el juez no ejerce mayor control, sólo verifica que el imputado conozca los alcances de la medida alterna y que esté de acuerdo con los términos de la reparación del daño". Sin embargo, cabe mencionar los casos de la provincia argentina de Neuquén, en donde como buena práctica se resalta que "el/la juez/a siempre controla que el imputado preste su conformidad y le explica la finalidad y los efectos del beneficio, así como las consecuencias que acarrea no 
cumplir con las reglas de conducta establecidas" y Chile, en donde en las audiencias de suspensión condicional del proceso "en un $80 \%$ de los casos el juez pregunta al imputado si entiende las condiciones que le son impuestas; y, por otro lado, en el 67\% de los casos el juez señala expresamente al imputado que al aceptar la suspensión condicional está renunciando a su derecho al juicio oral. En cuanto a los acuerdos reparatorios, el juez explica sus consecuencias al imputado en un $72 \%$ de los casos y en un $63 \%$ de las ocasiones le pregunta si entiende el contenido y alcances del acuerdo. Por otro lado, en un $80 \%$ de los casos, el juez le da la palabra a la víctima antes de que acepte el acuerdo; y en un $77 \%$ lo toma en consideración al momento de aprobarlo. En estos casos, "el tipo de contraprestación más usual es el pago de una suma de dinero representando un $58 \%$ y disculpas públicas en un $23 \%$ ".

\section{Audiencia de etapa intermedia}

La audiencia de etapa intermedia no se ha consolidado como una instancia central en la generación de acuerdos o depuración de la prueba de manera preparatoria al juicio oral. Esta afirmación se apoya principalmente en la baja intensidad en la exclusión probatoria durante esta audiencia.

En Chile, "existe cierto temor en dejar fuera cierta prueba del juicio oral. (...) El rol del defensor tampoco parece ser muy activo, ya que la defensa solicita la exclusión de alguno de los medios de prueba ofrecidos por el fiscal en el 35\% de los casos; y la defensa ofrece prueba propia en solo un $40 \%$ de los casos". En cuanto a los tiempos de duración de esta audiencia, cabe resaltar que "en el año 2006 duraba en promedio 37,5 minutos, mientras que en el año 2014 esa cifra se redujo a 16,4 minutos en promedio". En El Salvador, "no todos los jueces de instrucción discuten la pertinencia de la prueba. Si la defensa no se opone a la introducción de prueba, el juez la admite". En Ecuador, "los debates son formales y superficiales en todos los temas. (...) En los acuerdos probatorios normalmente solo se hacen referencias formales, simplemente se menciona que no hay acuerdos y no existe un intento real de negociación". En República Dominicana, "el desconocimiento de las técnicas de litigación la afecta al nivel de profundidad con el que se llevan a cabo las discusiones, pero sobre todo el rol del juzgador cuando se vuelve demasiado pasivo debiendo resultar todo lo contrario". En Colombia, en "la audiencia preparatoria, en la que se han introducido numerosos pasos que la han hecho repetitiva y poco ágil, (...) existen confusiones entre los conceptos de pertinencia, conducencia y utilidad de las pruebas, que generan discursos reiterativos que no aportan en la acotación del debate probatorio". Esto tiene un impacto en la dinámica del juicio oral, en tanto "al no existir una adecuada depuración de las pruebas, pueden llevarse hasta decenas de testigos de los cuales solo unos 
resultan útiles para lo que se pretende demostrar. De otra parte, tampoco ha sido afortunada la forma en la que se introducen las pruebas al juicio, pues se confunden los testimonios con la lectura de informes y entrevistas que no permiten garantizar el principio de contradicción". En la provincia argentina de Neuquén, "si bien esta audiencia debería utilizarse como la última instancia para llegar a acuerdos entre las partes (de suspensión del proceso a prueba o de procedimiento abreviado), ya que la ley así lo establece, luego de esta audiencia si las partes llegan a salidas alternas, los jueces aceptan estos acuerdos". En Guatemala "en la audiencia intermedia, una de las quejas recurrentes de los jueces es que el fiscal desconoce el caso, por lo que es común la mala práctica de leer la acusación en la audiencia. Este problema es derivado del modelo de gestión de las fiscalías, en donde el fiscal que llevó a cabo la investigación no entrega el caso a tiempo al fiscal de litigios que participará en la audiencia intermedia. En la audiencia ofrecimiento de prueba, se han identificado dos debilidades: que los jueces no generan la discusión sobre los medios de prueba por parte de la fiscalía y la defensa; y que regularmente, los sujetos procesales describen a detalle el objeto de la declaración de testigos y peritos, lo cual constituye un antecedente negativo para el tribunal de sentencia, por lo que es común la afirmación "la prueba llega contaminada" al juicio". En el informe estadual de México se informa que "esta audiencia pierde relevancia dado que el debate se adelanta durante la audiencia inicial por la figura de vinculación a proceso. Existe una iniciativa de reforma para eliminar la vinculación a proceso de la audiencia inicial, lo que de proceder permitiría fortalecer la etapa intermedia".

En otros países se ha llegado a eliminar esta audiencia o analizar su exclusión. En Bolivia, esta audiencia estuvo sujeta a diversos cambios. Si bien el CPP aprobado en 1999 previó la realización de una audiencia preparatoria de juicio, lo cierto es que éstas no se realizaban con frecuencia. Esto llevó a que en el 2010 se introduzcan cambios al ordenamiento normativo para detallar la dinámica específica que dicha audiencia debía seguir. Sin perjuicio de ello, el informe nacional indica que "debido a los problemas administrativos que dificultaron sobre manera la instalación de dichas audiencias, en octubre de 2014, la ley de descongestionamiento y efectivización del sistema penal modificó nuevamente el CPP y obligó al juez instructor a remitir la acusación al juez o tribunal de sentencia en el plazo máximo de 24 horas". Es decir, que se eliminó la regulación de la audiencia de etapa intermedia y se reemplazó por una remisión directa por escrito. Por su lado, en Costa Rica, "desde la jerarquía del Poder Judicial han sido anunciados proyectos para proponer reformas legislativas que eliminen esta audiencia, de forma tal que los casos pasen directo desde la redacción de la acusación hacia el debate o juicio oral (...). Se dice en Costa Rica que la audiencia preliminar, lejos de ser una fase 
estratégica para el funcionamiento del sistema, se volvió en un mero trámite (...) Ello ha obligado a los jueces de juicio a tener que atender incidentes de exclusión de prueba ilícita, actividades procesales defectuosas y hasta casos que no debieron haber llegado a esa etapa".

\section{Audiencia de juicio oral}

Por último, si bien el juicio oral existe en la región hace décadas, lo cierto es que actualmente presenta dos problemas centrales. Por un lado, se advierte aún un rol activo del juez en la realización de preguntas a los testigos. En Bolivia, "el rol del/la juez/a durante la audiencia de juicio no es totalmente pasivo. Los operadores entrevistados coinciden en afirmar que regularmente los jueces formulan preguntas a los testigos, para aclarar las dudas que tienen". En Brasil, sin perjuicio de que en el 2008 se reformó el texto del ordenamiento procesal para incorporar la técnica del examen y contra examen de la prueba, en la actualidad los jueces y juezas tienen un rol muy activo en la realización de preguntas a los/as testigos, lo cual en varios casos supera la profundidad con la cual los interrogan los y las litigantes. En Cuba, a partir de una guía metodológica para la realización de juicios orales emitida por el Tribunal Supremo Popular, se intentaron corregir ciertos vicios en la dinámica del juicio oral. En la actualidad, tal como afirma el informe local, "al comienzo del juicio el secretario da lectura a un resumen de los hechos que son objeto de la acusación, que ha sido previamente elaborado por el juez ponente de la causa, de tal suerte que si las partes prescinden de la lectura de sus escritos de calificación, como sigue ocurriendo en la actualidad, los presentes tengan al menos una referencia del contenido de la acusación". Una vez realizado el interrogatorio de testigos y peritos, los tribunales tienen libertad para el interrogatorio, facultad que por lo general ejercen, para lograr la mayor certeza sobre el controvertido. Tienen también la posibilidad de incorporar determinados medios probatorios, consistente en todos aquellos que consideren necesarios para la comprobación de cualquiera de los hechos que hayan sido objeto de los escritos de las partes, cuando no han sido suficientemente esclarecidos, a criterio del juzgador".

Por otro lado, se observa una baja calidad en la litigación durante la audiencia de juicio. Esto se desprende de la realidad de un conjunto de países. En Chile, "existe la percepción de que los interrogatorios son meros ejercicios retóricos, más bien mecánicos y que los contrainterrogatorios son inconsistentes. (...) Un dato que resulta importante destacar es el aumento en las sentencias absolutorias. En el año 2006, el porcentaje de sentencias condenatorias alcanzó el 81\% del total, mientras que en el año 2015 alcanzó el $65,3 \%$ de las sentencias de tribunales de juicio oral". En Ecuador, "el contra examen (...) 
se hace de manera ineficaz; la falta de técnica para sacar a relucir debilidades hace que lo más común es que sea una extensión del interrogatorio. Las objeciones son inutilizadas". En Costa Rica, "no se permite a las partes, por ejemplo, hacer un alegato inicial. Cuando en algunos lugares se inició esa práctica, magistrados de la jerarquía en sus giras por el país decían que esa práctica era ilegal, porque en Costa Rica la norma dice que el fiscal debe leer la acusación. Ello motivó a que se abandonara esa práctica. De modo que un tribunal de juicio inicia un debate habiendo escuchado solamente la lectura de la acusación, sin dar a la defensa la posibilidad de proponer una visión distinta al tribunal". En Honduras, "la prueba testifical sigue siendo una de las más propuestas por las partes, por lo cual resulta preciso resaltar la necesidad de mejorar las técnicas de interrogatorio y contrainterrogatorio; sobre todo frente a la regulación procesal del país que prohíbe la formulación de preguntas capciosas o sugestivas en los mismos. (...) Esta necesidad de reforzar la técnica de interrogatorio y contra interrogatorio de las partes, se refleja precisamente en que para superar los vacíos de información (debido a la falta de una técnica adecuada), los tribunales intervienen activamente formulando preguntas que consideren oportunas y que no se han realizado por las partes o se han realizado de forma incorrecta". Sin embargo, cabe resaltar la experiencia de la provincia argentina de Neuquén, en donde "por regla general, se advierte que las partes durante las audiencias de juicio tienen una estrategia sobre el caso" y que "durante toda la audiencia, el/ la juez/a asume un rol pasivo y nunca introducen preguntas". La implementación del juicio por jurados ha aumentado la calidad del litigio y permitido que el lenguaje de los litigantes se simplifique.

\section{2.c. La regulación del juicio por jurados}

En el apartado anterior nos referimos a las problemáticas que se presentan alrededor de los juicios orales en la región. En esta sección nos focalizaremos en una de las modalidades posibles para la sustanciación del juicio: mediante un tribunal integrado por jurados populares. En nuestra opinión, esta dinámica constituye uno de los mecanismos más eficaces para ampliar la participación de la ciudadanía en la justicia penal y democratizar el funcionamiento de los sistemas judiciales.

En la siguiente tabla se presenta información relativa al modo en que se encuentra regulado el juicio por jurados en los ordenamientos procesales penales de la región, en particular, en cuanto al tipo de delitos en los que intervienen y la cantidad de integrantes que forman parte del jurado. 
Tabla 3. Situación del juicio por jurados en América Latina

\begin{tabular}{|c|c|c|c|}
\hline PAís & $\begin{array}{l}\text { FUNCIONAMIENTO } \\
\text { DE JUICIO POR } \\
\text { JURADOS }\end{array}$ & TIPOS DE DELITOS EN LOS QUE INTERVIENE & $\begin{array}{l}\text { CANTIDAD DE } \\
\text { INTEGRANTES DEL } \\
\text { JURADO }^{23}\end{array}$ \\
\hline Argentina (Federal) & $\mathrm{No}^{24}$ & - & - \\
\hline Argentina (Neuquén) & Si & $\begin{array}{l}\text { Casos con pena superior a los } 15 \text { años y delitos } \\
\text { contra la integridad sexual o que tengan como } \\
\text { resultado la muerte o lesiones gravísimas }\end{array}$ & 12 \\
\hline Bolivia & No & - & - \\
\hline Brasil (Federal) & $\mathrm{Si}$ & Delitos dolosos contra la vida & 7 \\
\hline \multicolumn{4}{|l|}{ Brasil (Bahía) } \\
\hline Chile & No & - & - \\
\hline Colombia & No & - & - \\
\hline Costa Rica & No & - & - \\
\hline Cuba & $\mathrm{Si}$ & Todos $^{25}$ & 2 \\
\hline Ecuador & No & - & - \\
\hline El Salvador & $\mathrm{Si}$ & $\begin{array}{l}\text { Lesiones, lesiones graves y muy graves, lesiones } \\
\text { agravadas, relativos a la autonomía personal y } \\
\text { daños y daños agravados }\end{array}$ & 5 \\
\hline Guatemala & No & - & - \\
\hline Honduras & No & - & - \\
\hline México (Federal) & No & - & - \\
\hline México (Nuevo León) & No & - & - \\
\hline Nicaragua & $\mathrm{Si}$ & $\begin{array}{l}\text { Lesiones graves, lesiones gravísimas y hurto } \\
\text { agravado. }\end{array}$ & 6 \\
\hline
\end{tabular}

23 En esta columna se consigna el número de jurados titulares que intervienen en el juicio.

$24 \mathrm{El}$ artículo 249 del nuevo CPP prevé la integración de un tribunal por jurados cuyas definiciones específicas quedan delegadas a una ley especial: "La ley de juicio por jurados determinará la composición, integración, constitución, sustanciación y deliberación del juicio en el que participe un tribunal de jurados".

25 En Cuba, el autor local informa que "la proporción en cuanto a la integración de los tribunales depende del nivel jurisdiccional y de otras condiciones de organización. Los casos de menor complejidad que se conocen en los municipios, de sanciones hasta un año de privación de libertad, el tribunal se integra por un juez profesional y dos jueces legos. En el nivel provincial y en el Supremo para un grupo considerable de casos, el tribunal se integra por cinco jueces, de los cuales 3 son profesionales y dos legos. Pero hay casos en que el tribunal puede estar integrado por 3 jueces". Cabe precisar que en Cuba "se utiliza la categoría de "jurado" para identificar a los ciudadanos miembros del jurado de corte anglosajón, que emiten un juicio binario sobre culpabilidad, mientras que los ciudadanos que integran el tribunal escabinado tienen la categoría de jueces, en igualdad de condiciones que los jueces profesionales". 


\begin{tabular}{|c|c|c|c|}
\hline PAís & $\begin{array}{l}\text { FUNCIONAMIENTO } \\
\text { DE JUICIO POR } \\
\text { JURADOS }\end{array}$ & TIPOS DE DELITOS EN LOS QUE INTERVIENE & $\begin{array}{l}\text { CANTIDAD DE } \\
\text { INTEGRANTES DEL } \\
\text { JURADO }^{23}\end{array}$ \\
\hline Panamá & $\mathrm{Si}$ & $\begin{array}{l}\text { 1. Homicidio doloso que no sea producto de } \\
\text { delitos de terrorismo, secuestro, extorsión, } \\
\text { asociación ilícita, pandillerismo, narcotráfico o } \\
\text { blanqueo de capitales. } \\
\text { 2. Aborto provocado por medios dolosos, } \\
\text { cuando, por consecuencia de este o de los } \\
\text { medios usados para provocarlo, sobreviene la } \\
\text { muerte de la mujer. } \\
\text { 3. Que impliquen un peligro común y los delitos } \\
\text { contra la salud pública cuando, por consecuencia } \\
\text { de ellos, sobreviene la muerte de alguien, con } \\
\text { excepción de los causados por imprudencia, } \\
\text { negligencia o impericia en el ejercicio de una } \\
\text { profesión u oficio. }\end{array}$ & 7 \\
\hline Paraguay & No & - & - \\
\hline Perú & No & - & - \\
\hline $\begin{array}{l}\text { República } \\
\text { Dominicana }\end{array}$ & No & - & - \\
\hline Uruguay & No & - & - \\
\hline Venezuela & No & - & - \\
\hline
\end{tabular}

Fuente: Elaboración propia

El juzgamiento por jurados populares en el proceso penal ha estado en el centro del diseño de la justicia criminal en casi todas las constituciones políticas latinoamericanas desde comienzos del siglo XIX. En muchas de ellas aún continúa regulado pero no se ha vuelto una realidad, como los casos de Argentina (cuya última reforma constitucional, en 1994, ratificó los tres artículos en los que el instituto está previsto), Colombia (los jurados de conciencia están regulados a nivel constitucional mediante el artículo 116 que dispone "los particulares pueden ser investidos transitoriamente de la función de administrar justicia en la condición de jurados en las causas criminales, conciliadores o en la de árbitros habilitados por las partes para proferir fallos en derecho o en equidad, en los términos que determine la ley") y Uruguay. En Chile funcionó, de manera interrumpida, el juicio por jurados para los juicios de imprenta entre 1813 y 1925. Mediante un breve reglamento sobre libertad de imprenta, se estipuló al jurado como una protección de la libertad de prensa en la época. En México se encuentra expresamente regulado en el artículo 20 de su Constitución del año 1917 como una garantía en los juicios penales. En otros países se ha eliminado, como en Venezuela (el modelo clásico se eliminó en el 2001 y en el 2012 el de escabinos) y Bolivia, en donde el informe local reporta que "el CPP aprobado en 1999 preveía la realización de juicios orales con jueces ciudadanos en el marco del tribunal escabino (dos jueces técnicos 
y tres ciudadanos) para los delitos de acción pública, sancionados con pena privativa de libertad cuyo máximo legal sea mayor a cuatro años. Luego de algunos años, se evidenciaron problemas de gestión que afectaron los procesos de constitución de los tribunales de sentencia, lo cual provocó una elevada congestión judicial que perjudicó sobremanera el inicio y la prosecución de las audiencias de juicio. Por estas razones, en octubre de 2014, la Ley de descongestionamiento y Efectivización del sistema procesal penal suprimió la institución de los jueces ciudadanos". En Nicaragua, frente a la dificultad que se presentó en los últimos años en la convocatoria de jurados ciudadanos, el informe describe que "se ha emprendido una labor de publicidad sobre la responsabilidad ciudadana de impartir justicia, iniciando un programa radial desde hace siete años - denominado una hora con la Justicia, éste se transmite una vez por semana, a este acuden Jueces, abogados litigantes y facilitadores judiciales".

\section{Propuestas para el fortalecimiento de la oralidad y el litigio}

Sin lugar a dudas, la oralidad ha sido uno de los elementos protagónicos en los procesos de reforma a la justicia penal en América Latina. Para iniciar este apartado se podrían mencionar decenas de consideraciones, interpretaciones y análisis que han surgido en base a este emblemático principio de los nuevos sistemas adversariales. Para salirnos de las referencias más conocidas por el público optaremos por iniciar el análisis haciendo mención a una de las cualidades de la oralidad que no siempre ha sido tan destacada. Nos referimos a la vinculación entre oralidad y la idea del juicio.

Dice Binder (2014, p.29) que "cuando se habla de "oralidad" en realidad lo que se quiere transmitir es que todo ciudadano tiene derecho a que no se imponga una pena sin un juicio previo, y juicio no es cualquier trámite sino la estructura (conjunto de formas vinculadas a los actos, sujetos, tiempo, espacio, coerción y caso) que sostiene la imparcialidad, la contradicción y la publicidad". En consecuencia, la idea de juicio como "elemento central del proceso" no sólo se ha invisibilizado en los sistemas de enjuiciamiento inquisitivo sino también en los recientes sistemas adversariales. Por lo tanto, "cuando hablamos de oralidad como uno de los valores de la reforma procesal penal nos referimos a este ideal de juicio previo, en el que se despliegan una serie de herramientas o principios colaterales como la inmediación, publicidad, contradicción y la concentración".

Como extraemos de la reflexión de Binder, la oralidad condensa un ideal de justicia que tiene como contraposición más evidente el trámite inquisitivo en donde la idea de juicio se difumina entre mecánicas actuaciones de carácter secreto y escrito. Esta vinculación de oralidad con la institución del juicio detrás de la cual subyacen un conjunto de efectos 
(como los mencionados) es la cristalización de la concepción de la oralidad como un principio político de las reformas al proceso penal. La finalidad de este objetivo político es desterrar el modelo de juzgamiento inquisitivo caracterizado por la escrituración como forma de juzgamiento de la cual nuevamente se desprenden otras consecuencias como la delegación de funciones jurisdiccionales, la opacidad de las actuaciones judiciales y la íntima convicción del juzgador como criterio valorativo.

Siguiendo nuevamente a Binder (2012), la otra gran dimensión de la oralidad es que nos da la posibilidad de situar a la audiencia como el espacio ideal para que se produzca la pacificación del conflicto. A diferencia del trámite inquisitivo, en donde la participación del imputado y la víctima era marginal, en el sistema adversarial se produce una escenificación del conflicto en la audiencia oral lo que permite que se exteriorice el conflicto y se produzca un debate y deliberación entre los diversos actores allí representados. En esta pacificación del conflicto se destaca la importancia de la ritualidad bien entendida en el sentido de que esa escenificación transmita un mensaje que impacte en los destinatarios en el nivel social.

Como veremos más adelante, uno de los aspectos que es necesario revitalizar en la justicia penal contemporánea es el ideal restaurador y de reparación a través de las vías composicionales de solución de conflictos. La oralidad será la única herramienta que nos permita obtener resultados positivos en este importante desafío.

A continuación, realizaremos un breve análisis de qué aspectos de la oralidad no están teniendo el desarrollo deseado en el funcionamiento actual de los sistemas de justicia penal.

\section{El rescate de la garantía del hecho}

Hemos observado que en muchos de los nuevos sistemas de justicia penal latinoamericanos, la audiencia de formalización de la investigación se ha convertido en una instancia bastante formal en la cual la fiscalía comunica al imputado/a en presencia de su defensor/a y el/la juez/a cuáles son los hechos por los que será investigado. Este momento se convierte en un hito procesal ya que desencadena el cómputo de algunos plazos como, por ejemplo, la duración de la etapa de investigación criminal. Además, en muchos casos esta audiencia se fusiona con otras como la solicitud de alguna medida cautelar sobre el/la imputado/a o la solicitud de alguna salida alternativa al juicio oral.

Se ha comprobado que en varios países existe poca calidad en la información del hecho a formalizar. Esto puede ser debido a dos factores. En primer lugar, ocurre que en el relato de la fiscalía suele existir bastante preeminencia de la información proveniente del parte policial. Esto es problemático ya que supone que la descripción de hechos realizada por el/ la fiscal/a puede estar sesgada y por lo tanto va a afectar con posterioridad todo el trabajo realizado en el proceso penal. En segundo lugar, los hechos descritos en la formalización 
no siempre tienen el nivel de claridad y detalle necesario. Solemos hablar de la necesidad de que los hechos contenidos en la formalización sean autosuficientes y al menos sean capaces de contestar a las siguientes preguntas:¿Quién?¿Cuándo? ¿Dónde? ¿Qué? Y ¿Cómo?

La audiencia, por lo tanto, debe ser el espacio idóneo para poder mejorar y rectificar esta información proveniente de la fiscalía cuando no reúna el estándar adecuado para la formalización de los hechos a investigar. El rol de la defensa será crucial para poder advertir la necesidad de que los hechos se puedan detallar, profundizar o rectificar. La importancia estratégica de la labor de la defensa en esta audiencia viene determinada por el principio de congruencia que limitará la acusación fiscal a los hechos que inicialmente fueron formalizados. El/la juez/a de garantía, por su parte, deberá intervenir en el debate y corroborar si el detalle de los hechos se ha realizado de forma adecuada incluso cuando la defensa no haya controvertido la información (Rua y González, 2018).

Si la audiencia de formalización se convierte en un ritual para comunicar una información al/a la investigado/a, sin ningún tipo de posibilidad de intervención o de modificación en la descripción del hecho, pierde sentido en su papel de favorecer un mejor intercambio de información.

La formalización de la investigación es concebida como un derecho del/de la imputado/a a la que Binder se ha referido como garantía del hecho. Desde esa perspectiva, será necesario advertir del problema que en muchos casos esta formalización venga acompañada de forma inmediata de una solicitud de salida alternativa o de medida cautelar. En estos casos, es posible que el derecho a conocer de forma anticipada cuáles son los hechos sobre los que se está siendo investigado requiera que tengamos un tiempo razonable para asimilar los hechos y analizar estrategias de defensa antes de ser requerido por el Ministerio Público a participar en nuevas actuaciones procesales.

En el último tiempo, en algunos países como Chile, se han planteado algunos debates como la hipótesis de que la formalización de una investigación supone un perjuicio importante para el/la imputado/a, suponiendo una afectación del principio de presunción de inocencia por la realización de juicios paralelos por la opinión pública (Ried, 2017). En ese sentido, es importante recordar que existen varias situaciones procesales en las que las audiencias orales y públicas se realizan con la participación de un/a imputado/a en calidad de presunto inocente sobre el cuál se realizan una serie de acusaciones, en algunos casos solicitudes muy graves como la privación preventiva de libertad a la espera de juicio. Todas estas actuaciones, se realizan de forma pública con la finalidad de que la comunidad en su conjunto pueda tener conocimiento de cómo se resuelven y pacifican los conflictos ante la justicia estatal. Por lo tanto, sin perjuicio de que pueda existir el riesgo de que la imagen o el prestigio del/de la imputado/a se debiliten por estos comportamientos indebidos de 
los medios de comunicación pensamos que esto no justifica la supresión de la publicidad en esta etapa procesal. Por el contrario, deben reivindicarse otras vías que no atenten contra las audiencias públicas y que no supongan volver a concepciones opacas y secretas de la investigación criminal. Pareciese mucho más prudente realizar un trabajo persuasivo y colaborativo de educación a los medios de comunicación acerca de cuáles son las características del sistema de justicia penal que no siempre se ha realizado.

\section{Las audiencias de acuerdos}

La mayoría de países de la región regula audiencias orales para la formalización de acuerdos entre las partes, ya sean suspensiones condicionales del procedimiento o acuerdos reparatorios. El fundamento de estas audiencias suele estar centrado en que el/la juez/a acredita la concurrencia de los requisitos procesales necesarios para la procedencia de estos acuerdos.

Hemos observado que en la mayoría de casos las negociaciones se han producido fuera de la audiencia entre las partes, ya sea entre la fiscalía y el/la defensor/a o directamente entre la víctima y el/la imputado/a, como suele requerirse para el caso de los acuerdos reparatorios. Por lo tanto, como los acuerdos suelen estar conversados de forma previa, las audiencias de acuerdos suelen tener poca duración y pocas veces se desvían de la verificación de los requisitos legales.

Para evitar esa lógica, las audiencias de acuerdos son un espacio privilegiado para discutir las causas reales del conflicto entre las partes y sobre todo, generar diversas alternativas que coadyuven a su solución. Es muy frecuente que a la hora de imponerse una condición al imputado estas suelen formularse de forma excesivamente general o no vinculada al conflicto original o a la resocialización del/de la imputado/a. Si insertamos en la audiencia de acuerdos la lógica de gestión del conflicto, podemos dirigir el debate de, por ejemplo, la suspensión condicional hacia la imposición de una condición que pueda ayudas a reducir el nivel de conflictividad entre las partes e, incluso, a insertarnos en un paradigma restaurador como veremos más adelante.

La labor judicial en las audiencias de acuerdos muchas veces ha quedado diluida por la errónea creencia de que el juez en un sistema adversarial debe ser pasivo y no entrometerse en la litigación de las partes. Por el contrario, el juez o la jueza en la etapa de investigación sí que tiene un rol mucho más activo no sólo en el sentido de exigirle información a las partes, sino también de poder promover que las partes exploren diversas opciones como una salida alternativa. Obviamente, no nos referimos aquí a un/a juez/a que apruebe acuerdos no autorizados por las partes, sino por el contrario un/a juez/a que da la posibilidad a las partes de que exploren y conversen sobre esas alternativas que la legislación procesal ofrece. 
Por otro lado, consideramos que el/la juez/a no debiese ingresar a analizar en cada caso concreto el mérito o la proporcionalidad del acuerdo, ya que la lógica del sistema adversarial confía en que cada una de las partes gestiona su caso en base a sus intereses y la fortaleza de su caso mientras que la autoridad judicial debe resguardar en todo momento su imparcialidad. Solamente en aquellos casos excesivamente desproporcionales o en los que pueda presumirse que existe sometimiento o abuso de una parte sobre la otra, la autoridad judicial debería intervenir (Rua y González, 2017).

\section{Oralidad y medidas cautelares}

En la actualidad, podemos comprobar que en muchos países de la región las audiencias de medidas cautelares no se realizan bajo un debate en profundidad acerca del supuesto material y procesal que fundamenta la posibilidad de imponer una medida cautelar.

Independientemente de que la prisión preventiva ha tenido un rebrote debido a la implementación de la prisión preventiva oficiosa en determinados delitos que ha sucedido en algunos países como México o la restricción de las medidas cautelares alternativas en casos de reincidentes y delitos contra la propiedad así como la aparición de riesgos procesales abstractos en las agendas cortas anti delincuencia de Chile (Fandiño et. al, 2018), es necesario destacar a la oralidad como herramienta para promover un debate de mayor calidad en base a la configuración de los requisitos para imponer una medida cautelar.

Todavía vemos como los y las fiscales solicitan medidas cautelares muy intensas como la prisión preventiva aludiendo a la gravedad del delito o al monto de pena en expectativa. Si bien esta forma de proceder no se corresponde con la forma adecuada de solicitar una medida cautelar, también es grave comprobar como la defensa no suele hacer una contra argumentación ante esta forma de proceder y que el juez no dirige el debate hacia la necesaria focalización del debate en la configuración de los supuestos material y procesal.

En una audiencia de medida cautelar, el/la juez/a de garantía, en su rol de interpelación a las partes para exigirles información como corresponde en la etapa de investigación, debe solicitar a la fiscalía que proceda a la explicación de qué los hechos alegados están tipificados y que existe alguno de los riesgos procesales que la legislación estipula.

Finalmente, otro desafío que debe fortalecerse es la instalación de Servicios de Antelación al Juicio (SAJ) u Oficinas de Medidas Alternativas y Sustitutivas (OMAS) para que un organismo de estas características pueda proveer información objetiva acerca de la situación económica, familiar y laboral del imputado para que el debate de medidas cautelares se produzca sobre la base de información de mayor calidad. 


\section{La oralidad en la etapa intermedia}

Uno de los elementos que garantiza el funcionamiento adecuado del proceso penal es la preservación de la audiencia de juicio oral como un espacio para pacificar sólo los conflictos más graves que el Ministerio Público decida elevar por criterios de política de persecución penal. Como dice Binder, (1993, pág. 231) "muchas de las grandes decisiones de política procesal que le dan carácter al proceso penal pasan por ésta fase intermedia y por el modo concreto como se controla el resultado de la instrucción". De esta forma, esta etapa procesal aparece como la última oportunidad antes del juicio para alcanzar acuerdos entre las partes, para controlar la acusación del fiscal o para preparar la audiencia del juicio oral.

Como se ha explicado (González, 2018) podríamos mencionar tres grandes objetivos asociados a la audiencia de etapa intermedia: A) Mejorar la eficiencia en el sistema de justicia a través de la posibilidad de alcanzar acuerdos entre las partes; b) Controlar la calidad de la información en el proceso y c) Realizar un debate relacionado con admisibilidad y exclusión probatoria.

Hemos analizado varias limitaciones en el funcionamiento de la oralidad en esta etapa procesal. En primer lugar, existen varios países en los cuales todavía no existe regulación específica de audiencias para este momento procesal como Bolivia o en donde los objetivos de esta etapa se encuentran diseminados en dos audiencias como en Guatemala y Honduras. Producto de lo anterior se percibe como en algunos países esta etapa todavía no es vista como un momento central del proceso.

Otro de los déficits en esta audiencia lo encontramos en la participación de los jueces y juezas y su capacidad para dirigir el debate fomentando el contradictorio entre las partes y una mayor calidad de la información. Debiese profundizarse en las técnicas de audiencia para poder generar debates de mayor calidad en esta etapa procesal. Por ejemplo, es frecuente todavía que los debates relacionados con admisibilidad y exclusión probatoria sean bastante formales y no se realice el trabajo de filtrar medios probatorios de baja calidad. En este sentido, creemos que se vuelve necesario rediscutir la teoría probatoria que subyace a la regulación de la etapa intermedia e identificar que el sistema adversarial nos interpela a la construcción de estándares de admisibilidad que sean filtros muy estrictos para la discusión probatoria. En concreto, se impone repensar el criterio de relevancia o pertinencia como aquél que constituye el eje central alrededor del cual debiesen producirse en primer lugar los debates sobre la admisibilidad de la prueba. De hecho, los sistemas adversariales de larga tradición como el canadiense los denomina como el "corazón del sistema de admisión".

Si profundizamos al respecto en los problemas de la prueba pericial, vemos como en países con más de una década de sistema adversarial como Chile todavía persisten pro- 
blemas como el bajo control de la idoneidad del perito, la existencia de un debate de muy baja calidad en torno a la admisibilidad o el poco respaldo de las Cortes de Apelaciones a las decisiones de exclusión probatoria en primera instancia (Duce, 2018).

Existe una gran necesidad de replantear la capacitación a los operadores del sistema de justicia con la finalidad de que se robustezca la audiencia de etapa intermedia, mejorando la calidad de los debates probatorios. Una gran responsabilidad la encontramos en el juez de garantía quien en su rol de gate-keeper debe intensificar el contradictorio entre las partes para que se produzca un debate de mayor intensidad.

Por otro lado, con la finalidad de que la lógica adversarial permita obtener mejores resultados en la calidad del sistema, también se requiere que la Defensa formule una Teoría del Caso propia y que esta se manifieste en la proposición de prueba de descargo para que no se encuentre supeditada a la estrategia y medios probatorios de la Fiscalía. Estos aspectos están condicionados a una serie de necesidades presupuestarias y de fortalecimiento institucional previo en el caso de los defensores públicos.

\section{BIBLIOGRAFÍA}

Binder, A. (1993). Introducción al Derecho Procesal Penal. AD-HOC. Buenos Aires. Argentina.

Binder, A. (2012). La implementación de la nueva justicia penal adversarial. AD-HOC. Buenos Aires. Argentina.

Binder, A. (2014). Elogio de la audiencia oral y otros ensayos. Consejo de la Judicatura del Estado de Nuevo León. México.

Duce, M. (2018). Una aproximación empírica al uso y prácticas de la prueba pericial en el proceso penal chileno a la luz de su impacto en los errores del sistema. Revista Política Criminal, Vol. 113, N. ${ }^{\circ}$ 25. Art. 2, pp. 42-103. 2018

Fandiño, M., Rua, G., Moreno, L. y Fibla, G. (2018). Desafíos de la Reforma Procesal Penal en Chile: Análisis retrospectivo a más de una década. Centro de Estudios de Justicia de las Américas.

Fuchs, M.C., Fandiño, M. y González, L. (2018). La Justicia Penal Adversarial en América Latina. Hacia la gestión del conflicto y la fortaleza de la ley. Centro de Estudios de Justicia de las Américas y Fundación Konrad Adenauer.

González L. (2018). Debates y horizontes de la justicia penal adversarial. Pendiente de publicación.

Ried, I. (2017). La formalización de la investigación como ejercicio de una carga procesal estratégica del Ministerio Público en el proceso penal. Revista de la Justicia Penal, N. ${ }^{\circ}$, págs. 87 y ss.

Rua, G. y González, L. (2018). El rol del juez en un sistema adversarial: Fundamentos y técnicas de conducción de audiencias. En Revista Sistemas Judiciales, Revista N. ${ }^{\circ} 21$, Buenos Aires. 


\title{
O princípio democrático na União Europeia
}

\author{
CARLOS C. PROENÇA'
}

carlosproenca@sapo.pt

GALILEU - REVISTA DE DIREITO E ECONOMIA - e-ISSN 2184-1845

Volume XX $\cdot 1^{\text {st }}$ July Julho $-31^{\text {TH }}$ December Dezembro $2019 \cdot$ pp. 84-100

DOI: http://doi.org/10.26619/2184-1845.XX.2.5

Submitted on September $18^{\text {th }}, 2019 \cdot$ Accepted on November $15^{\text {th }}, 2019$

Submetido em 18 de Setembro, 2019 . Aceite a 15 de Novembro, 2019

RESUMO 1. Introdução; 2. Sentido e alcance do princípio democrático; 3. O princípio democrático enquanto princípio fundamental da União Europeia; 4. A Cidadania Europeia e a consolidação da democracia representativa na União; 5. A democracia positiva e o Parlamento Europeu: procedimento legislativo ordinário e debate de investidura; 6. A democracia negativa e o Parlamento Europeu: o controlo político de outras instituições; 7. O princípio da subsidiariedade e a democracia de proximidade; 8 . O reforço do papel dos Parlamentos nacionais na União Europeia; 9. Cidadania Europeia: o ser ou não ser de uma democracia participativa; 10. Conclusão.

PALAVRaS CHAVE União Europeia, princípio democrático.

ABSTRACT Composed of democratic States, the democratic principle, in order to legitimize public powers, is a fundamental principle of the European Union and its law. Respect for this principle is, on the one hand and first of all, a condition of EU membership, but, on the other hand, it also justified the progressive increase in the powers of the European Parliament (both in political control carried out over other European institutions, as in the adoption of Community legislation), the creation of European citizenship status and the association of national parliaments in the fields of European integration.

KEY WORDS European Union, democratic principle.

1 Professor Universitário na UAL e no ISCAL, e Advogado; Licenciado, Mestre e Doutor em Direito. 


\section{Introdução}

Se em 1947, previamente ao surgimento das Comunidades Europeias ${ }^{2}$, Winston Churchill lançou o gérmen de um princípio democrático de nível europeu, ao propalar "nós não coligamos Estados, nós unimos Homens", ideia retomada por Jean Monnet, em 1952, no discurso de Washington, tal não impediu a ausência de referências ao princípio democrático na versão originária do Tratado da Comunidade Económica Europeia (TCEE) ${ }^{3}$.

Esta circunstância justificava-se por duas razões. Primeira: o processo de integração europeia apresentou-se, num primeiro momento, com um cariz exclusivamente económico $^{4}$, o que, acompanhado de as competências das Comunidades Europeias serem meramente funcionais, justificava a falta de menções à democracia, bem como a mecanismos de concretização da mesma. Segunda: a tentativa inicial, ainda que não admitida pelo menos de forma expressa, de criação de uma Europa vocacionada para os Estados membros, bem como para as instituições comunitárias, deixando de parte, num primeiro estádio, os cidadãos.

Assim, qualquer tentativa de extração do princípio democrático daquele texto, ou pelo menos do projeto europeu de integração, era rebuscada, porquanto muito embora o Preâmbulo do TCEE referisse, nomeadamente, a determinação dos Estados membros em estabelecer "uma união cada vez mais estreita entre os povos europeus", tal princípio não merecia qualquer menção expressa no respetivo articulado.

O marco de viragem do ordenamento jurídico comunitário face a este cenário ocorreu com o Tratado da União Europeia (TUE) $)^{6}$ Um dos slogans transversal às negociações e à assinatura do mesmo, bem assim aos processos de ratificação e ao início da vigência nos então doze Estados membros da UE, foi o da criação de uma Europa dos Cidadãos. O Tratado de Lisboa7 também conferiu um novo impulso à democracia na União.

Este ensaio incide sobre a evolução do princípio democrático de nível europeu, pilar fundamental em que a UE assenta, descrevendo a sua paulatina evolução e consolidação.

2 Comunidade Europeia do Carvão e do Aço - CECA; a Comunidade Económica Europeia - CEE; e a Comunidade Europeia da Energia Atómica - CEEA.

3 Assinado em Roma, pelos seis Estados membros fundadores, a 25 de março de 1957 e em vigor desde 14 de janeiro de 1958.

4 Com efeito, a designação Comunidade Económica Europeia era eloquente para traduzir um processo de integração inicialmente economicista. Cfr. Luís CRUZ-VILAÇA, A protecção dos direitos dos cidadãos no espaço comunitário, in Valores da Europa - Identidade e Legitimidade, Cascais, 1999, p. 51; João MOTA DE CAMPOS, Manual de Direito Comunitário, Lisboa, 2002, p. 235; Rui MOURA RAMOS, Maastricht e os direitos do cidadão europeu, in Das Comunidades à União Europeia, 2. ${ }^{\text {a }}$ ed., Coimbra, 1999, pp. 325 e 326; Maria Luísa DUARTE, A cidadania da União e a responsabilidade dos Estados por violação do Direito Comunitário, Lisboa, 1994, pp. 16 e ss.

5 Tal era e é o $1 .{ }^{\circ}$ considerando, logo a frase de abertura, do Tratado de Roma. Tendo subjacente o princípio democrático, tal excerto foi repetido no artigo $1 .^{\circ}$ do Tratado de Maastricht, assinado volvidos 25 anos.

6 Assinado em Maastricht no dia 7 de fevereiro de 1992, entrou em vigor a 1 de novembro de 1993

7 Celebrado em 13 de dezembro de 2007, iniciou vigência a 1 de dezembro de 2009. 
Cuidaremos das suas principais consagrações e concretizações, e tentaremos extrair o significado do princípio democrático europeu.

\section{Sentido e alcance do princípio democrático}

A essência do princípio democrático traduz-se em duas formulações que, podendo à partida parecer contraditórias, não são. A fórmula clássica, de Abram Lincoln, é positiva ${ }^{8}$ e propõe a democracia como o "governo do povo, pelo povo e para o povo" 9 . A fórmula provocatória, de Karl Popper, é negativa ${ }^{10}$ e propala que "a democracia nunca foi a soberania do povo, não o pode ser, não o deve ser".

Em ambas o princípio democrático aponta, tanto no contexto nacional como no quadro europeu, para a legitimação do poder político. Quer dizer: com ele visa-se responder à seguinte questão: porque há governantes e governados? A resposta aponta - e nisso consiste a verdadeira essência do princípio democrático - para a legitimação popular exercida através (i) do voto (universal, secreto, periódico e igual) para a eleição dos órgãos representativos e (ii) do referendo ${ }^{11}$ sempre que os cidadãos sejam chamados a pronunciar-se diretamente sobre questões de relevante interesse. Isto é, se entendermos o poder como domínio político (ou um domínio legitimado de homens sobre homens) ou como soberania (no sentido da competência para a formação da vontade política de um Estado), o titular desse poder é o povo, daqui se extraindo que o princípio democrático é concretizado pela soberania popular. Daí que aquelas formulações de democracia não sejam contraditórias: ambas defendem que a democracia repousa na legitimação popular já que inexistem outras formas de legitimação, divinas ou partidárias, do poder político. Segundo o princípio democrático, somente a legitimação do povo autoriza o exercício do poder político, pelo que a democracia é, com efeito, o poder e o governo do povo.

Enquanto governo do povo, a democracia manifesta-se através de duas formas.

A forma representativa, que exige órgãos representativos, eleições periódicas, pluralismo partidário e separação de poderes. Ou seja, num sistema político baseado no poder do povo, mas onde nem todos os cidadãos se encontram dotados das características necessárias para saberem dar resposta às aspirações da comunidade, há necessidade de proceder à esco-

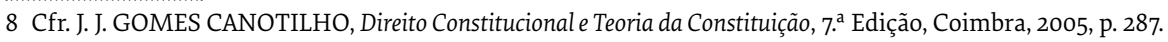

9 Cfr. Ana Maria GUERRA MARTINS, Curso de Direito Constitucional da União Europeia, Coimbra, 2004, p. 213; Leonardo COIMBRA, Dispersos V. Filosofia e Política, Lisboa/São Paulo, 1994, p. 219.

10 Cfr. J. J. GOMES CANOTILHO, Direito..., cit., p. 291.

11 Mecanismo consolidado nos Estados membros e de que foi exemplo a ratificação, pela via referendaria, prevista em vários daqueles Estados, do abandonado Tratado que pretendeu instituir uma Constituição para a Europa. 
lha ou à seleção das pessoas dotadas dessas qualidades, traduzindo-se numa perspetiva de output centrada na representação.

E a forma participativa, que reclama processos que confiram aos cidadãos reais possibilidades de apreender a democracia, participar nos processos decisórios, controlar criticamente divergências de entendimentos ${ }^{12}$. Esta forma preconiza que todos os cidadãos devem participar nos domínios políticos, influenciando-os ou contribuindo para influenciá-los, dando prevalência a uma perspetiva de input, que significa participação e intervenção política direta do povo nos assuntos da polis.

Os sistemas jurídico-constitucionais dos Estados membros têm dado prevalência à visão de output, concentrada na democracia representativa ou na representação democrática, a qual, naturalmente, se alastrou à UE.

Paralelamente àquelas formas, duas conceções correlativas consubstanciam sequelas da prevalência de cada uma daquelas manifestações do princípio sub judice. Na democracia participativa, assente em instrumentos de participação ou em inputs políticos democráticos, predomina uma conceção de democracia positiva, a qual defende a legitimação dos governantes através de eleições, conferidoras de um título legitimador do poder político atribuído aos governantes. Na democracia representativa, baseada em mecanismos que procuram conferir seletividade, representação, racionalidade ao princípio democrático, e orientada por expedientes de outputs, prevalece uma conceção de democracia negativa, que defende a preferência por mecanismos de controlo, fiscalização e revogação dos titulares de cargos políticos. Ambas se afiguram importantes, pois se a montante há necessidade de legitimar o poder político em que investimos os governantes, a jusante exige-se o controlo da sua atuação e do seu desempenho.

\section{O princípio democrático enquanto princípio fundamental da União Europeia}

A democracia apresenta-se um princípio estruturante da UE e um princípio comum aos Estados membros, ou seja, a UE é uma União de Estados democráticos. A principal referência expressa e direta à democracia consta do artigo $2 .^{\circ}$ do TUE, onde se estabelece que a União se funda em vários princípios, entre eles o democrático, os quais são partilhados por todos os Estados membros. Retoma-se no articulado do Tratado um princípio afirmado, antes de mais, no respetivo Preâmbulo, já que os seus considerandos $2 .^{\circ}$ e $4 .^{\circ}$ afirmam o

12 Cfr. J. J. GOMES CANOTILHO, Direito..., cit., p. 288, a propósito da lição sobre o princípio democrático-normativo como princípio complexo. 
apego dos Estados membros a vários princípios nos quais a União se inspira, um dos quais o princípio democrático. A democracia surge, pois, como princípio fundamental da $\mathrm{UE}^{13}$, que, por isso, não comporta a suscetibilidade de derrogação na ordem jurídica interna dos Estados membros ${ }^{14}$.

Se, por um lado, a referida norma determina que a UE se funda na democracia, por outro lado, o considerando $4 .^{\circ}$ do TUE plasma o apego dos Estados membros ao princípio democrático. Estas diferenças traduzem um significado político que assenta na natureza da UE como organização internacional sui generis (e não como um Estado, nomeadamente federal); também não existe um povo europeu, tal como inexiste um governo europeu. Logo, diferentemente do que sucede no âmbito interno (isto é, no quadro dos Estados-nação), no atual estado do processo europeu de integração é prematuro falar-se numa soberania popular europeia. Sem se ignorar a inserção do princípio democrático nos princípios constitucionais da UE, o mesmo apresenta um alcance distinto daquele que lhe é conferido no plano nacional.

Esta ilação extrai-se da decisão de 12 de outubro de 1993, conhecida por acórdão MAASTRICHT, confirmada pelo aresto de 30 de junho de 2009, designado de acórdão LISBOA, ambos proferidos pelo Tribunal Constitucional Federal Alemão (adiante BVerfG), no quadro dos processos de ratificação dos Tratados de Maastricht e de Lisboa, e refletindo o seu ativismo judiciário na posição que marcou a propósito da natureza do processo de integração europeu.

Em especial, o BVerfG recusou a existência de qualquer poder constituinte europeu no âmbito da UE, entendendo tratar-se antes de um poder derivado, já que são os Estados, através dos seus órgãos de soberania, que decidem a adesão àquelas, conservando-se como os "donos do Tratado". Considerou ainda que a integração europeia não poderia levar ao esvaziamento dos poderes do Parlamento Federal e que a faculdade de a Alemanha participar numa comunidade de Estados está condicionada, devendo ser sempre garantida e legitimada pelo povo alemão; o papel dos Parlamentos nacionais será sempre decisivo na transferência de competências para as entidades supranacionais, tendo a extensão das atribuições europeias limites que resultam de não ser possível esvaziar por completo as tarefas nacionais. Dois aspetos particularmente interessantes destes acórdãos foram, por um lado, a negação do caráter federal à UE, entendendo o Tribunal que esta mais não é do que uma

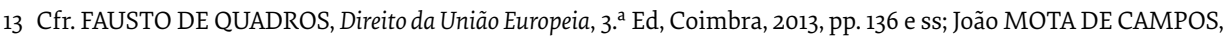
Manual..., cit., pp. 259 e ss.

14 Tal afastamento seria "um atentado inaceitável contra o espírito da União Europeia, na medida em que poria irremediavelmente em causa a homogeneidade e a coesão do bloco de países que dela fazem parte", ensina João MOTA DE CAMPOS, Manual..., cit., p. 259. 
associação de Estados (Staatenverbund) evitando falar em União e até em Comunidade; por outro lado, a consideração de que o processo de integração não é irreversível, podendo a Alemanha sair da UE quando o desejar, estando as futuras transferências de competências e atribuições dependentes da autorização das entidades nacionais.

Estas decisões, no fundo, confirmaram que a UE não é um Estado ${ }^{15}$, já que para o ser teria que deter a competência geral ou a "competência das competências" (Kompetenz-Kompetenz), a qual permanece nos Estados. A União nunca esteve dotada do poder de auto-organização pelo qual elaboraria a sua Constituição, definiria as respetivas atribuições, criaria os seus órgãos e fixar-lhes-ia competência, assim faltando-lhe a primeira característica de um Estado ${ }^{16}$. Tal como são os Estados que detêm, entre outros, o poder de rever os Tratados.

\section{A Cidadania Europeia e a consolidação da democracia representativa na União}

Com a entrada em vigor do Tratado de Maastricht os Estados membros das Comunidades instituíram a UE, a qual, até à entrada em vigor do Tratado de Lisboa, assentou numa peculiar estrutura de três pilares, cada um com os seus objetivos e instrumentos próprios ${ }^{17}$.

O TUE também criou a Cidadania Europeia ${ }^{18}$. Em concretização do (novo) objetivo de reforço da defesa dos direitos e dos interesses dos nacionais dos Estados membros, então previsto no $3 .^{\circ}$ travessão do artigo $2 .^{\circ}$ do TUE, consagrou-se pela primeira vez ao nível do direito primário um estatuto comum aos nacionais dos Estados membros lapidarmente denominado de Cidadania da União, traduzindo um assinalável reforço da democracia na UE ${ }^{19}$. Tal Tratado alterou

15 Vide FAUSTO DE QUADROS, Direito..., cit., pp. 134 e ss. e 238 e ss.

16 Cfr. FAUSTO DE QUADROS, Direito..., cit., p. 139; Maria Luísa DUARTE, A teoria dos poderes implícitos e a delimitação de competências entre a União Europeia e os Estados membros, Lisboa, 1997, pp. 220, 221 e 484; J. J. GOMES CANOTILHO, Direito..., cit., pp. 58 e 70; Jorge MIRANDA, O Direito Constitucional Português da Integração Europeia. Alguns aspectos, in AAVV, Nos 25 anos da Constituição da República Portuguesa de 1976. Evolução constitucional e perspectivas futuras, Lisboa, 2001, pp. 16 a 26.

17 Com efeito, a União fundava-se nas três Comunidades Europeias, que constituíam o pilar de integração (ou primeiro pilar), complementadas pelos pilares intergovernamentais: a PESC (segundo pilar) e a CJAI (terceiro pilar), esta posteriormente reduzida à Cooperação Policial e Judiciária em Matéria Penal em virtude da comunitarização parcial do terceiro pilar operada pelo Tratado de Amesterdão, porquanto as matérias relativas a vistos, asilo e imigração e outras políticas relativas à livre circulação de pessoas passaram a relevar ao nível do primeiro pilar e ao método da integração supranacional. O Tratado de Lisboa pôs fim a essa estrutura, pelo menos do ponto de vista formal. Cfr. FAUSTO DE QUADROS, Direito..., cit., p. 157.

18 Uma vez que as atribuições da anterior CEE, além de económicas, eram também de outras naturezas, como sociais, culturais e políticas, o TUE alterou ainda designação daquela para CE, a que não foi alheio o instituto da Cidadania da União.

19 Cfr. FAUSTO DE QUADROS, Direito..., cit., p. 158; João MOTA DE CAMPOS, Manual..., cit., pp. 239 e ss.; Rui MOURA RAMOS, op. cit., pp. 327, 328, e 346. Falando no instituto da Cidadania da União enquanto mecanismo 
qualitativamente a liberdade de circulação de pessoas e transpôs a ótica meramente económica em que assentava o mercado comum tal como inicialmente concebido pelo Tratado de Roma ${ }^{20}$. No campo da Cidadania da União, o atual Tratado sobre o Funcionamento da UE (TFUE; ex-Tratado da Comunidade Europeia - TCE) concede aos nacionais dos Estados membros o direito de circulação e permanência livre no território daqueles enquanto espaço sem fronteiras internas, independentemente do exercício de qualquer atividade profissional' ${ }^{21}$.

A nova configuração da liberdade de circulação de pessoas, emancipada de uma ótica integrativa de raiz economicista, dificilmente poderia deixar de ser acompanhada da atribuição aos cidadãos da União de direitos, não apenas de caráter económico e social, mas também político, que lhes permitissem sentir-se como participantes de pleno direito de um processo de integração evolutivo ${ }^{22}$. Daí o estatuto de cidadania da União atribuir aos cidadãos europeus residentes em Estados membros que não sejam os das suas nacionalidades, em decorrência do princípio da não discriminação em razão da nacionalidade, dois direitos públicos de participação política eleitoral: os de elegerem e serem eleitos nas eleições para o Parlamento Europeu (PE) e nas eleições municipais dos Estados membros de residência nas mesmas condições que os nacionais destes Estados ${ }^{23}$. Tais prerrogativas contribuíram para a consolidação do princípio democrático na UE, porquanto, tratando-se de direitos de participação política, reforçaram o sentimento de identificação dos cidadãos europeus com o Estado membro onde residem (por via da participação eleitoral autárquica)

concretizador de um sentido restrito de cidadania, ao qual se contrapõe uma aceção ampla de cidadania europeia, composta não apenas pelos direitos civis e políticos enunciados nos artigos $20 .^{\circ}$ a $24 .^{\circ}$ do TFUE, mas por todos os direitos de que são titulares os nacionais dos Estados membros da UE e cuja fonte é tanto o direito originário como o derivado, ver Marcelo REBELO DE SOUSA, A cidadania Europeia - Nível de concretização dos direitos, possibilidade de alargamento e suas implicações, in Em torno da revisão do Tratado da União Europeia, Coimbra, 1997, pp. 119, 120, e 127 e ss.

20 Merecem referência as conclusões que o Advogado-geral JACOBS teceu no caso BICKEL E FRANZ, que originou o acórdão do Tribunal de Justiça de 24 de novembro de 1998, processo C-274/96, Col. 1998, pp. 7645 e ss: "a noção de cidadania da União implica uma comunidade de direitos e obrigações que unem os cidadãos da União por um vínculo comum que transcende a nacionalidade de um Estado membro. A introdução deste conceito foi largamente inspirada pela preocupação de aproximar a União dos seus cidadãos e de exprimir a sua natureza como algo diverso de uma União puramente económica. Esse intento encontra-se reflectido no abandono da expressão «económica» na denominação da Comunidade e pela progressiva introdução, no Tratado CE, de um amplo conjunto de actividades e de políticas que extravasam do âmbito económico".

21 Cfr. Ana Maria GUERRA MARTINS, Curso..., cit., p. 189.

22 Cfr. João MOTA DE CAMPOS, Manual..., cit., p. 236. Assiste-se aqui àquilo que Boaventura SOUSA SANTOS chamaria de "paradigma emergente", enquanto uma ampla expansão e dispersão do direito democrático e da cidadania. Ver Crítica da razão indolente. Contra o desperdício da experiencia, Porto, 2002, p. 315.

23 Também aqui surge plasmado o princípio do tratamento nacional. Neste sentido Miguel GORJÃO-HENRIQUES,

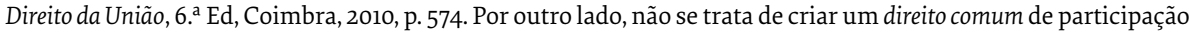
política com o mesmo conteúdo no território dos Estados, mas sim de assimilar o cidadão residente num Estado membro aos nacionais respetivos. Assim Rui MOURA RAMOS, op. cit., p. 351. 
bem como com a UE (através da participação eleitoral para o PE). Da alínea b) do n. ${ }^{0} 2$ do artigo $20 .^{\circ}$ do TFUE decorre que o critério de participação naqueles escrutínios deixou de ser exclusivamente o da nacionalidade, para ser também o da residência ${ }^{24}$. Destaque merece ainda a equiparação, para este efeito, entre as capacidades eleitorais ativa (direito de eleger) e passiva (direito de ser eleito). Ambos os direitos inserem-se na dimensão representativa do princípio democrático, já que aquelas prerrogativas acolhem recortes dos mais importantes postulados da teoria democrática representativa (órgãos representativos, eleições periódicas e pluralismo partidário). Não obstante, os Estados membros também tiveram em conta a necessidade de conferir eficiência, seletividade e racionalidade ao referido princípio, a que não foi imune uma orientação de output do mesmo.

A nova configuração da forma de participação dos cidadãos da União nas eleições para o PE constitui um assinalável reforço da legitimidade democrática desta instituição. A novidade não reside na eleição por sufrágio direto e universal ${ }^{25}$, mas sim na aquisição de ambas as capacidades eleitorais pelo critério do Estado membro de residência, representando um plus para a dimensão representativa pluralista do princípio democrático na UE. Este direito implica, maxime no que tange à capacidade eleitoral passiva, a participação direta dos cidadãos europeus nas prerrogativas do poder político do Estado de residência através da instituição europeia (a única dotada de legitimidade democrática $\operatorname{direta}^{26}$ ) que participa nos procedimentos decisórios de aprovação de legislação comunitária (v.g. regulamentos e diretivas).

Os direitos de eleger e de ser eleito nas eleições locais do Estado de residência espelham que a participação nos assuntos políticos europeus não se cinge à União, considerada distintamente dos Estados que a compõem ${ }^{27}$. Tratando-se da participação nas eleições autárquicas, está em causa a escolha dos titulares dos órgãos do poder local dos Estados

24 Como observa Rui MOURA RAMOS, op. cit., p. 350, esta norma veio “integrar os cidadãos da União residentes num dado Estado membro no respectivo povo, independentemente da posse da nacionalidade respectiva, ao menos no que releva para os efeitos da eleição do Parlamento Europeu".

25 Nem sempre assim aconteceu. Desde a criação das Comunidades e durante mais de 20 anos, os membros do $\mathrm{PE}$, então delegados (e não deputados), eram nomeados pelos Parlamentos nacionais e escolhidos de entre os seus membros (e não eleitos pelos povos dos Estados). Remonta a 1975 a primeira concretização relevante, expressa num relatório da Comissão, do ensejo de o PE ser composto por representantes dos povos eleitos por sufrágio universal, a qual mereceu a concordância desta instituição. Em 20 de setembro de 1976 o Conselho aprovou os textos relativos à eleição dos membros do PE por sufrágio universal e secreto, os quais foram objeto de ratificação, pelos Estados membros, em conformidade com as respetivas normas constitucionais. A primeira eleição dos membros do PE ocorreu, simultaneamente em toda a Comunidade, em 10 de junho de 1979, o que contribuiu não só para o reforço da legitimidade do $P E$, na medida em que a mesma passou a ser direta, como também para se ascender à Europa dos povos. Cfr. Giancarlo OLMI, Introdução, in Trinta anos de Direito Comunitário, Bruxelas, 1981, pp. 11 e 12; Guy SCHRANS, A Comunidade e as suas instituições, in Trinta anos..., cit., pp. 28 a 30.

26 Na síntese de RUI MOURA RAMOS, op. cit., p. 333, o PE trata-se de uma instituição que deve a sua existência a uma manifestação da vontade dos cidadãos europeus.

27 Cfr. Rui MOURA RAMOS, op. cit., p. 350. 
membros e nelas podem participar os cidadãos europeus que aí residam. Em Portugal, a Constituição prevê a capacidade eleitoral dos estrangeiros residentes em Portugal para a eleição dos titulares de órgãos autárquicos desde a revisão constitucional de 1989, tendo a revisão de 1992 esclarecido que tal capacidade eleitoral é ativa e passiva ${ }^{28}$.

\section{A democracia positiva e o Parlamento Europeu: procedimento legislativo ordinário e debate de investidura}

A conceção positiva de democracia assume maior importância se tivermos presente que o PE tem aumentado os seus poderes consideravelmente ao longo dos mais de cinquenta anos do processo europeu de integração.

Em matéria de procedimentos decisórios de adoção dos atos europeus (entre os quais, legislativos) de direito derivado previstos no Tratado de Roma, evoluiu-se de um processo em que o PE era apenas consultado para um processo de cooperação e mais tarde de codecisão, com o Tratado de Lisboa renomeado de processo legislativo ordinário e elevado a procedimento decisório-regra ${ }^{29}$ na adoção de atos pelas instituições europeias ${ }^{30}$. Se nos dois primeiros o Parlamento era apenas ouvido, não conseguindo impedir o Conselho de adotar propostas ${ }^{31}$, no atual quadro o $\mathrm{PE}$ "logrou, finalmente, o estatuto há muito tempo reivindicado de órgão decisor em domínios fundamentais da regulação comunitária" ${ }^{32}$. Com efeito, neste procedimento o poder decisório é repartido entre o Parlamento e o Conselho, o que obriga a uma aproximação e à obtenção de consensos para que as propostas se concretizem em atos. Nesta evolução é visível o aumento da legitimidade democrática na tomada de decisões, o que incrementa a importância da eleição direta do $\mathrm{PE}$, bem como da extensão da capacidade eleitoral aos cidadãos europeus residentes num Estado membro do qual não são nacionais, vislumbrando-se um relevante passo no processo europeu de integração no que concerne à consolidação do princípio democrático.

O papel do PE na investidura dos membros da Comissão Europeia, incluindo o seu Presidente, também releva na efetivação democrática na União e, nele, também se vislum-

28 O mesmo acontecia na Dinamarca, na França e no Luxemburgo, países nos quais o direito interno já reconhecia a não nacionais (não necessariamente com a nacionalidade de outro Estado membro da UE, note-se) capacidade eleitoral ativa e passiva nas eleições autárquicas.

29 Cfr. artigos $289 .^{\circ}$ e $294 .^{\circ}$ do TFUE.

30 Sobre os procedimentos decisórios ver Maria Luísa DUARTE, Direito da União Europeia e das Comunidades Europeias, Vol. I, Tomo I, Lisboa, 2001, pp. 223 e ss.

31 De facto, no processo de consulta o PE limita-se a emitir um parecer que não é vinculativo; e no procedimento de cooperação, o "melhor" a que o PE poderia aspirar era, mediante rejeição da posição comum do Conselho, forçar esta instituição a deliberar por unanimidade, caso a mesma pretendesse a aprovação do ato.

32 Assim Maria Luísa DUARTE, Direito..., cit., p. 242. 
bra um traço da conceção positiva de democracia. Obtido o consenso no Conselho Europeu relativamente à personalidade a nomear Presidente da Comissão, é imprescindível que tal nomeação seja aprovada, mediante sufrágio, pelo PE. No debate de investidura que antecede a votação, a personalidade indicada deve responder satisfatoriamente às perguntas colocadas pelos deputados europeus e cujo objeto se prende com as orientações e o rumo político pretendido caso seja designada. Eleita a personalidade, segue-se a escolha dos restantes comissários (entre eles o Alto Representante da União para os Negócios Estrangeiros e Política de Segurança), onde participam o Conselho (ou novamente o Conselho Europeu no caso do Alto Representante) e o recém-eleito Presidente da Comissão. A lista dos futuros comissários é submetida a nova aprovação, agora colegial ${ }^{33}$, designada de voto de aprovação parlamentar, após o que se segue a nomeação definitiva do colégio de comissários pelo Conselho Europeu. Através destas competências, o PE contribui para a legitimidade democrática, ainda que indireta, da Comissão.

\section{A democracia negativa e o Parlamento Europeu: o controlo político de outras instituições}

A conceção negativa de democracia também está presente na UE, nomeadamente nos mecanismos de que o $\mathrm{PE}$ dispõe para controlar politicamente outras instituições.

A moção de censura, prevista nos artigos $17 .^{\circ}$, n. ${ }^{\circ} 8$, do TUE e $234 .^{\circ}$ do TFUE (e $119 .^{\circ}$ do Regimento Interno do PE), ocupa um papel primordial nos instrumentos de controlo, fiscalização e de revogação. Caso seja adotada por maioria de dois terços dos votos expressos desde que represente a maioria dos 751 membros que compõem o Parlamento, a Comissão é forçada a cessar funções coletivamente.

Importantes afiguram-se, também, o expediente das questões orais e escritas e o mecanismo das comissões de inquérito. Nos termos do artigo $230 .^{\circ}$ do TFUE (conjugado com os artigos $128 .^{\circ}$ e seguintes do Regimento do PE), a Comissão e o Conselho devem responder às questões colocadas pelo $\mathrm{PE}$ ou pelos seus deputados. $\mathrm{O}$ artigo $226 .^{\circ}$ do TFUE (e 198. ${ }^{\circ}$ do Regimento) possibilita ao PE, a pedido de um quarto dos seus membros, determinar a constituição de comissões parlamentares de inquérito para analisar infrações ou situações de má administração na aplicação do direito da UE, contando que os factos

33 Afigura-se importante salientar que desde janeiro de 1995, por altura da aprovação da Comissão liderada por Jacques Santer, o PE, previamente ao voto de aprovação parlamentar que se dirige ao colégio de comissários, submete a audições individuais cada comissário indigitado, mecanismo prévio de controlo inspirado no sistema de «hearings» do Senado norte-americano e semelhante ao que ocorre previamente com o Presidente da Comissão. 
não sejam objeto de um processo judicial, resultantes de atos das instituições, dos órgãos ou organismos da União, da administração pública de um Estado membro ou de pessoas incumbidas aplicação pelo direito da UE.

Os direitos de petição ao PE e de queixa ao Provedor de Justiça Europeu, direitos públicos de participação política (e cívica) não eleitoral decorrentes da cidadania da União, também contribuem para a fiscalização dos titulares de cargos políticos nas instituições europeias. Se os restantes direitos que integram o estatuto de cidadania da União têm um conteúdo substantivo, nestes dois destaca-se a natureza adjetiva, instrumental ou procedimental ${ }^{34}$, porquanto se trata de mecanismos de garantia graciosa ${ }^{35}$. Previstos na alínea d) do n. ${ }^{\circ} 2$ do artigo $20 .^{\circ}$ e nos artigos $227 .^{\circ}$ e $228 .^{\circ}$ do TFUE, trata-se de direitos onde, embora prevaleça a ótica de output-representação ${ }^{36}$, se vislumbra um resquício da visão de input-participação, pois, não obstante possam destinar-se também ao controlo, quiçá à revogação do mandato de algum titular de um cargo político, os mesmos podem ser despoletados pelos cidadãos europeus, embora não exclusivamente pois também radicam em qualquer outra pessoa singular ou coletiva com residência ou sede estatutária num Estado membro ${ }^{37}$.

\section{O princípio da subsidiariedade e a democracia de proximidade}

Genericamente, o princípio da subsidiariedade radica na repartição de atribuições entre várias comunidades e visa a descentralização na comunidade menor das funções da comunidade maior ${ }^{38}$. Esta só poderá prosseguir atribuições daquela se a mesma se mostrar incapaz de as realizar melhor. As comunidades encontram-se, assim, organizadas de forma escalonada ou piramidal, encontrando-se o Estado no topo ${ }^{39}$. Apesar da sua inspiração federal $4^{40}$, o princípio da subsidiariedade não é apanágio dos Estados federais, como bem se demonstra, entre nós, no artigo $6 .^{\circ}, \mathrm{n} .^{\circ}$ 1, da CRP. Classicamente, o princípio da subsidia-

34 Assim FAUSTO DE QUADROS, Direito..., cit., p. 164; também Rui MOURA RAMOS, op. cit., p. 340.

35 Os quais acrescem aos mecanismos do contencioso comunitário há muito existentes.

36 Miguel GORJÃO-HENRIQUES, op. cit., p. 576, apelida-os de direitos de "controlo democrático" dos órgãos comunitários.

37 Trata-se de direitos que ultrapassam a circunscrição decorrente do estatuto de cidadania, o que é compreensível se considerarmos que o que releva aqui, mais do que o estatuto de cidadão, é a qualidade de administrado. Por outro lado, com Maria Luísa DUARTE, Direito..., cit., p. 197, os princípios da legalidade europeia e da transparência também subjazem a este alargamento da legitimidade.

38 Cfr. FAUSTO DE QUADROS, O princípio da subsidiariedade no Direito Comunitário após o Tratado da União Europeia, Coimbra, 1995, pp. 17 e 18; Ana Maria GUERRA MARTINS, O Tratado da União Europeia. Contributo para a sua compreensão, Lisboa, 1993, p. 36.

39 Para Jacques DELORS, a subsidiariedade manifesta-se de duas formas distintas: por um lado, na delimitação da esfera de atuação do Estado, entendido na sua aceção lata; por outro, na repartição de atribuições entre os diferentes níveis do poder político. Cfr. Le nouveau concert européen, Paris, 1992, p. 163.

40 Cfr. João MOTA DE CAMPOS, Manual..., cit., p. 269. 
riedade recusa o monopólio da Administração na prossecução do interesse público ${ }^{41}$, preferindo a prossecução deste pelos corpos sociais que se situam entre o Estado e o cidadão, o que concretiza um princípio de participação e constitui uma manifestação da democracia $^{42}$. Os termos descentralizar e movimento ascendente fazem parte da sua essência ${ }^{43}$. A intervenção da comunidade maior justifica-se pela (i) necessidade e pela (ii) melhor eficácia na prossecução da atribuição em causa ${ }^{44}$, as quais constituem os requisitos concretizadores da aplicação do princípio ${ }^{45}$.

O Tratado de Maastricht institucionalizou o princípio da subsidiariedade no direito comunitário ${ }^{46}$ mediante a cláusula geral inserida no $2 .^{\circ}$ parágrafo do artigo $3 .^{\circ}$-B (renumerado de artigo $5 .{ }^{\circ}$ com o Tratado de Amesterdão) do TCE ${ }^{47}$, a qual, confirmando os dois requisitos de que depende o respeito do referido princípio ${ }^{48}$, pressupunha a relação entre dois níveis distintos de comunidades humanas e visava a repartição das atribuições entre os Estados membros e a CE, ou, mais rigorosamente, a regulação do exercício daquelas atribuições. Tal não significava, porém, que a subsidiariedade só operasse no âmbito de atuação da aludida Comunidade ${ }^{49}$, sendo os seus contornos delimitados pelo quadro global de atividade

41 Jacques DELORS, op. cit., p. 165, destaca que a subsidiariedade não se traduz apenas num limite à intervenção da entidade superior, mas também numa obrigação de esta agir com respeito pelos níveis decisórios inferiores.

42 FAUSTO DE QUADROS, O princípio..., cit., p. 18.

43 Todavia, refira-se que há outra corrente doutrinária (entre nós, João MOTA DE CAMPOS, Manual..., cit., pp. 269 e 270) que defende que o princípio da subsidiariedade permite o contrário, ou seja, a centralização, operando como um movimento descendente, uma vez que os Estados membros devem transferir para a UE todas as tarefas que esta esteja em condições de realizar melhor do que os Estados isoladamente. Cfr. FAUSTO DE QUADROS, $O$ princípio..., cit., p. 32; Ana Maria GUERRA MARTINS, O Tratado..., cit., p. 40.

44 A este propósito Ana Maria GUERRA MARTINS, O Tratado..., cit., p. 44, propõe o recurso a dois testes: o teste da eficácia comparativa (pelo qual se averigua se existem meios disponíveis por parte dos Estados para atingir os objetivos da ação prevista) e o teste do valor acrescentado (mediante o qual se avalia a eficácia da ação comunitária, a dimensão, os problemas transfronteiriços ou os custos da inação).

45 Ver Jacques DELORS, op. cit., p. 165.

46 Apesar de ele já se vislumbrar no horizonte da integração europeia antes deste marco histórico, foram, no entanto, os trabalhos preparatórios do TUE que propuseram a elevação da subsidiariedade a princípio fundamental da integração europeia, sobretudo após o Relatório Giscard d'Estaing, aprovado por Resolução do PE de 12 de junho de 1990, e depois do Conselho Europeu de 14 e 15 de dezembro de 1990 que, convocando duas Conferências Intergovernamentais (uma sobre a União Política e a outra sobre a União Económica e Monetária), sublinhou o significado que deveria ser conferido ao princípio da subsidiariedade nos trabalhos daquelas conferências.

47 A cláusula geral não esgotava, contudo, a institucionalização do princípio da subsidiariedade nos Tratados, uma vez que ela era completada por outras concretizações decorrentes do mesmo princípio, umas constantes do Preâmbulo do TUE, outras presentes em alguns artigos do mesmo Tratado (por exemplo, no artigo B), outras visíveis em preceitos do TCE. Cfr. Ana Maria GUERRA MARTINS, O Tratado..., cit., p. 41; FAUSTO DE QUADROS, O princípio..., cit., pp. 34 a 36.

48 Os quais também constavam do $5 \cdot^{\circ}$ parágrafo do primeiro Protocolo relativo à aplicação dos princípios da subsidiariedade e da proporcionalidade, inicialmente anexo ao TCE e adotado pela CIG que aprovou o Tratado de Amesterdão.

49 Cfr. FAUSTO DE QUADROS, O princípio..., cit., p. 33; Direito..., cit., p. 402; Ana Maria GUERRA MARTINS, O Tratado..., cit., p. 41; Miguel GORJÃO-HENRIQUES, op. cit., p. 384. 
da UE, constituindo, portanto, um princípio fundamental de toda a União e não apenas da $C E^{50}$, o que era confirmado pelo último parágrafo do artigo $2 .^{\circ}$ do TUE, que vinculava a União ao respeito pelo princípio da subsidiariedade na prossecução dos seus objetivos. Precisamente por isso, o Tratado de Lisboa transferiu a cláusula geral de subsidiariedade para o artigo $5 .^{\circ}$ (n. ${ }^{\circ}$ ) do TUE.

A Conferência Intergovernamental (CIG) que aprovou o Tratado de Lisboa também estabeleceu um novo Protocolo anexo ao TUE, ao TFUE e ao TCEEA relativo aos princípios da subsidiariedade e da proporcionalidade, o qual obriga as instituições europeias ao respeito contínuo de tais princípios, maxime no âmbito dos procedimentos de aprovação de atos legislativos da União, fundamentando em que medida os inerentes projetos respeitam ambos os princípios, e associa os Parlamentos nacionais à fiscalização política do respeito pelos mesmos ${ }^{51}$, em claro reforço do princípio democrático na UE.

Quanto à sua dinâmica, naturalmente o campo de atuação do princípio da subsidiariedade prende-se com os domínios que não sejam das atribuições europeias exclusivas, porquanto nestas $^{52}$ a União, atuando mediante políticas comuns, já se substituiu aos Estados; portanto, o princípio da subsidiariedade apenas opera no âmbito de atribuições concorrentes ou paralelas entre a UE e os Estados membros, isto é, que possam ser prosseguidas por ambos, priorizando ou preferindo a intervenção dos Estados ${ }^{53}$. A União só deverá substituir-se aos Estados membros quando a ação prevista tenha dimensão e eficácia a uma escala tendencialmente europeia ou, pelo menos, transnacional; ou seja, a ação empreendida a nível nacional (central, regional ou local) ou, pela negativa, a ausência de uma ação a nível europeu, é contrária às exigências do TFUE ${ }^{54}$ ou lesa significativamente os interesses dos Estados; trata-se, no entanto, de um problema cuja resposta será casuística. Para se reduzir a elevada dose de discricionariedade que o princípio da subsidiariedade confere às instituições europeias exige-se que na fundamentação dos atos, inclusivamente nos respetivos

50 Cfr. FAUSTO DE QUADROS, o princípio..., cit., p. 33.

51 Tal controlo tem lugar a montante, pelo que o seu principal objetivo reside na prevenção de violações ao princípio. O artigo $6 .^{\circ}$ do novo Protocolo atribui aos Parlamentos nacionais o poder de intervirem no decurso do processo legislativo quando entenderem que as propostas de atos não respeitam o princípio da subsidiariedade. Para o efeito, qualquer Parlamento nacional pode, no prazo de oito semanas a contar da data de envio de um projeto de ato legislativo, dirigir aos Presidentes do Conselho, da Comissão e do PE um parecer fundamentado no qual exponha os motivos pelos quais considera que o projeto desrespeita o princípio da subsidiariedade. É o designado mecanismo de alerta rápido.

52 Política comercial comum, política agrícola comum, política comum de pescas, etc.

53 Cfr. Vlad CONSTANTINESCO, Le principe de subsidiarité: un passage obligé vers l'Union Européenne, in Mélanges en hommage à Jean Boulouis, Paris, 1991 pp. 44 e 45; FAUSTO DE QUADROS, Direito..., cit., p. 140; O princípio ..., cit., pp. 43 e 44.

54 Provocando, por exemplo, distorções na concorrência ou restrições às trocas comerciais. 
projetos ou propostas, se motive ou justifique a intervenção da UE em detrimento da atuação dos Estados membros.

Por outro lado, em matéria de atos de direito derivado previstos no artigo $288 .^{\circ}$ do TFUE, verifica-se uma preferência das diretivas sobre os regulamentos, na medida em que as primeiras consubstanciam atos normativos que melhor respeitam o princípio da subsidiariedade ${ }^{55}$.

A subsidiariedade foi o preço pago pelos Estados mais integracionistas pelo alargamento dos objetivos da UE e dos meios necessários à sua realização ${ }^{56}$. Como ensina J. J. GOMES CANOTILHO, por de trás do mencionado princípio está "a ideia de freio e balanço relativamente a um crescente «centralismo europeu»; a ideia de «regionalizar» mais fortemente os processos de decisão comunitária" ${ }^{57}$. Contudo, a principal apreensão subjacente ao princípio da subsidiariedade encontra-se intimamente ligada com o princípio democrático: nele avulta a aproximação do poder dos cidadãos e a necessidade de encontrar decisões mais próximas deles. Pretende-se, em suma, alcançar uma democracia da proximidade ${ }^{58}$, propalada na parte final do $2 .^{\circ}$ parágrafo do artigo $1 .^{\circ}$ e na segunda parte do $n .{ }^{\circ} 3$ do artigo $10 .^{\circ}$ do TUE, ao exortarem à tomada de decisões de forma mais aberta e próxima dos cidadãos. Associado a essa democracia de proximidade vislumbra-se um pluralismo democrático assente na salvaguarda das identidades nacionais dos Estados membros ${ }^{59}$, prevista no n. ${ }^{\circ} 2$ do artigo $4 .^{\circ}$ do mesmo Tratado, objetivo igualmente prosseguido pela ideia de subsidiariedade.

\section{O reforço do papel dos Parlamentos nacionais na União Europeia}

A consolidação da democracia na UE também ocorreu através da associação dos Parlamentos nacionais aos domínios de intervenção daquela, aspeto decisivo na (i) redução do indesejado défice democrático na ação da União, no (ii) aumento da transparência da UE e das respetivas instituições, e na (iii) aproximação do projeto europeu aos cidadãos.

A participação dos Parlamentos no controlo político do respeito pelo princípio da subsidiariedade, igualmente decorrente do princípio do respeito das identidades nacionais, é confirmada no Protocolo anexo ao TUE, ao TFUE e ao TCEEA, relativo ao papel dos Par-

55 Assim Jacques DELORS, op. cit., pp. 170 e 171. O autor chama a atenção para um mau uso do princípio da subsidiariedade pelos Estados membros, visível num crescente esvaziamento da distinção entre estes dois atos, uma vez que ultimamente têm surgido diretivas que se assemelham a regulamentos já que o seu conteúdo se caracteriza pelo excesso de detalhe e pela ausência de concessão aos Estados de espaço de manobra na sua transposição.

56 Assim Ana Maria GUERRA MARTINS, O Tratado..., cit., p. 49.

57 Cfr. Direito..., cit., p. 366.

58 A expressão é de J. J. GOMES CANOTILHO, Direito..., cit., p. 366.

59 Cfr. FAUSTO DE QUADROS, Direito..., cit., p. 142. 
lamentos nacionais na UE, aprovado pela CIG que adotou o Tratado de Lisboa ${ }^{60}$ (artigo $3 .^{\circ}$ ). Nele, os Parlamentos nacionais são associados ao controlo da ação governamental em matéria europeia ${ }^{61}$ mediante a transmissão dos projetos de atos legislativos europeus ${ }^{62}$ (artigo $2^{\circ}{ }^{\circ}$ ). Prevê-se também o estabelecimento de uma cooperação interparlamentar entre o PE e os Parlamentos nacionais regular e eficaz ao nível da União (artigo 9. ${ }^{\circ}$ ), no âmbito da qual a Conferência dos Órgãos dos Parlamentos Nacionais especializados em Assuntos Europeus (COSAC) pode dirigir às instituições europeias participantes nos processos decisórios (Comissão, Conselho e PE) contributos adequados sobre a atividade legislativa da União nos mais variados domínios (v.g. espaço de liberdade, segurança e justiça; direitos, liberdades e garantias individuais; direitos fundamentais em geral; etc.).

\section{Cidadania Europeia: o ser ou não ser de uma democracia participativa}

Outra dimensão do princípio democrático tem em vista a vertente de participação, que implica o exercício direto da cidadania e a mobilização dos cidadãos no produto final da decisão democrática, assim legitimando os próprios decisores ${ }^{63}$.

A prevalência da dimensão democrática representativa no desenvolvimento do funcionamento da UE, expressamente assumida no n. ${ }^{\circ} 1$ do artigo $10 .^{\circ}$ do TUE, é inequívoca. Ao longo da evolução do processo europeu de integração os Tratados preocuparam-se em consolidar a dimensão representativa do princípio democrático. Assim, aquele processo caracteriza-se, igualmente, por um défice no que tange aos instrumentos da dimensão participativa do mesmo princípio, constatando Boaventura de SOUSA SANTOS ${ }^{64}$ que os domínios da UE são um bom exemplo de uma área social que situada fora da intervenção participativa dos cidadãos em virtude de aí se verificar uma redução da política a uma prática social setorial e especializada e na rígida regulação da participação dos cidadãos nessa prática.

60 O qual substituiu o anterior Protocolo referente à mesma matéria, anexo ao TUE, ao TCE e ao TCEEA, adotado pela CIG que aprovou o Tratado de Amesterdão. Em ambos os Protocolos os Estados membros afirmaram a sua vontade em "incentivar uma maior participação dos Parlamentos nacionais nas actividades da União Europeia e reforçar a capacidade de exprimirem as suas opiniões sobre questões que para aqueles possam revestir especial interesse".

61 Cfr. FAUSTO DE QUADROS, Direito..., cit., p. 403; Ana Maria GUERRA MARTINS, Curso..., cit., p. 93.

62 Assemelhando-se a Comissão (autora da esmagadora maioria das propostas de atos legislativos europeus, bem como de alguns regulamentos de execução e regulamentos delegados) a um Executivo europeu, estamos diante de um instrumento de controlo político dos Parlamentos nacionais sobre tal Executivo, o que traduz um plus face ao controlo político que o PE exerce sobre a Comissão e sobre a ação dos respetivos Governos nacionais em matéria europeia, uma vez que no Conselho, composto por representantes dos Estados membros ao nível ministerial, reside a competência decisória.

63 Cfr. Fernando RUIVO, Cidadania activa, movimentos sociais e democracia participativa, in RCCS, n. ${ }^{\circ}$ 54, 1999 , p. 174.

64 Cfr. op. cit., p. 105 
Será, por isso, legítimo questionar onde paira, na UE, a democracia participativa?

No atual estádio da integração o mencionado défice não é sinónimo de total ausência dessa dimensão do princípio democrático. Dúvidas não se levantarão, porém, quanto ao facto de muito estar ainda por fazer. O direito de petição ao PE e o direito de queixa ao Provedor de Justiça Europeu, também integrantes do estatuto da cidadania da União, serão dois mecanismos precursores da dimensão participativa do princípio democrático em que a UE assenta. Acresce uma novidade introduzida pelo Tratado de Amesterdão: a faculdade de os cidadãos europeus se dirigirem, por escrito, às instituições da UE numa das línguas previstas no $n .^{\circ} 1$ do artigo $55 .^{\circ}$ do TUE e o direito de obterem do destinatário uma resposta, também por escrito, na mesma língua ( $4 .^{\circ}$ parágrafo do artigo $24 .^{\circ}$ do TUE).

Todavia, inexiste a figura do referendo europeu, expressão da democracia semidiret $a^{65} \mathrm{e}$ do envolvimento imediato dos cidadãos da UE, mediante consulta popular aos povos dos Estados membros sobre questões de relevante interesse europeu inseridas na esfera de atribuições da União, o que contribui para alguma neutralização da capacidade emancipatória do princípio democrático enquanto traço político marcante da $\mathrm{UE}^{66}$.

O Tratado de Lisboa deu importantes passos nesse caminho. O n. 3 do artigo $10 .^{\circ}$ do TUE introduz, prima facie, o direito de todos os cidadãos a "participar na vida democrática da União", aqui residindo um gérmen programático de mecanismos de democracia participativa no seio da UE; mais se acrescenta que "as decisões são tomadas de forma tão aberta e tão próxima dos cidadãos quanto possível". Eloquente é também o novo n. ${ }^{\circ} 4$ do artigo $11 .^{\circ}$ do TUE, ao prever o direito de os cidadãos convidarem a Comissão a apresentar propostas de atos de direito derivado ( $v . g$. de regulamentos e de diretivas) em matérias nas quais

65 Assim J. J. GOMES CANOTILHO, Direito..., cit., pp. 294 e ss.

66 Em 2004, na assinatura do Tratado que institui uma Constituição para a Europa, os Estados membros assumiram o compromisso assinalável de ratificar aquele Tratado por via referendária. Não se tratou de um referendo europeu, mas de vários referendos nacionais sobre uma questão comum. Entre nós, em 2005, a CRP foi inclusive objeto de uma revisão extraordinária que culminou com a introdução do novo artigo $295{ }^{\circ}$, que prevê a convocação de referendos sobre a aprovação de tratados que visem a construção e o aprofundamento da UE. Todavia, a não aprovação da Constituição Europeia devido às rejeições referendárias francesa e holandesa encarregar-se-ia de refrear os ímpetos dos governantes dos Estados membros relativamente à utilização daquela via de ratificação de tratados internacionais. Prova disso foi a prevalência da forma parlamentar no processo de ratificação do Tratado de Lisboa (com exceção da Irlanda, cuja Constituição obriga à convocação do referendo para aprovação de tratados europeus). Paulo de PITTA E CUNHA, O Tratado de Lisboa. Génese, conteúdo e efeitos, Lisboa, 2008 , p. 41, rotula todo este processo de volte-face relativamente à via ratificativa do Tratado de Lisboa de "habilidade", destacando ainda a passagem de um "atestado de menoridade política passado aos cidadãos" pelos Estados membros, maxime naqueles onde já se realizaram referendos a tratados europeus. Muito embora exista idêntica legitimidade democrática nas duas formas de ratificação, tal alteração inculca duas constatações: o receio dos governantes dos Estados relativamente à incerteza dos mecanismos de aprovação dos Tratados que passem pela consulta dos respetivos povos; por outro lado, indiretamente, está ainda muito longínqua a figura jurídica do referendo europeu e, com ele, um passo decisivo para a implementação de um dos principais mecanismos de democracia participativa no seio da UE. 
considerem necessária a adoção dos $\operatorname{mesmos}^{67}$. Exige-se a participação de, pelo menos, um milhão de peticionantes, os quais devem ser cidadãos da UE e nacionais de um número significativo de Estados membros. Trata-se de um número elevado que poderá contribuir para que este mecanismo dificilmente venha a ser despoletado, o que contribui para uma rígida regulação da participação dos cidadãos no domínio político enquanto prática social setorial e especializada ${ }^{68}$, a que acresce uma potencial limitação à capacidade emancipatória do ideal democrático no seio da $U E^{69}$. Não se trata ainda de atribuir aos cidadãos europeus o direito, partilhado com a Comissão, de iniciativa legislativa. Todavia, um primeiro passo nesse sentido poderá ter sido dado. Encontramos aqui um mecanismo pioneiro que tem a dimensão participativa do princípio democrático no horizonte. Com ele também se vislumbra um novo dever em que as instituições europeias ficam investidas: recorrendo aos meios adequados, elas darão aos cidadãos e às associações representativas a possibilidade de expressarem e partilharem publicamente os seus pontos de vista sobre todos os domínios de ação da União (n. ${ }^{\circ} 1$ do artigo $11 .^{\circ}$ do TUE).

\section{Conclusão}

O respeito do princípio democrático é, desde logo, exigível aos Estados europeus que desejem aderir à UE; igualmente, eventuais violações do mesmo pelos Estados membros podem justificar a aplicação de sanções pela União. Contudo, não sendo a UE um Estado e inexistindo uma soberania popular europeia, o princípio democrático agiliza uma dialética relativamente ao funcionamento interno da própria União enquanto organização internacional e externo nas relações estabelecidas com os Estados membros e com os particulares (maxime cidadãos e empresas). O défice democrático denunciado recentemente pelo Presidente da Comissão Jean-Claude Juncker a propósito da intervenção da troika (composta pelo FMI, BCE e Comissão Europeia) em Portugal, na Grécia e na Irlanda, deve ser um exemplo a não repetir, principalmente numa altura em que a União se deve centrar em desafios que relancem o projeto europeu - assente na reconciliação, na democracia e nos direitos fundamentais - e não apenas nas políticas orçamentais dos Estados.

67 Cfr. FAUSTO DE QUADROS, Direito..., cit., p. 163; Jónatas MACHADO, Direito da União Europeia, Coimbra, 2010, p. 253.

68 Ver Boaventura de SOUSA SANTOS, op. cit., p. 105.

69 Na síntese de Paulo de PITTA E CUNHA, op. cit., p. 54, "o tão falado direito de iniciativa dos cidadãos na elaboração da legislação europeia decorre de preceitos de muito duvidoso alcance prático". 


\section{Principio de proporcionalidad y delitos de peligro abstracto ${ }^{1}$}

TERESA AGUADO-CORREA

taguado@us.es

GALILEU - REVISTA DE DIREITO E ECONOMIA · e-ISSN 2184-1845

Volume XX $\cdot 1^{\text {st }}$ July Julho $-31^{\text {TH }}$ December Dezembro $2019 \cdot$ pp. 101-150

DOI: http://doi.org/10.26619/2184-1845.XX.2.6

Submitted on October 15 th $2019 \cdot$ Accepted on November 15 $15^{\text {th }}, 2019$

Submetido em 15 de Outubro, 2019 - Aceite a 15 de Novembro, 2019

RESUMEN Se analiza la compatibilidad de los delitos de peligro abstracto con los principios que integran el principio de proporcionalidad en sentido amplio: principio de idoneidad, principio de necesidad y el principio de proporcionalidad en sentido estricto (proporcionalidad abstracta y concreta). También, y dada la dimensión constitucional que adquieren estos conflictos, nos ocupamos del eventual control que puede efectuar el Tribunal Constitucional, principalmente, frente a una desmesurada intervención penal cuando se trata de comportamientos que sólo implican un peligro abstracto para el bien jurídico.

PALABRAS CLAVE idoneidad, necesidad, proporcionalidad en sentido estricto, delitos de peligro abstracto, control de constitucionalidad.

ABSTRACT The compatibility of the crimes of abstract danger is analyzed with the principles that integrate the principle of proportionality in a broad sense: principle of adequacy, principle of necessity and the principle of proportionality in the strict sense (abstract and concrete proportionality). Also, and given the constitutional dimension that these conflicts acquire, we deal with the eventual control that the Constitutional Court can carry out, mainly, in the face of an excessive criminal intervention when it comes to behaviors that only imply an abstract danger for the legal interest protected.

\footnotetext{
1 Este trabajo está publicado bajo el título "El principio de proporcionalidad en derecho penal. Especial consideración de los delitos de peligro abstracto" en el libro El principio de proporcionalidad penal, Ad Hoc, Buenos Aires, 2014. Es un resumen de la postura sostenida en mi tesis doctoral "El principio de proporcionalidad en Derecho Penal. Especial consideración de los delitos de peligro abstracto", defendida en abril de 1998 en la Universidad de Sevilla, y publicada como monografía en el año 1999 bajo el título El principio de proporcionalidad en Derecho Penal. Una versión actualizada y ampliada ha sido publicada bajo el título El principio constitucional de proporcionalidad por la Editorial Jurídica Continental, San José, 2013, publicación conforme a la cual se realizarán las citas del presente trabajo.
} 
KEYWORDS Adequacy, necessity, proportionality in a strict sense, abstract danger crime, constitutionality control.

\section{Introducción}

Ningún principio constitucional de los que afectan al sistema penal ha sufrido un auge tan extraordinario a nivel internacional en los últimos años como el principio constitucional de proporcionalidad. Los principales artífices de este apogeo han sido los órganos garante de las respectivas Constituciones Políticas.

En este trabajo abordamos la compatibilidad de los delitos de peligro abstracto con el principio de proporcionalidad en sentido amplio. Los que fueron denominados «hijastros de la dogmática penal» dejaron de serlo. El debate que la categoría de los delitos de peligro, y más concretamente la de los delitos de peligro abstracto, suscitó fundamentalmente en los años 80 y principios de los 90 del siglo pasado, aun cuando ya con anterioridad fueron objeto de una viva polémica, no se puede considerar aún concluido.

Si tradicionalmente se le ha prestado atención a la compatibilidad de los delitos de peligro abstracto con el principio de ofensividad, desde nuestro punto de vista no se acaban aquí los problemas de relevancia constitucional que plantea esta discutida categoría de delitos. Estos delitos presentan además problemas constitucionales puestos en relación con el resto de los subprincipios que conforman el principio de proporcionalidad en sentido amplio: principio de idoneidad, principio de intervención mínima y el principio de proporcionalidad en sentido estricto. También, y dada la dimensión constitucional que adquieren estos conflictos, hemos analizado el eventual control que puede efectuar el Tribunal Constitucional, principalmente, frente a una desmesurada intervención penal cuando se trata de comportamientos que sólo implican un peligro abstracto para el bien jurídico.

Este enfoque constitucional nos exige abordar previamente, y de forma sucinta en este trabajo, algunas cuestiones previas: la relación entre la Constitución y el Derecho penal²; consagración constitucional del principio de proporcionalidad 3 ; y el análisis del contenido del denominado principio de proporcionalidad en sentido amplio en Derecho penal ${ }^{4}$, teniendo muy presente en dicha labor la jurisprudencia del Tribunal Constitucional español.

2 Sobre esta relación, vid. AGUADO CORREA, El principio constitucional..., cit., pp. 29-46.

3 Vid. AGUADO CORREA, El principio constitucional..., cit., pp. 99-113.

4 El contenido de este principio en Derecho penal se analiza profusamente en AGUADO CORREA, El principio constitucional..., cit., pp. 123-267. 


\section{Constitución y derecho penal}

La relación existente entre la Constitución y el Derecho penal es innegable. La Constitución es expresión de los principios fundamentales que inspiran un Ordenamiento jurídico. En la base de todo texto constitucional, se encuentra latente una concepción del Derecho que informa todas las normas que componen el sistema jurídico, pudiéndose afirmar que el Derecho penal es la rama del Ordenamiento jurídico que se encuentra más ligada a la Constitución ${ }^{5}$, lo cual no es de extrañar si tenemos en cuenta que es la que en mayor medida afecta al individuo. Al ser la pena la principal consecuencia del delito, la relación entre la Constitución y el Derecho penal se acrecienta en la medida en que constituye el último recurso del poder del Estado y, por ello, se contempla generalmente en los textos constitucionales, desprendiéndose de dicha regulación consecuencias en lo que se refiere a su concepto, finalidad ${ }^{6}$.

Uno de los ámbitos en los que mejor puede apreciarse la relevancia de la Constitución para el Derecho penal es el de los límites al ius puniendi’: si queremos establecer límites al mismo éstos deberán derivarse del ordenamiento constitucional ${ }^{8}$. La formulación de un Código Penal que se adapte a los valores básicos de la convivencia debe empezar por el establecimiento de un sistema de garantías, de tal forma que el encabezamiento del Derecho penal se inicie por la fijación de sus límites9. Y es que la evolución histórica del Derecho penal no se identifica con su desaparición y sustitución por otros sistemas de control social más idóneos, sino que, por el contrario, se caracteriza por su paulatina racionalización y sometimiento a límites ${ }^{10}$. Como afirma HASSEMER, para el Derecho penal futuro se trata de hacer viable la orientación hacia el mantenimiento de los principios garantistas, no sólo para el «sistema» y el «Estado de Derecho», sino sobre todo para las personas que viven en el sistema ${ }^{11}$.

5 CARBONELL MATEU, Derecho penal: concepto y principios constitucionales, 2. ${ }^{\text {a }}$ ed., Valencia, 1996, pp. 79 y ss., para quien la función del Derecho penal es la tutela de «valores o intereses con relevancia constitucional», con lo que la Constitución delimitaría no sólo de forma positiva el campo de actuación del Derecho penal, sino que, por otra parte, viene a fundamentar y limitar la actuación de los poderes públicos.

6 COBO DEL ROSAL/VIVES ANTÓN, Derecho penal. Parte General, 4. ${ }^{\text {a }}$ ed., Valencia, 1996, p. 45.

7 CUELLO CONTRERAS, Derecho penal español. Curso de iniciación. Parte General. Nociones introductorias. Teoría del delito/1, Madrid, 1996, p. 54; ARROYO ZAPATERO, «Derecho penal económico y Constitución», RP, núm. 1, julio 1997, p. 1.

8 En este sentido ÁLVAREZ GARCÍA, «Bien jurídico y Constitución», CPC, 1991, p. 18.

9 Vid., en este sentido, CÓRDOBA RODA, «Nuevas formas de delito y principio de intervención mínima», La Ley, 1996, p. 1333.

10 MORALES PRATS en QUINTERO OLIVARES, Curso de Derecho penal. Parte General, Barcelona, 1996, p. 93. Vid., también en este sentido, GARCÍA-PABLOS, Derecho penal. Introducción, Madrid, 1995, p. 58; TERRADILLOS BASOCO, en MAPELLI CAFFARENA/TERRADILLOS BASOCO, Las consecuencias jurídicas del delito, $3 .^{\text {a }}$ ed., Madrid, 1996, p. 19.

11 HASSEMER, «Perspectivas del Derecho penal futuro», traducción de ANARTE BORRALLO, RP, núm. 1 (1997), p. 39 . 
Principio de proporcionalidad y delitos de peligro abstracto

TERESA AGUADO-CORREA

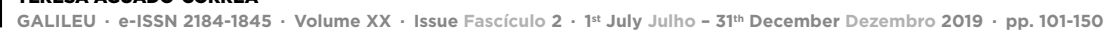




\section{Principio de proporcionalidad. Aspectos generales}

Aun cuando su origen se remonta a la Antigüedad, el principio de proporcionalidad sólo se pudo afirmar en la época de la Ilustración, cuando maduraron el resto de los demás presupuestos del Derecho penal moderno, es decir, la legalidad, la certeza, la igualdad y, especialmente, la calculabilidad y mensurabilidad de las penas ${ }^{12}$. BECCARIA, máximo representante del pensamiento ilustrado en el ámbito penal, concluyó su obra Dei delitti e delle pene afirmando: «De cuanto hasta aquí se ha dicho puede sacarse un teorema general, muy útil, pero poco conforme al uso, Legislador ordinario de las Naciones; esto es: para que la pena no sea violencia de uno o de muchos contra un particular ciudadano debe ser la pena pública, pronta, necesaria, la menor de las posibles en las circunstancias actuales, proporcionada a los delitos y dictada por las leyes» ${ }^{13}$. En el artículo 8 de la Declaración de Derechos del Hombre (1789) se decía: «La Loi ne doit établir que des peies strictement et évidemment nécessaires». El principio de proporcionalidad debe, en gran medida, su formulación actual al Tribunal Constitucional alemán (BVerfG). En los últimos años también ha sufrido un importante desarrollo, siguiendo la formulación del Tribunal Constitucional alemán, en la jurisprudencia constitucional de algunos países de Latinoamérica, como el Perú ${ }^{14}$, Colombia ${ }^{15}$, Brasil ${ }^{16}$ o Costa Rica ${ }^{17}$.

\section{Principio de proporcionalidad en sentido amplio en derecho penal}

\section{IV.1. Introducción}

En un Derecho de la intervención como lo es el Derecho penal, las garantías del Estado de Derecho han desempeñado la función de condicionar las intromisiones y su intensidad a determinados presupuestos, así como la función de minimizar-

12 FERRAJOLI, Derecho y razón. Teoría del garantismo penal, Madrid, 1995, p. 398. Nos recuerda FERRAJOLI, nota final 150, p. 451, que la exigencia de que la pena sea proporcionada a la gravedad del delito la podemos encontrar expresada en la obra de PLATÓN, Las leyes, cuando afirma: «¿No hemos de distinguir entre el ladrón que roba mucho o poco, el que roba de lugares sagrados o profanos, ni atenderemos a tantas otras circunstancias enteramente desemejantes entre sí, como se dan en el robo, que siendo muy variadas exigen que el legislador se atenga a ellas imponiendo castigos totalmente diferentes?». En la Carta Magna de 1215 también podemos encontrar sancionado el principio de proporcionalidad, al hablar en los apartados 20 y 21 de «proporción» entre pena y transgresión. En la época intermedia es reformulado por D’Isernia en los siguientes términos: «poena debet proportionari delicto».

13 BECCARIA, Tratado de los delitos y de las penas, traducción de JUAN ANTONIO DE LAS CASAS, edición de 1774, presentación de TOMÁS Y VALIENTE, Madrid, 1993, p. 255.

14 Cfr. AGUADO CORREA, El principio constitucional..., cit., pp. 472 y ss.

15 Vid., entre otras, Sentencias C-070 de 1996; C-939 de 2002; C-121 de 2012; C-212 de 2012; C 365 de 2012.

16 Vid, por todas, Habeas Corpus 104.410, Rio Grande do Sul, Ministro Gilmar Mendes, de 6 de marzo de 2012.

17 Cfr. AGUADO CORREA, El principio constitucional..., cit., pp. 404 y ss. 
las y controlarlas. Y en este contexto, se puede afirmar que el principio central es el de la proporcionalidad de las intervenciones, que deben ser necesarias y adecuadas para lograr su objetivo y también deben ser razonables o proporcionadas en cada caso $^{18}$. En el ámbito del Derecho penal, sin embargo, el principio de proporcionalidad en sentido amplio tiene un significado mucho más restringido pero no por ello menos importante que en el ámbito procesal penal o en el derecho administrativo, por diversos motivos. En primer lugar, porque de la relación de las normas penales se puede deducir que el fin que a través de las mismas se persigue es único: protección de los bienes jurídicos frente a lesiones o puestas en peligro, a través de la amenaza penal. En segundo lugar, porque este fin será alcanzado a través del medio de la desaprobación ético-social del comportamiento delictivo $^{19}$. Así lo ha puesto de manifiesto el Tribunal Constitucional alemán, al afirmar que el principio de proporcionalidad adquiere un papel relevante cuando se trata de examinar un precepto penal, puesto que la mayor sanción de la que dispone el Estado es el reproche ético-social sobre un determinado comportamiento del ciudadano [BVerfGE 90, 145 (172)]. Siendo el fin del Derecho penal la protección de bienes jurídicos ${ }^{20}$, lo cual limita la amenaza penal a aquellos comportamientos que pongan en peligro o lesionen el bien jurídico, también se introduce una limitación al medio que pueda utilizar el legislador para alcanzar dicho fin. Tanto las normas redactadas por el legislador como las sanciones que en el caso concreto sean impuestas por el juez - penas, medidas de seguridad o consecuencias accesorias - han de resultar medios adecuados para luchar contra los delitos ${ }^{21}$.

Nos encontramos ante un principio que opera tanto en el momento de creación del Derecho por los legisladores como en el de su aplicación por los Jueces o Tribunales e incluso en el momento de ejecución de la pena, medida de seguridad o consecuencia accesoria. En el ámbito del Derecho penal se destaca la funcionalidad de este principio en la tipicidad, la antijuricidad y en el establecimiento del enlace material entre el delito y su consecuencia jurídica $^{22}$. En primer lugar, la prohibición de exceso actuaría como límite a la criminalización de conductas que el legislador lleva a cabo a través de la creación de tipos

18 HASSEMER, «Perspectivas del Derecho penal futuro», RP, núm. 1 (1997), p. 39.

19 TIEDEMANN, Tatbestandsfunktionen im Nebenstrafrecht. Untersuchungen zu einem rechtsstaatlichen Tatbestandsbegriff, entwickelt am Problem des Wirtschaftsstrafrechts, Tübingen, 1969, p. 144; el mismo, en «Grundgesetz und Strafrecht»,40 Jahre Grundgesetz. Der Einfluß des Verfassungsrechts auf die Entwicklung der Rechtsordnung, Heidelberg, 1990, p. 172.

20 Adoptamos de esta manera la postura que sostiene tanto la doctrina mayoritaria como el Tribunal Constitucional, en torno a la función del Derecho penal.

21 RUDOLPHI, Systematischer Kommentar zum Strafgesetzbuch, I 13 Lfg. 5 Auf. (November 1990), previo al § 1, Nm. 12, expresa esta idea con la siguiente afirmación: «A la exactitud y razonabilidad del fin se le debe añadir la exactitud y razonabilidad del medio».

22 Cfr. SÁNCHEZ GARCÍA, «El principio constitucional de proporcionalidad en Derecho penal», La Ley, 1994, p. 1118. 
penales $^{23}$, como tendremos ocasión de comprobar a lo largo de este trabajo. En segundo lugar, una vez afirmada la tipicidad de un comportamiento, en el ámbito de la antijuricidad hay que comprobar la ausencia de causas de justificación, campo en el juegan un papel fundamental los principios de necesidad y proporcionalidad ${ }^{24}$ como criterios de ponderación de intereses ${ }^{25}$, sin que quepa olvidar el principio de idoneidad ${ }^{26}$. En último lugar, hay que acudir al principio de proporcionalidad en sentido amplio para entender el enlace material entre el delito y su consecuencia jurídica ${ }^{27}$. Al poseer rango constitucional, en Derecho penal no puede exigirse su respeto exclusivamente en el ámbito de las penas sino también en el ámbito del resto de las consecuencias jurídico-penales que se pueden derivar de la comisión de un delito: las medidas de seguridad y las consecuencias accesorias. Incluso se puede afirmar que la relevancia del principio de proporcionalidad es mayor en el ámbito de las medidas de seguridad que en el ámbito de las penas ${ }^{28}$.

\section{IV.2. Consagración constitucional}

Aun cuando la mayoría de la doctrina española se muestra de acuerdo en reconocer rango constitucional al principio de proporcionalidad, no existe consenso sobre el precepto o preceptos constitucionales donde pueda considerarse consagrado, pudiéndose constatar una gran diversidad de opiniones doctrinales ${ }^{29}$. En nuestra opinión, el principio de proporcionalidad es un principio constitucional que cabe inferir de los artículos 1.1, 9.3 y 10.1 CE. No se trata, como ocurre con el principio de legalidad, de un principio contemplado como un derecho fundamental ${ }^{30}$, sino, tal y como ha expresado el Tribunal Constitucional (SSTC 55/1996 y 161/1997), un principio reconocido implícitamente en tres preceptos consti-

23 SÁNCHEZ GARCÍA, «El principio constitucional...», La Ley, 1994, pp. 1118 y 1119.

24 Cfr. AGUADO CORREA, El principio constitucional..., cit., p. 96.

25 Cfr. SÁNCHEZ GARCÍA, «El principio constitucional...», La Ley, 1994, pp. 1120 y ss.; en el seno de la doctrina alemana, RUDOLPHI, «Rechtsfertigungsgründe im Strafrecht. Ein Beitrag zur Funktion. Struktur und den Prinzipien», Gedächtnisschrift für Armin Kaufmann, Köln, 1989, pp. 389 y ss.

26 Aun cuando este principio no es destacado por los autores, es un principio del cual no se puede prescindir en algunas causas de justificación. Cfr. GÜNTHER, Strafrechtswidrigkeit und Strafrechtsausschluß..., cit., 179; más referencias doctrinales en AGUADO CORREA, El principio constitucional..., cit., pp. 95 y ss.

27 SÁNCHEZ GARCÍA, «El principio constitucional...», La Ley, 1994, p. 1122.

28 Cfr. AGUADO CORREA, El principio constitucional..., cit., pp. 97 y ss.

29 Sobre la diversidad de opiniones doctrinales vid. AGUADO CORREA, El principio constitucional..., cit., pp. 99 y ss.

30 No obstante, el Tribunal Constitucional español, apartándose de sus pronunciamientos anteriores (SSTC 55/1996 y 161/1997 y la jurisprudencia allí citada), en la controvertida Sentencia 136/1999, consideró que el principio de proporcionalidad en sentido amplio se encontraba consagrado en el art. 25.1 CE, precepto en el que contempla el principio de legalidad. A la vista de los citados antecedentes jurisprudenciales, resulta sorprendente que el Tribunal Constitucional declarase en esta Sentencia 136/1999 la inconstitucionalidad del art. 174 bis a) CP, por vulneración del derecho a la legalidad penal (art. 25.1 CE) desde la perspectiva del principio de proporcionalidad, en los siguientes términos: «se ha producido una vulneración del principio de legalidad penal en cuanto comprensivo de la proscripción constitucional de penas desproporcionadas» FJ (30). Cfr. AGUADO CORREA, El principio constitucional..., cit., p. 392. 
tucionales de gran relevancia como son aquel en el que se afirma que España se constituye en un Estado social y democrático de Derecho y propugna como valores superiores de su ordenamiento la justicia y la libertad (art. 1.1 CE); el artículo 9.3 CE, en el cual se contempla el principio de prohibición de arbitrariedad de los poderes públicos, $y$, finalmente, el principio de proporcionalidad se puede inferir de la dignidad de la persona proclamada en el artículo 10.1 $\mathrm{CE}^{31}$.

El principal ámbito de aplicación del principio de constitucionalidad es el de los derechos fundamentales ${ }^{32}$, por lo que no será difícil que en el ámbito de Derecho penal la falta de proporción implique un sacrificio innecesario o excesivo del derecho a la libertad reconocido en el artículo $17 \mathrm{CE}$, puesto que toda norma penal conlleva una restricción de la libertad individual (STC 105/1988) ${ }^{33}$, con la consiguiente posibilidad de interponer un recurso de amparo $^{34}$.

\section{IV.3. Contenido del principio de proporcionalidad}

La discrepancia en torno al principio de proporcionalidad no se agota en la determinación de los preceptos constitucionales en los cuales se puede considerar consagrado este principio, sino que también se extiende al posible contenido ${ }^{35}$.

Desde nuestro punto de vista, se puede hablar de un principio de proporcionalidad en sentido amplio que se descompone en tres subprincipios o, en la terminología del Tribunal Constitucional ${ }^{36}$, hablar de un principio cuya aplicación es regida por

31 La importancia de estos tres artículos es tal que GARRIDO FALLA, Comentarios a la Constitución española, 2. ${ }^{\mathrm{a}}$ ed., Madrid, 1985, p. 186, ha afirmado que conforman «la trilogía de los que realizan la positivización de principios generales que constituyen una de las características de la Constitución». Cfr. AGUADO CORREA, El principio constitucional..., cit., p. 111 y ss.

32 Aun cuando el Tribunal Constitucional, español reconoce que el ámbito propio de aplicación del principio de proporcionalidad es el de los derechos fundamentales, no llega hasta el punto de derivar el principio de proporcionalidad de los derechos fundamentales, tal y como ha hecho el BVerfG.

33 En la BVerfGE 90, 145 (172), el Tribunal Constitucional alemán ha puesto de relieve que para determinar la proporcionalidad de toda norma penal, la sanción penal con la que se amenaza ha de ser analizada en relación con el artículo 2.2.2 GG, en el cual ser reconoce la inviolabilidad del derecho a la libertad. Vid. LAGODNY, Strafrecht vor den Schranken der Grundrechte. Die Ermächtigung zum strafrechtlichen Vorwurf im Lichte der Grundrechtsdogmatik dargestellt am Beispiel der Vorfeldkriminalisierung, Tübingen, 1996 p. 130.

34 Esta posibilidad ha sido avalada por lo afirmado por el Alto Tribunal en la Sentencia de 2 de octubre de 1997 (STC 161/1997 FFJJ 8 y 9).

35 Sobre la polémica doctrinal vid. AGUADO CORREA, El principio constitucional..., cit., pp. 114 y ss.

36 La STC 66/1995, de 8 de mayo, es la primera resolución en la que el Tribunal Constitucional español habla expresamente de la idoneidad, necesariedad y proporcionalidad como requisitos o condiciones necesarios para superar el juicio de proporcionalidad, si bien es en el Fundamento Jurídico 6 de la Sentencia 55/1996, donde el Tribunal Constitucional reconoce la descomposición del principio de proporcionalidad en tres subprincipios, tal y como ya venía ocurriendo en la jurisprudencia del BVerfG desde hacía años, así como en una parte minoritaria de la doctrina penal española. Sobre la doctrina jurisprudencial del TC vid. AGUADO CORREA, El principio constitucional..., cit., p. 115 y ss. 
tres condiciones: idoneidad, necesidad y proporcionalidad en sentido estricto. Tal y como ha concretado el Tribunal Constitucional estas condiciones, cabe decir que en virtud del primer subprincipio, la medida ha de ser apta para alcanzar el fin pretendido. La necesidad de la medida implica que no se podía optar por otra igualmente eficaz, que no gravase o lo hiciese en menor medida los derechos afectados. En último lugar, el sacrificio que se impone al derecho correspondiente debe guardar un razonable equilibrio o proporción con los bienes jurídicos que se pretenden salvaguardar.

Los tres subprincipios en los que cabe descomponer el principio de proporcionalidad en sentido amplio, los concretaremos en el ámbito del Derecho penal de la siguiente forma. En primer lugar, el principio de idoneidad requiere que el Derecho penal sea apto para la tutela del bien jurídico y que la medida adoptada sea adecuada para conseguir la finalidad que se persigue. El principio de necesidad en Derecho penal se concreta, por una parte, en el principio de exclusiva protección de bienes jurídicos y, por otra, en el principio de intervención mínima con los dos postulados que lo integran: ultima ratio y carácter fragmentario del Derecho penal. El principio de proporcionalidad en sentido estricto viene a coincidir con el principio de proporcionalidad de las penas tal y como ha sido entendido tradicionalmente por la doctrina.

\section{IV.3.A. Principio de idoneidad}

\section{Formulación}

El nacimiento del denominado principio de idoneidad, eficacia o utilidad ${ }^{37}$ se sitúa en von Liszt $^{38}$, apareciendo posteriormente reflejado también en la obra de MAYER ${ }^{39}$ cuando al establecer los criterios de intervención penal, exigía que el bien jurídico reuniese tres cualidades: «merecedor de protección», estar «necesitado de protección» y ser «capaz de protección ${ }^{40}$. Es a partir de esta capacidad de protección cuando se puede hablar de idoneidad o inidoneidad del Derecho penal, capacidad que habrá que valorar teniendo en cuenta todas

37 MIR PUIG, Derecho penal. Parte General, $4 .^{\text {a }}$ ed., Barcelona, 1996, p. 88, habla del principio de utilidad de la intervención penal como principio limitador del ius puniendi propio de un Estado social. FERNÁNDEZ RODRÍGUEZ, «Los límites del ius puniendi», ADPCP, 1994, p. 101, se refiere a él como principio de oportunidad o de utilidad del Derecho.

38 VON LISZT, Lehrbuch des deutschen Strafrechts, 21. ${ }^{\mathrm{a}} / 22 .^{\mathrm{a}}$ ed., Berlín/Leipzig, 1919, pp. 6 y 21.

39 MAYER, M. E., Der Allgemeiner Teil des deutschen Strafrechts, 2. a ed., Heidelberg, 1923, 23

40 LUZÓN PEÑA, Curso de Derecho penal. Parte General I, Madrid, 1996, p. 84. SILVA SÁNCHEZ, Aproximación al Derecho penal contemporáneo, Barcelona, 1992, p. 289, estima que la «susceptibilidad» de protección penal puede entenderse incluida en la «necesidad», puesto que si el bien no es apto para la protección penal, es obvio que no necesita esa protección. 
las condiciones reales del sistema penal ${ }^{41}$. No todos los bienes jurídicos que reúnen las dos primeras cualidades son también aptos o idóneos para ser protegidos penalmente, ofreciéndose como ejemplo de estos bienes jurídicos la moral sexual. ${ }^{42}$. En virtud de este principio de idoneidad, el Derecho penal únicamente puede y debe intervenir cuando sea mínimamente eficaz e idóneo para prevenir el delito, debiéndose evitar su intervención cuando político-criminalmente éste se muestre inoperante, ineficaz o inadecuado o cuando incluso se muestre contraproducente para la prevención de delitos ${ }^{43}$.

Teniendo en cuenta el presupuesto de que el fin de las normas que prevén penas es la protección de bienes jurídicos a través de la prevención, tanto general como especial ${ }^{44}$, habrá que excluir del Derecho penal aquellas penas que se manifiesten como ineficaces por no servir a la prevención. Por otra parte, también pueden darse supuestos en los que una concreta tipificación del delito se muestra ineficaz, existiendo una elevada «cifra negra» de comisión de delitos ${ }^{45}$. El principio de idoneidad implica, además de la necesidad de que la pena sea apta para la tutela del bien jurídico - para evitar conductas que lo pongan en peligro o lo lesionen-, que la pena sea «cualitativamente adecuada para conseguir la finalidad». Ya en este sentido afirmaba BECCARIA: «Otro principio que sirve admirablemente para estrechar más y más la importante conexión entre el delito y la pena; este es, que se ella conforme, quanto se pueda, a la naturaleza del mismo delito» ${ }^{46}$.

No se agota aquí el significado del principio de idoneidad, sino que este principio también implica que el mismo ha de ser realizable a través de la normas de Derecho procesal ${ }^{47} \mathrm{y}$ de Derecho penitenciario ${ }^{48}$. De nada serviría una regulación penal si ésta no puede llevarse a la práctica ${ }^{49}$.

41 SILVA SÁNCHEZ, Aproximación al Derecho..., cit., p. 289.

42 MUÑOZ CONDE, en MUÑOZ CONDE/GARCÍA ARÁN, Derecho penal. Parte General, Valencia, 1996, p. 83.

43 GÜNTHER, Strafrechtswidrigkeit und Strafunrechtsausschluß..., cit., p. 186; LUZÓN PEÑA, Curso de Derecho..., cit., p. 84; FERNÁNDEZ RODRÍGUEZ, «Los límites del ius puniendi», ADPCP, 1994, p. 101.

44 Una vez negado que la retribución fuese el fin de las penas, afirma BECCARIA (Tratado de los delitos..., cit., p. 60): «El fin, pues, no es otro que impedir al reo causar nuevos daños a sus ciudadanos, y retraher los demás de la comisión de otros iguales.»

45 Como ejemplo se ofrece la regulación del aborto antes de que se introdujese el artículo 417 bis ACP - punible sin excepción alguna-, regulación que debido a que no era compartida por gran parte de la sociedad, carecía de eficacia preventivo-general.

46 BECCARIA, Tratado de los delitos..., cit., p. 108; CARBONELL MATEU, Derecho penal: concepto..., cit., p. 199.

47 ARMENTA DEU, «Pena y proceso: fines comunes y fines específicos», en Política criminal y nuevo Derecho penal. Libro homenaje a Claus Roxin, Barcelona, 1997, p. 215.

48 En este sentido, RUDOLPHI, Systemmatischer Kommentar, ,cit., previos al § 1, Nm. 13; HASSEMER, Theorie und soziologie des Verbrechens. Ansätze zu einer prazisorientierten Rechtsgutslehre, Frankfurt am Main, 1973, pp. 196 y ss.

49 No debemos olvidar que en el artículo 24.2 de la Constitución Española se reconoce el derecho fundamental a un proceso sin dilaciones indebidas. 


\section{Respeto del principio de idoneidad}

El debate sobre la idoneidad del Derecho penal adquirió un gran protagonismo en el seno de la doctrina alemana, debido al planteamiento realizado por la «Escuela de Frankfurt» sobre la inidoneidad del Derecho penal para hacer frente a los problemas que se derivan de lo que se denomina «sociedad de riesgo ${ }^{50}$. En este sentido, HASSEMER previene de los inconvenientes de lo que se entiende por un Derecho penal «eficaz»y, desde luego, no le falta razón. Ante el acuciante sentimiento que tiene la sociedad de amenaza por la creciente violencia que se da en el seno de la misma, se recurre al Derecho penal y al Derecho procesal penal, esperándose de los mismos una ayuda eficaz ante situaciones de necesidad y también que garanticen la seguridad de los ciudadanos ${ }^{51}$. Con ello se provoca una mayor dureza del Derecho penal y del Derecho procesal penal, puesto que se pretende afrontar de un modo efectivo el creciente sentimiento de inseguridad. Por una parte, la Política criminal «moderna» se caracteriza por la creación de nuevos delitos y agravación de las penas de los ya existentes; por otra parte, el Derecho penal amplía su ámbito de actuación a los sectores que la opinión pública considera más amenazados: el medio ambiente, la economía, las drogas, el terrorismo, la delincuencia organizada. Se trata de proteger bienes jurídicos colectivos que pueden, según este autor, justificar cualquier tipo de conminación penal y para cuya protección se utiliza normalmente la técnica del peligro abstracto. Esta Política Criminal desemboca en un debilitamiento de la vinculación del Derecho penal a los principios que lo limitan y se minimizan los presupuestos de la pena con el empleo de la técnica de los delitos de peligro abstracto. Ello hace olvidar al legislador que un Derecho penal contundente tiene sus costos «y se paga con la renuncia a principios políticamente valiosos y difíciles de mantener ${ }^{52}$. Al prescindir de principios tan importantes como el principio de proporcionalidad en sentido amplio, el principio de culpabilidad o el principio in dubio pro reo, el Derecho penal aumenta su eficacia y responde así a las inquietudes sociales ${ }^{53}$.

50 El primero en utilizar esta expresión fue el sociólogo alemán BECK en su monografía Risikogesellschaft. Auf dem Weg in eine andere Moderne, Frankfurt a. M., 1986. Esta expresión, que en palabras de KUHLEN, «Zum Strafrecht der Risikogesellschaft», GA, 1994, p. 347, «en los últimos años ha hecho furor», ha sido adoptada en el seno de la dogmática penal.

51 HASSEMER, «El destino de los derechos del ciudadano en un Derecho penal "eficaz"», EPC, XV (1990-1991), p. 189.

52 HASSEMER, «El destino de los derechos...», EPC, XV (1990-1991), p. 197.

53 PRITTWITZ, Strafrecht und Risiko. Untersuchungen zur Krise von Strafrecht und Kriminalpolitik in der Risikogesellschaft, Frankfurt am Main, 1993, p. 370, afirma que muestra de que el Derecho penal no constituye un medio idóneo para hacer frente a los problemas generados por la sociedad de riesgo, es que en ninguno de los campos nuevos de actuación del Derecho penal se pueden demostrar resultados visibles. 


\section{IV.3.B. Principio de necesidad en derecho penal}

\section{Introducción}

El Derecho penal es necesario cuando lo exige la protección de bienes jurídicos, si bien no todo bien jurídico ha de convertirse en un bien jurídico penal, al ser el concepto de bien jurídico más amplio que el de bien jurídico penal. Por otra parte, el Derecho penal no es necesario frente a todo ataque a bienes jurídicos penalmente tutelados, sino tan sólo frente a los ataques más graves. Ello nos lleva a afirmar que el principio de necesidad se concreta, en el ámbito del Derecho penal, en el principio de exclusiva protección de bienes jurídicos y en el principio de intervención mínima con las dos manifestaciones de este principio: el principio de subsidiariedad y el principio de fragmentariedad. Si bien el principio de necesidad adquiere especial relevancia en el momento legislativo, en el momento de selección de las conductas a incriminar, también opera en el momento de aplicación de la ley penal: tanto el hecho de recurrir a la amenaza a través de la conminación penal como en su caso la gravedad de la pena ha de justificarse en la necesidad de protección de bienes jurídicos.

\section{Principio de exclusiva protección de bienes jurídicos}

La mayoría de la doctrina admite como uno de los límites al ius puniendi el denominado principio de exclusiva protección de bienes jurídicos. En virtud del mismo, el Derecho penal tan sólo ha de intervenir cuando se trata de proteger bienes jurídicos (penales). Constituye una de las garantías del Derecho penal moderno ${ }^{54}$ que no sólo explica la función del Derecho penal (protección de bienes jurídicos) ${ }^{55}$, sino que limita y circunscribe la intervención punitiva del Estado ${ }^{56}$. Además, el Derecho penal no puede incriminar cualquier conducta, sino tan sólo aquellas que lesionen o pongan en peligro el bien jurídico, correspondiéndose de esta forma el principio de exclusiva protección de bienes jurídicos con el principio de ofensividad o lesividad ${ }^{57}$, el cual se usa para expresar el conocido aforismo

54 SILVA SÁNCHEZ, Aproximación al Derecho..., cit., p. 267. Si bien se trata de una garantía del Derecho penal moderno, no ha sido tan fácil su aceptación en los diversos ordenamientos.

55 El propio Tribunal Constitucional asigna en la STC 105/1988, de 8 de junio, esta función al Derecho penal al afirmar que «la restricción de la libertad individual que toda norma comporta» sólo puede tener lugar «con la finalidad de dotar de la necesaria protección a valores, bienes o intereses que sean constitucionalmente legítimos en un Estado social y democrático de Derecho».

56 GARCÍA-PABLOS, Derecho penal..., cit., p. 264.

57 En este sentido se pronuncian GARCÍA-PABLOS, Derecho penal..., cit., p. 264. Por su parte, COBO/VIVES, Derecho penal.., cit., p. 290, afirman que el principio de ofensión o «lesividad» ha de ser reconducido de forma inexorable al principio de legalidad, puesto que se encuentra limitado y condicionado por este principio. SILVA SÁNCHEZ, Aproximación al Derecho..., cit., p. 291, estima el principio de lesividad u ofensividad como parte integrante del principio de protección fragmentaria, en el cual inciden tanto consideraciones de proporcionalidad como consideraciones de utilidad. 
nullum crimen sine iniuria, es decir, que todo delito comporta la lesión o puesta en peligro de un bien jurídico ${ }^{58}$.El principio de exclusiva protección de bienes jurídicos permite, por lo tanto, la exclusión del ámbito del Derecho penal, por un lado, de las incriminaciones a través de las cuales se pretenden proteger meros valores éticos o morales ${ }^{59}$, sin que por ello se desconozca que los bienes jurídicos penales puedan ser también bienes morales, pero requieren algo más para merecer la protección por parte del Derecho penal ${ }^{60}$. Por otro lado, el principio de protección exclusiva de bienes jurídicos, y más concretamente el principio de ofensividad, permite excluir aquellas acciones que en concreto se muestran inofensivas para el bien jurídico protegido ${ }^{61}$.

El carácter de límite al ius puniendi que venimos propugnando de este principio, se ha visto enturbiado en buena parte por la polémica suscitada, y aún no zanjada, en torno al concepto de bien jurídico. La capacidad o incapacidad del concepto de bien jurídico para servir de límite al ius puniendi depende del criterio por el que se opte para la selección de los bienes protegibles penalmente ${ }^{62}$, convirtiéndose así la discusión sobre el bien jurídico en «primordial cuestión político-criminal» ${ }^{63}$. Para algún autor, incluso el problema de selección de bienes jurídicos a proteger se convertiría en el problema central del Derecho penal $^{64}$. Son dos las corrientes principales que tienden a dotar de un contenido material al concepto de bien jurídico para que pueda ejercer la función de límite del ius puniendi, sin que ninguna de ellas esté libre de toda objeción: por una parte, nos encontramos con las teorías sociológico-funcionalistas y, por otra, con las teorías constitucionalistas.

También hay algunos autores que ante la dificultad de establecer positivamente qué ha de ser protegido penalmente, se inclinan por determinar qué ha de ser protegido penalmente a través de un proceso de carácter negativo, es decir, establecer un método a través del cual se determinen aquellos bienes jurídicos que no son merecedores de tutela penal. Antes que ofrecer un concepto abstracto de bien jurídico, que plantee los problemas que

58 No hay que entender esta puesta en peligro como la exigencia de un peligro concreto, cfr. AGUADO CORREA, El principio constitucional..., cit., p. 132, n.p.p. 42.

59 COBO/VIVES, Derecho penal..., cit., p. 290; GARCÍA-PABLOS, Derecho penal..., cit., p. 265.

60 MIR PUIG, Derecho penal..., cit., p. 91. ROXIN, Strafrecht. Allgemeiner Teil, cit., § 2/12, afirma que la exclusión de las contravenciones morales del Derecho penal no significa que también algunos «sentimientos» (Empfindungen) deban ser protegidos penalmente.

61 Haremos referencia al principio de exclusiva protección de bienes jurídicos cuando se trate de imponer un límite al legislador y hablaremos de principio de ofensividad cuando hagamos referencia al límite a la actividad de interpretación y aplicación de las leyes por parte del poder judicial.

62 Así lo ha puesto de manifiesto expresamente en nuestra doctrina, entre otros, GÓMEZ BENÍTEZ, «Sobre la teoría del "bien jurídico" (aproximación al ilícito)», RFDUCM, 69 (1983), p. 87.

63 QUINTERO OLIVARES, Curso de Derecho penal..., cit., p. 244. También MUÑOZ CONDE, en MUÑOZ CONDE/ GARCÍA ARÁN, Derecho penal..., cit., p. 81, considera que la protección de bienes jurídicos a través del Derecho penal constituye un problema de Política Criminal antes que una cuestión dogmática.

64 MORALES PRATS, en QUINTERO OLIVARES, Curso de Derecho penal..., cit., p. 91. 
se vienen exponiendo para ejercer la función de garantía o límite al ius puniendi, prefieren ofrecer criterios delimitadores hablando de un Derecho penal mínimo ${ }^{65}$.

Para que el bien jurídico pueda desempeñar esta función y no únicamente una función interpretativa o sistemática, es imprescindible distinguir entre «bien jurídico» y ratio legis, puesto que si confundimos ambos conceptos, el bien jurídico perdería su utilidad como criterio limitador, como se puso de manifiesto con la propuesta realizada por HONIG ${ }^{66}$. La finalidad objetiva de la norma no tiene por qué coincidir con el bien jurídico protegido por la norma ${ }^{67}$. Además, la finalidad puede alcanzarse o no, pero el bien jurídico siempre ha de resultar lesionado o puesto en peligro ${ }^{68}$.

Por lo que respecta a la doctrina jurisprudencial del TC sobre los criterios de selección de los bienes jurídico-penales. En este sentido adquiere especial relevancia el pronunciamiento contenido en el Fundamento Jurídico 6 de la Sentencia del Tribunal Constitucional, de 28 de marzo (STC 55/1996): «La respuesta a esta cuestión debe partir inexcusablemente del recuerdo de la potestad exclusiva del legislador para configurar los bienes penalmente protegidos...En el ejercicio de su competencia de selección de los bienes jurídicos que dimanan de un determinado modelo de convivencia social y de los comportamientos atentatorios contra ellos, así como la determinación de las sanciones penales necesarias para la preservación del referido modelo, el legislador goza, dentro de los límites establecidos

65 En la obra de FERRAJOLI, Derecho y razón... cit., p. 479, encontramos expresadas estas ideas, incluso con cierta contundencia. Según este autor, todos los delitos de peligro abstracto o delitos de peligro presunto deberían ser reestructurados sobre la base del principio de lesividad, como delitos de lesión o al menos de peligro concreto. En este sentido, las propuestas de PORTILLA CONTRERAS, «Principio de intervención mínima y bienes jurídicos colectivos», CPC, núm. 39 (1989); ZUGALDÍA ESPINAR, Fundamentos de Derecho penal, 3. ${ }^{a}$ ed., Valencia, 1993, pp. 52 y ss.

66 Este autor alemán, en su obra Die Einwilligung des Verletzten. Die Geschichte des Einwilligungsproblems und die Methodenfrage, 1919, p. 94, citado por RUDOLPHI, «Los diferentes aspectos del concepto de bien jurídico», Nuevo Pensamiento Penal, 1975, pp. 331 y 332, concibió el bien jurídico protegido como «el fin que ha reconocido el legislador en las prescripciones penales, en su más breve formulación».

67 Por ello resulta criticable, desde nuestro punto de vista, el pronunciamiento del Tribunal Constitucional en la Sentencia 55/1996, en la que da primacía a la finalidad, sin que le importe el bien jurídico protegido por la norma, en estos términos: «Con independencia de cuál sea el bien jurídico protegido por la norma analizada (LO 8/1984), lo cierto es que la finalidad de protección explícita e inmediata de la misma recae sobre...». Afortunadamente, el Tribunal Constitucional ha rectificado esta postura en la STC 161/1997, al afirmar: «conviene precisar como prius lógico de este enjuiciamiento los bienes o intereses que la norma cuestionada pretende proteger» (FJ 10).

68 Cuando COBO/VIVES, Derecho penal..., cit., p. 295, estudian la función exegética del bien jurídico, destacan la insuficiencia del mismo como criterio rector de la interpretación, proponiendo acudir a otros criterios. Entre estos criterios incluyen la ratio legis, puesto que no siempre se trata de un criterio idéntico al del bien jurídico: no siempre la protección penal otorgada a un determinado bien jurídico constituye la finalidad última perseguida por el legislador cuando decide incriminar determinados comportamientos. Estos autores nos recuerdan que, en ocasiones, se protege un bien jurídico para obtener determinados resultados «más o menos conectados remotamente con él». De ello derivan que incluso admitiendo que la ratio legis cumpla un papel en la interpretación de los tipos, es de carácter subsidiario porque a lo que hay que atender es al tipo de injusto, el cual consiste en la lesión o puesta en peligro del bien jurídicamente protegido. 
en la Constitución, de un amplio margen de libertad, margen de libertad que deriva de su posición constitucional y, en última instancia, de su específica legitimidad democrática. No sólo cabe afirmar, pues, que, como no puede ser de otro modo en un Estado social y democrático de Derecho, corresponde en exclusiva al legislador el diseño de la política criminal, sino también que, con la excepción que imponen las citadas pautas elementales que emanan del texto constitucional, dispone para ello de plena libertad.»

Pero el Tribunal Constitucional realiza otra afirmación en esta Sentencia (55/1996) que puede resultar de interés para concretar estas pautas elementales que ha de tener en cuenta el legislador, y más aún si tenemos en cuenta que ha vuelto a pronunciarse en términos muy parecidos en la Sentencia 161/1997 (FJ 10): «... debemos precisar en primer lugar cuál es el bien jurídico protegido por la norma cuestionada o, mejor, cuáles son los fines inmediatos y mediatos de protección de la misma. Esta premisa constituye un prius lógico para la determinación de si el legislador ha incurrido en el exceso manifiesto en el rigor de las penas vulnerador del artículo 17.1 CE, al introducir un sacrificio patentemente inidóneo, innecesario o desproporcionado del derecho a la libertad; a la par que permite descartar toda posibilidad de sujeción mínima al principio de proporcionalidad si el sacrificio de la libertad que impone la norma persigue la preservación de bienes o intereses, no sólo, por supuesto, constitucionalmente proscritos, sino ya también, socialmente irrelevantes (STC 111/1993)».

En vista de la doctrina del Tribunal Constitucional acerca del principio de exclusiva protección de bienes jurídicos, cabe concluir que carecen de toda justificación aquellas posturas que niegan cualquier valor o referencia al marco ofrecido por la Constitución. El legislador, como ha reconocido el Tribunal Constitucional, posee plena libertad para el diseño de la política criminal y la selección de bienes jurídicos, pero ha de proceder dentro de los límites establecidos por la Constitución. Por ello, y dada la restricción de libertad que comporta toda norma penal, únicamente podrá proteger penalmente valores, bienes o intereses constitucionalmente legítimos y socialmente relevantes. Este límite - constitucionalmente legítimo e importancia social - no será difícil de superar por el legislador y poco tendrá que decir al respecto el máximo órgano garante de la Constitución. Aparece, pues, el principio de protección exclusiva de bienes jurídicos como un límite «relativo» en la elección de los bienes jurídicos a tutelar ${ }^{69}$. Ni incluso la relevancia constitucional de un determinado bien jurídico aparece como un verdadero límite al ius puniendi. Un ejemplo lo encontramos en el campo del Derecho penal económico ${ }^{70}$.

69 En este sentido DOLCINI/MARINUCCI, «Costituzione e politica dei beni giuridici», RIDPP, 1994, pp. 334 y 335. 70 Vid. ARROYO ZAPATERO, «Derecho penal económico y Constitución», RP, 1997, pp. 3 y 4. Cfr. ulteriores referencias en AGUADO CORREA, El principio constitucional..., cit., pp. 161 y ss. 
Como hemos señalado anteriormente, el principio de exclusiva protección de bienes jurídicos se corresponde con el principio de ofensividad en el sentido de que todo delito ha de comportar la lesión o puesta en peligro de un bien jurídico, exigiendo en el momento de aplicación de la ley penal que el comportamiento concreto que se está juzgando haya lesionado o puesto en peligro el bien jurídico. En este sentido se habla de una «doble influencia» del principio de lesividad ${ }^{71}$ : por una parte, sobre el legislador, que es el que elige el bien jurídico a tutelar; por otra parte, sobre el juez, quien no se puede conformar con la subsunción formal del hecho en el comportamiento descrito por la norma, sino que tendrá que comprobar que dicho comportamiento ha lesionado o ha puesto en peligro el bien jurídico protegido a través de dicha norma, y en el caso de que no sea así, deberá declarar su atipicidad. Adquiere de esta manera el bien jurídico un papel central en la interpretación de los tipos penales ${ }^{72}$.

A pesar de la importancia práctica de esta vertiente del principio que venimos comentando, son varios los supuestos en los que la jurisprudencia ha desconocido la vigencia del principio de ofensividad como límite en el momento de interpretación y aplicación de la ley. Esto ha ocurrido cuando se ha enfrentado con supuestos de anticipación de la protección penal: tentativa y delitos de peligro abstracto ${ }^{73}$.

Desde nuestro punto de vista, el bien jurídico como límite al ius puniendi adquiere mayor importancia en el momento de interpretación y aplicación de la ley que en el momento legislativo debido al amplio margen que posee el legislador para elegir, y a veces incluso configurar, los bienes jurídicos que son merecedores de la protección penal, con el único límite de que no estén constitucionalmente proscritos y sean socialmente relevantes. Aparte, es mayor el control por parte del Tribunal Constitucional que se puede llevar a cabo sobre la actividad de los Jueces y Tribunales que la que se puede realizar en relación con la actividad del legislador. Puesto que el criterio del «bien jurídico constitucionalmente legítimo y socialmente relevante», no se muestra como un límite suficiente para la actividad del legislador, es necesario buscar y tener en cuenta otros criterios ulteriores.

71 Expresión adoptada por GARCÍA RIVAS, El poder punitivo en el Estado democrático, Cuenca, 1996, p. 49, del autor italiano PALAZZO.

72 En este sentido, en la STC 111/1993, el Alto Tribunal asume la idea de que el principio de exclusiva protección de bienes jurídicos opera tanto en el momento legislativo como en el judicial, conectándola con el principio de interpretación conforme a la Constitución. De esta manera se conectaría la garantía material del bien jurídico con la garantía formal del principio de legalidad, adquiriendo esta última una dimensión material. GARCÍA RIVAS, El poder punitivo..., cit., p. 49.

73 Cfr. AGUADO CORREA, El principio constitucional..., cit., pp. 166 y ss. 


\section{Principio de intervención mínima: principio de subsidiariedad y principio de fragmentariedad}

Una vez afirmado que tan sólo son merecedores de tutela penal los bienes constitucionalmente legítimos y socialmente relevantes frente a comportamientos que los lesionen o los pongan en peligro, cabe plantearse la cuestión de si el legislador está obligado a protegerlos penalmente. A esta cuestión debe responderse de una forma negativa, salvo para los casos en los que así se contemple expresamente. La doctrina contemporánea se muestra casi unánime en considerar que la existencia de un bien jurídico merecedor de tutela penal no es suficiente para justificar la creación de un tipo penal: el bien jurídico debe necesitar dicha protección penal para llegar a convertirse en un bien jurídico penal ${ }^{74}$. Podemos afirmar que en el plano político-criminal los conceptos de merecimiento y necesidad de pena, tal y como vienen siendo concebidos por la mayoría de la doctrina ${ }^{75}$, se asumen como fórmula concentrada de los principios jurídicos constitucionalmente consagrados - que delimitan el horizonte de la criminalización ${ }^{76}$-, y más concretamente de alguno de los subprincipios que conforman el principio de proporcionalidad en sentido amplio ${ }^{77}$ : el principio de idoneidad y el principio de necesidad. Así, el concepto de merecimiento de pena expresa el principio de protección exclusiva de bienes jurídicos y el principio de fragmentariedad, en tanto que el concepto de necesidad de pena no es sino una expresión de los principios de idoneidad y de subsidiariedad.

El principio de intervención mínima estaría integrado por los postulados del carácter fragmentario del Derecho penal y el carácter de ultima ratio o subsidiario del Derecho penal $^{78}$. En virtud de este último, el Derecho penal tan sólo debe ser utilizado como ultima

74 La doctrina se muestra casi unánime en este sentido. Cfr. para las referencias doctrinales AGUADO CORREA, El principio constitucional..., cit., p. 176, n.p.p. 205.

75 En relación con el contenido de los conceptos de merecimiento y necesidad de pena, a pesar de que la mayoría de los autores coinciden sobre el mismo, cfr. AGUADO CORREA, El principio constitucional..., cit., p. 178, n.p.p. 207, algunos autores introducen una serie de matizaciones. Así, SCHÜNEMANN, «Der strafrechtliche Schutz von Privatgeheimnissen», ZStW, 1978, pp. 54 y ss.; o VOLK, «Entkriminalisierung durch Strafwürdigkeitskriterien jenseits des Deliktsaufbaus», ZStW, 1985, p. 899.

76 Vid., en este sentido, VOLK, «Entkriminalisierung durch Strafwürdigketiskriterien...», ZStW, 1985, pp. 873 y 874 ; DA COSTAANDRADE, «Merecimiento y necesidad de tutela penal como referencias de una doctrina teleológico-racional del delito», en Fundamentos de un sistema europeo de Derecho penal. Libro Homenaje a Claus Roxin, Barcelona, 1995, p. 165. Para ulteriores referencias doctrinales vid. AGUADO CORREA, El principio constitucional..., cit., p. 179, n.p.p. 209.

77 Tan sólo en el caso de que se adopte la postura de SHÜNEMANN, «Methodologische Prolegomena zur Rechtsfindung im Besonderen Teil des Strafrechts», en Festschrift für Bockelman, München, 1979, pp. 129 y ss., sobre la concepción del merecimiento y de la necesidad de pena, podemos afirmar que estos conceptos se asumen como fórmula concentrada del principio constitucional de proporcionalidad en sentido amplio: principio de idoneidad, principio de necesidad y principio de proporcionalidad en sentido estricto. Cfr. AGUADO CORREA, El principio constitucional...,cit., p. 179, n.p.p. 209.

78 La mayoría de la doctrina considera que tanto el carácter fragmentario del Derecho penal, así como el carácter de ultima ratio, constituyen concreciones o manifestaciones del principio de intervención mínima, cfr. AGUADO CORREA, El principio constitucional...,cit., p. 182. 
ratio, es decir, cuando no existan medios menos lesivos para proceder a la protección del bien jurídico en cuestión. Con la expresión carácter fragmentario del Derecho penal se quiere hacer referencia a que el Derecho penal no ha de sancionar todos los ataques a los bienes jurídicos penales, sino tan sólo aquellos que resulten más graves para los bienes jurídicos fundamentales.

El Tribunal Constitucional, por su parte, se ha referido en repetidas ocasiones a la vigencia del principio de intervención mínima o a alguno de sus postulados ${ }^{79}$. Cuando en la Sentencia 55/1996 el Tribunal Constitucional se refiere al requisito de la necesidad habla de «la existencia o no de medidas alternativas menos gravosas, pero de la misma eficacia que la analizada».

El principio de subsidiariedad del Derecho penal implica que éste tan sólo debe ser utilizado únicamente allí donde sea imprescindible para la protección de la sociedad $^{80}$, lo cual significa su utilización, exclusivamente, para la protección de aquellos bienes jurídicos que sean indispensables para la convivencia de los hombres y que no pueden ser protegidos eficazmente por otros medios distintos al Derecho penal ${ }^{81}$. Únicamente en caso de que estos mecanismos se muestren como insuficientes para la protección del bien jurídico, el legislador podrá acudir a las sanciones penales. Pero no olvidemos que la utilización de las sanciones penales requiere una comprobación previa: que el comportamiento que se pretende amenazar con estas sanciones es idóneo para lesionar o poner en peligro el bien jurídico en cuestión, que nos encontremos ante un comportamiento merecedor de pena ${ }^{82}$. En caso contrario, el recurso a la pena resultaría más dañoso

79 En la Sentencia 53/1985 hablaba de «establecer un sistema legal para la defensa de la vida que suponga una protección efectiva de la misma y que, dado el carácter fundamental de la vida, incluya también como última garantía las normas penales. Ello no significa que dicha protección haya de revestir carácter absoluto...». En el Fundamento Jurídico 4 de la STC 241/1991 se afirma «... que ha de estimarse desproporcionada respecto del fin perseguido por la norma penal y que pugna con el principio de intervención mínima que preside el orden penal...».

80 KAUFMANN, «Subsidiaritätsprinzip und Strafrecht», en Grundfragen der gesamten Strafrechtswissenschaft. Festschrift fürHenkel zum 70 Geburtstag, Berlín, New York, 1974, p. 102; JESCHECK, Leipziger Kommentar. Großkommentar, 1. ${ }^{a}$ Lieferung. Einleitung, Nm. 3; JESCHECK/WEIGEND, Lehrbuch des Strafrechts., cit., § 4, II, 2, p. 26. En la BVerfGE 39, 1 (47), se afirma que «la norma penal representa, en cierta medida, la ultima ratio del instrumental del legislador».

81 KAUFMANN, «Subsidiaritätsprinzip und Strafrecht», en Grundfragen der gesamten Strafrechtswissensschaft. Festschrift für Henkel, p. 102; RUDOLPHI, en Systematischer Kommentar..., cit., previo § 1, Nm. 14; JESCHECK, en Leipziger Kommentar..., Einleitung, Nm. 3; BVerfGE 88, 203 (258). La Corte constitucional italiana ha subrayado que entre los «límites sustanciales» con los que se encuentra el legislador a la hora de criminalizar, está el «principio de subsidiariedad, en virtud del cual, la criminalización, constituyendo la ultima ratio, debe intervenir en tanto que el resto de las ramas del ordenamiento jurídico no ofrezcan una tutela adecuada a los bienes jurídicos» (Sentencia de 25 de octubre de 1989).

82 Como acertadamente ha puesto de manifiesto RUDOLPHI, Systematischer Kommentar..., cit., previos al § 1, Nm. 11a, el hecho de afirmar que la función del Derecho penal consiste en la protección de bien jurídico, no conlleva que cualquier tipo penal que persiga este fin se encuentra sin más legitimado constitucionalmente. GÜNTHER, «Die Genese eines Straftatbestandes. Eine Einführung in Fragen der Strafgesetzgebungslehre», JuS, 1978, pp. 9 
que útil y sería ilegítimo ${ }^{83}$. La necesidad de tutela penal significa, además de que la tutela penal es adecuada y necesaria para la prevención de la dañosidad social, que la intervención penal en el caso concreto no va acompañada de efectos secundarios desproporcionadamente lesivos, de consecuencias accesorias negativas ${ }^{84}$. En este sentido también se ha pronunciado el Tribunal Constitucional alemán, para quien las consecuencias accesorias negativas pueden llegar a cuestionar la aptitud general de la norma penal ${ }^{85}$.

El problema de la elección entre los distintos mecanismos se ve acrecentado por la insuficiencia de los datos procedentes de investigaciones sociológico-empíricas, concernientes a en qué medida el Derecho penal es necesario para conseguir los fines de prevención y en qué medida las sanciones civiles o administrativas o los mecanismos de control social, siendo igualmenteidóneos y eficaces para conseguir los mismos, constituyen una alternativa menos gravosa $^{86}$. Las investigaciones empíricas, al igual que ocurre con el principio de idoneidad, constituyen un elemento fundamental para conseguir la realización del principio de intervención mínima, puesto que se trata de principios de naturaleza empírica frente a la naturaleza eminentemente normativa del principio de proporcionalidad en sentido estricto ${ }^{87}$.

y ss.; GRASSO, «Die Vorverlegung des Strafrechtsschutzes durch Gefährdungsund Unternehmensdelikte im italianischen Strafrecht», en Beiheft zur ZStW, 1987, pp. 86 y 87, comienza las consideraciones de lege ferenda sobre los delitos de peligro, afirmando la necesidad de buscar límites a la anticipación de la tutela penal en la Constitución. Vid. también FIANDACA, «Il "bene giuridico" come problema teorico e como criterio di politica criminale», RIDPP, 1982, pp. 79 y ss. MUÑOZ CONDE, en MUÑOZ CONDE/GARCÍA ARÁN, Derecho penal..., cit., p. 81, afirma que cuando existen dudas sobre si una determinada conducta es merecedora de pena debe elegirse la vía de la impunidad o la despenalización (in dubio pro libertate).

83 Vid. en este sentido FIANDACA/MUSCO, Diritto penale. Parte Generale, 5. ${ }^{\mathrm{a}}$ ed., Bologna, 1992, p. 7.

84 Se pronuncian en este sentido HASSEMER/MUÑOZ CONDE, Introducción a la Criminología..., cit., pp. 65 y ss. SILVA SÁNCHEZ, Aproximación al Derecho..., cit., 289; GARCÍA-PABLOS, «Sobre el principio de intervención mínima...», en Estudios penales y jurídicos..., cit., p. 259, citando a SILVA SÁNCHEZ; SCHÜNEMANN, «Methodologische Prolegomena zur Rechtsfindung im Besonderen Teil des Strafrechts», en Festschrift für Bockelmann, München, 1979, p. 129; OTTO, «Konzeption und Grundsätze des Wirtschatsstrafrechts (einschließlich Verbraucherschutz)», ZStW, 1984, p. 362; DA COSTA ANDRADE, «Merecimiento de pena y necesidad de tutela...», en Fundamentos de un sistema europeo..., cit., p. 164.

85 BVerfGE 88, 203 (265 y ss.).

86 Cfr. DÖLLING, «Generalprävention durch Strafrecht», ZStW, 102 (1990), pp. 19 y 20; SILVA SÁNCHEZ, Aproximación al Derecho..., cit., pp. 19 y 20; WEIGEND, «Bewältigung von Beweisschwierigkeiten durch Ausdehnung des materiallen Strafrechts?», Festschrift für Triffterer zum 65 Geburtstag, Wien-New York, 1996, p. 709; ZUGALDÍA ESPINAR, Fundamentos de Derecho..., cit., p. 241; DA COSTA ANDRADE, «Merecimiento de pena y necesidad de tutela penal...», en Fundamentos de un sistema europeo..., cit., p. 164; LAGODNY, Strafrecht vor den Schranken..., cit., p. 362.

87 Destacan la naturaleza empírica del principio de idoneidad y de necesidad, frente a la naturaleza normativa del principio de proporcionalidad en sentido estricto, LERCHE, Übermaß und Verfassungsrecht. Zur Bindung des Gesetzgebers an die Grundsätze der Verhältnismäßigkeit und der Erforderlichkeit, Köln 1961, pp. 19 y ss.; HIRSCHBERG, Der Grundsatz der Verhältnismässigkeit, Göttingen, 1981, pp. 59 y ss. y 158 y ss.; GÜNTHER, Straftrechtswidrigkeit und Strafunrechtsauschluß, cit., pp. 190 y ss.; LAGODNY, Strafrecht vor den Schranken..., cit., pp. 179 y ss.; GONZÁLEZ-CUÉLLAR SERRANO, Proporcionalidad y derechos fundamentales..., cit., p. 155; SÁNCHEZ GARCÍA, «El principio constitucional de proporcionalidad en Derecho penal», La Ley, 1994, p. 1118. 
No obstante, ante la insuficiencia de las investigaciones empíricas es necesario acudir a otros criterios, encontrándose entre ellos la propia experiencia del legislador: es, por consiguiente, esta insuficiencia la que propicia la excesiva prerrogativa de decisión que se le otorga al legislador ${ }^{88}$. En este sentido, el propio Tribunal Constitucional ha señalado que el juicio de necesidad corresponde al legislador y que el amplio margen de libertad del que goza responde, en parte, a la complejidad de la tarea (STC 55/1996, FJ 8). Por supuesto, el legislador, a diferencia de lo que le ocurre al Juez o Tribunal, no ha de atender al criterio del menoscabo de los derechos de la concreta persona, sino que debe partir del menoscabo puede sufrir la totalidad de los destinatarios de la norma ${ }^{89}$.

Además del carácter empírico de este principio, podemos afirmar que nos encontramos ante un principio comparativo, en tanto que, a diferencia de lo que ocurre en el principio de aptitud y en el de proporcionalidad en sentido estricto, el legislador ha de buscar medidas alternativas menos gravosas pero igualmente eficaces ${ }^{90}$. Este último aspecto es muy importante: no se trata de buscar una alternativa menos gravosa, sino una alternativa menos gravosa igualmente eficaz o idónea. El Tribunal Constitucional así lo ha reconocido en la STC 55/1996 cuando se refiere al control que él puede llevar a cabo «... acerca de la existencia o no de medidas alternativas menos gravosas pero de la misma eficacia que la analizada...» (FJ 8), y lo ha reiterado en la STC 161/1997 al afirmar que «las medidas alternativas han de ser, pues, palmariamente de menor intensidad coactiva y de una funcionalidad manifiestamente similar a la que se critique por desproporción» (FJ 11)

Al igual que sucedía con el principio de exclusiva protección de bienes jurídicos, el principio de subsidiariedad tampoco nos ofrece un catálogo de bienes jurídicos a proteger, sino tan sólo supone un límite negativo para el legislador, quien en todo momento es libre de no atender al mismo. La cuestión es que cuando existan dudas sobre si existe un medio menos lesivo y grave que el penal para dotar de protección a un determinado bien jurídico, el legislador posee un amplio ámbito de decisión, con lo cual el principio de subsidiariedad es más una orientación político-criminal (Richtlinie) que una imposición ${ }^{91}$. Se trata de una cuestión de decisiones político-criminales; de hasta qué punto el legislador ha de convertir un ilícito

88 LAGODNY, Strafrecht vor den Schranken..., cit., p. 180. El Tribunal Constitucional alemán ha afirmado que en ocasiones son suficientes consideraciones de practicabilidad y efectividad, BVerfGE 68, 193 (219).

89 Lo recuerda en el seno de la doctrina alemana, LAGODNY, Strafrecht vor den Schranken..., cit., pp. 345 y 365 . En el seno de nuestra doctrina, ARROYO ZAPATERO, «Derecho penal económico y Constitución», RP, núm. 1 (1997), p. 5 .

90 Vid. en este sentido lo afirmado en el FJ 8 STC 55/1996 y por GONZÁLEZ-CUÉLLAR, Proporcionalidad y derechos fundamentales en el proceso penal, Madrid, 1990, p. 189.

91 Vid. ROMANO, «"Merecimiento de pena", "Necesidad de pena" y teoría del delito», en Fundamentos de un sistema europeo de Derecho penal. Libro homenaje a Claus Roxin, Barcelona, 1995, p. 142; LAGODNY, Strafrecht vor den Schranken..., cit., p. 366. 
penal en un ilícito administrativo o bien dejarlo sin sanción alguna ${ }^{92}$. Pero siempre que el legislador atienda en la medida de lo exigible al principio de subsidiariedad, se facilitará una intervención penal racional, practicable y efectiva ${ }^{93}$.

En virtud del principio de fragmentariedad, el Derecho penal no debe proteger a los bienes jurídico-penales frente a cualquier tipo de ataque, sino únicamente frente a aquellos que resulten más graves o peligrosos, ya sea por razones objetivas, ya por razones subjetivas $^{94}$. Como ya dijera ROXIN, seguramente nada contribuye más al aumento de la criminalidad que la penalización de los hechos de mínima gravedad ${ }^{95}$. El olvido del respeto del principio de fragmentariedad por parte del legislador conduce a tal inflación punitiva que provoca la degradación de la función de la pena ${ }^{96}$.

En el principio de fragmentariedad no sólo inciden consideraciones utilitaristas, como ocurre fundamentalmente con el principio de idoneidad y de subsidiariedad, sino que también inciden en él consideraciones de proporcionalidad ${ }^{97}$. Eso no significa, desde nuestro punto de vista, que el carácter fragmentario se corresponda con el principio de proporcionalidad en sentido estricto, si bien tampoco cabe desconocer que en los casos en los que el legislador no ha respetado el principio de fragmentariedad tampoco respetará el principio de proporcionalidad en sentido estricto ${ }^{98}$. El carácter fragmentario del Derecho penal constituye una concreción o uno de los postulados que integran el principio de intervención mínima, y cuando se alude al mismo se hace referencia a la necesidad de que el Derecho penal no sancione todas las conductas lesivas de los bienes jurídicos por él protegidos, sino aquellas que resulten más peligrosas para los mismos. Cuando se alude al principio de proporcionalidad en sentido estricto se hace referencia a la exigencia de proporcionalidad entre la gravedad de la pena y la gravedad del injusto, exigencia que sólo de una forma parcial se tiene en cuenta cuando se habla de carácter fragmentario.

92 ROXIN, Strafrecht. Allgemeiner Teil..., cit., § 2, XI, 31, p. 25.

93 Habla QUINTERO OLIVARES, Curso de Derecho..., cit., p. 69, de los principios de racionalidad, practicabilidad y efectividad.

94 La formulación de este principio varía muy poco de unos autores a otros, vid. AGUADO CORREA, El principio constitucional..., cit., p. 203, n.p.p. p. 309.

95 ROXIN, «Sinn und Grenzen staatlicher Strafe», JuS, 1966, pp. 14 y ss.

96 COBO/VIVES, Derecho penal..., cit., p. 78, afirman que con razón reclamaba VON LISZT la restauración de la vigencia de la regla «minima non curat praetor».

97 Vid., en este sentido, SILVA SÁNCHEZ, Aproximación al Derecho..., cit., p. 246, n.p.p. 284.

98 ARROYO ZAPATERO, «Derecho penal económico y Constitución», RP, núm. 1 (1997), p. 6, sostiene que la proporcionalidad en sentido estricto es lo que se invoca cuando se habla del carácter fragmentario o del merecimiento de pena de un comportamiento. 


\section{Principio de necesidad de la pena}

Del principio de intervención mínima no sólo se deriva que el Derecho penal no debe intervenir donde no es necesario porque el bien no necesita ser tutelado o porque puede serlo por medios menos gravosos, sino que del mismo también se derivan una serie de consecuencias en el momento de interpretación y aplicación de las leyes penales ${ }^{99}$. Para los casos en los que no sea necesario castigar o no sea necesario castigar con una pena tan grave, el Código Penal ha de prever mecanismos que permitan prescindir de la pena o que permitan sustituirla por otra menos grave o incluso por medidas de otra índole ${ }^{100}$. El propio Tribunal Constitucional, en la Sentencia de 15 de octubre de 1982 (STC 62/1982, FJ 5), proyecta la exigencia de necesidad de pena tanto sobre el plano de la conminación penal abstracta como sobre la imposición concreta de la pena.

\section{IV.3.C. Principio de proporcionalidad en sentido estricto}

\section{Introducción}

Junto al merecimiento y la necesidad de pena constituye un requisito indispensable para considerar punible un determinado comportamiento, que exista una proporción entre la pena y el delito. Por lo tanto, la pena habrá de aparecer, en abstracto y en concreto, tanto merecida como necesitada y proporcionada ${ }^{101}$. No se trata una exigencia novedosa, sino que ya reclamaba expresamente la necesidad de proporción entre los delitos y las penas BECCARIA $^{102}$. El Tribunal Constitucional español alude al mismo como «la vertiente del principio de proporcionalidad que se refiere a la comparación entre la entidad del delito y la entidad de la pena (proporcionalidad en sentido estricto)» (STC 55/1996, FJ 9). Desde nuestro punto de vista, el principio de proporcionalidad en sentido estricto implica una relación

99 Destacan la importancia de considerar el ámbito propio de incidencia del principio de intervención mínima en el momento de interpretación y aplicación de la ley, COBO/VIVES, Derecho penal..., cit., p. 79; ARROYO ZAPATERO, «Fundamento y función del sistema penal: el programa penal de la Constitución», RJCLM, núm. 1 (1987), pp. 104 y 105; CARBONELL MATEU, Derecho penal: concepto..., cit., p. 200; MORILLAS CUEVA, Curso de Derecho penal español. Parte General, Madrid, 1996, p. 41; SILVA SÁNCHEZ, Aproximación al Derecho..., cit., p. 247, distingue una manifestación externa y otra interna del principio de subsidiariedad. En virtud de esta última, se deberá prescindir de una pena siempre que quepa esperar parecidos efectos preventivos de otra sanción penal menos gravosa.

100354 COBO/VIVES, Derecho penal..., cit., p. 79; ARROYO ZAPATERO, «Fundamento y función del sistema penal...», RJCLM, núm. 1 (1987); SILVA SÁNCHEZ, Aproximación al Derecho..., cit., p. 248, afirma que resulta obligado prescindir de la ejecución de la pena, si ello no merma la prevención general, en virtud de la vigencia del principio de intervención mínima. Sobre las manifestaciones de este principio, vid. AGUADO CORREA, El principio constitucional..., cit., pp. 217.

101 En el mismo sentido, LUZÓN PEÑA, «La relación del merecimiento de pena y de la necesidad de pena con la estructura del delito», en Fundamentos de un sistema europeo..., cit., p. 120.

102 BECCARIA, De los delitos y de las penas..., cit., pp. 28 y 29. 
de proporcionalidad entre la gravedad del injusto y la gravedad de la pena en el momento legislativo; en el momento judicial, que la pena resulte proporcionada a la gravedad del hecho concreto cometido.

El hecho de que entre la pena y el delito no exista relación natural alguna no impide que la pena deba ser adecuada a éste en alguna medida. Entre los mismos existe un nexo legal y convencional, siendo ésta la razón por la que le corresponde al legislador en un primer momento y posteriormente al juez, la elección de la cantidad y la calidad de la pena en relación con la naturaleza y la gravedad del hecho ${ }^{103}$. Lo cierto es que hay que reconocer la heterogeneidad que existe entre la pena y el delito ${ }^{104}$ y que solamente son criterios pragmáticos basados en consideraciones de oportunidad los que sirven al legislador para determinar la relación de proporción que deba guardar un comportamiento penalmente típico con la sanción que se le asigna (STC 55/1996, FJ 6; STC 161/1997, FJ 12). No obstante, de lo que no cabe duda es que, aun cuando se afirme que es imposible medir la gravedad del injusto individualmente considerado, es posible afirmar, atendiendo al principio de proporcionalidad en sentido estricto, que, desde el punto de vista interno, si dos delitos se castigan con la misma pena, es que el legislador los considera de gravedad equivalente; en tanto que si la pena prevista para un delito es más severa que la prevista para otro, el primer delito es considerado por el legislador más grave que el segundo. De lo dicho se deriva que, si desde el punto de vista externo, dos delitos no son considerados de la misma gravedad, considerándose uno más grave que el otro, y se sancionan ambos con la misma pena o el que se considera más grave se sanciona con una pena menor, se estaría vulnerando el principio de proporcionalidad en sentido estricto ${ }^{105}$.

$\mathrm{Al}$ abarcar el estudio de este principio es muy importante distinguir los dos ámbitos en los que actúa, el legislativo y el judicial, y así lo ha manifestado reiteradamente el propio Tribunal Constitucional ${ }^{106}$, quien se ha encargado de subrayar que el principio de proporcionalidad es ante todo de un principio dirigido al legislador (STC 65/1986). En tanto que la exigencia de proporcionalidad abstracta entendida como proporción entre la gravedad del injusto y la gravedad de la pena con la que éste se conmina se dirige al legislador, la exigencia de proporcionalidad concreta entendida como la necesaria proporción entre la gravedad

103 Vid. en este sentido FERRAJOLI, Derecho y razón..., cit., p. 398.

104 Señala FERRAJOLI, Derecho y razón..., cit., p. 451, que uno de los autores más críticos con la posibilidad de comparar la pena con el delito fue BOVIO, quien trató de demostrar analíticamente el carácter ilusorio de cualquier cálculo dirigido a establecer una proporción entre la entidad de la pena y la entidad del delito.

105 Vid. en este sentido FERRAJOLI, Derecho y razón..., cit., p. 402. Esto también se puede deducir de lo afirmado por el Tribunal Constitucional en la Sentencia de 2 de octubre de 1997, en el Fundamento Jurídico decimotercero.

106 En la Sentencia 111/1993, FJ 3, distingue claramente los distintos ámbitos en los que opera el principio de proporcionalidad. 
del hecho concreto cometido y la pena aplicada al autor, tiene como destinatario al Juez o Tribunal. Pasamos a referirnos separadamente a algunos de los problemas que el principio de proporcionalidad estricto plantea en el momento legislativo y en el momento judicial.

\section{Proporcionalidad abstracta}

La libertad del legislador penal se encuentra sujeta, por consiguiente, al respeto del valor de justicia del Estado de Derecho, de la interdicción de la arbitrariedad y de la dignidad de la persona, pero siempre que los respete posee un amplio poder de decisión. En este sentido, el principio de proporcionalidad de las penas es una fórmula vacía en tanto que no se establezcan los criterios de proporcionalidad que son constitucionalmente legítimos ${ }^{107}$. Por consiguiente, hay que traducir el principio de proporcionalidad en una serie de directivas más precisas para el legislador, encontrándonos ante una tarea ciertamente delicada, a pesar de la simplicidad estructural de este principio ${ }^{108}$. Con carácter general, se puede afirmar que la gravedad de la pena ha de ser proporcional a la gravedad del hecho antijurídico, a la gravedad del injusto, siendo fundamental la gravedad intrínseca del hecho, es decir, el desvalor de acción y desvalor de resultado ${ }^{109}$.Tradicionalmente se ha reconocido que la importancia del bien jurídico agredido es un factor esencial, si bien no el único que habrá de tener en cuenta el legislador a la hora de determinar la pena, ya que no puede desconocer el grado de la ofensa al bien jurídico protegido ${ }^{110}$, es decir, la gravedad del ataque. Ésta puede ser considerada tanto bajo el aspecto extensivo, es decir, el número de bienes a los que afecta ${ }^{111}$, como bajo el aspecto intensivo. Ya que en virtud del principio de proporcionalidad en sentido estricto debe existir una relación de proporcionalidad entre la gravedad de la sanción y la gravedad de la ofensa, si la ofensa no reúne un cierto nivel de gravedad, es decir, si es exigua, no puede seguir considerándose proporcional a la sanción penal: «Minima non curat praetor»"112. Por este motivo, es por el que sostenemos que el principio

107 En este sentido se manifiestan BACIGALUPO, «¿Tienen rango constitucional las consecuencias del principio de culpabilidad?», La Ley, 1982, p. 941; GARCÍA ARÁN, Los criterios de determinación de la pena en el Derecho español, Barcelona, 1982, p. 212.

108 Vid. lo afirmado por DOLCINI, «Sanzione penale o sancione amministrativa: problemi di scienza della legislazione», RIDPP, 1984, p. 613. BAURMANN, Zweckrationalität und Strafrecht: Argumente für ein tatbezogenes Massnahmerecht, Opladen, 1987, p. 255

109 LUZÓN PEÑA, Curso de Derecho..., cit., p. 85; el mismo, «Principio de igualdad, Derecho penal de hecho y prevención especial: equilibrio y tensiones», en Estudios penales, cit., p. 308.

110 ANGIONI, Contenuto e funzioni del concetto di bene giuridico, Milano, 1983, cit., pp. 205 y ss.; CARBONELL MATEU, Derecho penal: concepto..., cit., p. 203; DOLCINI, «Sanzione penale o sanzione amministrativa...», RIDPP, 1984, p. 613, afirma que junto con el rango del bien jurídico agredido, juega un papel decisivo la gravedad de la ofensa

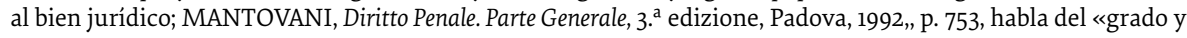
la cantidad de la ofensa».

111 A este aspecto hace referencia el Tribunal Constitucional en el FJ 13 de la Sentencia de 2 de octubre de 1997.

112 ANGIONI, Contenutto e funzioni..., cit., p. 209. 
de insignificancia responde fundamentalmente a la exigencia del respeto del principio de proporcionalidad en sentido estricto: no se puede seguir considerando proporcional la pena prevista por el legislador para determinados comportamientos, cuando nos encontremos ante supuestos en los que el contenido de injusto es mínimo. Para estos supuestos se debe prever la posibilidad de que el Juez deje de aplicar la pena por desproporcionada ${ }^{113}$. En relación con la gravedad de la ofensa nos interesa destacar lo afirmado por el Tribunal Constitucional en la Sentencia de 2 de octubre de 1997 (FJ 13): «No siempre el legislador considera en el CP vigente de menor gravedad o merecedores de menor sanción los comportamientos de incidencia más lejana en el bien finalmente protegido que los que afectan de una manera más inmediata. El peligro abstracto o remoto puede merecer un castigo mayor que el próximo...». Por lo tanto, y en virtud de lo manifestado por el Tribunal Constitucional, no es contrario al principio de proporcionalidad estricto amenazar con una pena más grave los comportamientos que suponen un peligro abstracto de un bien jurídico, frente a aquellos que lo ponen en peligro concreto.

Otro factor que influye es el elemento subjetivo del desvalor de la acción: el dato de que el hecho haya sido cometido dolosa o imprudentemente habrá de ser tenido en cuenta a la hora de determinar la proporcionalidad entre delito y pena, en cuanto demostrativo de la mayor o menor gravedad del delito, respectivamente ${ }^{114}$. El legislador no puede sancionar con la misma pena el ataque doloso o imprudente a un mismo bien jurídico.

Para un sector doctrinal, otro de los criterios que debe tener en cuenta el legislador en la determinación de la pena, es la trascendencia social del hecho: el legislador no puede ser ajeno a la importancia social del hecho, a la «nocividad social» del ataque del bien jurídico, de manera que en un Estado democrático, el legislador debe ajustar la gravedad de las penas a la trascendencia que para la sociedad tienen dichos hechos ${ }^{115}$.Tanto el grado de ejecución

113 Sobre el principio de insignificancia vid. AGUADO CORREA, El principio constitucional, cit., pp. 23 y ss.

114 MUÑOZ CONDE, en MUÑOZ CONDE/GARCÍA ARÁN, Derecho penal..., cit., p. 85; OCTAVIO DE TOLEDO, Sobre el concepto de Derecho Penal, Madrid, 1984, p. 364; HASSEMER, Fundamentos de Derecho penal, Barcelona, 1984, pp. 280 y 281; GARCÍA RIVAS, El poder punitivo..., cit., p. 61; GIMBERNAT ORDEIG, «¿Tiene un futuro la dogmática jurídico-penal», en Estudios de Derecho penal, cit., p. 154; LUZÓN PEÑA, Curso de Derecho..., cit., pp. 85 y 87; Por el contrario, ROXIN, «iQué queda de la culpabilidad en Derecho penal?», CPC, núm. 30 (1986), p. 674, afirma que «el principio de culpabilidad posibilita, además, una graduación del marco penal según si el autor ha actuado dolosa o imprudente; permite también, en el seno de estas categorías, nuevas graduaciones de la pena, que se fundan en si el autor actuó con dolo directo de primer grado, de segundo grado o eventual, o con imprudencia temeraria»; también GARCÍA RIVAS, El poder punitivo..., cit., p. 60, considera que la graduación de la respuesta penal, según los grados de participación interna en el delito, constituye uno de los postulados del principio de culpabilidad.

115 Ésta no es una idea nueva, sino que ya fue expresada por BECCARIA, De los delitos $y$ de las penas, cit., p. 35. al comenzar el capítulo que lleva por rúbrica «Errores en la graduación de las penas». Vid., en este sentido, MIR PUIG, Introducción a las bases del Derecho penal. Concepto y método, Barcelona, 1976, p. 159; el mismo, en Derecho penal..., cit., p. 100; GARCÍA-PABLOS, Derecho penal, Introducción, cit., p. 291; SILVA SÁNCHEZ, Aproximación al Derecho..., cit., p. 260; ARROYO ZAPATERO, «Fundamento y función del sistema penal...», RJCLM, núm. 1 (1987), p. 105. 
como las formas de participación en el delito son criterios que el legislador ha de tener en cuenta cuando establece la gravedad de la pena.

Sin embargo, a pesar de la simplicidad que ofrece a primera vista el problema de la proporcionalidad de la pena, como afirmó DORADO MONTERO ${ }^{116}$, éste resulta más complicado de lo que en un principio pudiera pensarse, puesto que no es otro que el problema de la finalidad penal, ya que la pena proporcionada equivale a la pena adecuada al fin. Esta idea la expresó en los siguientes términos: «Me parece que el problema de la proporcionalidad o justicia de las penas, dentro del propio espíritu de los que hablan de él, va resultando más complicado de lo que pudiera creerse. Y es que semejante problema no es otro que el de la finalidad penal, toda vez que pena proporcionada vale lo mismo que pena adecuada al fin por la misma perseguido; y siendo variadísimos y a menudo hasta antitéticos los fines que con la pena se quieren obtener, forzosamente tiene que resultar difícil la organización del respectivo sistema de medios penales» ${ }^{117}$.

Y así lo ha considerado en parte el Tribunal Constitucional, en el FJ 6 de la Sentencia 55/1996, y lo ha reiterado en el FJ 9 de la Sentencia de 2 de octubre de 1997, al afirmar que «... el legislador, al establecer las penas, carece, obviamente, de la guía de una tabla precisa que relacione unívocamente medios y objetivos, y ha de atender no sólo al fin esencial y directo de protección al que responde la norma, sino también a otros fines legítimos que puede perseguir con la pena y a las diversas formas en que la misma opera y que podrían catalogarse como sus funciones o fines inmediatos: a las diversas formas en que la conminación abstracta de la pena y su aplicación influyen en el comportamiento de los destinatarios de la norma - intimidación, eliminación de la venganza privada, consolidación de las convicciones éticas generales, refuerzo del sentimiento de fidelidad al ordenamiento, resocialización, etc. - y que se clasifican doctrinalmente bajo las denominaciones de prevención general y prevención especial». Como se desprende de estos pronunciamientos, el legislador, a la hora de establecer las penas, ha de atender tanto a los fines de prevención general, positiva y negativa, como a los de prevención especial - resocialización-. Por consiguiente, en la conminación penal abstracta, si bien el legislador ha de partir de criterios de proporcionalidad entre el injusto y la pena, su decisión debe incorporar además criterios de

116 «Sobre la proporción penal», RGLJ, 1916, p. 39.

117 DORADO MONTERO, «Sobre la proporción penal», RGLJ, 1916, p. 39. Critica este autor - p. 10 - que al implicar la idea de proporcionalidad una comparación y afirmarse que la pena ha de guardar proporción con el delito por el cual se aplica, se la considera grosso modo como el pago de una deuda que con el delito se contrae, siendo ésta la concepción retributiva. Pero ya el propio BECCARIA afirmó: «La verdadera medida de la proporcionalidad es el daño social del delito», prescindiendo de la idea estrictamente retributiva. 
prevención general y de prevención especial ${ }^{118}$. La consideración de criterios de prevención general en el momento legislativo se debe a que es ésta la función fundamental de la pena en el momento de conminación penal; la inclusión de criterios de prevención especial no es más que una consecuencia de la necesidad de vigencia de los principios de resocialización y de humanidad de las penas en las tres fases de la pena y no de manera exclusiva a la fase de imposición de la pena. Ahora bien, ¿qué relación existe entre la proporcionalidad y los fines de la pena? Como venimos reiterando, desde nuestro punto de vista, la exigencia de proporcionalidad es de carácter constitucional y se puede inferir del valor de justicia del Estado de Derecho, de la interdicción de la arbitrariedad de los poderes públicos y de la dignidad de la persona, constituyendo, por consiguiente, un límite constitucional a la función preventiva de la pena compatible con la misma ${ }^{119}$. Por este motivo, no compartimos la postura de aquellos que consideran la proporcionalidad como un postulado de la idea de retribución ${ }^{120}$ que, además, sirve a la necesidades de prevención ${ }^{121}$, ni la de aquellos autores que entienden la proporcionalidad entre la gravedad del injusto y la gravedad de la pena como una exigencia de la prevención general ${ }^{122}$, o la de aquellos otros que incluso sostienen que la proporcionalidad puede derivarse exclusivamente de la prevención gene$\mathrm{ral}^{123}$. Por otra parte, tampoco compartimos los planteamientos de quienes son partidarios de la prevención general positiva como fundamento de la pena y consideran que uno de los argumentos en favor de la misma frente a la prevención general intimidatoria, es que resulta más idónea para incorporar en su seno los contenidos de los principios que limitan la intervención penal, tales como el principio de proporcionalidad, el de humanidad... ${ }^{124}$. La teoría de la prevención general entendida de una forma correcta encerraría, según estos autores, dentro de sí misma, su propia limitación jurídico-estatal' ${ }^{125}$.Lo más rechazable de esta postura es que en el supuesto de que se consideren los principios limitadores de la pena como elementos o componentes de la función de prevención general positiva, pierden

118 QUINTERO OLIVARES, Curso de Derecho..., cit., p. 539; GARCÍA ARÁN, en MUÑOZ CONDE/GARCÍA ARÁN, Derecho penal..., cit., p. 553, no incluye la prevención especial. Para esta autora, en el momento de individualización legal de la pena predominan criterios de prevención general y proporcionalidad.

119 En el mismo sentido, aun cuando infieran el principio de proporcionalidad de otros artículos de la CE, OCTAVIO DE TOLEDO, Sobre el concepto..., cit., p. 367; SILVA SÁNCHEZ, Aproximación al Derecho..., cit., pp. 236 y 280.

120 Los partidarios de la idea de la retribución alegan que ésta es irrenunciable porque es la única, o la mejor manera de exigir y garantizar la proporcionalidad entre delitos y penas. Vid. BAJO FERNÁNDEZ, «Algunas observaciones sobre la teoría de la motivación de las normas», en Estudios penales, I, Madrid, 1977, pp. 38 y ss.

121 Vid. CEREZO MIR, Curso de Derecho penal español. Parte General, I, Introducción, 5. ${ }^{a}$ ed., Madrid, 1996, p. 28; GARCÍA-PABLOS, Derecho penal, Introducción, cit., p. 291.

122 Los autores de la Ilustración sostenían que más eficaz que la pena severa o cruel es la pena proporcionada al delito. Vid. BECCARIA, De los delitos y de las penas, cit., pp. 28 y ss.

123 MIR PUIG, Derecho penal..., cit., p. 100.

124 Tampoco comparte este planteamiento SILVA SÁNCHEZ, Aproximación al Derecho..., cit., pp. 237 y 259.

125 HASSEMER, Fundamentos del Derecho penal..., cit., p. 393. 
toda la capacidad crítica ${ }^{126}$ y de limitación que poseen cuando se reputan principios autónomos y, más aún, cuando se derivan de la propia Constitución.

Ahora bien, aun cuando la proporcionalidad no deriva de la prevención general, no cabe duda de que una y otra se encuentran vinculadas ${ }^{127}$. Y es que la experiencia ha demostrado que las penas más graves no son las más eficaces para obtener los objetivos prevencionistas, sino que las más eficaces son aquellas que resultan más adecuadas a la gravedad de los comportamientos, de manera que la pena proporcionada a la gravedad del hecho será también la más adecuada a la finalidad de tutela ${ }^{128}$. Así lo ha puesto de relieve, en parte, el propio Tribunal Constitucional en el FJ 6 de la Sentencia 55/1996, y lo ha reiterado en el FJ 9 de la Sentencia 161/1997, al afirmar: «Estos efectos (prevención general y especial) de la pena dependen a su vez de factores tales como la gravedad del comportamiento que se pretende disuadir, las posibilidades fácticas de su detección y sanción y las percepciones sociales relativas a la adecuación entre delito y pena ${ }^{129}$.

Pero tampoco cabe desconocer que, en algunos casos, la prevención y la proporcionalidad se hallan en conflicto: lo normal es que la gravedad de la pena no sea determinante de la eficacia preventiva, de forma que se favorece la coincidencia entre el interés de la proporcionalidad con el hecho y el de la intimidación, pero en otros casos el incremento de la pena por motivos de prevención, contrarios a la proporcionalidad en sentido estricto, desarrolla un efecto intimidatorio superior ${ }^{130}$. Desde nuestro punto de vista, existe una tendencia exagerada del legislador penal de intentar incrementar la eficacia preventiva del Derecho penal a través del aumento de las penas, que lleva a la merma de las garantías propias de un Estado de Derecho, entre las que se encuentra la proporcionalidad en sentido estricto.

Cuando se controla el respeto de la proporcionalidad en sentido estricto por parte del legislador se trata de contrapesar: por una parte, el menoscabo de derechos fundamentales que implica toda amenaza penal; $y$, por otra, la mejora que a través de la misma se consigue para la protección del bien jurídico ${ }^{131}$. En definitiva, si se produce un sacrificio excesivo del

126 Vid. la crítica formulada por SILVA SÁNCHEZ, Aproximación al Derecho..., cit., p. 235.

127 OCTAVIO DE TOLEDO, Sobre el concepto..., cit., p. 368.

128 COBO/VIVES, Derecho penal..., cit., p. 80.

129 En este sentido se ha manifestado un gran número de autores entre ellos, BECCARIA, De los delitos y de las penas..., cit., pp. 103 y 105»; PÉREZ MANZANO, Culpabilidad y prevención..., cit., p. 229; OCTAVIO DE TOLEDO, Sobre el concepto..., cit., p. 368.

130 SILVA SÁNCHEZ, Aproximación al Derecho..., cit., p. 279.

131 VOGEL, «Strafrechtsgüter und Rechtsgüterschutz durch Strafrecht im Spiegel der Rechtssprechung des Bundesverfassungsgerichts», StV, 2/96, p. 114. Y así parece que lo entiende también nuestro Tribunal Constitucional cuando en la STC de 2 de octubre de 1997 afirma: «En aplicación de las ideas fundamentales relativas al principio de proporcionalidad como criterio de enjuiciamiento del tratamiento de derechos fundamentales, hemos de reiterar que la relación final que guarde la magnitud de los beneficios obtenidos por la norma penal y la magnitud de pena...» 
derecho fundamental que la pena restringe y por ello cabe esperar que el Tribunal Constitucional puede llevar a cabo un control más intenso en esta sede ${ }^{132}$.

\section{Excurso: relación entre principio de proporcionalidad en sentido estricto y el principio de culpabilidad}

El principio de proporcionalidad se distingue del principio de culpabilidad ya que el primero afecta al injusto del hecho y el segundo a la atribuibilidad del hecho. En el momento de decidir sobre la proporcionalidad abstracta se trata de exigir proporcionalidad entre la gravedad del injusto y la de la pena con la que se le sanciona, y no se trata de exigir la atribuibilidad del injusto ${ }^{133}$. Además, el principio de culpabilidad se encuentra desvinculado de la finalidad ${ }^{134}$. Como acertadamente afirma MIR PUIG, el principio de culpabilidad, entendido en sus justos términos, no es suficiente para garantizar la necesaria proporcionalidad entre delito y pena. La culpabilidad nada dice acerca de la gravedad del injusto ni, por tanto, que la pena deba adecuarse a la misma ${ }^{135}$. Por consiguiente, en el momento legislativo, el principio de proporcionalidad y el de culpabilidad se pueden distinguir con cierta facilidad y se complementan. Por este motivo se rechaza la propuesta de aquellos autores que han defendido la sustitución del principio de culpabilidad por el de proporcionalidad ${ }^{136}$.

\section{Proporcionalidad concreta}

El otro ámbito en el que opera el principio de proporcionalidad en sentido estricto es el de aplicación por parte del Juez de la pena concreta al autor, hablándose en estos casos de proporcionalidad concreta: la pena aplicada al autor por el Juez ha de ser proporcionada a la gravedad del hecho cometido. Puesto que los principios de culpabilidad y proporcionalidad en sentido estricto son condensadores de algunos de los principios constitucionales del sistema penal en relación con un individuo concreto, en el momento judicial la relación de complementación entre ambos conceptos se intensifica y, por ello, en el momento de imponer la pena concreta al autor, el juez deberá atender tanto a la gravedad del injusto como

132 VOGEL, «Strafrecthsgüter und Rechtsgüterschutz...», StV, 2/96, p. 113.

133 MIR PUIG, Introducción a las bases..., cit., p. 158; OCTAVIO DE TOLEDO, Sobre el concepto..., cit., p. 367; GARCÍA-PABLOS, Derecho penal, Introducción, cit., p. 290. En la primera sentencia en la que el Tribunal Constitucional se pronunció sobre el principio de proporcionalidad (STC 65/1986), se señala que los criterios que utiliza el legislador al establecer en abstracto y con carácter general las penas correspondientes a las diversas conductas tipificadas como delitos, nada tienen que ver con la culpabilidad del autor concreto.

134 ZIPF, Introducción a la política criminal, Madrid, 1979, p. 56.

135 MIR PUIG, Derecho penal..., cit., p. 100.

136 Sobre esta propuesta, cfr. AGUADO CORREA, El principio constitucional..., cit., p. 256 y ss. 
a la culpabilidad concreta ${ }^{137}$. El grado del injusto y el de la culpabilidad no tienen por qué coincidir, de forma que en un hecho de elevada gravedad la culpabilidad puede ser escasa, y viceversa. Por consiguiente, siguiendo el método ofrecido por la teoría del delito, el juez tendrá que examinar en primer lugar la gravedad del injusto (principio de proporcionalidad) y en segundo lugar debe valorar en qué medida es atribuible a su autor (principio de culpabilidad) $)^{138}$.

Por último, destacar que el principio de proporcionalidad en sentido estricto, entendido como un principio constitucional que limita la prevención, se opone a ser vulnerado hacia arriba, pero no hacia abajo, es decir, constituye un límite máximo y no un límite mínimo ${ }^{139}$. El principio de proporcionalidad no impide que pueda disminuirse o incluso renunciarse a la pena por razones de prevención especial y, más concretamente, para impedir la desocialización o facilitar la socialización ${ }^{140}$. En estos casos en los que la finalidad de tutela de la pena puede quedar satisfecha bien con una pena menor o bien incluso sin pena alguna, «la proporcionalidad ha de ser entendida conforme a los requerimientos de la finalidad de tutela, que es el único objeto de ponderación, y no según la gravedad del, que es sólo un criterio genérico para efectuarla» ${ }^{141}$. En este sentido es en el que vendría a confluir la proporcionalidad en sentido estricto con la necesidad ${ }^{142}$.Por todo lo expuesto hasta ahora, y ante la insuficiencia del mecanismo previsto para asegurar la proporcionalidad concreta de una determinada pena, sería deseable, desde nuestro punto de vista, que se previese la posibilidad de que el Juez o Tribunal prescinda de la pena cuando resulte desproporcionada o innecesaria ${ }^{143}$.

137 En este sentido también se ha pronunciado ZIPF, Introducción a la política criminal, cit., p. 56. El Tribunal Constitucional, en la Sentencia de 22 de mayo de 1986 (FJ 3), afirma que la cuestión de la desproporción de la pena en el momento de su individualización se plantea en aquellos casos en los que la gravedad de la pena atribuida al condenado fuese superior a la legalmente imponible en relación a la gravedad de su culpabilidad.

138 MIR PUIG, Introducción a las bases..., cit., p. 164. Como señala este mismo autor, «Sobre el principio de culpabilidad como límite de la pena», en El Derecho penal en el Estado social y democrático de Derecho, Barcelona, 1994, pp. 178 y 179, el principio de culpabilidad no debe confundirse con la exigencia de cierta proporción entre la pena y la gravedad del delito, al no existir en nuestra legislación un precepto con el § 46 StGB en el que la imposición de la pena al individuo se fundamenta explícitamente en la culpabilidad del sujeto.

139 MIR PUIG, Introducción a las bases..., cit., pp. 104 y 105. Ésta es una de las diferencias que existen entre la postura sostenida por los defensores de la prevención general positiva fundamentadora y la que aquí sostenemos. Para aquéllos, no es posible imponer penas inferiores a lo «proporcionado» por los posibles efectos desestabilizadores que ello podría conllevar; cfr. SILVA SÁNCHEZ, Aproximación al Derecho..., cit., p. 259.

140 SILVA SÁNCHEZ, Aproximación al Derecho..., cit., p. 297.

$141 \mathrm{COBO} / \mathrm{VIVES}$, Derecho penal..., cit., pp. 80 y 81.

142 COBO/VIVES, Derecho penal..., cit., p. 81.

143 En este sentido también se pronuncia QUINTERO OLIVARES, Curso de Derecho..., cit., p. 542, para quien el marco penal debería incluir, junto al límite mínimo, la posibilidad de no imponer pena alguna para los casos de desproporción o falta de sentido. 


\section{Delitos de peligro abstracto}

\section{V.1. Delimitación conceptual de los delitos de peligro abstracto}

La ley tan sólo contiene tipos delictivos, no contiene ni delitos de lesión ni delitos de peligro, procediendo su distinción por parte de la doctrina de su puesta en relación con los bienes jurídicos protegidos ${ }^{144}$. Si bien la mayoría de la doctrina lleva a cabo esta distinción acudiendo al criterio de la intensidad del ataque al bien jurídico ${ }^{145}$, no obstante, hay autores que distinguen los delitos de lesión de los delitos de peligro (concreto) según la intensidad del menoscabo del objeto de la acción ${ }^{146}$.

Dentro de los delitos de peligro es usual la distinción entre delitos de peligro abstracto y delitos de peligro concreto e incluso, algunos autores reconocen una tercera categoría denominada delitos de peligro abstracto-concreto. Los delitos de peligro concreto se diferencian en esencia de los delitos de lesión, no en virtud de los distintos criterios de imputación, sino que en vez de un resultado de lesión se da un resultado de peligro concreto. También hay autores que admiten la existencia de una categoría intermedia entre los delitos de peligro abstracto y los delitos de peligro concreto. La nomenclatura es variada y también varían las características y los delitos incluidos en esta categoría por parte de los distintos autores. En Alemania, SCHRÖDER habla de los delitos de peligro abstracto-concreto ${ }^{147}$, mientras que HOYER habla de delitos de aptitud ${ }^{148}$. Lo cierto es que esta postura no cuenta con muchos adeptos, señalando acertadamente la mayoría de la doctrina, tal y como en un principio hizo GALLAS ${ }^{149}$, que algunos de estos delitos que se han incluido en una categoría intermedia pueden ser considerados como delitos de peligro concreto, en tanto que la mayoría de ellos no son sino delitos de peligro abstracto.

Por lo que respecta a los delitos de peligro abstracto, es usual que la doctrina los defina de forma negativa a través de su confrontación con los delitos de peligro concreto y de

144 BOHNERT, «Die Abstraktheit der abstrakten Gefährdungsdelikte», JuS, 1984, p. 184.

145 La mayoría de la doctrina lleva a cabo la distinción entre delitos de lesión y de peligro atendiendo a la intensidad del ataque al bien jurídico, cfr. referencias doctrinales en AGUADO CORREA, El principio constitucional..., cit., p. 271, n.p.p. 14 .

146 Hay autores como JESCHECK, Tratado de Derecho penal, $4 .^{a}$ ed., pp. 234 y ss., que distinguen entre delitos de lesión y delitos de peligro (concreto) según la intensidad del menoscabo del objeto de la acción; ROXIN, Strafrecht. Allgemeiner Teil, cit., § 10/122 (273); JAKOBS, Strafrecht. Allgemeiner Teil, Die Grundlagen und die Zurechnungslehre, 2. ${ }^{a}$ Auf., Berlin, 1991, § 6/78.

147 SCHRÖDER, «Abstrakt-konkrete Gefährdungsdelikte?», JZ1967, pp. 522 y ss. Esta denominación ya fue utilizada por HERRMANN, Zum Begriff der Gefahr, insbesondere der Gemeingefahr im deutschen Strafrecht, Düsseldorf, 1939, pp. 20 y ss.

148 HOYER, Die Eignungsdelikte, Berlín, 1987, passim. En esta categoría incluye este autor aquellos delitos en los que, sin exigirse un resultado, tampoco se renuncia de una forma completa a la referencia a la víctima en la norma.

149 GALLAS, en su artículo «Abstrakte und konkrete Gefährdung», en Festschrift für Heinitz, Berlín, 1972, p. 171, analiza la propuesta realizada en su día por SCHRÖDER. 
lesión, como aquellos en los que no se exige ni la puesta en peligro en concreto ni la lesión del bien jurídico protegido. Un exponente claro de esta tendencia a la configuración de los delitos de peligro abstracto de forma negativa, lo encontramos en la definición que ofrece HORN de los delitos de peligro abstracto: «El concepto de delitos de peligro abstracto tan sólo indica algo negativo: que el legislador no ha establecido como elemento del tipo ni la lesión ni la puesta en peligro concreto del bien jurídico protegido por la norma» ${ }^{150}$. Pero qué caracteriza positivamente a los delitos de peligro abstracto es una cuestión que está abierta y sin una respuesta única. Ello se debe, en parte, a que de la configuración legal de los delitos de peligro abstracto no se extrae ningún elemento común a todos ellos que haga posible el reconocimiento de cuándo estamos ante un delito de peligro abstracto, y más aún, si tenemos en cuenta que no todos los tipos recogen expresamente los bienes protegidos por los mismos ${ }^{151}$.

Si nos preguntamos por la justificación de la denominación de estos delitos como delitos de peligro abstracto, así como por el motivo de su incriminación, podemos encontrar dos posturas que intentan dar respuesta a esta cuestión y que ya fueron recogidas por BINDING $^{152}$ : la teoría de la peligrosidad general o teoría de la peligrosidad o del peligro como motivo y, por otra parte, la teoría de la peligrosidad abstracta o teoría de la presunción ${ }^{153}$. Común a ambas teorías es la absoluta falta de referencia al peligro en el caso concreto, ignorándose por completo los problemas que plantean aquellos supuestos en los que, a pesar de haberse realizado la acción generalmente peligrosa, no se origina peligro alguno para el bien jurídico protegido debido a la concurrencia de determinadas circunstancias. Y es esta falta de referencia al caso concreto la que ha originado las más intensas críticas de la doctrina a la categoría de los delitos de peligro abstracto, y la que hace necesario replantearse la misma teniendo en cuenta los principios constitucionales que afectan al Derecho penal.

150 HORN, en Systematischer Kommentar..., cit., vor $§ 306$, Nm. 15. También GRAUL, Abstrakte Gefährdungsdelikte und Präsumtionen im Strafrecht, Berlin, 1991, pp. 108 y 109, da una definición casi coincidente de delitos de peligro abstracto, si bien se diferencia de la ofrecida por HORN, como ella misma pone de manifiesto, p. 141, en que este autor concede un carácter meramente negativo a esta definición; por contra, ella, en tanto que en los delitos de peligro abstracto se trata de proteger bienes jurídicos, ve un factor (concepto) positivo determinante.

151 Si consideramos, como hace la mayoría de la doctrina, que los denominados delitos de aptitud son delitos de peligro abstracto, en estos casos sí que en el tipo se hace referencia expresa a los bienes jurídicos protegidos.

152 BINDING, Die Normen und ihre Übertretung I, 2. ${ }^{\text {a }}, 1890$, pp. 379 y 380.

153 Cfr. sobre los postulados de estas teorías y sus partidarios, AGUADO CORREA, El principio constitucional..., cit., pp. . 273 y ss. 


\section{V.2. Compatibilidad de los delitos de peligro abstracto con el principio de proporcionalidad en sentido amplio}

En las páginas que siguen nos vamos a ocupar del respeto por parte de los delitos de peligro abstracto del principio constitucional de proporcionalidad en sentido amplio. Una vez que hemos constatado que nos encontramos ante un principio constitucional que limita el ius puniendi consagrado en los artículos 1.1, 9.3 y 10.1 CP, que tiene una especial virtualidad y se aplica normalmente en el ámbito de los derechos fundamentales, y que en el Derecho penal consideramos que se descompone en el principio de aptitud, en el de necesidad, que a su vez se concreta en el de protección exclusiva de bienes jurídicos y en el de intervención mínima y, en último lugar, en el principio de proporcionalidad en sentido estricto, pasamos a estudiar si la técnica utilizada en los denominados delitos de peligro abstracto vulnera alguno o algunos de estos principios.

El principal problema que plantean los denominados delitos de peligro abstracto se debe, fundamentalmente, a la amplitud con la que son redactados por el legislador. Por una parte, en el tipo se incluyen aquellas acciones que pese a ser subsumibles formalmente en el comportamiento descrito por la norma, en el caso concreto no son idóneas para menoscabar el bien jurídico protegido. Esta realidad y los problemas que de ella se derivan ha sido ampliamente discutida por la doctrina, tanto española como extranjera, y se han buscado distintas soluciones dogmáticas. Además, la importancia de este problema se debe a que no sólo posee dimensiones dogmáticas, sino que también adquiere dimensiones constitucionales, siempre que se pongan en relación estos delitos con el principio de exclusiva protección de bienes jurídicos y con el principio de ofensividad, los cuales, como ya hemos visto, forman parte del principio de proporcionalidad en sentido amplio.

Sin embargo, no se acaban en la compatibilidad de los delitos de peligro abstracto con el principio de exclusiva protección de bienes jurídicos y de ofensividad, los problemas con relevancia constitucional que plantean, desde nuestro punto de vista, aquéllos. Los supuestos en los que se pone en peligro el bien jurídico de manera insignificante pueden plantear problemas puestos en relación con el principio constitucional de proporcionalidad en sentido estricto. Se debe a que los delitos contra bienes jurídicos supraindividuales se suelen configurar como delitos de peligro abstracto, no exigiéndose, pues, ni la lesión ni la puesta en peligro concreto del bien jurídico en cuestión, debido a la imposibilidad de su comprobación. Como señalan algunos autores, el medio para una protección jurídico-penal eficaz de los bienes jurídicos supraindividuales y los objetos de ataque, en cuanto objetos 
Principio de proporcionalidad y delitos de peligro abstracto

TERESA AGUADO-CORREA

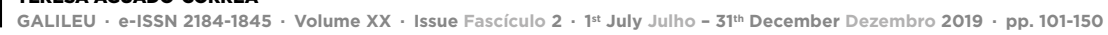


ideales, consistiría en los delitos de peligro abstracto ${ }^{154}$, con el «peligro» que ello conlleva de ampliar demasiado el ámbito del Derecho penal a comportamientos en los que falta el merecimiento o la necesidad de pena, o en los que, dándose ambos requisitos, falta la necesaria proporción entre la entidad del delito y la entidad de la pena.

En el estudio que realizamos a continuación, lo que pretendemos poner de relieve es hasta qué punto el principio de proporcionalidad en sentido amplio se comporta como un verdadero límite al ius puniendi $i^{155} \mathrm{y}$ hasta qué punto, en caso de que no sea respetado por el legislador cuando utiliza la técnica del peligro abstracto, puede ser objeto de control por parte del Tribunal Constitucional su vulneración, puesto que nos encontramos ante un principio constitucional. No tratamos de pronunciarnos sobre la vulneración o no de este principio por parte del legislador cada vez que utiliza a lo largo del Código Penal esta técnica, sino de realizar una serie de consideraciones generales. Somos conscientes de que cualquier intento de dar una solución global y válida sobre la legitimación y validez de todos los delitos de peligro abstracto está abocada al fracaso y se requiere un estudio detallado de cada grupo de delitos, pero ello excede de las pretensiones de nuestro trabajo.

\section{V.2. A. Principio de idoneidad y delitos de peligro abstracto}

\section{Idoneidad de los delitos de peligro abstracto para la protección de bienes jurídicos.}

Los delitos de peligro abstracto encuentran su justificación en la necesidad de una tutela más acabada y eficaz de los bienes jurídicos que se consideran esenciales y, fundamentalmente, de los denominados bienes jurídicos colectivos ${ }^{156}$. Sin embargo, como ya dijimos cuando tratamos el principio idoneidad del Derecho penal, no todos los bienes jurídicos son aptos o idóneos para ser protegidos penalmente. De ello podemos concluir que no serán idóneos para proteger bienes jurídicos aquellos delitos de peligro abstracto que consisten en la violación de reglas ético-sociales o ético-religiosas, al no tipificar acciones que supongan peligro alguno para un bien digno de protección jurídico-penal157.

154 OTTO, Grundkurs Strafrecht. Die einzelnen Delikte, $4 .^{\text {a }}$ ed., Berlín 1995, p. 283; TIEDEMANN, Wirtschaftsstrafrecht und Wirtschaftskriminalität, Band 1, Hamburg, 1976, pp. 41 y ss.

155 En este análisis tendremos muy presente lo afirmado por el Tribunal Constitucional alemán en la Sentencia de 9 de marzo de 1994 (BVerfGE 90, 145), conocida popularmente como la sentencia del cannabis o del hashish. En ella se pronunció sobre la posible vulneración del principio de proporcionalidad por parte de los preceptos de la Betäubungsmittelgesetz (BtMG), que amenazan con pena el tráfico ilegal de drogas o la posesión de las mismas cuando se trata de productos derivados del cannabis; preceptos, en los que el legislador había acudido a la técnica del peligro abstracto..

156 MAQUEDA ABREU, «La idea de peligro en el moderno Derecho penal. Algunas reflexiones a propósito del Proyecto de Código Penal de 1992», Actualidad Penal, 1994, p. 487.

157 En este sentido FIANDACA, «La tipizzazione del pericolo», Dei Delitti e delle Pene, 1984, p. 460, cuestiona la admisibilidad constitucional y político-criminal de la protección a través de la técnica de los delitos de 
Por otra parte, se puede afirmar que un tipo penal es apto para la protección de un bien jurídico siempre y cuando las acciones típicas por él descritas afecten de algún modo al bien jurídico. De ello se deduce que aquel tipo penal en el que se tipifique acciones que de ningún modo afectan al bien jurídico que se pretende proteger a través del mismo, será inidóneo, puesto que la protección del bien jurídico no puede tener lugar a través de dicha prohibición. Al ser inidóneo para la protección del bien jurídico, dicho tipo se puede considerar inconstitucional por ser contrario al principio de proporcionalidad en sentido amplio. Por lo tanto, no son idóneos los delitos de peligro abstracto para la protección del bien jurídico cuando a través de los mismos se incriminan meras infracciones administrativas que no suponen peligro alguno para el respectivo bien jurídico ${ }^{158}$. Lo más inquietante es que este problema, la criminalización de meros injustos administrativos, está adquiriendo de nuevo importancia en los ordenamientos jurídicos.

Pero no podemos desconocer que en los casos en los que el bien jurídico puede ser afectado a través de una gran variedad de conductas, a veces es difícil establecer una línea de separación entre las conductas inofensivas y aquellas otras conductas que afectan al bien jurídico. Y es en los denominados delitos de peligro abstracto, a través de los cuales se incriminan aquellas acciones general y abstractamente peligrosas para el bien jurídico, donde resulta bastante difícil para el legislador separar claramente a la hora de tipificar, aquellos comportamientos inofensivos de los que realmente suponen un peligro abstracto para el bien jurídico protegido. En aquellos supuestos en los que encuentra dificultades para esta delimitación, y debido a la importancia del bien jurídico en juego, el legislador considera más idóneo para su protección acudir a la prohibición de un comportamiento generalmente peligroso para el bien jurídico, sin que de esta manera se privilegien los comportamientos menos peligrosos. Desde el punto de vista de la idoneidad, no hay nada que objetar a esta forma de tipificación siempre que se trate de un comportamiento generalmente peligroso, no estando justificada, por el contrario, la conminación penal de comportamientos que excepcionalmente pueden resultar peligrosos para el bien jurídico. Queda justificada, por este motivo, la idoneidad de esta técnica en el delito de tráfico de drogas o en el supuesto del delito de conducción bajo la influencia de bebidas alcohólicas, drogas tóxicas o estupefacientes.

En el seno de la doctrina, un considerable número de autores afirma que la utilización de la técnica de los delitos de peligro abstracto es la más idónea/eficaz para protección de

peligro abstracto de objetos tales como el pudor público. TORÍO LÓPEZ, «Los delitos del peligro hipotético (Contribución al estudio diferencial de los delitos de peligro abstracto)», ADPCP, 1981, pp. 827 y ss., distingue tres grupos de delitos de peligro abstracto, estando los primeros constituidos por los delitos que consisten en la violación de reglas ético-sociales o ético-religiosas.

158 Es el segundo grupo de delitos dentro de los de peligro abstracto que distingue TORÍO LÓPEZ. 
los bienes jurídicos colectivos ${ }^{159}$, aun cuando también hay quien se plantea hasta qué punto es correcto en estos casos hablar de delitos de peligro ${ }^{160}$ y quien considera preferible para su protección la configuración del delito como de lesión o incluso de peligro concreto ${ }^{161}$.

Lo cierto es que la opción adoptada por el legislador cuando se trata de proteger bienes jurídicos colectivos es la técnica del peligro abstracto, ya que suele acudir a la prohibición de acciones generalmente peligrosas para los bienes jurídicos fundamentalmente para evitar los problemas de prueba que se plantearían si se exigiese la puesta en peligro concreto o la lesión de estos bienes jurídicos colectivos ${ }^{162}$. Se trata de ámbitos en los que es muy difícil tipificar la producción de resultados lesivos o de puesta en peligro concreto, al exigir los delitos de resultado el conocimiento y comprobación del nexo causal entre la acción individual y el resultado, siendo más fácil la determinación de la aptitud general de determinados comportamientos para poner en peligro el bien jurídico protegido ${ }^{163}$.

Por otra parte, normalmente la prohibición de las conductas que pongan en peligro o lesionen el bien jurídico no es suficiente para su protección, ya que en general los ataques a estos bienes jurídicos tienen lugar a través de acciones masas cuya peligrosidad indivi-

159 Con carácter general consideran que los delitos de peligro abstracto son los más eficaces para la protección de los bienes jurídicos colectivos, entre otros, FIANDACA, «La tipizzazione del pericolo», Dei Delliti e delle Pene, 1984, pp. 454 y ss; MUÑOZ CONDE, «El “moderno" Derecho penal en el nuevo Código Penal, principios y tendencias», La Ley, 1996, p. 1340; VALLE MUÑIZ, en Comentarios al nuevo..., cit., p. 1329. Por el contrario, MÉNDEZ RODRÍGUEZ, Los delitos de peligro y sus técnicas de tipificación, Madrid, 1993, pp. 160 y 161, afirma que es erróneo estimar que lo más eficaz para la protección de los bienes jurídicos colectivos es la creación de delitos de peligro abstracto porque la lesión no es determinable. Sobre los autores que consideran que en el ámbito del Derecho penal económico que la técnica de protección más idónea es la del peligro abstracto, debido al carácter ideal tanto del bien jurídico como del objeto de ataque, vid. AGUADO CORREA, El principio constitucional..., cit., p. 283, n.p.p. 66.

160 TIEDEMANN, Poder económico y delito..., cit., p. 36; MAQUEDA ABREU, «La idea de peligro...», Actualidad Penal, núm. 26 (1994), p. 492; GARCÍA RIVAS, Contribución al estudio de peligro y aplicación a los delitos contra la salud pública y el medio ambiente, Albacete, 1995, p. 148; TERRADILLOS BASOCO, Derecho penal de la empresa, Madrid, 1995, p. 57.

161 En este sentido se manifiestan BUSTOS RAMÍREZ, «Los bienes jurídicos colectivos», RFDUCM, núm. 11 (1986), p. 160; MÉNDEZ RODRÍGUEZ, Los delitos de peligro..., cit., p. 161; TERRADILLOS BASOCO, Derecho penal de la empresa, cit., p. 57.

162 WEBER, «Die Vorverlegung des Strafrechtsschutzes durch Gefährdungs - und Unternehmensdelikte», ZStW, Beiheft, 1987, pp. 24 y ss. WEIGEND, «Bewältigung von Beweisschwierigkeiten...?, Festschrift für Otto Triffterer, 1996, p. 695 y ss., sostiene que el legislador penal tiene varias formas de evitar las dificultades de prueba que se le puedan presentar, soluciones que redundan en una ampliación material del Derecho penal. En el XIII Congreso de la Asociación Internacional de Derecho Penal sobre «El concepto y los principios fundamentales del Derecho penal económico y de la empresa» (El Cairo, 1984) se admite la validez de los delitos de peligro abstracto para la lucha contra la delincuencia económica y de la empresa, siempre que la conducta que se prohíbe se determine con claridad y los bienes jurídicos también se encuentren determinados. Por contra, niegan la justificación de los delitos de peligro abstracto cuando exclusivamente se pretenda facilitar la prueba de los delitos.

163 Como acertadamente pone de manifiesto TERRADILLOS BASOCO, «Protección penal del medio ambiente en el nuevo Código Penal español. Luces y sombras», Estudios Penales y Criminológicos, XIX (1996), p. 317, el argumento de la dificultad de la imputación objetiva del resultado presente en el origen de la mayoría de los delitos de peligro abstracto y que exonera al juez de la obligación de verificar la corrección del juicio de peligro elaborado por el legislador en el tipo, se puede replicar afirmando que mayores son las dificultades con las que topa el legislador que tiene que actuar sobre supuestos más generales. 
dualmente considerada es insignificante, pero cuya repetición puede menoscabar el bien jurídico. Es lo que sucede, por ejemplo, en los delitos contra el medio ambiente ${ }^{164}$, en los que resulta particularmente difícil especificar tanto cuantitativa como cualitativamente los efectos que una conducta particular ocasiona sobre el medio ambiente y en los que la afectación del bien jurídico tiene lugar por la repetición generalizada y frecuente de la conducta $^{165}$. Con el mismo problema que en los delitos contra el medio ambiente se encuentra el legislador, según un sector de la doctrina, cuando se trata de tipificar los ataques a los bienes jurídicos colectivos que se refieren a estructuras o instituciones básicas en el funcionamiento del Estado o del sistema social (contra la Administración de Justicia, contra la Administración Pública, contra el orden socio-económico): la tipificación de una lesión o un peligro concreto es difícil porque el menoscabo del bien jurídico se produce por la reiteración generalizada de conductas que no respetan las reglas básicas que permiten asegurar el sistema y su funcionamiento, más que por una conducta concreta ${ }^{166}$. Y para soslayar este problema, el legislador decide acudir a la técnica de tutela que considera más eficaz: los delitos de peligro abstracto. Parte de la doctrina habla en estos casos de «delitos con bien jurídico intermedio espiritualizado», adoptando la denominación propuesta por SCHÜNE$\mathrm{MANN}^{167}$, quien incluía en esta categoría delitos en los que se sostiene que la lesión del bien jurídico intermedio representa, por sí misma, un injusto ${ }^{168}$.

164 Cfr. AGUADO CORREA, El principio constitucional..., cit., p. 286, n.p.p. 71, sobre el gran número de autores que consideran preferible la tipificación como delito de peligro abstracto en materia medio ambiental. Contrario a la utilización de tipos de peligro en materia medio-ambiental se muestra PRATS CANUT en Comentarios al Nuevo..., cit., pp. 1518 y 1519.

165 KLEINE-COSACK, Kausalitätsprobleme im Umweltstrafrecht, Berlín, 1988, pp. 77 y 78.

166 En este sentido LOOS, «Zum "Rechtsgut" der Bestechungsdelikte», Festschrift für Welzel, 1974, 879 y ss.; ANGIONI, Contenuto e funzioni..., cit., pp. 63 y ss.; FIANDACA, «La tipizzazione del pericolo», Dei Delitti e delle Pene, 1984, 456; GRASSHOF, BVerfGE 90, 145 (204), y en el seno de nuestra doctrina RODRÍGUEZ MONTAÑÉS, Delitos de peligro..., cit., p. 301.

167 Este autor («Moderne Tendenzen in der Dogmatik der Fahrlässigkeits - und Gefährdungsdelikte», JA, 1975, p. 798) distingue tres categorías dentro de los delitos de peligro abstracto. La primera de ellas viene constituida por los «delitos con bien jurídico intermedio espiritualizado» («Delikte mit einem vergeistigten Zwischenrechtsgut»); la segunda, por las acciones masas, y la tercera, por aquellos delitos en los que se tipifica una tentativa imprudente que se caracteriza por la «infracción del cuidado subjetivo». Esto ocurriría, según este autor, en delitos tales como el falso testimonio, el cohecho y el delito de falsedad documental, aun cuando en la doctrina es más discutida la consideración de este último como un delito de peligro abstracto. Entre otros, han adoptado esta denominación WOLTER, Objektive und personale Zurechnung von Verhalten, Gefahr und Verletzung in einem funktionalen Strafrechtssystem, Berlin, 1981, pp. 328 y ss.; ROXIN, Strafrecht. Allgemeiner Teil, cit., 11/126; RODRÍGUEZ MONTAÑÉS, Delitos de peligro, dolo e imprudencia, Madrid, 1994, p. 300. JAKOBS, Strafrecht. Allgemeiner Teil, cit., 6/88, si bien no utiliza esta denominación, llega a la misma conclusión que SCHÜNEMANN, según señala el propio autor, de que cuando un delito es de peligro abstracto ello no impide que su resultado lesione un objeto que representa al bien en un plano menos abstracto.

168 ROXIN, Strafrecht. Allgemeiner Teil, cit., § 11/126, considera que el desvalor de la acción en estos delitos fundamenta por sí solo la punibilidad, puesto que el bien jurídico correspondiente no ha de ser puesto en peligro en el caso concreto a través de la acción subsumible en el tipo. 
En el seno de la doctrina española sostiene que la técnica del peligro abstracto es la más idónea para proteger los «delitos con bien jurídico intermedio con función representativa», siguiendo las propuestas de los autores alemanes, RODRÍGUEZ MONTAÑ́́S ${ }^{169}$. Para esta autora, esta técnica estaría justificada siempre y cuando el bien que se trata de proteger tenga la suficiente entidad para ser merecedor de tutela penal, pues aquí no se trata de anticipar la protección de bienes jurídicos esenciales. Dentro de esta categoría incluye delitos tales como el falso testimonio ${ }^{170}$, el cohecho pasivo, malversación de caudales públicos, tráfico de influencias... ${ }^{171}$. Asimismo, esta autora sostiene que estas consideraciones sobre los «delitos con bien jurídico intermedio con función representativa» son extensibles a los delitos contra el medio ambiente, en el caso de que se configuren como delitos de peligro abstracto, o bien a los delitos monetarios o a los delitos contra la Hacienda Pública, delitos a través de los cuales se protegen mediatamente estructuras básicas de la vida económica ${ }^{172}$.

Si bien no discutimos que entre los delitos incluidos en la categoría de los denominados delitos «con bien jurídico espiritualizado» existen verdaderos delitos de peligro abstracto, no creemos que todos los que incluye esta autora en esta categoría quepa considerarlos como delitos de peligro abstracto, tal y como sucede, por ejemplo, con el delito de cohecho pasivo propio $^{173}$. No creemos que, tal y como afirma RODRÍGUEZ MONTAÑÉS, el injusto de

169 RODRÍGUEZ MONTAÑÉS, Delitos de peligro..., cit., pp. 300 y ss. Para esta autora, a través de estos delitos se están protegiendo «bienes jurídicos supraindividuales de carácter inmaterial a través de bienes u objetos intermedios con una función representativa, en cuya lesión reiterada y generalizada radica la "abstracta peligrosidad" de la conducta típica, sin que ello tenga relevancia directa ni en el tipo objetivo ni en el tipo subjetivo». Y por ello se considera que la vía idónea para la protección de estos bienes jurídicos es la técnica del peligro abstracto. Esta autora tan sólo admite la atipicidad de la conducta cuando se trate de «ataques mínimos», en virtud del principio de insignificancia. Como ella misma reconoce, los autores alemanes que admiten esta categoría de delitos de peligro abstracto también admiten como único correctivo típico los «ataques mínimos», pero sin hacer mención al principio de insignificancia. No comparte la división que propone esta autora entre bienes jurídicos individuales o individualizables y bienes jurídicos supraindividuales o institucionalizados MUÑOZ CONDE, en HASSEMER/MUÑOZ CONDE, La responsabilidad por el producto en Derecho penal, Valencia, 1995, p. 60, para quien en última instancia la razón de éstos es la protección de bienes jurídicos individuales.

170 Para esta autora (Delitos de peligro..., cit., p. 302), el bien jurídico institucionalizado mediatamente protegido o «representado» por este delito, tal y como venía configurado en el CP anterior (arts. 326 y ss.), regulación que en lo básico coincide con la del CP 1995, es la correcta Administración de Justicia. Además, afirma que el tipo se conforma con la lesión de «la veracidad de las declaraciones procesales» («objeto representativo»).

171 En todos estos delitos el bien jurídico inmaterial mediatamente protegido, en opinión de RODRÍGUEZ MONTAÑÉS, Delitos de peligro..., cit., p. 303, es el correcto funcionamiento de la Administración pública. Sostiene, además, que este bien jurídico no es susceptible de ser menoscabado a través de conductas individualmente consideradas, pero sí si se repiten y generalizan.

172 RODRÍGUEZ MONTAÑÉS, Delitos depeligro..., cit., pp. 303 y 304,n.p.p. 347, considera que si bien el incumplimiento de los deberes tributarios no supone individualmente una lesión o puesta en peligro de la economía estatal, ello podría tener lugar a través de la generalización y repetición de tales conductas.

173 Si consideramos, como acertadamente hace VALEIJE ÁLVAREZ, «Consideraciones sobre el bien jurídico protegido en el delito de cohecho», EPC, XVIII (1995), p. 354, que nociones como la de «buen funcionamiento», «pureza» o «prestigio» no satisfacen los aspectos fundamentales que el concepto de bien jurídico exige al ordenamiento jurídico y que el bien jurídico protegido en el delito de cohecho pasivo es el principio de imparcialidad de la actuación administrativa entendido como medio para alcanzar una satisfacción igual y 
estos delitos pueda basarse en la mera infracción de deberes y que se niegue toda referencia al bien jurídico que de forma «mediata» se protege y que, según esta autora, es merecedor de tutela penal. En estos delitos no hay más que un bien jurídico y la antijuricidad material de todo delito se construye en base al mismo. Por otro lado, el que parte de la doctrina considere que la forma más idónea de proteger determinados bienes jurídicos es la técnica de peligro abstracto no quiere decir que el legislador haya hecho uso de esta técnica para protegerlos, pudiendo haber configurado un delito de lesión o de peligro concreto. Creemos que esta autora no ha tenido en cuenta que en cada uno de los delitos que enumera se protege un bien jurídico más concreto que el del correcto funcionamiento de la Administración Pública, en cuya lesión o puesta en peligro concreto se agota el injusto material del delito. Hay determinados supuestos en los que se pueden identificar bienes jurídicos intermedios que gozan de autonomía propia, a pesar de ser instrumentales respecto de los bienes jurídicos representados ${ }^{174}$. Tampoco hay que confundir, como ya pusimos de manifiesto, el bien jurídico protegido con la ratio legis. Puede ser que el legislador a través de estas incriminaciones pretenda el correcto funcionamiento de la Administración Pública, pero no por ello ha de erigirse éste directamente en bien jurídico. El bien jurídico ha de ser lesionado o puesto en peligro; la finalidad perseguida por el legislador, sin embargo, no tiene por qué cumplirse. Por otra parte, en la reiteración generalizada no puede residir la abstracta peligrosidad de la acción, puesto que si ello fuese así se estaría culpando al autor por las demás acciones que contribuyen a la puesta en peligro abstracto del bien jurídico y no por su acción. Otro de los ámbitos en los que ha sido tradicional el uso por parte del legislador de la técnica de los delitos de peligro, y más concretamente de la técnica de los delitos de peligro hipotético y de peligro abstracto en sentido tradicional, es el ámbito de los delitos contra la salud pública. Sobre el bien jurídico protegido en estos delitos se ha escrito mucho en nuestro país, y en este momento no nos interesa reproducir la polémica doctrinal que sobre el mismo ha existido, pero sí diremos que consideramos que la salud pública es un bien jurídico colectivo merecedor, necesitado y capaz de protección penal, y que posee autonomía frente al bien jurídico salud individual, sin perjuicio de que uno de los bienes jurídicos individuales sea mediatamente protegido ${ }^{175}$.

objetiva de los intereses generales, cabría concluir que en el delito de cohecho pasivo propio (arts. 419, 420, 421) nos encontramos ante delitos de lesión.

174 TERRADILLOS, Derecho penal de la empresa, cit., p. 57.

175 En este sentido, HASSEMER/MUÑOZ CONDE, La responsabilidad por el producto..., cit., pp. 56 y 57; CORCOY BIDASOLO, «Resultado de muerte y lesiones como consecuencia de un delito contra la salud pública» (comentario a la STS de 22 de abril de 1987; ponente: Marino Barbero Santos), ADPCP, 1989, 337 y ss. GARCÍA ALBERO, en Comentarios al Nuevo..., cit., p. 1603.También hay un sector de la doctrina para el cual la salud pública no constituye un bien jurídico autónomo, sino que lo que se protege a través de estos tipos penales no es más que la salud individual de cada uno de los consumidores y del grupo social que todos ellos forman. En este 


\section{Control constitucional del respeto del principio de idoneidad}

El legislador cree que la técnica más idónea para la protección de determinados bienes jurídicos, y fundamentalmente de bienes jurídicos colectivos, es la utilización de la técnica de los delitos de peligro abstracto, valiéndose cada vez con más frecuencia de la técnica de los delitos de peligro hipotético en los que el legislador incluye elementos normativos de aptitud en el tipo, sin que por ello dejen de ser delitos de peligro abstracto, debiendo comprobar el juez en el caso concreto la aptitud lesiva de la conducta. En algunos supuestos, no compartimos la decisión adoptada por legislador: en unos casos porque creemos que hubiese sido más idóneo para la protección del bien jurídico correspondiente el uso de la técnica del delito de peligro hipotético en vez de la técnica del peligro concreto; en otros casos, no consideramos idónea la utilización de la técnica de los delitos de peligro abstracto por parte del legislador porque a través de los mismos se trata de incriminar meros injustos administrativos, meros incumplimientos de deberes en los que no estamos ante comportamientos generalmente peligrosos, sino que sólo excepcionalmente pueden resultar peligrosos para el bien jurídico.

No tiene sentido que nos planteemos aquí la idoneidad o no de todos y cada uno de los delitos que nuestro legislador ha configurado como delitos de peligro abstracto, porque en este trabajo queremos hacer hincapié en la virtualidad del principio de prohibición en sentido amplio como límite del ius puniendi y el control del cumplimiento de este principio constitucional. Lo cierto es que el legislador tiene un amplio ámbito de decisión en el momento de elegir el medio más idóneo para alcanzar el fin pretendido y el Tribunal Constitucional en el control de esta decisión muy poco tiene que decir.

Como muestra de lo que acabamos de afirmar sobre el ámbito de decisión del legislador, tenemos tanto el pronunciamiento del Tribunal Constitucional alemán sobre los preceptos de la BtMG como algún pronunciamiento de nuestro Tribunal Constitucional (SSTC 161/1997 y 136/1999). En Alemania, el juicio de aptitud no es un requisito difícil de cumplir, y ello no sólo por la prerrogativa de evaluación y espacio de decisión que se le concede al legislador penal, sino también debido a que el BVerfG únicamente reconoce la inconstitucionalidad de aquellas leyes que manifiestamente no son aptas para alcanzar el fin pretendido. Para este Tribunal, no constituye obstáculo alguno, en orden a confirmar la idoneidad de una ley, el escaso número de los casos perseguidos o sentenciados o el elevado número de la cifra oscura, ya que en estos casos el BVerfGE enfatiza el efecto de prevención

sentido, se pronuncia RODRÍGUEZ MONTAÑÉS, Delitos de peligro..., cit., pp. 305 y ss., la misma en RODRÍGUEZ MONTAÑÉS/PAREDES CASTAÑÓN, El caso de la colza: responsabilidad penal por productos adulterados o defectuosos, Valencia, 1995, pp. 195 y 196. 
general ${ }^{176}$. Y es el argumento al que recurre el BVerfG cuando se trata de justificar el adelantamiento de la protección penal a través de los delitos de peligro abstracto: el efecto de prevención general de estos tipos. Afirma que, debido a motivos de prevención general, está justificado que los tipos que contemplan la prohibición de traficar con productos derivados del cannabis amplíen la protección abarcando todos los comportamientos que «son generalmente aptos» para producir los peligros descritos ${ }^{177}$. El BVerfG parte de la premisa de que el fin de la Ley sobre estupefacientes (BtMG) es la de proteger la salud tanto de los individuos como de la colectividad frente a los peligros que se derivan de los estupefacientes y preservar a la sociedad, ante todo a la juventud, de la dependencia de las drogas ${ }^{178}$. A este fin sirven los preceptos de la BtMG y, para alcanzar este fin, el legislador no sólo incrimina aquellos comportamientos que son peligrosos para el individuo, sino que pretende la organización de la vida comunitaria (sozialen Zusammenlebens), de tal manera que quede libre de todos los efectos perjudiciales socialmente que se derivan del tráfico con estupefacientes. Además, el BVerfG considera que este fin que se pretendía cuando fue promulgada la BtMG se ha ampliado entre tanto de una forma considerable con los distintos convenios internacionales y, en especial, a través de la Convención de las Naciones Unidas sobre tráfico de estupefacientes y sustancias psicotrópicas de $1988^{179}$, siendo la BtMG «a la luz de esta Convención la contribución de Alemania al control internacional de estupefacientes y sustancias psicotrópicas, al control del comercio con estos estupefacientes y así como a la lucha del mercado ilegal de drogas y de las organizaciones criminales que en él participan» ${ }^{180}$.

En principio nada hay que objetar al hecho de que el legislador considere que la intimidación de todos los potenciales consumidores a través de la conminación legal sea más idónea/eficaz que la impunidad de estos comportamientos. El propio BVerfG reconoce, tras la exposición de una serie de datos sobre los efectos de los productos derivados del cannabis, que a pesar de que los peligros derivados de los mismos son menores que los que el legislador había considerado a la hora de promulgar la ley, todavía existen y no carecen de importancia. El legislador parte de que la totalidad del tráfico con productos derivados del cannabis, excepto el consumo, requiere un control estatal debido a los peligros que se derivan de la droga y del tráfico de drogas, tanto para el individuo como para la colectividad, y

176 BVerfGE 39, 1 (57); VOGEL, «Strafrechtsgüterschutz und Rechtsgüterschutz...», StV, 2/96, p. 113.

177 BVerfGE 90, 145 (184). Los peligros que según el BVerfGE derivan de las drogas son el peligro para la salud individual, el peligro de dependencia física y además la puesta en peligro de importantes intereses de la colectividad.

178 BVerfGE90,145(174).

179 Naciones Unidas ha reconocido, en especial en esta Convención, el merecimiento de pena de cualquier tráfico con estupefacientes porque la «salud y el bienestar de las personas se pone seriamente en peligro y las bases económicas, culturales y políticas de la sociedad se menoscaban».

180 BVerfGE 90, 145 (175). 
que la mejor forma de llevar a cabo ese control estatal es la de amenazar con pena todos los comportamientos relacionados con los productos derivados del cannabis.

Con el argumento ofrecido por el BVerfG para justificar la idoneidad de los delitos de peligro abstracto (prevención general), se plantea el problema, no exclusivo de los delitos de peligro abstracto, de la legitimidad de la prevención general para justificar el Derecho penal. En concreto, en relación con la prevención general negativa, las dudas de la doctrina se han centrado en la posibilidad de imposición de una pena a un sujeto que no es responsable del hecho, porque resulta necesario para evitar un mal social mayor. Pero también cabe plantearse hasta qué punto en las conminaciones penales abstractas la utilidad ha llevado al legislador a no respetar las exigencias derivadas de la proporcionalidad abstracta ${ }^{181}$. Tal y como plantea el Tribunal Constitucional español el juicio de idoneidad de una norma penal (SSTC 55/1996, 161/1997 y 136/1999), no habrá problema en afirmar la idoneidad de la prohibición contenida en el artículo $368 \mathrm{CP}$ para proteger el bien jurídico del que se trata, a través de la prevención general en el momento de la conminación penal, y de cualquier otro delito de peligro abstracto.

Como conclusión podemos afirmar, que serán idóneos los delitos de peligro abstracto para la protección de bienes jurídicos cuando, según la forma y la intensidad de los ataques, sea necesaria su protección frente a peligros abstractos; cuando se trate de prohibir comportamientos que no afectan de modo alguno al bien jurídico correspondiente serán inidóneos. Por otra parte, únicamente será idónea la prohibición penal de acciones peligrosas en abstracto cuando las distintas formas de actuación que se prohíben, normalmente supongan un peligro para el bien jurídico protegido y no cuando tan solamente en casos excepcionales puede suponer un peligro para el mismo ${ }^{182}$.

\section{V.2. B. Principio de necesidad y delitos de peligro abstracto}

\section{Principio de ofensividad y delitos de peligro abstracto}

Uno de los problemas a los que mayor atención ha prestado la doctrina, es el de la compatibilidad de los delitos de peligro abstracto con el principio de ofensividad. La razón no es otra que la imposibilidad, en un Ordenamiento jurídico presidido por el principio de ofensividad, de que la antijuricidad de un comportamiento se agote en la antijuricidad formal, sin que se exija la concurrencia de la antijuricidad material ${ }^{183}$.

181 SILVA SÁNCHEZ, Aproximación al Derecho..., cit., p. 215.

182 En el mismo sentido, GRASSHOF, BVerfGE 90, 145 (199 y ss.).

183 Tanto en el seno de la doctrina española como italiana, la crítica a los delitos de peligro abstracto ha girado en torno a la vigencia del principio de ofensividad y no al principio de culpabilidad, tal y como ha tenido lugar 
Las objeciones formuladas a esta categoría de delitos, atendiendo a la vigencia del principio de ofensividad, ha llevado a la doctrina a intentar dotar a estos delitos de antijuricidad material y conseguir la limitación de la punibilidad de los delitos de peligro abstracto. Con este fin, se han propuesto distintas soluciones reconducibles principalmente a dos: las opiniones orientadas a la producción de un resultado y aquellas que se orientan al comportamiento $^{184}$. Es posible dotar de un contenido material a los denominados delitos de peligro abstracto y, por lo tanto, considerarlos compatibles con uno de los subprincipios del principio de proporcionalidad en sentido amplio: el principio de exclusiva protección de bienes jurídicos y el correlativo principio de ofensividad. Desde nuestro punto de vista, para que los delitos de peligro abstracto resulten compatibles con el principio de exclusiva protección de bienes jurídicos y con el principio de ofensividad es necesario: por una parte, que a través de los mismos se intente proteger bienes jurídicos merecedores de pena, es decir, constitucionalmente legítimos y dotados de una especial relevancia social, puesto que implican una ampliación muy importante de la tutela penal; por otra parte, que a través de los delitos de peligro abstracto se tipifiquen aquellas conductas que aparezcan como generalmente peligrosas para el bien jurídico que se trata de proteger, y no aquellas conductas que sólo en algunos casos aparecen como peligrosas; en último lugar, que en el caso concreto el comportamiento sea efectivamente peligroso para el bien jurídico protegido ${ }^{185}$, en el sentido de que aparezca como peligroso ex ante para el bien jurídico, sin necesidad de que se produzca un peligro concreto, porque de lo contrario faltará el substrato de la antijuricidad material del mismo. Ahora bien, el hecho de que la categoría de los delitos de peligro abstracto, en cuanto tal, no sea necesariamente contraria al principio de exclusiva protección y al correlativo principio de ofensividad, no quiere decir que en todos los casos en los que el legislador ha recurrido a esta técnica de tipificación haya respetado estos principios. Siempre que el legislador haya tipificado injustos meramente formales o de mera desobediencia, se puede afirmar que ha conculcado no sólo el principio de idoneidad, como ya hemos tenido ocasión de comprobar ${ }^{186}$, sino también el principio de ofensividad y, por ende, el principio de proporcionalidad en sentido amplio.

principalmente en el seno de la doctrina alemana. Vid. AGUADO CORREA, El principio constitucional..., cit., p. 301, n.p.p. 119.

184 BERZ, Formelle Tatbestandverwirklichung und materialer Rechtsgüterschutz, München, 1986, p. 101.Estas opiniones doctrinales están desarrolladas en AGUADO CORREA, El principio constitucional..., cit., pp. 302 a 325.

185 RODRÍGUEZ MONTAÑÉS, Delitos de peligro..., cit., p. 298, habla de la necesidad de que los delitos de peligro abstracto representen un peligro real para el bien jurídico.

$186 \mathrm{Al}$ analizar el principio de idoneidad ya afirmábamos que la técnica de los delitos de peligro abstracto no es idónea para proteger a los bienes jurídicos cuando se trata de prohibir comportamientos que no afectan de modo alguno al bien jurídico. 


\section{Principio de subsidiariedad y delitos de peligro abstracto}

La técnica de los delitos de peligro abstracto aparece como idónea para proteger determinados bienes jurídicos ante acciones generalmente peligrosas, requiriendo la vigencia del principio de subsidiariedad que una determinada exigencia político-criminal justifique la introducción de la anticipación de la protección penal que supone la introducción de este tipo de delitos ${ }^{187}$.

En principio, tal y como ha puesto de manifiesto TIEDEMANN, la utilización de la técnica de los delitos de peligro abstracto no contraviene el principio constitucional de proporcionalidad y más concretamente el principio de subsidiariedad, ya que la prohibición de ejecutar ciertas acciones corresponde a la idea de que el Derecho penal sólo puede prohibir que se lleven a cabo comportamientos peligrosos y no a la idea de impedir que se produzca un resultado dañoso ${ }^{188}$. El problema se plantea cuando se trata de justificar, desde la perspectiva del principio de subsidiariedad, aquellos casos en los que se procede a utilizar la técnica de los delitos de peligro abstracto sin existir una exigencia de naturaleza político-criminal, sino debido a la dificultad de incriminar aquellos comportamientos que atentan contra bienes jurídicos cuyos contornos no están claramente definidos, sino todo lo contrario ${ }^{189}$. No olvidemos que ya la mera amenaza de una pena supone un grave menoscabo de los derechos de los afectados.

Tampoco serían justificables, desde el punto de vista del principio de subsidiariedad, aquellos casos en los que el legislador decide acudir a la técnica de los delitos de peligro abstracto para incriminar meros injustos administrativos, si bien en estos casos lo realmente criticable no es que haya acudido a la técnica de los delitos de peligro abstracto, sino que haya acudido al Derecho penal cuando han fallado el resto de la medidas, y más concretamente las medidas administrativas. En estos supuestos, aun cuando se pueda afirmar que nos encontramos ante un bien jurídico merecedor de tutela penal, no se puede afirmar que esté necesitado de tutela penal. Por todo ello consideramos contrarios al principio de subsidiariedad, y, por lo tanto, vulneradores del principio de proporcionalidad en sentido amplio, todos aquellos delitos de peligro abstracto que no son más que meras incriminaciones de injustos administrativos, aquellos «delitos de peligro abstracto absolutamente coincidentes con las infracciones administrativas que también existen en las leyes administrativas ${ }^{190}$.

187 Vid. en este sentido GÜNTHER, «Die Genese eines Straftatbestandes...», JuS, 1978, p. 12; GRASSO, «Die Vorvelegung des Strafrechtsschutzes...», en Beiheft zur ZStW, 1987, p. 92.

188 TIEDEMANN, Poder económico y delito (Introducción al Derecho penal económico y de la empresa), Barcelona, 1985, pp. 33 у 34.

189 Cfr. GRASSO, «Die Vorverlegung des Strafrechtsschutzes...», en Beiheft zur ZStW, 1987, p. 89.

190 MUÑOZ CONDE, «El "moderno" Derecho penal...», La Ley, 1996, p. 1339. 


\section{Control constitucional del respeto del principio de necesidad}

El legislador, a la hora de decidir sobre la necesidad de amenazar con pena un determinado comportamiento, posee una prerrogativa de evaluación y decisión que sólo en una medida muy restringida puede ser objeto de control por parte del Tribunal Constitucional. El legislador es plenamente libre para decidir qué bienes jurídicos son merecedores de protección, de manera que únicamente cuando los bienes jurídicos que haya decidido proteger penalmente se puedan tachar de constitucionalmente ilegítimos o socialmente irrelevantes, puede declarar el precepto correspondiente desproporcionado y, por ende, inconstitucional ${ }^{191}$. Por lo tanto, todos aquellos delitos de peligro abstracto que protejan bienes jurídicos constitucionalmente ilegítimos y, lo que puede ser más normal, socialmente irrelevantes, deberán ser declarados desproporcionados. No olvidemos que la mera amenaza de una pena, debido a la desaprobación moral que conlleva, supone un menoscabo grave de los derechos personales y de la libertad de actuación, debiendo tener lugar dicho ataque únicamente cuando estén en juego intereses o bienes comunitarios importantes, cuya protección constituye la función del Derecho penal. Además, y aun cuando el Tribunal Constitucional no haga referencia a este aspecto en sus pronunciamientos sobre el principio de proporcionalidad ${ }^{192}$, tan sólo el comportamiento que implique la lesión o puesta en peligro de los mismos será merecedor de pena y, por consiguiente, cuando el injusto se agote en la mera contradicción formal de un precepto no será ni merecedor ni estará necesitado de pena, por lo que habrá que declarar la desproporcionalidad y la inconstitucionalidad de aquellos preceptos que incriminen comportamientos que no impliquen la lesión o la puesta en peligro del bien jurídico protegido.

El control constitucional sobre la existencia o no de medidas alternativas menos gravosas pero de la misma eficacia tiene un alcance y una intensidad muy limitadas. Cuando el Tribunal Constitucional alemán se planteó la necesidad de acudir a la técnica de peligro abstracto para la protección del bien jurídico protegido a través de los preceptos de la BtMG, recordó la prerrogativa de evaluación y de decisión, la cual, no puede ser objeto de control por parte del alto Tribunal. En este sentido, afirmó que si el legislador, en el caso de la BtMG, decide que para la protección del bien jurídico es necesario y más idóneo la intimidación de un gran número de potenciales consumidores a través de la prohibición del comercio con el cannabis que la supresión de la amenaza penal, ello es conforme con

191 En la Sentencia del Tribunal Constitucional de 2 de octubre de 1997 se afirma: «Esta primera aproximación al problema de la proporcionalidad suscitado podría incluso conducir ya a su resolución desestimatoria "si el sacrificio de la libertad que impone la norma persigue la preservación de bienes o intereses, no sólo, por supuesto, constitucionalmente proscritos, sino ya también socialmente relevantes"».

192 También pone de manifiesto el hecho de que el BVerfG no haga referencia a este aspecto cuando analiza la exigencia de necesariedad, GRASSHOF en el voto particular a la BVerfGE 90, 145 (202). 
la Constitución ${ }^{193}$. El BVerfG afirma que puesto que la discusión político-criminal sobre la disminución del consumo de cannabis no está cerrada y se puede realizar tanto a través del efecto de prevención general del Derecho penal como a través de la liberalización del consumo de cannabis, no se puede objetar nada desde el punto de vista constitucional al recurso a la técnica del peligro abstracto.

Desde luego, este mismo argumento podría ofrecer el Tribunal Constitucional español en lo que respecta a la necesidad de una prohibición como la contenida en el artículo $368 \mathrm{CP}$ o en cualquier otro delito de peligro abstracto, puesto que ambos Tribunales comparten el criterio de que el legislador tiene un amplio ámbito de decisión y prerrogativa.

En conclusión, si bien la prohibición penal de determinadas actuaciones peligrosas en abstracto es necesaria solamente cuando éstas no puedan evitarse o no pueda reducirse su potencial de peligro mediante otros medios menos incisivos, contando el Estado con más posibilidades de reacción cuanto más se adelante la prohibición de determinadas acciones (en abstracto peligrosas) en relación con las acciones lesivas, difícilmente el Tribunal Constitucional se pronunciará sobre la desproporcionalidad de la misma. Y ello a pesar de que en muchos casos, debido a la injerencia que el Derecho penal implica, aparece como innecesario si no existen datos incontestables sobre la menor intensidad coactiva y una funcionalidad manifiestamente similar a la obtenida por la prohibición de los comportamientos generalmente peligrosos para el bien jurídico ${ }^{194}$. Por este motivo es por el que difícilmente se podrá declarar que un delito de peligro abstracto es contrario al principio de subsidiariedad y, por consiguiente, desproporcionado e inconstitucional.

\section{V.2.A. Principio de proporcionalidad en sentido estricto y delitos de peligro abstracto}

\section{Compatibilidad de los delitos de peligro abstracto con el principio de proporcionalidad en sentido estricto}

En el ámbito de los delitos de peligro abstracto, el principio de proporcionalidad en sentido estricto adquiere una especial relevancia al encontrarnos ante una prohibición de actuación, redactada de una forma amplia' ${ }^{195}$. En este análisis de la compatibilidad de los delitos de peligro abstracto con el principio de proporcionalidad en sentido estricto partiremos de lo afirmado por el Tribunal Constitucional alemán, debiendo aclarar que, aun cuando se

193 BVerfGE 90, 145 (183).

194 BVerfGE 90, 145 (182 y 183).

195 Sobre la importancia de este principio en relación con los delitos de peligro abstracto vid. el voto particular emitido por la juez GRASSHOF a la BVerfGE 90, 145 (203) 
refiere exclusivamente a algunos preceptos de la BtMG, desde nuestro punto de vista y tal como puso de manifiesto la juez GRASSHOF en el voto particular ${ }^{196}$ que formuló a esta sentencia, las consideraciones que lleva a cabo este Tribunal atinentes a la técnica del peligro abstracto, son extrapolables a todos aquellos preceptos penales en los que el legislador ha optado por esta técnica.

Cuando se trata de analizar la proporcionalidad en sentido estricto, el BVerfG señala que es preciso distinguir entre la prohibición de comercio con cannabis y, por otra parte, su refuerzo a través de la amenaza de una sanción penal, para las distintas formas de contravención del precepto - BVerfGE 90, 145 (183 y ss.)-. Por lo que respecta a la prohibición general de comercio con cannabis, señala que no cabe afirmar que sea contraria a la prohibición de exceso ya que se pretende hacer frente a los «peligros derivados de la droga para la salud de la sociedad y, en especial, para los jóvenes, así como proteger frente al peligro de dependencia psíquica de la droga y, por lo tanto, de la organizaciones criminales que dominan el mercado de la droga y de los efectos dañosos colectivos» [BVerfGE 90, 145 (184)]. Esta afirmación, según el Alto Tribunal alemán, también es válida cuando se trata de analizar la proporcionalidad de la amenaza con una sanción penal, puesto que no nos encontraríamos ante simples desobediencias de normas administrativas, es decir, ante injustos administrativos, sino que dichos comportamientos ponen en peligro intereses colectivos importantes, que son los que trata de proteger el legislador. Según el Tribunal Constitucional alemán, son motivos lo suficientemente justificados y claros los que llevan al legislador a considerar estas contravenciones como merecedoras y necesitadas de pena ${ }^{197}$. Tampoco habría nada que objetar al hecho de que el legislador haya decidido prescindir de la técnica de la lesión y del peligro concreto y se haya decantado por acudir a la técnica del peligro abstracto: los tipos penales sobre el comercio de productos derivados del cannabis pretenden llevar a cabo la protección de los correspondientes bienes jurídicos, abarcando todos los comportamientos que son generalmente idóneos para crear el peligro descrito, lo cual se justifica por motivos de prevención general ${ }^{198}$. Sin embargo, el Tribunal Constitucional reconoce que la propia naturaleza de una protección penal entendida de esta manera, implica que los tipos penales comprendan comportamientos que presentan una notable diferencia en relación con la clase y la intensidad del peligro que representa para el bien jurídico, y en relación con el contenido de injusto y de culpabilidad individual. El peligro para los bienes jurídicos comunitarios puede alcanzar una intensidad tan insignificante, si se atiende a las propiedades y clase de droga, la cantidad encontrada en el caso concreto, la clase de contravención 
ante la que nos encontramos, así como todas aquellas circunstancias relevantes en relación con el peligro, que los motivos de prevención general que son los que justifican la amenaza con una sanción penal, perderían peso.

Por todo ello resulta fundamental, desde nuestro punto de vista, la afirmación del BVerfG en la que señala que la pena podría aparecer como excesiva y, por ende, inconstitucional, si se atiende a los derechos del afectado, a la culpabilidad individual del autor y a los fines político-criminales de prevención especial que de ella se desprenden ${ }^{199}$. Como sabemos, la protección de los bienes jurídicos a través de la amenaza de una sanción penal se lleva a cabo mediante el mecanismo de la prevención general y de la prevención especial. Pero puede suceder que en los supuestos en los que la puesta en peligro de los bienes jurídicos sea insignificante, la prevención general, que es la que en los delitos de peligro abstracto juega un papel fundamental en la justificación de los mismos, ceda ante las necesidades de prevención especial, y atendiendo tanto a la culpabilidad insignificante y los predominantes fines de prevención especial, la pena puede ser desproporcionada ${ }^{200}$. Solamente en aquellos casos en los que nos encontremos ante comportamientos de una cierta peligrosidad para el bien jurídico protegido no deberán ceder las necesidades de prevención general frente a la especial ${ }^{201}$. Como vimos al exponer el principio de proporcionalidad en sentido estricto, en la conminación penal abstracta el legislador debe partir de criterios de proporcionalidad entre el injusto y la pena, pero también debe incorporar, aparte de criterios de prevención general, criterios de prevención especial. Por ello, el legislador debe prever una solución para aquellos casos en los que la pena imponible al autor aparezca como desproporcionada si se atiende tanto a la insignificancia del injusto como del grado de culpabilidad y a las exigencias de prevención especial.

No porque el legislador considere idóneo y necesario para alcanzar la pretendida protección de bienes jurídicos amenazar con una sanción penal el comercio prohibido con productos derivados del cannabis, sobra el examen de la proporcionalidad en sentido estricto. Muy al contrario, el tercer nivel del principio de proporcionalidad en sentido amplio pretende ser un control de signo opuesto de aquellas medidas que han sido consideradas idóneas y necesarias, en el sentido de si los medios utilizados, que son los que causan esa restricción de derechos fundamentales en los afectados, se encuentran en una relación de proporción con la protección del bien jurídico que a través de los mismos se pretende alcanzar. Este examen puede llevar a la conclusión de que un medio en principio idóneo y necesario para la protección del bien jurídico, no debe ser utilizado porque el menoscabo 
de derechos fundamentales del afectado que conlleva supera el aumento de protección del bien jurídico, de manera que la utilización de dicho medio de protección, puede ser reputado desproporcionado. Ello implica que bajo determinadas circunstancias se deja de proteger legítimamente el bien jurídico porque, de lo contrario, se produciría un menoscabo desproporcionado de los derechos fundamentales ${ }^{202}$.

Y esto puede ocurrir, desde nuestro punto de vista, no sólo en materia de drogas, sino en todos aquellos casos en los que el bien jurídico es amenazado de forma tan variada, que las puestas en peligro que padece son de muy diversa intensidad, resultando una tarea muy difícil, si no imposible para el legislador, prever distintas medidas de protección atendiendo al diverso grado de peligrosidad de una determinada acción. De manera que puede haber casos en los que el legislador considera que la técnica más adecuada y necesaria para la protección de bienes jurídicos es la de prohibir comportamientos generalmente peligrosos para el bien jurídico en cuestión, considerando el comportamiento de peligro abstracto en cuanto tal como merecedor y necesitado de pena, sin que en principio exista posibilidad de «privilegiar punitivamente» aquellas formas de actuación que revisten una peligrosidad escasa. Como recordaremos, en virtud de la vigencia del principio de fragmentariedad, el límite inferior del principio de proporcionalidad en sentido amplio será traspasado por aquellos comportamientos amenazados con pena que no aparezcan como tales, suficientemente peligrosos para el bien jurídico protegido, pero no por aquellos otros que son considerados como generalmente peligrosos, aun cuando en el caso concreto nos encontremos ante un comportamiento escasamente peligroso. En tanto que los elementos o requisitos del principio de proporcionalidad en sentido amplio de idoneidad y necesidad justifiquen la incriminación de comportamientos generalmente peligrosos y los trate de una manera indiferenciada como merecedores y necesitados de pena, el tercer elemento o requisito del principio de proporcionalidad en sentido amplio, el principio de proporcionalidad en sentido estricto, adquiere aún mayor relevancia.

Cuanto más amplia es la tipificación que lleva a cabo el legislador penal de las conductas peligrosas en abstracto para el bien jurídico, más en serio ha de tomarse la posibilidad de que queden comprendidos por el tipo comportamientos que sólo resultan peligrosos para el bien jurídico de una manera insignificante. Y es para tales situaciones en las que el contenido de injusto es irrelevante, para las que el legislador ha de prever soluciones que permitan evitar un excesivo gravamen, un excesivo perjuicio al afectado por la persecución y, en su caso, evitar la imposición de la pena prevista en el correspondiente precepto, al cual en principio no cabe hacer reparo alguno. Pero no olvidemos que el principio de proporcio- 
nalidad en sentido estricto coincide en su efecto limitador de la pena con el principio de culpabilidad, de manera que la pena imponible a una determinada persona ha de guardar una relación de proporcionalidad tanto con el grado de injusto como con el grado de culpabilidad individual, por lo que el legislador habrá de incluir una regulación que permita a los órganos de persecución y al Juez, adoptar en los casos concretos aquellas reacciones que se encuentren en una relación de proporcionalidad tanto con el correspondiente grado de peligrosidad como el grado de culpabilidad, de forma que no grave al afectado de una manera inexigible $e^{203}$.

El propio Tribunal Constitucional alemán nos apunta las posibilidades que posee el legislador para respetar el principio de proporcionalidad en sentido estricto en los supuestos de injusto y culpabilidad insignificante: una solución jurídico-material y una solución formal. En virtud de la primera de ellas, el legislador puede, a través de tipos privilegiados, reducir el ámbito de aplicación de los preceptos penales o bien posibilitar la imposición de sanciones especiales para los casos de criminalidad de bagatela. La solución procesal, que es la que ha adoptado el legislador alemán en la Ley Procesal Penal, consiste en reducir o relajar las necesidades de persecución penal ${ }^{204}$. En conclusión, el principio de proporcionalidad en sentido estricto y el principio de culpabilidad, exigen que siempre que el legislador considere idóneo y necesario para la protección de un bien jurídico amenazar con pena de una forma indiscriminada todos aquellos comportamientos generalmente peligrosos para el mismo, sin privilegiar los escasamente peligrosos, habrá de incluir las previsiones necesarias que permitan encontrar la pena que se encuentre en una relación proporcional tanto con el grado de injusto como con el de culpabilidad individual del autor. Y así ha procedido finalmente el legislador español en relación con el tipo básico de tráfico de drogas previsto en el art. $368 \mathrm{CP}$ tras la reforma sufrida por éste a través de la LO 5/2010. A través de ésta reforma además de reducir el límite máximo a imponer por delito de tráfico de drogas de los que causan grave daño a la salud (de 9 a 6 años), se ha previsto la facultad de reducir la pena de prisión para los supuestos de escasa entidad, facilitándose de este modo que puedan aplicar alternativas a la pena de prisión, como la suspensión o la sustitución. El párrafo $2 .^{\circ}$ del art. $368 \mathrm{CP}$ reza así: "No

203 Cfr. GRASSHOF, BVerfGE 90, 145 (203); BVerfGE 50, 205 (213 y ss.); 54, 100 (109 y ss.). Sobre la armonización de los delitos de peligro abstractoy el principio de proprocionalidad en sentido estricto vid. vid. AGUADO CORREA, El principio constitucional..., cit., pp. 337 a 390, donde se analizan las soluciones que se podrían prever en la ley en orden a esta armonización, centrándonos en las soluciones formal y material a las que se refiere el BVerfG.

204 BVerfGE 90, 145 (191). Esta opción, tal y como aclara el alto Tribunal alemán, no puede ser tachada de inconstitucional al no contravenir ningún principio constitucional, concretamente, el principio de legalidad penal contemplado en el artículo 103.2 GG, de manera que la prohibición de retroactividad de leyes penales más graves, la necesidad de previsión legal de la punibilidad, así como la determinación de la ley, no se ven afectadas por la misma. 
obstante lo dispuesto en el párrafo anterior, los tribunales podrán imponer la pena inferior en grado a las señaladas en atención a la escasa entidad del hecho y a las circunstancias personales del culpable. No se podrá hacer uso de esta facultad si concurriere alguna de las circunstancias a que se hace referencia en los artículos 369 bis y 370". A través de esta previsión, el legislador ha refrendado la práctica judicial plasmada en el Acuerdo del Pleno

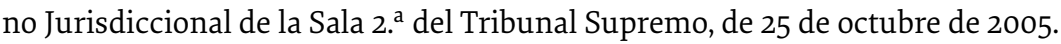

\section{Control constitucional del respeto del principio de proporcionalidad en sentido estricto}

El control que puede llevar a cabo el Tribunal Constitucional en aquellos casos en los que el legislador no ha tenido en cuenta las exigencias del principio de proporcionalidad es más intenso que el control que puede realizar en relación con el principio de idoneidad y de necesidad. Por este motivo, el Alto Tribunal podrá declarar inconstitucional todos aquellos preceptos en los que, habiéndose acudido a la técnica de los delitos de peligro abstracto, el legislador no ha tenido presente «la razonable exigibilidad de una conducta y la proporcionalidad en caso de incumplimiento... (STC 53/1989, FJ 9)». Siempre que la imposición de la pena suponga un sacrificio innecesario y excesivo del derecho a la libertad reconocido en el artículo $17 \mathrm{CE}$, se podrá apreciar la vulneración del principio de proporcionalidad en sentido estricto. Por lo tanto, se podrán declarar contrarios a este principio todos aquellos preceptos en los cuales no se contemplan las previsiones necesarias para adecuar la pena al contenido de injusto y de culpabilidad individual. Prueba de ello es que, en la Sentencia 136/1999, de 26 de abril, el Tribunal Constitucional español declaró, por primera y única vez, la inconstitucionalidad de un precepto penal que contenía un delito de peligro abstracto, por infringir el principio de proporcionalidad en sentido estricto, en concreto, la proporcionalidad abstracta, fallando: «El precepto resulta, en efecto, inconstitucional únicamente en la medida en que no incorpora previsión alguna que hubiera permitido atemperar la sanción penal a la entidad de actos de colaboración con banda armada que, si bien pueden en ocasiones ser de escasa trascendencia en atención al bien jurídico protegido, no por ello deben quedar impunes. Expresado en otros términos, no es la apertura de la conducta típica de colaboración con banda armada la que resulta constitucionalmente objetable, sino la ausencia en el precepto de la correspondiente previsión que hubiera permitido al juzgador, en casos como el presente, imponer una pena inferior a la de prisión mayor en su grado mínimo» (FJ 30). 


\title{
Risco, «inimigo» e o direito penal do futuro ${ }^{1}$
}

\author{
HERMÍNIO CARLOS SILVA RODRIGUES
}

hcsrod@gmail.com

GALILEU - REVISTA DE DIREITO E ECONOMIA - e-ISSN 2184-1845

Volume XX $\cdot 1^{\text {st }}$ July Julho $-31^{\text {TH }}$ December Dezembro $2019 \cdot$ pp. 151-195

DOI: http://doi.org/10.26619/2184-1845.XX.2.7

Submitted on October $22^{\text {th }}, 2019 \cdot$ Accepted on November $15^{\text {th }}, 2019$

Submetido em 22 de Outubro, 2019 . Aceite a 15 de Novembro, 2019

RESUMO No contexto da sociedade pós-industrial e pós-moderna em que vivemos, colocam-se novos desafios ao direito penal. O emergir de novos e grandes riscos capazes de ameaçar a estabilidade e a paz das sociedades ao nível global, a criminalidade global e altamente organizada que, em densas e complexas redes se introduz em todos os sectores da sociedade, bem como o sentimento de falência dos sistemas e das instituições para o controlo eficaz das consequências de tais fenómenos, criaram nas pessoas a sensação de insegurança e descrença nesta era do «pós».

Resultado deste sentimento global de insegurança que as transformações sociais do princípio do milénio e o emergir do terrorismo como nova ameaça global trouxeram, ocorre o movimento de «fuga para o direito penal». Os estados recorrem cada vez mais ao direito penal no sentido de controlar o risco e criar percepção de segurança nas populações, ultrapassando, muitas das vezes, os próprios limites da sua função de protecção exclusiva de bens jurídicos. O direito penal aparece cada vez mais funcionalizado a programas de política criminal securitária, cujo escopo principal é o de garantir a segurança e a paz social, recorrendo a soluções de antecipação da tutela penal, tendo com finalidade primária a integridade do sistema. Estas estratégias político-criminais estimularam doutrinas que propõem uma total funcionalização do direito penal às finalidades de prevenção geral integradora, elegendo como principal alvo da sua intervenção securitária todo aquele que seja conotado com grupos de risco, os suspeitos de ligações à criminalidade altamente organizada e transnacional e, principalmente, os suspeitos de actividades terroristas. Este sujeito é tratado como «inimigo» do sistema, elemento perturbador cuja perigosidade é necessário inocuizar, não só através do

1 O presente trabalho corresponde ao relatório da unidade curricular «O Direito - Da norma ao procedimento e à fase aplicativa» do Curso de Doutoramento em Direito do Departamento de Direito da Universidade Autónoma de Lisboa, sob a orientação do Prof. Doutor Manuel Monteiro Guedes Valente. Nota: o autor escreve segundo a grafia anterior à norma do acordo ortográfico. 
reforço exponencial da tutela repressiva, mas também da implementação de uma intolerável antecipação da tutela penal através de medidas de prevenção avançada.

A esta tendência deve contrapor-se um direito penal inspirado na dignidade da pessoa humana, que seja capaz de proteger os bens jurídicos fundamentais da comunidade sem sacrificar as garantias constitucionais da pessoa, património imaterial herdado do racionalismo humanista: é preciso (re)construir um direito penal de liberdade.

PALAVRAS-CHAVE Pós-modernidade; risco; inimigo; segurança; liberdade; justiça

ABSTRACT In the context of the postindustrial and postmodern society in which we live, new challenges to criminal law arise. The emergence of new and great risks that threaten the stability and peace of societies at the global level, the global and highly organized crime which, in dense and complex networks, is introduced in all sectors of society, as well as the feeling that systems and institutions are failing to effectively control the consequences of such phenomena have created a sense of insecurity and disbelief in this post-post age. As a result of this global sense of insecurity that the social transformations of the early years of this millennium and the emergence of terrorism as a new global threat have brought about, there is a actual movement towards criminal law. States are increasingly resorting to criminal law to control risk and create perceptions of security among populations, often exceeding the limits of their role of exclusive protection of fundamental rights.

Criminal law appears increasingly functionalized to security policy programs, whose main scope is to ensure social tranquility and peace, using solutions to anticipate criminal protection, with the primary purpose of the integrity of the system. These strategies have stimulated doctrines that propose a full functionalization of criminal law for the purposes of integrative general prevention, choosing as the main target of their security intervention those who are connoted with risk groups, the suspects of links to highly organized and transnational crime, and especially those suspected of terrorist activities. This subject is treated as an «enemy» of the system, a disturbing element that must be controlled not only through the exponential reinforcement of repressive protection, but also through the implementation of an intolerable anticipation of criminal protection through advanced prevention measures.

This tendency must be countered by a criminal law based on the dignity of the human being, which is capable of protecting the fundamental legal assets of the community without sacrificing the constitutional guarantees, which are an intangible heritage inherited from humanist rationalism. It's mandatory that we rebuild a criminal law on the foundations of liberty itself.

KEY-WORDS Post-modernity; risk; enemy; security; liberty; justice. 


\section{Globalização, pós-modernidade e risco}

Tem sido frequente, na esteira de BECK, qualificar a sociedade pós-industrial ${ }^{2}$ como uma «sociedade de risco». ${ }^{3}$ Este novo paradigma societário emergente da pós-modernidade é marcado pela globalização, pela integração supranacional ${ }^{4}$, pela imprevisibilidade dos acontecimentos, pelo predomínio do económico sobre o político ${ }^{5}$, pelo incremento da criminalidade organizada ${ }^{6}$ e transnacional 7 , pelo descrédito nas instâncias de protecção e por uma maior relevância do crime macrossocial ${ }^{8}$, o que faz surgir sentimentos de insegurança. $\mathrm{O}$ desenvolvimento desmedido, norteado pela busca incessante do progresso e orientado por uma «racionalidade calculadora e instrumental», conduziu à crescente tecnificação, cientificação, economização, burocratização e juridificação do mundo e faz surgir uma nova espécie de riscos: os chamados «grandes e novos riscos»", aqueles que ameaçam as sociedades pós-industriais e cuja verificação não pode ser antecipada pela razão calculadora de riscos, nem travada nos seus «macro-efeitos» pelas técnicas actuais. Surge a percepção de que, afinal, a tecnociência pode conduzir a uma destruição incontrolável..$^{10}$ É a descrença das sociedades actuais na racionalidade instrumental em falência ${ }^{11}$, o que provoca o temor generalizado em torno dos eventos imprevisíveis.

O novo paradigma ${ }^{12}$ talhado por $\mathrm{BECK}^{13}$, chama a atenção, precisamente, para o lado mais pernicioso do desenfreado desenvolvimento da técnica (aquilo a que expressivamente

2 Cfr. Domenico de MASI, A Sociedade Pós-Industrial, 3. ${ }^{\text {a }}$ ed., Senac, São Paulo, 200o, pp. 11 e ss.

3 Cfr. Ulrich BECK, La Sociedade del Riesgo. Hacia una Nueva Modernidad, Paidós, 1998, passim, apud Hermínio RODRIGUES, Responsabilidade Penal de Pessoas Colectivas: Uma Revisitação à Luz da Teoria do Risco. Lisboa: Universidade Autónoma de Lisboa, 2016, 122 p. Dissertação de Mestrado (polic.). Vide, tb., Ulrich BECK. La Sociedad Del Riesgo Mundial: En busca de la seguridad perdida, Paidós, Barcelona, 2008; Ulrich BECK. La Sociedad Del Riesgo Global, Siglo XXI de España Madrid, 2002.

4 Cfr. Francisco LUCAS PIRES, Introdução ao Direito Constitucional Europeu, Almedina, Coimbra, 1997, pp. 11 e ss. Vide, ainda, Augusto SILVA DIAS, Protecção Jurídico-Penal dos Interesses dos Consumidores, 3 . $^{\text {a }}$ ed. polic, FDUC - IDPEE, Coimbra, 2001.

5 José Manuel PUREZA, O Património Comum da Humanidade - Rumo a um Direito Internacional da Solidariedade, Afrontamento, Lisboa, 1998, p. 17.

6 Cfr. A. SILVA FRANCO, Globalização e Criminalidade dos Poderosos, RPCC, Ano 10 - Fasc. 2..$^{\circ}$, Abril - Junho de 2000 , pp. 217 e ss.

7 Cfr. FARIA COSTA, O Fenómeno da Globalização e o Direito Penal Económico, BFDUC, Stvdia Ivridica, n. ${ }^{\circ}$ 61, Outubro de 2001, Coimbra, Coimbra Editora, 2001, pp. 540 e ss.

8 Cfr. Mário FERREIRA MONTE, O Futuro tem Direito Penal? O Direito Penal tem futuro? Apontamento introdutório à obra de Paulo S. FERNANDES, Globalização, "Sociedade de Risco" e o Futuro do Direito Penal, Almedina, Coimbra, 2001.

9 Ulrich BECK, ibidem. Cfr. Hermínio RODRIGUES, op. cit., p. 16.

10 Cfr. Federico STELLA, Giustizia e Modernitá. La Protezione dell' Inoccente e la Tutela delle Vittime, Giuffre Editore, Milano, 2002, prefácio, p. 7. Cfr. Hermínio RODRIGUES, op. cit., p. 17.

11 Cfr. Alain TOURAINE, Crítica da Modernidade, Piaget, Lisboa, 1994, p. 220.

12 Cfr. Rodrigo CARDOZO POZO (Bases de La Politica Criminal e Protección Penal de la Seguridad Vial, Universidad de Salamanca, 2009, 509 f., Tese de Doutoramento, p. 106): "Esa sociedad del riesgo, cuya denominación a partir de la obra de BECK alcanzó el carácter de «paradigma» y, por lo mismo, una nueva plataforma para ver y comprender la sociedad.". Cfr. Hermínio RODRIGUES, op. cit., p. 17.

13 Ulrich BECK, Op. cit., p. 46. Cfr. Hermínio RODRIGUES, op. cit., p. 17. 
chama "o lado obscuro do progresso"), com a consequente falácia do seu sistema de cálculo de riscos, o que implica consequências negativas susceptíveis de fazer perigar a continuidade da própria sociedade, enquanto estrutura organizatória da convivência entre os humanos. As sociedades modernas confrontam-se com os fundamentos e limites do seu próprio modelo e, ao mesmo tempo que conservam as suas estruturas, não reflectem sobre os seus efeitos. É a dimensão esmagadora dos efeitos secundários de longo prazo que faz com que a sociedade pós-industrial tome consciência dos grandes riscos promovidos pela sua racionalidade fundante e se transforme em uma «sociedade do risco», num processo a que BECK chama de "modernização reflexiva"

A "sociedade do risco" é uma sociedade catastrófica, o que requer uma constante reorganização do poder e da responsabilidade, pois que os estados de excepção tendem a converter-se em estados de normalidade. A sociedade da informação potencia uma percepção generalizada de insegurança ao amplificar fenómenos como o terrorismo internacional e os acidentes tecnológicos, o que os torna especialmente vívidos na mente do cidadão, o qual, deste modo, interioriza a noção de risco permanente, experimentando a incerteza, a antecipação dos acontecimentos. O cidadão vive o real ainda não acontecido, pela noção que tem da iminência dos fenómenos. ${ }^{15}$

Esta «sociedade do risco» traz um dado novo: a diferenciação entre risco e perigo, noções não inteiramente coincidentes. A potenciação dos novos riscos decorre sempre de decisões humanas ${ }^{16}$, podendo perspectivar-se como auto-agressões da sociedade sobre si mesma. Já os perigos, enquanto dramas humanos, não resultam de decisões baseadas em critérios de oportunidade técnico-económica. Conforme aponta LUHMANN $^{17}$, vivemos actualmente em um contexto societário no qual se perspectiva o futuro com base numa lógica do «risco das decisões». E este problema pode tornar-se exponencial à medida que mais decisões são tomadas em cadeia, como consequência umas das outras. O risco torna-se não só global, como transgeracional. ${ }^{18}$

A globalização trouxe progressos à humanidade. No entanto, tal aproximação de povos e culturas num grande espaço de contacto e miscigenação a todos os níveis, trouxe, também, riscos desconhecidos e, consequentemente, as sociedades tendem para a incerteza, a

14 Ulrich BECK, D’Une Théorie Critique de la Société, p. 338 e ss., apud SILVA DIAS, Op. cit., p. 4. Cfr. Hermínio RODRIGUES, op. cit., p. 18.

15 Cfr. Ulrich BECK, La Sociedad del Riesgo..., cit. pp. 39 e ss.

16 Cfr. Susana AIRES DE SOUSA, Risco, precaução e responsabilidade no horizonte da incerteza, in: Estudos em Homenagem ao Professor Doutor José Joaquim Gomes Canotilho, BFD, Stvdia Juridica n. ${ }^{\circ}$ 102, Coimbra Editora, Coimbra, 2012 , p. 685. Cfr. Hermínio RODRIGUES, op. cit., p. 19.

17 Niklas LUHMANN, Risk: A Sociological Theory, Walter De Gruyter, Berlin-New York, 1993, p. 23. Cfr. Hermínio RODRIGUES, op. cit.. p. 19.

18 Cfr. François OST, O Tempo do Direito, Piaget, Lisboa, 2001, p. 345. 
insegurança e a instabilidade. GIDDENS considera que a globalização gerou uma sociedade global marcada pela "intersecção da presença e da ausência"19 e caracterizada pelo "entrelaçamento de eventos sociais e relações sociais que estão à distância de contextos locais"20. $\mathrm{O}$ efeito «globalização» acarreta, então, outro elemento decisivo para a incontrolabilidade dos novos riscos: a sua ubiquidade e a dos seus factores potenciadores. ${ }^{21} \mathrm{Hoje}$, ao contrário dos primeiros tempos do progresso da tecnociência nas sociedades pré-industrial e industrial, os riscos não são delimitáveis a um espaço e a um tempo, "os seus efeitos expandem-se por extensões consideráveis do planeta, arrastam-se por períodos mais ou menos longos e impossibilitam a determinação do círculo dos afectados" ${ }^{22}$. A este respeito, refere-se BECK ${ }^{23}$ ao fenómeno que designa por «efeito boomerang», processo através do qual agentes do crime e vítimas do mesmo se confundem pela indeterminação do espaço em que os efeitos nocivos se fazem sentir e pela absoluta imprevisibilidade do número de pessoas que poderão afectar. ${ }^{24}$ Diz-nos FIGUEIREDO DIAS ${ }^{25}$ que este fenómeno é próprio da transição da sociedade industrial para uma sociedade tecnológica global, onde a massificação das acções humanas é capaz de produzir riscos globais. Este quadro coloca em crise o paradigma do direito penal liberal, pensado para a sociedade industrial no contexto da qual os riscos para os bens jurídicos essenciais à vida em comunidade provinham de acções humanas individuais, com actores bem definidos, para a contenção dos quais eram suficientes os bens jurídicos individuais e a dogmática tradicional, pensada para as formas individuais do agir e para uma criminalidade de contexto local.

A sociedade de hoje convive com uma criminalidade estrutural, estruturada e global. A globalização económica, política, tecnológica e cultural ${ }^{26}$ alargou os horizontes da crimina$\operatorname{lidade}^{27}$, a qual, aproveitando ao máximo os novos espaços de actuação, as novas tecnologias

19 Anthony GIDDENS, As Consequências da Modernidade, Celta, Lisboa, 1992, p. 27. Cfr. Hermínio RODRIGUES, op. cit., p. 17.

20 Idem, ibidem.

21 Cfr. Daniel INNERARITY, A Sociedade Invisivel, Teorema, Lisboa, 2009, p. 9; Hermínio RODRIGUES, op. cit.

22 Augusto SILVA DIAS, Op. cit., p. 4. Cfr. Hermínio RODRIGUES, op. cit., p. 20.

23 Ulrich BECK, apud Augusto SILVA DIAS, ibidem. Cfr. Hermínio RODRIGUES, ibidem.

24 Realidade esta que contrasta com aqueloutra descrita por DUPUY (apud José Manuel PUREZA, Op. cit., p. 25): "Vasto mundo, rico em países longínquos, vivendo na feliz ignorância uns do outros". Cfr. Hermínio RODRIGUES, op. cit., p. 20.

25 Jorge de FIGUEIREDO DIAS, Direito Penal, Parte Geral - Tomo I, Coimbra Editora, Coimbra, 2004, pp. 127 e ss. Vide, tb. Jorge de FIGUEIREDO DIAS, O Direito Penal entre a "Sociedade industrial" e a "Sociedade do Risco", in: Estudos em Homenagem ao Prof. Doutor Rogério Soares, BFDUC, Stvdia Ivridica, n. ${ }^{\circ} 61$, Outubro de 2001, p. 583 e ss.

26 Cfr. Anthony GIDDENS, O Mundo na Era da Globalização, Editorial Presença, 200o, p. 22 e ss.

27 Sobre a relação entre globalização e criminalidade global, vide DIAS DUARTE, Branqueamento de Capitais. O Regime do D.L. 15/93 de 22 de Janeiro e a Normativa Internacional, Porto, Universidade Católica, 2002, p. 17. Céptico (estamos em crer) acerca desta relação está PRITTWITZ. Cfr. Cornelius PRITTWITZ. Sociedad del Riesgo y Derecho Penal, in: ARROYO ZAPATERO / NEUMANN / NIETO MARTÍN, Crítica y justificación del Derecho penal en el cambio de siglo. El análisis crítico de la Escuela de Frankfurt, Universidad de Castilla-La Mancha, Cuenca, 2003, p. 149. 
e as novas dinâmicas de organização social ${ }^{28}$ resultantes do recuo da influência dos Estados no tecido social internacionalizou-se, integrou-se socialmente ${ }^{29}$ e organizou-se, assumindo características alheias à ideia de delinquência como fenómeno marginal. Afirma, a propósito, Anabela MIRANDA RODRIGUES: "a nova criminalidade é expressão deste novo modelo de organização social para que tendem as sociedades contemporâneas" ${ }^{30}$, ou seja, um modelo de sociedade polarizada em múltiplas redes, que a tornam multiforme e policêntrica.

A criminalidade deixou de estar à margem da sociedade para fazer parte dela, de modo que, hoje pode dizer-se que existe uma simbiose entre sociedade e crime, já que a criminalidade está infiltrada nos centros de decisão políticos, económicos e financeiros e processa-se em complexas redes criminosas, as quais aproveitam as estruturas e instituições sociais, confundindo-se com elas ${ }^{31}$. Há como que uma porosidade entre a sociedade oficial e a sociedade do crime $^{32}$, aumentando exponencialmente a dificuldade da detecção e, inclusive, a percepção da actividade criminosa. ${ }^{33}$

Por outro lado, o recuo do Estado Social ${ }^{34}$ expôs as sociedades a mecanismos de autorregulação dos mercados e à desinstitucionalização dos procedimentos. Isto gera incerteza e receio como reacção aos novos fenómenos globais como o terrorismo e a criminalidade grave e altamente organizada, aquilo que Hans JONAS chamou de «heurística do medo»35 Este novo paradigma sociológico possibilita o surgimento de totalitarismos, novos leviatãs que, através de discursos populistas, pretendem instituir regimes jurídicos funcionalizados a gerar percepção de segurança nas populações ${ }^{36}$, fazendo variar as suas políticas de segurança entre "os extremos da «segurança da normalidade» e a «segurança da excepção».37

28 Cfr. Anabela MIRANDA RODRIGUES, Criminalidade Organizada - Que Política Criminal?, in: Direito Penal Económico e Europeu - Textos Doutrinários, III vol., IDPEE, Coimbra Editora, Coimbra, 2009, p. 187.

29 Jean DE MAILLARD, Crimes e Leis, Piaget, Lisboa, 1995, pp. 94.

30 Anabela MIRANDA RODRIGUES, ibidem. Cfr. Hermínio RODRIGUES, op. cit., p. 60.

31 É, no fundo, a «sociedade fractal» de que nos fala Jean de MAILLARD. Cfr. Jean de MAILLARD, L' Avenir du Crime, Flammarion, 1997, pp. 43 e ss., apud, Anabela Miranda RODRIGUES, Criminalidade Organizada..., cit., 185.

32 Cfr. Jean DE MAILLARD, Crimes e Leis, cit., p. 91.

33 Cfr. Anabela MIRANDA RODRIGUES, Política Criminal - Novos Desafios, Velhos Rumos, in: Liber Discipulorum para Figueiredo Dias, Coimbra Editora, Coimbra, 2003, p. 207; Vitalino CANAS (O Crime de Branqueamento de Capitais - Regime de Prevenção e Repressão, Almedina, Coimbra, 2004, p. 10; Hans SCHNEIDER, Recientes investigaciones criminológicas sobre la criminalidad organizada", in: Revista de Derecho Penal y Criminologia, 3, 1993, p. 723.

34 Cfr. François OST, O Tempo do Direito, Piaget, Lisboa, 2001, p. 337. Sobre os efeitos da globalização sobre a própria noção de Estado na pós-modernidade, cfr. J. Peter ANDERSON, Política Global do Poder, Justiça e Morte, Piaget, Lisboa, 1998, pp. 103 e ss.

35 Cfr. Idem, ibidem. Quanto à teoria de JONAS, vide Hans JONAS, El principio de responsabilidad: ensayo de una ética para la civilización tecnológica, Herder, Barcelona, 1995, p. 29 e ss.

36 Cfr. François OST, O Tempo do Direito, Piaget, Lisboa, 2001, pp. 342-343.

37 Jorge BACELAR GOUVEIA, Direito da Segurança, Almedina, Coimbra, 2018, p. 54. 
Assim, em contraste com o fraco intervencionismo social do direito penal liberal do iluminismo, a pós-modernidade é marcada por uma tendência de sobrepenalização, no contexto de um incremento do recurso ao Direito em geral, como fenómeno de regulação, no sentido de restituir uma certa orientação às sociedades carentes de referentes. É o ordo-liberalismo posto em prática. No entanto, esta juridificação cada vez maior de todo o quotidiano, torna o próprio Direito numa ameaça mais presente do que a própria protecção que confere, o que é fortemente acentuado pela crescente instabilidade legislativa fruto de uma certa precarização do Direito e dos seus princípios. As sociedades pós-modernas reagem à ameaça dos grandes e novos riscos com nervosismo e intranquilidade, o que tem causado um alargamento da responsabilidade jurídica em geral e penal em particular. No que tange à responsabilidade penal, a percepção do risco social instala uma crise sistémica: se, por um lado, se afirma que a protecção e recuperação do tecido social é, ainda, tarefa do direito penal, por outro afirma-se a inépcia dos seus princípios liberais.

É, assim, que, na resposta penal aos novos desafios da sociedade pós-moderna, vão pontuar duas grandes tendências: a expansão do direito penal, marcada pela sua desformalização e funcionalização exacerbada, elegendo como bem jurídico supremo a segurança cognitiva e atingindo o seu auge no "direito penal do inimigo"; por outro lado, a reafirmação de um direito penal mínimo, orientado para a protecção exclusiva, subsidiária e fragmentária de bens jurídicos, favorecendo a culpa como critério de imputação subjectiva e a liberdade como critério processual reitor.

A intervenção jurídico-penal do Estado Moderno passa, então, por duas fases: a invenção do Estado pela necessidade do estabelecimento da paz pública; a afirmação dos direitos e das liberdades dos indivíduos em face do Estado omnipotente; No Estado Pós-Moderno surge o valor da segurança colectiva como contraponto do exercício das liberdades individuais. Nesta sede, o grande problema da actualidade está em estabelecer a simbiose vital entre liberdade e segurança, para que os termos do binómio não se anulem mutuamente.

Iluminismo absolutista, garantismo humanista e funcionalismo securitário: da repressão à liberdade; do direito penal mínimo à ilusão de segurança e à crise do humanismo penal

\section{As origens remotas do «direito penal do inimigo»}

A ideia de que a justiça não é necessariamente igualitária e que depende do próprio posicionamento do indivíduo face ao todo social e do modo como este integra, ou não, aquele, não é nova, muito menos recente. A ideia de que a integridade do sistema jurídico, social e político depende do controlo do risco e da insegurança e que isso exige a sujeição 
dos indivíduos à lei e à justiça, bem como o extirpar dos elementos que não se submetem à legalidade, pode divisar-se já na antiguidade clássica. Os delinquentes que, depois de sofrerem o efeito preventivo e dissuasor das penas, ainda assim não partilhassem dos valores comummente aceites na polis deveriam ser dela apartados e tratados no âmbito de um sistema diferenciado de justiça, marcado por uma supressão da sua dimensão de cidadão e tratado como um «inimigo». A génese do «direito penal do inimigo» pode, então, encontrar-se nas concepções político-jurídicas da escola sofista, de pendor fortemente positivista e utilitarista. ${ }^{38}$

Também na filosofia cristã da idade média, através da doutrina de S. Tomás de Aquino, fortemente influenciado pelo pensamento de Aristóteles, se pode divisar a ideia do criminoso como «inimigo» da comunidade, objecto da acção do Estado e da justiça. Vendo no crime um pecado, S. Tomás de Aquino, não é, no entanto, tão radical como S. Agostinho, que via a natureza humana como naturalmente pecadora. A interpretação tomista é a de que o pecado é um desvio susceptível de correcção e arrependimento. O Homem pode reconciliar-se com Deus através da expiação do mal. ${ }^{39}$ Sendo a justiça terrena uma prerrogativa do Estado, compete a este conduzir e refrear as condutas humanas através da imposição coerciva da lei, no sentido de compelir os indivíduos a agir segundo os valores da justiça, característica dos homens virtuosos. A proscrição do indivíduo face à sociedade seria, pois, necessária, quando este não se pautasse por aqueles valores e prejudicasse, assim, o bem comum. De qualquer modo, a noção de que o criminoso deve ser aniquilado pela sua iniquidade, não implica o seu tratamento desigual face ao homem justo. Em boa razão, o pensamento tomista não pode justificar qualquer funcionalismo penal tendente ao tratamento desigual do criminoso, extinguindo-lhe direitos, até porque, na filosofia tomista, o homem é um ser naturalmente sociável, sendo a sociedade política um factor conatural à natureza humana. ${ }^{40}$

\section{Iluminismo absolutista: o criminoso como inimigo do Estado}

38 Cfr. Luís CABRAL DE MONCADA, Filosofia do Direito e do Estado, Vol. I, Coimbra Editora, Coimbra, 2. ed., 1955, p. 14; Luís GRACIA MARTÍN, El Horizonte del Finalismo..., cit., pp. 94 e ss. Manuel M. GUEDES VALENTE, Direito Penal do Inimigo e o Terrorismo, 2. a ed., Almedina, Coimbra, 2017, pp. 42 - 43. O sofisma do "Anónimo de Jâmblico" é, justamente, expressão desta idiossincrasia.

39 Cfr. Luís CABRAL DE MONCADA, Filosofia do Direito e do Estado..., cit., pp. 76 - 77; Manuel M. GUEDES VALENTE, Direito Penal do Inimigo e o Terrorismo..., cit., pp. 44 e 45.

40 Cfr. J. J. CHEVALIER; Y. GUGHET, As Grandes Obras Políticas de Maquiavel à Actualidade, Europa-América, Lisboa, 2004, p. 63. 
Foi a filosofia penal moderna que trouxe o conceito de «inimigo» para a teoria penal. Durante os sécs. XVIII e XIX fizeram curso teorias penais baseadas no contratualismo ${ }^{41}$, segundo as quais o indivíduo, ao violar as normas jurídicas, estaria a violar o contrato que firmou com os demais cidadãos, pelo que haveria de ser intervencionado de modo a reentrar no âmbito do pacto. Numa dimensão ética e política, o indivíduo que não se rege pelo Direito não tem lugar na sociedade porque ameaça a ordem, a estabilidade e até mesmo a sobrevivência do próprio Estado. Como tal, perde as prerrogativas de cidadania, sendo-lhe aplicável um outro estatuto jurídico-político, o de «inimigo da sociedade», ao qual não se reconhecem direitos, liberdades e garantias ${ }^{42}$. Para ROUSSEAU, os delinquentes que cometem crimes graves colocam em causa o contrato social como ordem política oposta à sociedade civil desigual, emergente dos movimentos sociais da modernidade. O contrato social é um compromisso político agregador e socialmente fundante de uma igualdade efectiva entre os homens. Como tal devem ser considerados inimigos e, nessa condição, subtraídos à cidadania. ${ }^{43}$ Para ROUSSEAU, o cidadão é aquele homem que, usando da sua razão natural, enforma uma sociedade votada ao bem comum ${ }^{44}$. Se não podem ser considerados cidadãos, são elementos nocivos, que devem, pura e simplesmente, ser obliterados.

A proto-teoria do «direito penal do inimigo» de JAKOBS podemos encontrá-la na diferenciação entre cidadão e inimigo defendida por HOBBES. Este jusfilósofo, precursor do absolutismo, distingue entre dois estados do indivíduo: o estado legal, em que ele se torna cidadão, e o estado de natureza, no qual o indivíduo não se pauta por imperativos éticos, jurídicos e políticos de convivência social. Como tal, o estatuto político-jurídico a dispensar aos dois estados é, necessariamente, diferenciado: ao estado legal corresponde o estatuto de cidadão; ao estado-natureza corresponde o estatuto de inimigo. ${ }^{45} \mathrm{Na}$ sua obra Leviatã, HOBBES opera a separação entre os dois estados, defendendo a aplicação de um direito penal para o cidadão e um outro para o inimigo. Tal concepção radica na convicção de que o Homem não é um ser sociável na sua natureza, ou seja, no estado de natureza não pode conviver pacificamente nem construir uma comunidade política estável. ${ }^{46}$ É no sentido de

41 Cfr. Günter JAKOBS; Manuel CANCIO MELIÁ, Derecho Penal del Enemigo, Cuadernos Civitas, Madrid, 2003, pp. 28-29.

42 Cfr. Kai AMBOS, Derecho Penal del Enemigo, in: Derecho Penal del Enemigo, Vol. I, MELIÁ; GOMEZ-JARA DIÉZ (coord.), Edisofer, Madrid, 2006, pp. 122 e ss.

43 Cfr. Luís CABRAL DE MONCADA, Filosofia do Direito e do Estado..., cit., pp. 231 e ss.; Luís GRACIA MARTÍN, El Horizonte del Finalismo..., cit., p. 101; Manuel M. GUEDES VALENTE, Direito Penal do Inimigo e o Terrorismo..., cit., p. 47.

44 Cfr. Alain TORRAINE, Crítica da Modernidade, Piaget, Lisboa, 1994, pp. 33 e ss.

45 Cfr. Manuel M. GUEDES VALENTE, Direito Penal do Inimigo e o Terrorismo..., cit., pp. 52 e 53. Vide, tb., Arthur KAUFMANN, Filosofia do Direito, 5. ${ }^{a}$ ed., Fundação Calouste Gulbenkian, Lisboa, 2014, p. 37 e 209 e ss.

46 Cfr. Hamilton SERRA DE CARVALHO. Estado Forte - Hobbesianismoe Maquiavelismo na Ordem Político-Constitucional Global, Chiado Editora, Lisboa, 2016, pp. 51-52. 
contrariar o estado de natureza que HOBBES defende a construção de um Estado forte, de cariz absolutista ${ }^{47}$, onde o monarca é o detentor do poder legislativo e punitivo ${ }^{48}$. Um Estado agregador das legitimidades e liberdades individuais, capaz de, através de princípios racionalistas de actuação, condicionar os indivíduos ao estado legal, único garante da harmonia e estabilidade sociais. Esta transferência para o Estado de uma certa dimensão do arbítrio individual opera a substituição da incerteza e do risco beligerante decorrente do egoísmo individualista do estado de natureza, pela liberdade e segurança garantidos pela obediência à lei, forjada nos moldes do naturalismo antropológico ${ }^{49}$. Só o Estado, como contrato firmado entre os indivíduos que, por receio mútuo de aniquilação (a paixão, que não a razão), se comprometem entre si, é garante da paz, da segurança e da confiança. Sendo esta a tarefa fundamental do Estado, o poder punitivo deste só se encontra limitado na medida em que houver possibilidade de conduzir o indivíduo ao estado legal, ou seja, aplica-se, nessa hipótese, o direito penal do cidadão, cujos limites estão fixados na própria lei. Caso contrário, ao indivíduo que se revele indissociável do estado de natureza, aplica-se-lhe o direito penal do inimigo (direito penal bélico), pois que ao inimigo não se lhe aplica um castigo, mas a simples hostilidade ${ }^{50}$. Este é o ideário do Estado absoluto preconizado por HOBBES no sentido de garantir a estabilidade do "pacto social constitutivo do corpo político do Estado", o qual, por sua vez, seria o garante último do pacto de obediência às leis naturais, pilar da coexistência humana.

Destarte, como dissemos, é nas prerrogativas do Leviatã de HOBBES que JAKOBS buscou inspiração para a sua concepção funcionalista do «direito penal do inimigo», pois que, ao assumir-se que o poder punitivo do soberano só é balizado por limites legais quando recai sobre o cidadão, significa que, ao «inimigo», não são reconhecidos os mesmos direitos nem, tão pouco, as mesmas garantias penais. Mas também a filosofias de KANT e de LOCKE influenciaram fortemente a doutrina de JAKOBS. KANT contribui para a concepção do inimigo como aquele indivíduo que, por orientar a sua conduta num estado de natureza, marcado pelo conflito, o egoísmo e a confrontação, constitui uma ameaça permanente à segurança jurídica, física e cognitiva da sociedade (estado de guerra). Só num contexto em que os indivíduos vivem em estado de legal é possível afastar a ameaça e a insegurança. ${ }^{51}$ O estado legal é, portanto, o único garante de um estado de paz. Para KANT, há que instituir

47 Cfr. Luís CABRAL DE MONCADA, Filosofia do Direito e do Estado..., cit., p. 172. Alain TORRAINE, Crítica da Modernidade..., cit., p. 29.

48 Cfr. Diogo FREITAS DO AMARAL, História das Ideias Políticas, Almedina, Coimbra, 1999, p. 153.

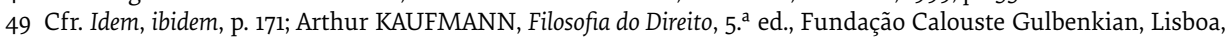
2014, p. 275.

50 Cfr. Luigi FERRAJOLI, Democracia y Garantismo, Trotta, Madrid, 2008, p. 241.

51 Cfr. Emmanuel KANT, A Paz Perpétua e outros Opúsculos, trad. Artur Mourão, Edições 70, Lisboa, 1989, pp. 126 e ss. 
o estado de paz, através da legalidade e da força normativa das leis, cuja violação determinaria que o criminoso fosse visto como se situando no estado de natureza ou, quando muito, como alguém que se desviou do estado legal. Neste último caso, o infractor seria obrigado, por aplicação de penas, a reintegrar-se no estado legal, cujos dispositivos haveria de cumprir por imperativo categórico. Todo aquele que o recusasse ou não fosse permeável aos efeitos ressocializadores, seria visto como um inimigo, alguém que nega o estado de paz, uma fonte de ameaças permanentes à ordem e à segurança pública. Aquele que se encontrasse $a b$ initio no estado de natureza, seria completamente excluído. Todavia, KANT, ao contrário de HOBBES, defendia que a pena a aplicar, no sentido da reposição do estado legal, deveria estar sujeita a critérios de pura legalidade e igualdade na aplicação de lei penal. Para KANT, o estatuto jurídico-político do inimigo não pode resultar da vontade do soberano, mas sim da tipicidade legalmente instituída.

LOCKE, embora também ele contratualista ${ }^{52}$, diverge de ROUSSEAU ao defender o individualismo como base de construção social ${ }^{53}$. Diverge, também, de KANT e de HOBBES. Para o filósofo, o homem não necessitaria de transitar para o estado legal, pois que a própria natureza humana é imbuída de preceitos jusnaturais que orientam a conduta do homem à auto-preservação e à sã convivência, embora o Homem seja dotado de livre arbítrio. A natureza humana tem, ela própria, um estado legal. Ao contrário de HOBBES, que defendia que o estado de natureza humano era um bellum omnium contra omnes ${ }^{54}$, LOCKE preconizava que o estado de natureza era um estado de liberdade individual e de igualdade, cabendo ao Estado, decorrente do contrato social, garantir o bem público e controlar as paixões exacerbadas dos indivíduos ${ }^{55}$. Para HOBBES, para quem o Estado era uma resposta ao estado de natureza, os indivíduos alienam, mediante o contrato social, a sua legitimidade e todos os seus direitos a um ente supra-individual, no sentido de este impor o estado legal e assim se atingir o estado de paz. Esta ideologia deu origem ao conceito absolutista de Estado: o estado de polícia. Já LOCKE, no que foi seguido por Rousseau, Kant, Montesquieu, Beccaria, etc., o indivíduo possui certos direitos inalienáveis, como a liberdade pessoal, para a melhor protecção dos quais aliena um pouco da sua legitimidade política em favor do Estado, sendo este uma resposta ao estado de guerra, não sendo, pois, este admissível por antitético face à natureza humana ${ }^{56}$. Os conceitos de estado de natureza e de contrato social fundam, para LOCKE, um Estado de Direito, liberal e mínimo.57 Todavia, LOCKE sabia que, mesmo no

52 Cfr. Alan TORRAINE, Crítica da Modernidade, Piaget, Lisboa, 1994, p. 68.

53 Cfr. Idem, ibidem.

54 Cfr. Idem, p. 67.

55 Luís CABRAL DE MONCADA, Filosofia do Direito e do Estado..., cit., pp. 212 e 213.

56 Cfr. Alan TORRAINE, Crítica da Modernidade..., cit., p. 67.

57 Luis CABRAL DE MONCADA, Op. cit., pp. 214 e 215. 
estado de natureza como ele o preconizava, o indivíduo poderia adoptar comportamentos de ruptura, desobedecendo às leis naturais que regem a conduta humana. Quando assim fosse, o indivíduo subtrair-se-ia, ele próprio, à comunidade e sujeitar-se-ia a ser tratado como um elemento nocivo. Aqui, a liberdade que assiste aos restantes indivíduos da comunidade para punir ou aniquilar o outsider é bastante mais ampla do que aquela que resulta da lei aplicável aos que não são inimigos da comunidade politicamente organizada, sendo estes aqueles infractores pontuais sem, contudo, se mostrarem hostis aos valores instituídos.

Um dos autores que levou mais longe a ideia do criminoso como «inimigo da sociedade» foi FICHTE, um dos precursores do idealismo alemão. Fortemente influenciando por Kant, o autor defende a objectivização total daquele que, violando gravemente um bem jurídico de grande valor social como a vida, rompe o pacto social, extingue a relação jurídica com o Estado. Partindo do exemplo do homicida, para FICHTE, o criminoso grave deve ser totalmente reificado ao ponto de ser desprovido de quaisquer direitos ${ }^{58}$. Destarte, a sua vida está à inteira disposição do Estado que o pode executar a título de medida de segurança, sendo, não obstante, tarefa do mesmo Estado, garantir que o indivíduo não atinge este estádio de anomia, através do controlo efectivo sobre o quadro comportamental. A morte do criminoso não é uma pena, conquanto este se apresente como incorrigível. É uma medida de gestão com vista à pacificação social. Contudo, FICHTE não preconiza esta solução para toda a criminalidade, sem distinção, porquanto considera que nem todos os crimes são susceptíveis de operar a ruptura da relação Estado-indivíduo-sociedade. Para os crimes de menor gravidade, propõe o autor que, através da aplicação de uma pena, se proponha a regeneração política do infractor através de um contrato de expiação.

Embora a idiossincrasia dos contratualistas tenha tido a virtualidade de lançar as bases da teleologia preventiva especial do direito penal, na verdade, a única preocupação era a integridade do sistema político e jurídico, vista, do ponto de vista sociológico, como essencial à vigência e funcionamento do contrato social.

\section{O garantismo humanista}

Em finais do séc. XVIII, o absolutismo entra em colapso e, com ele, também a ideia de que o Estado está legitimado a actuar repressivamente contra qualquer ameaça à segurança, à ordem pública e à paz jurídica. O direito penal é, agora, concebido como um direito votado

58 Cfr. Günter JAKOBS; Manuel CANCIO MELIÁ, Derecho Penal del Enemigo, Cuadernos Civitas, Madrid, 2003, pp. 28 e ss.; Germán ALLER, El Derecho Penal del Enemigo y La Sociedad de Conflicto, in: Derecho Penal del Enemigo, Vol. I, MELIÁ; GOMEZ-JARA DIÉZ (coord.), Edisofer, Madrid, 2006, p. 90 e ss.; Manuel M. GUEDES VALENTE, Direito Penal do Inimigo e o Terrorismo..., cit., pp. 48-49. 
à preservação da liberdade individual e à garantia das condições essenciais à existência do ser humano, sendo mandatado com o poder estritamente necessário para o efeito. Assim, o próprio Direito actua como forma de limitar o poder do Estado face ao indivíduo e proteger os interesses fundamentais da comunidade tornados bem jurídico-penais, garantindo, assim, a paz social, bem como o exercício dos direitos fundamentais da pessoa. ${ }^{59} \mathrm{O}$ direito penal herdeiro dos valores do racionalismo humanista é um direito penal de liberdade e de igualdade, tendo surgido como forma de reagir contra as arbitrariedades no exercício do ius puniendi, bem como contra os diferentes tratamentos baseados no status económico e social. Os valores da Revolução Francesa de 1789, corporizados na Declaração dos Direitos do Homem e do Cidadão, bem como na Constituição de 1795, foram transpostos pelo positivismo setecentista para a lei penal. É afirmado o princípio da legalidade, bem como o princípio da igualdade de todos perante a lei. É a partir do pensamento e, principalmente, da obra de BECCARIA que mais influencia a reacção contra a prepotência do Estado absoluto e contra o seu direito penal totalitário e opressivo. ${ }^{60} \mathrm{Se}$, à época, o direito penal visava a manutenção da paz jurídica e da segurança e ordem públicas, não hesitando em usar de todas as medidas de polícia que tal desiderato reclamasse, BECCARIA vem afirmar que a legitimidade de punir do Estado deriva de um pacto social, de um mandato dos cidadãos, e que o indivíduo é dotado de personalidade e dignidade humana, não podendo ser usado como meio para atingir a paz jurídica e a ordem pública. Assim, o ius puniendi apenas é legítimo nos termos desse mandato, cujo alcance é pré-fixado na lei e pelas garantias nela afirmadas, no respeito integral pela dignidade e igualdade do indivíduo perante a lei. O direito penal do iluminismo coloca no centro da discursividade penal a pessoa em situação de igualdade, sem distinções. Não há pode haver lugar a tratamentos diferenciados conforme se está «dentro do contrato» ou fora dele. O direito penal deve reger-se por um paradigma de humanidade, concretizado num sistema que respeite a dignidade da pessoa humana em igualdade ${ }^{61}$. O ideário de BECCARIA constitui, pois, o alicerce do garantismo na relação com o poder do Estado.

Gerou-se, então, a partir dessa base, um direito penal de cunho garantista, de carácter humanista, que se assume como ordem de liberdade e não de repressão. É um direito

59 Cfr. Manuel M. GUEDES VALENTE, Direito Penal do Inimigo e o Terrorismo, 2. ${ }^{\mathrm{a}}$ ed., Almedina, Coimbra, 2017, pp. 18$-19$.

60 Cfr. José de FARIA COSTA, Ler Beccaria Hoje, in: Cesare BECCARIA, Dos Delitos e das Penas, Fundação Calouste Gulbenkian, Lisboa, 1998, p. 8.

61 Cfr. Jorge de FIGUEIREDO DIAS, Direito Penal - Parte Geral..., cit., pp. 35-37; Anabela MIRANDA RODRIGUES. Criminalidade Organizada - Que Política Criminal? In: Direito Penal Económico e Europeu - Textos Doutrinários, Vol. III, IDPEE, Coimbra Editora, Coimbra, 2009, p. 198. Manuel M. GUEDES VALENTE, La Política Crimina y la Criminología en Nuestros Dia. Una Visión Desde Portugal, in: Derecho Penal y Criminología como Fundamento da la Política Criminal. Estudios en Homenaje al Prof. Alfonso Serrano Gómez, Dickinson, Madrid, 2006, pp. 1309-1318. 
mínimo, que só intervém em ultima e extrema ratio. A ordem pública, a paz jurídica e a segurança e tranquilidade são asseguradas através da protecção subsidiária dos interesses fundamentais da comunidade ${ }^{62}$, sendo as penas aplicadas à pessoa com vista à sua reconciliação social e reconstituição da integridade da norma violada ${ }^{63}$. Trata-se, pois, de um modelo penal marcada por três grandes vectores: liberdade (legalidade), carácter instrumental e subsidiário (protecção de bens jurídicos penais em ultima et extrema ratio), actuação retrospectiva, (direito penal do facto), teleologia preventiva das penas (prevenção geral e especial). No essencial, o novo direito penal garantista e humanista abandona a e proscreve a concepção nihilista do infractor como «inimigo» da ordem e da paz pública do absolutismo, para o considerar como um fim em si mesmo, estando o sistema penal sempre comprometido com a sua reintegração social. O criminoso não pode, em caso algum, ser visto como coisa, instrumentalizado por um sistema apenas comprometido com a sua própria integridade, mas sempre como um entidade dotada de direitos e deveres.

Não obstante, o espectro de um direito penal do agente, ao arrepio de um direito penal do facto, nunca desapareceu verdadeiramente. Podemos notá-lo na doutrina de VON LISZT, no que tange à distinção político-criminal e penológica entre criminosos reincidentes, delinquentes habituais e delinquentes por tendências, cuja influência é bem patente no Código Penal Português de 1886. O insigne autor defendia que infractores com estas características, considerados "inimigos fundamentais da ordem social" ${ }^{64}$, deveriam ser sujeitos a penas de duração indeterminada, como forma de controlo comportamental, o que constitui, claramente, um tratamento penológico diferenciado para uma categoria de infractores, embora se possa considerar, com GUEDES VALENTE ${ }^{65}$, que se trata, ainda assim, de uma discriminação em função da maior dificuldade de ressocialização que tais sujeitos denotam e que o fim último de tal reforço sancionatório é, ainda e sempre, a sua recuperação social e não a sua inocuização. ${ }^{66}$

Foi em pleno séc. XX que a noção de «inimigo» inspirou, como nunca antes, um sistema jurídico concreto. O nacional-socialismo do III Reich adoptou um sistema penal totalitário, absoluto e repressivo, usado como instrumento de terror, através do qual procurou eliminar todos aqueles que, por razões de ascendência geográfica, etnia, confissão religiosa ou ideologia fossem considerados inimigos do Estado, por, alegadamente, representarem para este uma ameaça à respectiva estabilidade. Obliterando por completo o princípio da

62 Cfr. José de FARIA COSTA, Ler Beccaria Hoje, cit., p. 24.

63 Cfr. Manuel M. GUEDES VALENTE, Direito Penal do Inimigo e o Terrorismo, cit., pp. 70-71.

64 Luís GRACIA MARTÍN, O Horizonte do Finalismo..., cit., p. 120.

65 Cfr. Manuel M. GUEDES VALENTE, Direito Penal do Inimigo..., cit., p. 59.

66 Todavia, podemos antever no Código Penal de 1886 laivos de uma concepção de «inimigo» social nas medidas de segurança pré-delituais aplicáveis a imputáveis. 
legalidade e da tipicidade estrita de crimes e penas, o sistema penal nazi aplicava penas de forma arbitrária, desconsiderando, também, totalmente, o princípio da igualdade. Foi, assim, um claro e espectacularmente assustador exemplo de funcionalização securitária de um sistema penal. Assentando na doutrina de MEZGER, fortemente inspirado por HEIDEGGER, o direito penal do III Reich ${ }^{67}$ constitui o mais acabado exemplo de uma concretização efectiva de um «direito penal do inimigo» levado ao extremo. No seu âmbito, operou-se uma completa despersonalização do arguido, o qual é despido da sua condição humana, sendo tratado pelo Estado como simples res. Por outro lado, a experiência do Holocausto mostrou-nos como um sistema penal baseado na teoria do «inimigo» pode ser utilizado como instrumento de aniquilação, sob o manto legitimador da lei.

Consequência da experiência das duas Grandes Guerras, o cariz garantista do direito penal acentuou-se, ganhou novo fôlego na 2. ${ }^{a}$ metade do séc. XX, na sequência da experiência adquirida nas duas Grandes Guerras. O jusnaturalismo triunfou definitivamente sobre as teorias do positivismo exasperado de inspiração cartesiana e kantiana, que conduziram ao «estado de legalidade» e à coisificação da pessoa através de sistemas jurídicos totalitários comprometidos com a tutela exacerbada e absolutista ${ }^{68}$ de bens jurídicos supra-individuais e colectivos, usando o direito penal como instrumento securitário. O agente de crimes deixa de ser visto como um inimigo do sistema, um indivíduo em «estado de natureza», para ser perspectivado em toda a sua dignidade de ser humano. Isto por força de dois marcos históricos em matéria de direitos humanos e estatuto da pessoa na relação com o Estado: a Declaração Universal dos Direitos Humanos e a Convenção Europeia dos Direitos Humanos. As sociedades reagiram à tentativa de transformar o direito penal num instrumento de segurança através da submissão da cidadania ao interesse difuso da ordem social e da paz jurídica, impondo que, nos textos constitucionais, figurassem um conjunto de garantias fundamentais da pessoa contra o puder punitivo do Estado, garantias materiais e processuais inarredáveis e sujeitas a limite de revisão constitucional.

Surge, então, o direito constitucional penal (ou Constituição penal) com um alcance muito próximo do conteúdo da Declaração Universal dos Direitos Humanos. Como diz GUEDES VALENTE, "inverte-se a protecção da segurança cognitiva" ${ }^{69}$ : o «inimigo» deixa de ser o indivíduo infractor, que constituía uma ameaça para a integridade do Estado e para a percepção de segurança da comunidade, para ser o próprio Estado o novo «inimigo», contra

67 Não é, de resto, exemplo único. Os sistemas penais dos regimes totalitários de inspiração socialista-marxista também são/eram baseados no conceito de «inimigo» do Estado e, portanto, a sociedade. Tais sistemas penais eram autênticos instrumentos de controlo político e social.

68 Tomamos a expressão de Manuel M. GUEDES VALENTE (Direito Penal do Inimigo..., cit., p. 73).

69 Manuel M. GUEDES VALENTE, Direito Penal do Inimigo..., cit., p. 73. 
cujo poder abusivo há que defender o cidadão através de um programa penal e processual penal garantista e humanista, capaz, não só de proteger os valores essenciais à subsistência social, mas também de ressocializar o infractor no estrito respeito pela sua dignidade do ser humano. "O baluarte da dignidade da pessoa humana impõe aos estados que tratem os seus membros (...) como seres humanos, depositários de direitos, liberdades e garantias penais materiais, processuais e penitenciárias."70

Através do pensamento de autores como FERRAJOLI ${ }^{71}$, começa, então, a desenvolver-se, aquilo que usa chamar-se «direito penal do cidadão», por oposição ao «direito penal do inimigo», um direito penal assente nos valores da dignidade humana e da liberdade pessoal, ordenado à protecção subsidiária e fragmentária de bens jurídicos penais e à prevenção especial positiva, posto em prática por um processo penal atribuidor de garantias processuais de ampla defesa e respeito pelos direitos fundamentais do arguido. A pena só faz sentido pela prática de um facto típico, socialmente desvalioso e censurável ao agente, dentro do quadro axiológico constitucional e dos direitos, liberdades e garantias ali consagrados. "O direito penal do cidadão exige que se olhe para o direito penal como um direito de liberdade, e para o direito processual penal como o direito, por excelência, dos inocentes." ${ }^{2}$

\section{O funcionalismo securitário: a crise do humanismo penal}

Não obstante o paradigma do «direito penal do cidadão» se tenha institucionalizado e estabilizado até ao fim do séc. XX, a verdade é que, com o fim do século, novos desafios se lhe colocam. Os «grandes e novos riscos» emergentes na sociedade pós-industrial, pós-moderna e globalizada, que BECK chamou de «sociedade do risco» ${ }^{73}$, trouxeram a incerteza e o medo à sociedade e, assim, provocam sentimentos generalizados de insegurança ${ }^{74}$. A ubiquidade e imprevisibilidade dos riscos ${ }^{75}$, a noção da falência da técnica instrumental calculadora pela complexidade e incontrolabilidade das novas fontes de perigo, como a manipulação genética, a indústria bioquímica e, principalmente, a maior visibilidade do

70 Cfr. idem, ibidem.

71 O insigne autor defende que o direito penal humanista é aquele que, não só atribui um conjunto de garantias essenciais ao indivíduo que lhe permitem defender-se contra o exercício do poder de punir do Estado, como também promove activamente a integridade a aplicação dessas garantias. Cfr. Luigi FERRAJOLI, Derecho y Razón.

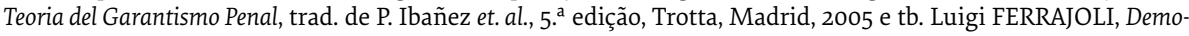
cracia y Garantismo, Trotta, Madrid, 2008.

72 Manuel M. GUEDES VALENTE, Direito Penal do Inimigo..., cit., p. 74.

73 Ulrich BECK, La Sociedade del Riesgo. Hacia una Nueva Modernidad, Paidós, 1998. Vide, tb., Idem. La Sociedad Del Riesgo Mundial: En busca de la seguridad perdida, Paidós, Barcelona, 2008; Idem. La Sociedad Del Riesgo Global, Siglo XXI de España Madrid, 2002.

74 Cfr. Manuel M. GUEDES VALENTE, ibidem, p. 76; Juarez TAVARES. A Globalização e os Problemas de Segurança Pública, in: Revista da Associação Brasileira de Professores de Ciências Penais, São Paulo, ano 1, n. ${ }^{\circ}$ oo, 2004.

75 Cfr. Augusto SILVA DIAS. Protecção Jurídico-Penal dos Interesses dos Consumidores, 3 . $^{\mathrm{a}}$ ed. polic, FDUC - IDPEE, Coimbra, 2001, p. 7 . 
fenómeno do terrorismo, são factores que criam nas comunidades novas e desconhecidas sensações de perigo, impotência e pânico e, por isso, dão origem a novos estados de alerta. Podemos, então dizer que a "criminalidade e [o] medo da criminalidade marcam a contemporaneidade." ${ }^{76}$ A recente percepção dos custos da globalização e da real ameaça da criminalidade organizada, fizeram erguer a bandeira do combate cerrado a esse fenómeno, a qual tem servido de argumento de marketing político, incutindo na sociedade a ideia de que o garantismo é um obstáculo à eficácia desse combate e de que vale a pena sacrificar certas garantias para, assim, afirmar a segurança e a tranquilidade públicas ${ }^{77}$. Deste modo, a política criminal tende a transformar-se numa política de «segurança». Não obstante, as cada vez mais complexas e organizadas redes de criminalidade transnacional tornam exponencialmente mais difícil a descoberta do ilícito e dos seus agentes. A danosidade social deste tipo de criminalidade é elevada, principalmente tendo em conta que se entrecruza com o poder económico e político, o que gera ainda desconfiança e descrença no aparelho de Estado, na bondade das leis e, muito particularmente, no poder judicial, cuja acção é, para muitos, cerceada pelo excessivo garantismo do processo penal.

A pós-modernidade, que BAUMAN expressivamente apelidou de "modernidade líquida"78, é um tempo de perda de referentes, de integração, fusão e erosão cultural no plano do imediatismo. Uma sociedade de consumo acrítica, voltada para o edonismo e sem objectivos reais. Uma sociedade que perdeu a utopia e não projecta o futuro. Uma sociedade dominada pelos mercados, pelas estatísticas e índices, marcada por uma forte desregulamentação fruto do recuo do Estado Social. Esta realidade cria no indivíduo uma forte percepção de incerteza e insegurança, pela mutabilidade constante dos referentes. FARIA COSTA chama a atenção para a actual crise da ética, do direito penal e da percepção da realidade, a qual convive com a uma aceitação do "absolutismo do global"79.

A confiança num direito penal liberal, subsidiário, mínimo e fragmentário para o combate eficaz à nova criminogénese é cada vez mais abalada ${ }^{80}$, o que tem aberto novos espaços a discursos populistas, radicais e securitários, mas que vão ao encontro dos medos e das incertezas das comunidades, ávidas de percepção de segurança. Estes discursos, propala-

76 Anabela MIRANDA RODRIGUES, Política Criminal - Novos Desafios, Velhos Rumos, in: Direito Penal Económico e Europeu - Textos Doutrinários, III vol., IDPEE, Coimbra Editora, Coimbra, 2009, p. 160.

77 Cfr. Winfried HASSEMER, A Segurança Pública no Estado de Direito, AAFDL, 1995, pp. 269 e ss.

78 Cfr. Zygmunt BAUMAN. Modernidade Líquida, Zahar, Rio de Janeiro, 2001.

79 Cfr. José de FARIA COSTA, A Criminalidade em um Mundo Globalizado: ou Plaidoyer por um Direito Penal Não Securitário, in: Direito Penal Económico e Europeu - Textos Doutrinários, Vol. III, IDPEE, Coimbra Editora, Coimbra, p. 113.

80 Cfr. Mário FERREIRA MONTE. O Futuro tem Direito Penal? O Direito Penal tem futuro? Apontamento introdutório à obra de Paulo S. FERNANDES, Globalização, "Sociedade de Risco" e o Futuro do Direito Penal, Almedina, Coimbra, 2001; Luís GRACIA MARTIN, El horizonte del finalismo y el derecho penal del enemigo, Tirant Lo Blanch, Valencia, 2005, pp. 127-129; 
dos, em regra, pelos novos leviatãs do séc. XXI, recuperam o recurso a sistema de repressão e antecipação da tutela penal, como são os casos dos programas de "tolerância zero", de "lei e ordem" ${ }^{1}$, simples abandono de uma perspectiva preventiva pós-delitual em favor de soluções securitárias de deterrence, funcionalizadas ao único objectivo de favorecer a segurança cognitiva dos seus eleitores através do asseguramento da integridade do sistema. Avançam-se, para o efeito, promessas de flexibilização de categorias dogmáticas do direito penal, desformalização de princípios, erosão de garantias materiais e processuais legitimadas por discursos de ódio, xenofobia e racismo contra um suposto inimigo comum: o criminoso. É aquilo que FERRAJOLI denomina de "terrorismo penal", ou seja, numa inversão de valores: terrorismo não é uma qualidade dos factos combatidos, mas sim a própria actuação repressiva do sistema, cuja estratégia já não é a actuação preventiva em relação aos factos, mas pura e simplesmente suprimir os possiveis autores ${ }^{82}$. FARIA $\operatorname{COSTA}^{83}$ denomina esta tendência de glorificação do Estado punitivo. Quer-se menos Estado social e menos Estado regulador e intervencionista, mas requer-se mais Estado punitivo. Novamente, como no absolutismo, a ordem pública, a percepção de segurança e a tranquilidade das populações são valores macrossociais que tendem a ocupar o lugar do bem jurídico como critério legitimador da intervenção penal. ${ }^{84}$ É a concretização do "império do medo" de BARBER ${ }^{85}$. Esta tendência tem-se demonstrado mesmo ao nível das instituições internacionais e do direito supra-estadual, onde se tem instalado um discurso intolerante ${ }^{86} \mathrm{e}$ «belicista», marcado por palavras de ordem como "luta", "combate", "tolerância zero". ${ }^{87}$ É assim que, fruto do desenvolvimento da sociedade de comunicação aberta e global ${ }^{88}$, faz actualmente curso uma política criminal populista baseada em percepções empíricas, segundo a qual, sem Estado

81 Cfr., a propósito, com muito interesse, André LAMAS LEITE, Nueva Penologia, Punitive Turn y Derecho Penal: Quo Vadimus? Por la Incertidumbre (Pos) Moderna, in: InDret - Revista para el analisis del Derecho, nr. 2, Barcelona, 2013.

82 Cfr. Luigi FERRAJOLI, Democracia y Garantismo, Trotta, Madrid, 2008, p. 237.

83 Cfr. José de FARIA COSTA, A Criminalidade em um Mundo Globalizado: ou Plaidoyer por um Direito Penal Não Securitário, in: Direito Penal Económico e Europeu - Textos Doutrinários, Vol. III, IDPEE, Coimbra Editora, Coimbra, p. 114.

84 Cfr. José DIÉZ RIPOLLÉS, El Nuevo Modelo Penal de la Seguridad Ciudadana, in: Revista Electrónica de Ciencia Penal y Criminología (RECPC) 06-03, 2004. Vide tb. José DÍEZ RIPOLLÉS, De la Sociedad del Riesgo a la Seguridad Ciudadana: Un Debato desenfocado, in: Revista Electrónica de Ciencia Penal y Criminología (RECPC), 07-01, 2005.

85 Cfr. Benjamin BARBER, Fear's Empire: War, Terrorism and Democracy, W. W. Worton, New York, 2003.

86 Sobre esta tendência actual para um endurecimento das políticas criminais vide Paulo MOTA PINTO. Nota sobre o 'imperativo da tolerância' e seus limites, in Estudos em Memória do Conselheiro Luís Nunes de Almeida, Coimbra Editora, Coimbra, 2007; Luis Nunes de ALMEIDA. Tolerância, Constituição e Direito Penal, in: Revista Portuguesa de Ciências Criminais, Coimbra Editora, Coimbra, 2013, ano 13, n. ${ }^{\circ}$.

87 Pedro CAEIRO, Cooperação Judiciária na União Europeia, in: Direito Penal Económico e Europeu: Textos Doutrinários, Vol. III, Coimbra Editora, Coimbra, 2009, p. 76 ; José de FARIA COSTA, A Criminalidade em um Mundo Globalizado: ou Plaidoyer por um Direito Penal Não Securitário, in: Direito Penal Económico e Europeu - Textos Doutrinários, Vol. III, IDPEE, Coimbra Editora, Coimbra, p. 118.

88 Cfr. Winfried HASSEMER, Op. Cit., p. 269 e ss. 
punitivo, triunfará a criminalidade ${ }^{89}$. O direito penal, tradicionalmente perspectivado como um «direito de liberdade» vê-se cada vez mais confrontado com uma demanda por um sentimento de segurança, principalmente em face da percepção da ameaça do terrorismo, o qual conseguiu "gerar a incerteza da segurança em qualquer lugar e em qualquer minuto e promover a paneonomia emergente da teoria do perigo terrorista." ${ }^{90}$ A atitude social face à intervenção penal altera-se: de um direito penal garantista, as sociedades passam a clamar por um direito penal funcionalista. Um funcionalismo sistémico: por um lado, repressivo, capaz de conter a onda de violência da propalada ameaça terrorista. Por outro, modernizado, tecnológico, orientado a um fim: combater a ameaça da criminalidade organizada ${ }^{91}$. Trata-se de um sistema autopoiético, que elege o seu próprio objecto, método e finalidades, instrumento da realização de políticas criminais de cunho belicista próprias de um Estado de segurança..$^{22}$ A doutrina do Estado de segurança propõe a substituição da lógica liberal do direito à liberdade e segurança contra o Estado, por uma outra que propugna o direito à liberdade e segurança através do Estado (e como tarefa fundamental deste), recuperando, no fundo, o ideário de HOBBES e de LOCKE. É ROBBERTS quem propugna a ideia de que o indivíduo tem, perante o Estado, o poder de reclamar a protecção e promoção de um direito fundamental à segurança. Foi todavia ISENSEE que melhor formulou a ideia do direito à segurança, concebendo-o a partir da dialéctica liberdade-segurança e exprimindo a ideia de a segurança mais não é do que a liberdade defendida. ${ }^{93}$

Ao nível processual, existe claro dissenso entre os defensores de um modelo diferenciado para combater a criminalidade organizada e os que não aceitam essa via. Na verdade, vão ganhando espaço teorias que propugnam um paradigma processual diferenciado para o combate à criminalidade organizada e ao terrorismo, tendo como base o entendimento de que as soluções legais "se devem adequar aos contextos de actuação do comportamento intoleravelmente desviado"94. Estas teorias, de que é exemplo a doutrina de SCHÜNEMANN e, de um modo mais extremo, o Patriot Act norte-americano, defendem uma flexibilização das garantias político-criminais, substantivas e processuais ${ }^{95}$, ou seja, uma revisão das regras que limitam a acção da investigação criminal na descoberta da verdade mate-

89 Cfr. José de FARIA COSTA, A Criminalidade em um Mundo Globalizado..., cit., p. 115.

90 Manuel M. GUEDES VALENTE, Op. cit., p. 81.

91 Cfr. Anabela MIRANDA RODRIGUES, Política Criminal..., cit., p. 163.

92 Cfr. DENNINGER, Der Prävenstionsstaat, apud Maria Margarida SILVA PEREIRA, Direito Penal - Direito do Risco, Comparticipação Crimininosa, Tráfico de Influência, Quid Iuris, Lisboa, 2012, p. 19.

93 Cfr. Maria Margarida SILVA PEREIRA, Op. cit., p. 20.

94 Bernd SCHÜNEMANN, Consideraciones críticas sobre la situación espiritual de la ciencia jurídico-penal alemana, in: Annuario de Derecho Penal y Ciencias Penales, n. ${ }^{\circ}$ 49, fasc. 1, Jan. - Abril, San Bernardo, Madrid, 1996, pp. 202 e ss.

95 Cfr. José de FARIA COSTA, O Fenómeno da Globalização e o Direito Penal Económico, in: Direito Penal Económico e Europeu - Textos Doutrinários, Vol. III, Coimbra Editora, Coimbra, 2009, p. 107. 
rial, com especial relevo para os meios de obtenção de prova ${ }^{96}$, com óbvio prejuízo para os valores do Estado de Direito. No caso do Patriot Act, oblitera-se por completo o estatuto de arguido, com todo o prejuízo para os mais elementares direitos fundamentais da pessoa ${ }^{97}$, o que GUEDES VALENTE apelida de "esquizofrenia belicista" 98 . No ordenamento penal português já se assiste, no âmbito da investigação, bem como na restante actividade policial, a uma desjudicialização (até mesmo desjudiciarização) e a uma policializaçãa $0^{99}$ dos actos que contendem com os direitos fundamentais das pessoas ${ }^{100}$, de que pode citar-se, como exemplos, o arts. $177 . .^{\circ}$ n. ${ }^{o}$ s c) e n. $.^{\circ} 3,252 .^{\circ}$-A do Código de Processo Penal e a alínea a) do art. $29 .{ }^{\circ}$ da Lei de Segurança Interna (Lei n. ${ }^{\circ}$ 53/2008 de 29 de Agosto).

Todo este discurso baseia-se na convicção de que o respeito pelos direitos fundamentais é incompatível com a perseguição da criminalidade organizada e encontra eco nas sociedades pós-modernas, nas quais a diminuição da intervenção do Estado social teve como efeito o reforço do clamor pela intervenção punitiva estatal ${ }^{101}$. Neste contexto, o apelo à intervenção socializadora do direito penal sobre o criminoso ou a invocação dos seus direitos fundamentais diz-se serem ideias anacrónicas. Começa a ganhar terreno um certo «pânico moral» conducente a um discurso eficientista de inocuização, um discurso legalista de justiça absoluta e obrigatória, repressiva e potencialmente desumanizante ${ }^{102}$, que guindam o "valor segurança"103 à axiologia suprema do sistema. Uma tal ordem de valores seria assegurada por uma actuação fortemente repressiva, marcada pela antecipação da tutela penal a meros estados de perigosidade, através da punição de actos preparatórios e da identificação de grupos de risco segundo um cálculo actuarial probabilístico (actuarial justice) ${ }^{104}$, fundado na religião, ascendência geográfica, ideologia política ou de outra ordem dos indivíduos. Programas político-criminais de sobrepenalização, como o Law and Order americano, e de

96 Cfr. Bernd SCHÜNEMANN, Consideraciones críticas..., cit., pp. 202 e ss.

97 Cfr. Luigi FERRAJOLI, Op. cit., pp. 237 e ss.; Manuel M. GUEDES VALENTE, Direito Penal do Inimigo..., cit., p. 93.

98 Cfr. Manuel M. GUEDES VALENTE, Op. cit., p. 140 e ss.

99 O termo é de Manuel M. GUEDES VALENTE (Direito Penal do Inimigo..., cit., pp. 89-90).

100 Cfr. Winfried HASSEMER, A Segurança Pública no Estado de Direito, AAFDL, 1995, pp. 90-120.

101 Cfr. Laura ZÚÑIGA RODRIGUEZ, Política Criminal, Colex, Madrid, 2001, p. 266. Sobre as consequências da globalização para a noção de Estado, vide: Peter J. ANDERSON, Política Global do Poder, Justiça e Morte, Piaget, Lisboa, 1998, pp. 103 e ss. José de FARIA COSTA, O Fenómeno da Globalização..., cit., p. 114.

102 Cfr. Anabela MIRANDA RODRIGUES, Política Criminal..., cit., p. 165.

103 Cfr. Idem, ibidem.

104 Cfr. André Lamas LEITE, Nova penologia, punitive turn e direito criminal: quo vadimus? pelos caminhos da incerteza (pós-)moderna, in: Direito Penal - Fundamentos Dogmáticos e Político-Criminais - Homenagem ao Prof. Peter Hünerfeld, Coimbra Editora, Coimbra, 2013, p. 395-476; Vide, ainda, Bernardo del ROSAL BLASCO, Hacia un Derecho Penal de la Postmodernidad?, in: Revista Electrónica de Ciencia Penal y Criminología, 2009, n. ${ }^{0}$ 11-08, p. 8-35. 
hipercriminalização $0^{105}$, como os inspirados na doutrina da «tolerância zero», são demonstração disso mesmo.

Tal programa de actuação abre caminho ao justicialismo ${ }^{106}$, o qual deriva, invariavelmente, na condenação a todo o transe, numa manifestação daquilo que FARIA COSTA apelida de "soberba ética" do Estado punitivo, considerando que aqueles que praticam crimes são eticamente inferiores, colando-lhes esse estigma de tal modo que qualquer ressocialização se assemelha muito improvável ${ }^{107}$

HASSEMER $^{108}$, da Escola de Frankfurt, é muito crítico à expansão e mutação do direito penal, transformando-se num aparelho de repressão comportamental, através da flexibilização, ainda que controlada dos seus princípios reitores e da desformalização da sua dogmática, em ordem a combater os novos fenómenos da instabilidade social e jurídica da pós-modernidade. $\mathrm{O}$ autor considera que a «falência» do sistema penal não pode dado por adquirida e que discursos como o de JAKOBS não estão materialmente sustentados em reais necessidades trazidas pelas insuficiências do direito penal de cunho garantista, herdado do racionalismo humanista. GUEDES VALENTE ${ }^{109}$ aponta que um possível abandono do paradigma penal vigente só se legitimará numa prévia avaliação de todos os múltiplos factores que condicionam a eficácia do sistema penal, desde o acerto das estratégias político-criminais vertidas nas soluções legais, passando pela preparação dos agentes do sistema, até à própria responsabilidade do Estado no cumprimento dos seus programas sociais e económicos.

Se FERRAJOLI ${ }^{10}$ alerta para o facto de que a transformação da segurança colectiva no bem jurídico-penal por excelência pode conduzir à subversão da legalidade democrática, GUEDES VALENTE ${ }^{111}$ alerta para o perigo da sua substituição, a curto prazo, por um Estado de direito autoritário, capaz de proscrever a separação e interdependência de poderes por um autêntico estado-de-polícia. Quer isto dizer que, por exemplo, o enquadramento jurídico-penal do fenómeno do terrorismo, i.e., a tipificação da conduta numa dada facti

105 Fenómeno que se tem concretizado na tipificação penal de condutas outrora, e tradicionalmente, tratadas ao nível do ilícito de mera ordenação social e na expansão descontrolada do catálogo de crimes públicos, de que servem de exemplo os tipos penais previstos no Código das Sociedades Comerciais, nos arts. $509 .^{\circ}$ a $523 .^{\circ} \mathrm{e}$ $526 .^{\circ}$, com a agravante de que o regime premial previsto no art. $527 .^{\circ}$ para tais tipos é muito menos benéfico para o agente do que o previsto no Código Penal para os crimes contra o património em geral.

106 Sobre a actual tendência para o justicialismo penal, vide: Manuel M. GUEDES VALENTE, Direito Penal do Inimigo..., cit., p. 91 e ss.

107 Cfr. José de FARIA COSTA, A Criminalidade em um Mundo Globalizado: ou Plaidoyer por um Direito Penal Não Securitário, in: Direito Penal Económico e Europeu - Textos Doutrinários, Vol. III, IDPEE, Coimbra Editora, Coimbra, p. 121.

108 Cfr. Winfried HASSEMER, A Segurança Pública no Estado de Direito, AAFDL, 1995, pp. 91 e ss.

109 Cfr. M. Monteiro GUEDES VALENTE, Direito Penal do Inimigo..., cit., pp. 77 e ss.

110 Cfr. Luigi FERRAJOLI, Op. cit., p. 250.

111 Cfr. Manuel M. GUEDES VALENTE, Op. cit., pp. 77 e 78. 
species, não pode significar um tratamento dogmático e processual à margem dos preceitos constitucionais vigentes ao nível das garantias fundamentais do arguido ${ }^{112}$. Esse enquadramento há-de ser imbuído do humanismo garantista, por sua vez inspirado na axiologia consagrada na DUDH de 1948, filha da Bill of Rights de 1689 e das Declarações de 1776 e de 1789. Não podemos retroceder à lógica do direito penal do autor através da admissão de uma lógica de sistemas penais paralelos, em que coexistem, em vigência efectiva, direito penal do facto e direito penal do autor. Este último, de pendor niilista, tendente à reificação do agente através da sua despersonalização ${ }^{113}$, da admissão de um estatuto de não-pessoa de que nos fala GRACIA MARTÍN. ${ }^{114}$ Nas palavras de Anabela MIRANDA RODRIGUES: é "o retrocesso a um tempo em que o estranho, o desviante, é um delinquente inimigo e quem está fora do pacto social é alguém contra quem há que lutar."15

Para autores como FREITAS DO AMARAL ${ }^{116}$, a pós-modernidade coloca ao direito penal um desafio: não enveredar por estratégias de deterrence, antes achar um novo equilíbrio entre as necessidades de segurança e o imperativo do respeito pelos direitos fundamentais. Ora, estamos em crer que esse equilíbrio deve ter como referente fundamental a dignidade da pessoa humana ${ }^{117}$. Logo, qualquer estratégia de política criminal deve ter em conta que o Homem é, acima de tudo, um ser livre e que restringir a liberdade (valor da segurança) para garantir a liberdade é um raciocínio antitético quando se esquece a dignidade da pessoa.

Não obstante, na actualidade, "os [...] movimentos de sobrepenalização e de segurança convergem e reforçam-se para fazerem da norma penal e da justiça repressiva o derradeiro baluarte de uma sociedade com falta de referências."118

112 Manuel M. GUEDES VALENTE (Direito Penal do Inimigo..., cit., p. 84) aponta, em particular, os arts. $1 .^{\circ}, 2 .^{\circ}, 9 .^{\circ}$, $18 .^{\circ}, 29 .^{\circ}$ e $32 .^{\circ} \mathrm{da}$ CRP.

113 Cfr. Luigi FERRAJOLI, Democracia y Garantismo, Trotta, Madrid, 2008, p. 237.

114 Cfr. Luis GRACIA MARTÍN, O Horizonte do Finalismo..., cit., p. 132.

115 Anabela MIRANDA RODRIGUES, Política Criminal..., cit., p. 162, Vide, a propósito da recuperação da ideia de «inimigo», Laura ZUÑIGA RODRIGUEZ. Redes Internacionales y Criminalidad: a Propósito del Modelo de Participación en Organización Criminal, in: El Derecho Penal Ante La Globalización, Laura ZUÑIGA RODRIGUEZ; Cristina MENDEZ RODRIGUEZ, M. Rosario DÍAZ-SANTOS (coords.), Colex, Madrid, 2002.

116 Cfr. Diogo FREITAS DO AMARAL, Do 11 de Setembro à Crise do Iraque, Bertrand, Lisboa, 2003, p. 53.

117 Cfr. Chäim PERELMAN. Ética e Direito, Piaget, Lisboa, 2002, p. 360. Escreve o autor: “(...) a pessoa humana possui uma dignidade que lhe é própria e ela merece o respeito enquanto sujeito moral livre, autónomo e responsável. (...) Com efeito, se é o respeito pela dignidade humana que é a condição de uma concepção jurídica de direitos humanos, (...) é preciso admitir como corolário a existência de um sistema de direito com o poder de coagir. (...) $\mathrm{Na}$ falta de impor esse respeito ao próprio poder, este, sob pretexto de proteger os direitos do Homem, corre o risco de se tornar tirânico e arbitrário. Para evitar essa arbitrariedade é, pois, indispensável limitar os poderes de toda a autoridade encarregue de proteger o respeito pela dignidade das pessoas, o que supõe um Estado de Direito e a independência do poder judicial." Chäim PERELMAN, ibidem.

118 François OST, O Tempo do Direito, Piaget, Lisboa, 2001, p. 383. 


\section{Um direito penal para a «sociedade do risco» pós-moderna: ainda o carácter ins- trumental do direito penal?}

A falência e consequente superação da razão técnico-instrumental calculadora na sociedade pós-industrial, conjugada com o emergir de uma «sociedade do risco» coloca o direito penal perante um dilema: persistir na matriz liberal do direito penal mínimo e instrumental ou abandonar o paradigma e substituí-lo por uma nova dogmática jurídico-penal, fundamentada numa política criminal marcada pelo abandono do axioma da finalidade exclusiva de protecção de bens jurídicos em favor de um direito penal de imposição de puras normas de comportamento ${ }^{119}$. O direito penal perderia o seu carácter mínimo e, a coberto de novos programas constitucionais, tornar-se-ia um direito de prima (ou sola) ratio, ou seja, um instrumento de governo social. ${ }^{120} \mathrm{O}$ paradigma penal para a «sociedade do risco» há-de achar-se, pois, algures entre a manutenção dos «monólitos juridicamente corporizados» de que falava RUPP ${ }^{121}$ e a superação total do carácter instrumental do direito penal, funcionalizando-o por completo a uma política criminal de puro controlo e gestão de riscos numa perspectiva de prevenção geral integradora, na qual a efectividade da liberdade é condicionado pelas reais condições de exercício desse direito, o que subordina um direito fundamental às decisões do Estado em termos de oportunidade, nomeadamente em sede de legislação ordinária. ${ }^{122}$

Conceber-se-ia, desta forma, um direito penal perfeitamente autopoiético, à boa maneira do proposto por $\mathrm{HONIG}^{123}$ e ferozmente criticado por MOCCIA ${ }^{124}$.

SILVA DIAS ${ }^{125}$ dá-nos conta de que "as preocupações de segurança desencadearam uma «fuga para o direito penal» que é responsável pelas tendências de sobre-criminalização (...), antecipação da tutela penal, etc." SCHULZ ${ }^{126}$ aponta que aumento da sensação (percepção) de insegurança e uma maior sensibilidade aos riscos potenciados por uma sociedade em contínua e cada vez mais rápida mutação, provocarão uma inexorável expansão das incriminações. O problema que hoje se coloca é, precisamente, o de saber se essa expansão do

119 Cfr. Günter JAKOBS; Manuel CANCIO MELIÁ, Derecho Penal del Enemigo, Cuadernos Civitas, Madrid, 2003, p. 60 e ss.

120 Jorge de FIGUEIREDO DIAS, O direito penal entre a "sociedade industrial" e a "sociedade do risco", in: Estudos em Homenagem ao Prof. Doutor Rogério Soares, BFDUC, Stvdia Ivridica, n. ${ }^{\circ} 61$, Outubro de 2001, p. 597.

121 Cfr. Jorge de FIGUEIREDO DIAS, Op. cit., p. 588.

122 Cfr. Maria Margarida SILVA PEREIRA, Op. Cit., p. 23.

123 Cfr. Manuel da COSTA ANDRADE, Consentimento e Acordo em Direito Penal, Coimbra Editora, Coimbra, 1991, pp. 42 e ss.

124 Cfr. Sérgio MOCCIA. De la tutela de bienes a la tutela de funciones: entre ilusiones postmodernas y reflujos iliberales, in: Política Criminal y Nuevo Derecho Penal (libro homenaje a Claus Roxin), Bosch, Barcelona, 1997.

125 Augusto SILVA DIAS, Protecção Jurídico-Penal do Interesses dos Consumidores, $3 .^{\text {a }}$ ed. policop., FDUC - IDPEE, Coimbra, 2001, p. 5, p. 21. Cfr. Hermínio RODRIGUES, op. cit., p. 22.

126 Lorenz SCHULZ, De la aceleración de las condiciones de vida, in: La Insostenible Situación del Derecho Penal, Comares, Granada, 1999, pp. 447-468. 
direito penal corresponderá à identificação de novos bens jurídicos ou se o direito penal da «sociedade do risco» se transformará num direito totalmente funcionalizado ao controlo dos novos e grandes riscos. O que vale por questionar se o direito penal, tal como o conhecemos, cabe algum papel na defesa das gerações futuras, ou se terá de se tornar em um «direito penal do risco».

ROXIN $^{127}$ assinala que, ao combater os novos riscos através da intervenção do direito penal, há que preservar a subordinação dessa intervenção ao princípio da protecção do bem jurídico e aos demais princípios de imputação jurídico-penal próprios de um Estado de Direito. Onde tal desígnio não seja possível, o direito penal deve abster-se de intervir. É justamente aqui que as divergências doutrinais começam, dividindo-se a doutrina em três facções: uma, mais conservadora, nega a intervenção do direito penal nos domínios do risco. Outra, assumindo uma posição de ruptura paradigmática, propõe a completa funcionalização do direito penal aos valores da segurança colectiva e da paz social. Numa posição intermédia, está a doutrina que propõe um expansionismo controlado do direito penal através da sua estruturação em diferentes níveis de actuação.

A doutrina da Escola de Frankfurt, representada por autores como HASSEMER, HERZOG e PRITTWITZ, nega que o direito penal possa e deva ser o instrumento ao qual os Estados hão-de recorrer para mitigar os problemas do risco, pois antevê que a intervenção do direito penal nessa matéria fará com que este se adultere, funcionalizando-se e desformalizando-se paulatinamente por influência de políticas criminais securitárias, às quais os Estados serão inevitavelmente conduzidos, perante a ubiquidade e incontrolabilidade dos novos riscos e a necessidade de incutir a sensação de segurança na comunidade ${ }^{128}$. A funcionalização do direito penal manifestar-se-ia, essencialmente, pela sua expansão e administrativização em detrimento de princípios como o da protecção exclusiva de bens jurídicos, o princípio da subsidiariedade, o princípio da mínima intervenção, aproximando-se da ideia de um direito de mera ordenação social, marcado pela excessiva antecipação da tutela penal, através da eleição de bens jurídicos vagos, ou mesmo através da proliferação de crimes de perigo abstracto e crimes de perigo comum, e na enfatização da prevenção geral positiva ou inte-

127 Claus ROXIN, Derecho Penal. Parte General. Tomo I. Fundamentos. La estructura de la Teoría del Delito, Traducción de LUZÓN-PEÑA; García CONLLEDO; Vicente REMESAL, Civitas, Madrid, 1997, p. 61. Cfr. Hermínio RODRIGUES, op. cit. P. 24. Vide, tb., Francisco MUÑOZ CONDE. Protección de Bienes Jurídicos como Limite Constitucional al Derecho Penal, Quintero Olivares / Morales Prats (Coords.). El Nuevo Derecho Penal Español Estudios Penales en Memoria del Profesor José Manuel Valle Muñiz, Editorial Aranzadi, Madrid, 2001.

128 Cfr. Winfried HASSEMER, Perspectivas del Derecho Penal Futuro, Revista Penal, Universidad de Huelva, 1998, p. 37-41; Winfried HASSEMER, Crisis y características del moderno derecho penal. Actualidad Penal, n. ${ }^{\circ}$ 43/22, Madrid, 1993, p. 635-646. 
gradora como fim da pena ${ }^{129}$. A desformalização revelar-se-ia, quer no recurso a técnicas legislativas obscuras, caracterizadas pelo uso corrente de conceitos indeterminados, cláusulas gerais e normas penais total ou parcialmente em branco, quer na flexibilização das categorias dogmáticas tradicionais, como a culpa, objectivando a responsabilidade penal e proscrevendo o próprio princípio da legalidade ${ }^{130}$. Os penalistas da Escola de Frankfurt apenas admitem a intervenção do direito penal nos moldes de uma construção jurídico-penal de matriz estritamente liberal, caracterizada pela protecção de bens jurídicos individualizáveis (concepção monista-pessoal) e pela manutenção da função crítica ${ }^{131}$ do conceito de bem jurídico, sendo, que, nesses moldes, será totalmente ineficaz para a promoção da segurança das gerações futuras sem que se transforme num direito penal parcial. ${ }^{132}$ Pelo que, para assegurar a protecção perante os «mega-riscos» há que lançar mão de outros ramos do Direito e, sobretudo, de meios não jurídicos de controlo social ${ }^{133}$, mais orientados em termos preventivos, renunciando à reprovação pessoal e à imposição de penas privativas da liberdade ${ }^{134}$. A este sistema paralelo ao direito penal chamou HASSEMER de "direito de intervenção", o qual, na verdade, é algo muito próximo de uma tutela administrativa reforçada ${ }^{135}$.

Precisamente nos antípodas das teses da Escola de Frankfurt, encontram-se aqueles que defendem a mudança de perspectiva do direito penal para uma lógica inteiramente funcionalizada às exigências próprias da «sociedade do risco»: uma lógica de controlo social marcado pela atenuação grave de princípios básicos de raiz iluminista e liberal, pela recusa

129 Peter Alexis ALBRECHT, El Derecho Penal en la intervención de la política populista, in: La Insostenible Situación del Derecho Penal, Comares, Granada, 2000, pp. 474-475. Cfr. Hermínio RODRIGUES, op. cit., p. 25.

$130 \mathrm{Cfr}$. Wolfgang NAUCKE, La progressiva pérdida de contenido del princípio de legalidade penal como consecuencia de um positivismo relativista y politizado, in: La Insostenible Situación del Derecho Penal, Comares, Granada, 1993, pp. 531 e ss.

131 Winfried HASSEMER, Persona, mundo y responsabilidad. Bases para una teoria de la imputación en Derecho Penal, Tirant lo Blanch, Valencia, 1999, p. 40.

132 Cornelius PRITTWITZ, o Direito Penal entre o Direito Penal do Risco e o Direito Penal do Inimigo: Tendências Actuais em Direito Penal e Política Criminal, in: Revista Brasileira de Ciências Criminais, São Paulo, Revista dos Tribunais - n. ${ }^{\circ} 47$, IBCCRIM, Mar/Abr. 2004.

133 Cfr. Winfried HASSEMER, Persona, mundo y responsabilidad. Bases para una teoria de la imputación en Derecho Penal, Tirant lo Blanch, Valencia, 1999, pp. 67-73.; Felix HERZOG, Limites del Derecho Penal para controlar los riesgos sociales, in: Poder Judicial n. ${ }^{\circ}$ 32, 1993, pp. 80 e ss. Contra, Jorge de FIGUEIREDO DIAS, Direito Penal, Parte Geral - Tomo I..., cit., Coimbra Editora, Coimbra, 2004, p. 131 e ss. e Jorge de FIGUEIREDO DIAS, 0 direito penal entre a "sociedade industrial" e a "sociedade do risco", BFDUC, Stvdia Ivridica, n. ${ }^{\circ}$ 61, Coimbra, 2001, p. 596.; Claus ROXIN, Derecho Penal - Parte General..., cit., pp. 61-62; MARINUCCI / DOLCINNI, Diritto penale minimo e nuove forme de criminalitá, Rivista Italiana di Diritto e procedura penale, 1999, pp. 808 e ss. Cfr., também, Augusto SILVA DIAS, Op. cit., p. 28. Cfr. Hermínio RODRIGUES, op. cit., p. 28.

134 Cfr. Winfried HASSEMER; Francisco MUÑOZ CONDE, La Responsabilidad por el Producto en Derecho Penal, Tirant lo Blanch, Valencia, 1995, p. 46 e Winfried HASSEMER, Person, Welt und Werantwortlichkeit. Prolegomena einer Lehere von der Zurechnung im Strafrecht", apud Mário Ferreira MONTE, O Direito Penal tem futuro..., apontamento introdutório a Paulo S. FERNANDES, Globalização, Sociedade do Risco e o Futuro do Direito Penal, Almedina, Coimbra, 2001, p. 25. Cfr. Hermínio RODRIGUES, op. cit., p. 28.

135 Cfr. Jorge de FIGUEIREDO DIAS, Op. cit., pp. 131; Vide, tb., Jorge de FIGUEIREDO DIAS, O direito penal entre a "sociedade industrial" e a "sociedade do risco"..., cit., p. 596. 
total do reconhecimento da ordem axiológica que advém do axioma onto-antropológico do direito penal e pela eleição da gestão do risco, através da neutralização e inocuização de certos grupos, como fim último da ordem punitiva. ${ }^{136}$ É uma proposta baseada na aplicação do dogma da razão técnico-instrumental na prevenção dos novos (e dos velhos) riscos, levando-o ainda mais longe sob a forma de uma razão calculadora probabilística. ${ }^{137}$ No direito anglo-saxónico, fala-se mesmo de uma "actuarial justice"138, ou seja, no uso do cálculo de probabilidades na prevenção criminal, o que passa pela identificação de certos grupos de alto potencial criminógeno. As teorias criminológicas interaccionistas da sociologia criminal norte-americana ganham aqui expressão, já que a doutrina da justiça actuarial parte do pressuposto de que o crime é um factor social conatural que deve ser gerido por referência a índices, sendo a reacção do sistema orientada para a gestão de perfis de risco numa actuação profiláctica de pura prospecção, no sentido do evitamento e não da prevenção propriamente dita. Mais do que penas, este sistema propõe autênticas medidas de segurança baseadas numa perigosidade probabilística aferida por indicadores estatísticos ${ }^{139}$. Assim se lograria uma redução dos danos globais inerentes ao crime, através de uma adequada redistribuiç̧ão dos riscos, tanto no plano da prevenção como no plano da repressão ${ }^{140}$.

Concepção muito próxima é preconizada por JAKOBS. Apontando a incapacidade do direito penal tradicional e da dogmática penal finalista para responder de forma eficaz ao sentimento generalizado de insegurança no universo da globalização, JAKOBS preconiza o advento de uma nova lógica sancionatória de pendor fortemente funcionalista. Em total oposição com uma política criminal fundada na tutela de direitos fundamentais dos cidadãos, despreza o critério da protecção do bem jurídico e elege a tutela da validade da norma como propósito fundamental. ${ }^{141}$

Idealizando um sistema dualista, baseado nas teorias de KANT e de HOBBES, distinguindo entre «cidadão» e «inimigo», entre «pessoa» e «objecto», bem como nas concepções de ROUSSEAU e FICHTE sobre a quebra do contrato social e, ainda, da violação do con-

136 Cfr. Hermínio RODRIGUES, op. cit., p. 35 .

137 Idem, ibidem.

138 Cfr. André Lamas LEITE, Nova penologia, punitive turn e direito criminal: quo vadimus? pelos caminhos da incerteza (pós-)moderna, in: Direito Penal - Fundamentos Dogmáticos e Político-Criminais - Homenagem ao Prof. Peter Hünerfeld, Coimbra, Coimbra Editora, 2013, p. 395-476; Bernardo del ROSAL BLASCO, Hacia un Derecho Penal de la Postmodernidad?, in: Revista Electrónica de Ciencia Penal y Criminología, 2009, n. ${ }^{\circ}$ 11-08, p. 8-35; M. FREELEY / J. SIMON, Actuarial Justice: The Emerging New Criminal Law, in: Crime and the Risk Society, O'MALLEY (org.) 1998, p. 375. Vide, tb. Bernardo del ROSAL BLASCO, Hacia un Derecho Penal de la Postmodernidad?, in: Revista Electrónica de Ciencia Penaly Criminología, 2009, n. ${ }^{\circ}$ 11-08, p. 8-35 e Pedro CAEIRO, Legalidade e oportunidade: a perseguição penal entre o mito da "justiça absoluta" e o fetiche da "gestão eficiente" do sistema, RMP 84, 2000, p. 31 e ss.

139 Cfr. Hermínio RODRIGUES, op. cit., p. 37.

140 Pedro CAEIRO, Legalidade e oportunidade: a perseguição penal entre o mito da "justiça absoluta" e o fetiche da "gestão eficiente" do sistema, in: RMP 84, 2000, p. 44.

141 Cfr. Hermínio RODRIGUES, op. cit., pp. 29-33. 
senso de LEIBNIZ, JAKOBS propõe a aplicação de um direito penal nos moldes tradicionais para aqueles que são normalmente cumpridores (cidadãos) e um outro para aqueles que sejam habitual e reiteradamente delinquentes (inimigos). Para estes, aposta num sistema axiologicamente neutro onde o valor supremo é a integridade da norma, na melhor tradição de HEGEL. A esse sistema chamou: “direito penal do inimigo". Segundo JAKOBS ${ }^{142}$, o direito penal do inimigo caracteriza-se, essencialmente, por três elementos, sendo o primeiro deles a antecipação da tutela penal, ou seja, trata-se de um direito penal cujo referente essencial é o perigo (risco mesmo!) do cometimento do delito, a iminência real ou conjectural do crime, e não o facto criminoso, tratando-se, assim, de um direito penal que não se funda no facto cometido mas na probabilidade de (ou propensão para) o cometer. Assim, a natureza intrínseca do conceito de "direito penal do inimigo" está em ser uma reacção violenta do ordenamento jurídico contra indivíduos especialmente perigosos, aplicando medidas de segurança de modo a conter ao máximo o espaço de livre actuação desses indivíduos, apostando tudo na neutralização do «inimigo» da paz social. A finalidade do direito penal passa a ser a tutela da norma e do sistema. O bem jurídico poderá ser indirectamente protegido, mas já não terá qual função crítica, dogmática ou legitimadora ${ }^{143}$.

Numa posição intermédia entre a preservação do carácter puramente instrumental do direito penal e a sua completa funcionalização está a doutrina que defende um expansionismo moderado, a qual encontra melhor exemplo na teoria do direito penal «a duas velocidades» de SILVA-SANCHÉZ. Partindo, tal como HASSEMER, da convicção de que a configuração e as aspirações das novas sociedades exigem uma expansão do direito penal e que este não poderá, por muito mais tempo, conservar as mesmas exigências dogmáticas ${ }^{144}$, SILVA-SANCHÉZ procura responder ao problema através de uma política de expansão do

142 Cfr. Günther JAKOBS; Manuel CANCIO MELIÁ, Derecho penal del inimigo, Civitas, Madrid, 2003, p. 30 e ss. Cfr. tb., Günther JAKOBS, La Ciencia Penal ante los Retos del Futuro, in: Albin ESER / Winfried HASSEMER / Björn BURKHARDT, La ciencia del Derecho Penal ante el cambio de Milenio, Trad. de Teresa MANZO, Francisco MUÑOZ CONDE (Coord.), Valencia, 2004; F. MUÑOZ CONDE El nuevo Derecho penal autoritario, in: El Derecho ante la globalización y el terrorismo, AA. VV., Tirant lo Blanch, Valencia, 2004; F MUÑOZ CONDE, El nuevo Derecho penal autoritario: consideraciones sobre el llamado Derecho penal del enemigo, in: Mutaciones de Leviatán. Legitimación de los nuevos modelos penales, AA. VV., Akal, Madrid, 2005: Miguel POLAINO-ORTS, Derecho Penal del Enemigo. Fundamentos, Potencial de Sentido y Limites de Vigencia, Bosch, Barcelona, 2009; Luis GRACIA MARTIN, El horizonte del finalismo y el derecho penal del enemigo, Tirant Lo Blanch, Valencia, 2005; Luis GRACIA MARTIN, Consideraciones Críticas Sobre al Actualmente Denominado Derecho Penal del Enemigo, in: Revista Electrónica de Ciencia Penal y Criminología (RECPC) 07-02, 2005. Cfr. Hermínio RODRIGUES, op. cit., p. 32.

143 Günther JAKOBS, Sobre la Normativización de la Dogmática Jurídico-Penal, trad. CANCIO MELIÁ / FEIJÓO SANCHÉZ, Thomson-Civitas, Madrid, 2003, pp. 59-61. Cfr. Hermínio RODRIGUES, op. cit., p. 30.

144 Jesús María SILVA-SANCHÉZ (La Expansión del Derecho Penal..., cit., pp. 65 e ss.) diz: "La visión del Derecho penal como único instrumento eficaz de pedagogía político-social, como mecanismo de socialización, de civilización supone una expansión ad absurdum de la otrora ultima ratio." 
direito penal consubstanciada numa dogmática dualista, que resulta naquilo que chama de "direito penal de (ou a) duas velocidades"145.

Defendendo, como TIEDEMANN ${ }^{146}$, uma divisão do direito penal em sectores de intervenção, consoante os tipos de criminalidade, SILVA-SANCHÉZ propõe uma estruturação em dois níveis que correspondem a outras tantas lógicas de intervenção. Deve, segundo o autor, manter-se a existência de um cerne de direito penal, relativamente ao qual valham, imodificados, os princípios do direito penal clássico, dirigido à protecção subsidiária e fragmentária de bens jurídicos individuais. Mas, considera o autor, deve existir também uma periferia jurídico-penal, especificamente dirigida à protecção contra os "grandes e novos riscos", onde aqueles princípios se encontrem esbatidos ou mesmo transformados. Para tanto, propõe um modelo de "flexibilização controlada"147 das regras de imputação (responsabilidade das pessoas colectivas, ampliação dos critérios da autoria e da comissão por omissão, etc.) e dos princípios de garantia do direito penal clássico como forma de responder à necessidade de protecção das sociedades actuais.

Onde a proposta de SILVA-SÁNCHEZ é inovadora face ao direito de intervenção de HASSEMER é no facto de que a «flexibilização controlada» que propõe ter lugar dentro do direito penal e não numa lógica de administrativização do combate aos novos riscos. Ou seja, SILVA-SANCHÉZ não nega aptidão do direito penal para resolver os problemas da sociedade pós-moderna, pós-industrial e globalizada. Simplesmente considera que não o poderá fazer mantendo o seu carácter garantista nos moldes tradicionais, havendo de se expandir a novas formas de actuação, mais adaptadas ao contexto da sociedade do risco. Contudo, não quer isto dizer que o direito penal haja de perder de vista a sua função protectora de bens jurídicos, designadamente os bens jurídicos supra-individuais.

Da análise destas três grandes tendências resulta patente que a eventual mudança de paradigma na concepção de um direito penal para a «sociedade do risco» depende, em muito, da viabilidade da manutenção do bem jurídico-penal como referente fundamental da política criminal, ou seja, a sua preservação como topos do direito penal pós-moderno. $\mathrm{O}$ direito penal do futuro visará a protecção exclusiva e subsidiária de bens jurídicos contra a sua lesão ou perigo de lesão ou o puro controlo de risco?

Para quem preconize uma concepção puramente monista-pessoal dos bens jurídicos penais, como os autores da escola de Frankfurt, não cabe ao direito penal qualquer papel na

145 Jesús Maria SILVA-SANCHÉZ, La Expansión del Derecho Penal..., cit., pp. 121 e ss. Cfr. Hermínio RODRIGUES, op. cit.. p. 38.

146 Cfr. Augusto SILVA DIAS, Protecção Jurídico-Penal do Interesses dos Consumidores, $3 .^{\text {a }}$ ed. policop., FDUC - IDPEE, Coimbra, 2001, p. 36.

147 Jesús Maria SILVA-SÁNCHEZ, Op. cit., p. 125, nota 85. Cfr. Hermínio RODRIGUES, op. cit., p. 38. 
resposta aos problemas macro-sociais da sociedade futura, pelo que não está em causa, de modo algum, o abandono do seu carácter instrumental. As respostas adequadas residem em sistemas não-penais de controlo, sendo que a linha de fronteira para a intervenção do direito penal consiste, precisamente, no bem jurídico individual ${ }^{148}$.

Partidários do expansionismo controlado, como SILVA DIAS e SILVA-SÁNCHEZ, defendem, numa concepção dualista do objecto do direito penal, que o direito penal só logrará um papel adequado na contenção dos mega-riscos na medida em que se adapte à protecção, a par de bens jurídicos individuais, de bens jurídicos supra-individuais ou intermédios, desde que estes tenham um referente pessoal ${ }^{149}$, isto é, que protejam um interesse ou valor individualmente fruível, o que sucede desde que o respectivo dano afecte pessoas ou interesses pessoais.

Já autores como ROXIN e SCHÜNEMANN ${ }^{150}$, concebem estes bens jurídicos supra-individuais como sendo instrumentos para a protecção de interesses individualmente fruíveis. Para esta teoria, há bens jurídicos que, atento o seu carácter essencial para a preservação das condições necessárias à sobrevivência da própria humanidade, assumiriam relevância penal instrumental, sendo a sua protecção uma técnica de antecipação da tutela dos "valores-fins" essenciais, protegidos pelos bens jurídicos individuais. ${ }^{151}$ Para esta teoria,

148 Cfr. Winfried HASSEMER, Persona, mundo y responsabilidad. Bases para una teoría de la imputación en Derecho Penal, trad. de F. Muñoz Conde y M.M. Díaz Pita, Tirant lo Blanch, Valencia, 1999, pp. 30-38; Winfried HASSEMER, Perspectivas del Derecho Penal del Futuro, RP, n. ${ }^{\circ}$ (1997), pp. 37 e ss.; winfried HASSEMER, Contra el abolicionismo: acerca del porqué no se deberia suprimir el derecho penal, RP, n..$^{\circ} 11$ (2003), pp. 31 e ss.; Winfried HASSEMER, Lineamentos de una teoría personal del bien jurídico, DP, Año 12(1989), p. 275 e ss.; Na mesma linha seguem Luigi FERRAJOLI, Diritto e Ragione. Teoria del Garantismo Penale, Laterza, Roma, 1990, p. 479-481; LÜDERSSEN, apud Cornelius PRITTWITZ, El Derecho Penal Alemán: ¿fragmentario? ¿subsidiario? ¿ultima ratio? Reflexiones sobre la razón y limites de los principios limitadores del Derecho penal", in: La insostenible situación del Derecho penal, AA. VV., trad. Maria Teresa Castiñeira Palou, Granada, Comares, 2000, p. 433.

149 Cfr. Augusto SILVA DIAS, Op. cit., p. 29; Augusto SILVA DIAS, Entre «comes e bebes»: debate de algumas questões polémicas no âmbito da protecção jurídico-penal do consumidor, IDPEE, vol. III, Coimbra Editora, Coimbra, 2009, p. 485; Jesús Maria SILVA-SÁNCHEZ, La Expansión del Derecho Penal. Aspectos de la Política Criminal en las Sociedades Postindustriales, Civitas, Madrid, 1999, p. 98. No mesmo sentido, vide Ricardo M. MATA Y MARTÍN, Bienes jurídicos intermedios y delitos de peligro: aproximación a los presupuestos de la técnica de peligro para los delitos que protegen bienes jurídicos intermedios, Granada : Comares, 1997, p. 23 e ss.; José de FARIA COSTA, Direito Penal Económico, Quarteto, Coimbra, 2003, p. 35 e ss.; Mirentxu CORCOY BISADOLO (Delictos de Peligro y Protección de Bienes Jurídico-penales Supraindividuales, Valencia, Tirant lo Blanch, 1999, pp. 139 e ss.; Sergio MOCCIA, De la tutela de bienes a la tutela de funciones: entre ilusiones postmodernas y reflujos iliberales, in: Politica Criminal y Nuevo Derecho Penal (libro homenaje a Claus Roxin), Bosch, Barcelona, 1997, pp. 118-119 e ss.

150 Claus ROXIN, Derecho Penal, trad. Luzón Peña, Garcia Conledo, Vicente Remesal, Civitas, Madrid, reimp. 200o, pp. 410-411. Entre nós, vide Augusto SILVA DIAS, Delicta in se e delicta mere prohibita: uma análise das descontinuidades do ilícito penal moderno à luz da reconstrução de uma distinção clássica, FDUL Lisboa, 2003, pp. 820 e ss.

151 Cfr. Fernando MANTOVANI, Diritto Penale, Pádova, CEDAM, 2001, p. 208. Vide, tb. Fernando MANTOVANI, Princípio di ofensivitá tra dogmatica e politica criminale, in: Il Diritto Penale alla Svolta di Fine Millenio, G. Giappichelli Editore, Torino, 1998, p. 248 e ss.; Carlos MÁRTINEZ-BUJAN PEREZ, Derecho Penal Económico - Parte General, Tirant lo Blanch, Valencia, 1998, pp. 93-96. Em sentido contrário, vide Augusto SILVA DIAS, Delicta in se..., cit., p. 690, para quem os bens jurídicos supra-individuais não se encontram em tal relação de subornação e de instrumentalidade. 
portanto, um direito penal para a «sociedade do risco» deveria assumir, como sua função primordial, o asseguramento das condições essenciais, de uma perspectiva macro-social, para que os bens jurídicos individuais possam ser fruídos. Essa função seria prosseguida, justamente, pela redução do grau de risco de lesão destes bens jurídicos individuais, o que passaria por uma intensificação da tutela preventiva em relação à lesão dos bens jurídicos instrumentais. ${ }^{152}$

Uma parte da doutrina vai ainda mais longe e avança o conceito de bem jurídico colectivo na própria acepção do termo. É o que defendem autores como FIGUEIREDO DIAS ${ }^{153}$, TIEDMANN ${ }^{154}$, HEFENDEHL ${ }^{155}$. A necessidade de reconhecer os bens jurídicos colectivos como valores e interesses dignos de protecção penal, ao lado dos bens jurídicos estritamente individuais, decorre, inexoravelmente, dos problemas com que o direito penal se depara na protecção dos pilares axiológicos que sustentam as sociedades pós-modernas. Para FIGUEIREDO DIAS, a especificidade do bem jurídico colectivo reside no facto de poder ser gozado por todos e por cada um, sem que ninguém deva ficar excluído; nessa possibilidade de gozo reside o legítimo interesse individual na integridade do bem jurídico colectivo ${ }^{156}$. O autor rejeita, pois, uma concepção de bem jurídico demasiado antropocêntrica "que de bem jurídico só permite falar quando estejam em causa interesses reais, tangíveis e, por consequência, também actuais do indivíduo"157, ou mesmo uma concepção moderada de bem jurídico colectivo que só lhe atribua relevância penal na medida em que o mesmo possa ser ligado a um interesse individual.

Reconhece-se, então, ao lado dos bens jurídicos individuais, a existência de verdadeiros bens jurídicos colectivos, bens jurídicos de carácter social, trans-individuais, sendo na respectiva tutela que reside o verdadeiro papel fundamental do direito penal do futuro.

STRATENWERTH, por outro lado, propõe a completa superação do conceito de bem jurídico e a sua substituição pela tutela directa de relações da vida como tais. Face aos novos desafios que se colocam ao direito penal pós-moderno, este autor prevê a falência do bem jurídico como referente fundacional da dignidade penal da conduta e justificação primeira

152 Cfr. Hermínio RODRIGUES, op. cit., p. 53.

153 Cfr. Jorge de FIGUEIREDO DIAS, O Papel do Direito Penal..., cit., p. 1129.

154 Cfr. Klaus TIEDEMANN, Lecciones de Derecho Penal Económico, PPU, Barcelona, 1993, p. 35. Vide, tb. LÓPEZ CALERA, Hay derechos colectivos? Individualidad y socialidade en la teoria de los derechos colectivos, Barcelona, Ariel, 2000.

155 Cfr. Roland HEFENDEHL, Debe Ocuparse El Derecho Penal de Riesgos Futuros? Bienes Jurídicos Colectivos y Delictos de Peligro Abstracto, in: Anales de Derecho, n. ${ }^{\circ}$ 19, Universidad de Murcia, 2001, p. 156.

156 Cfr. Susana AIRES DE SOUSA, Os Crimes Fiscais..., cit., p. 219. Cfr. Hermínio RODRIGUES, op. cit., p. 49.

157 Cfr. Jorge de FIGUEIREDO DIAS, O Papel do Direito Penal..., cit., p. 113o. Também Mário FERREIRA MONTE partilha desta visão. Cfr. Mário FERREIRA MONTE Da Protecção Penal do Consumidor. O problema da (des)criminalização do incitamento ao consumo, Coimbra, Almedina, 1996, pp. 206-207. Vide, ainda, J. J. Gomes CANOTILHO, Tomemos a Sério os Direitos Económicos, Sociais e Culturais, BFD, Coimbra, Coimbra Editora, 1988, p. 40. 
da intervenção penal ${ }^{158}$. Partindo da ideia de que, perante a complexidade e constante modificação das condutas lesivas dos interesses colectivos e uma cada vez maior indeterminabilidade do conceito de bem jurídico individual, pela erosão do seu referente pessoal, uma protecção penal de interesses colectivos eficaz exige que o ilícito material respectivo tenha de ser ancorado em condutas socialmente irrelevantes ou insignificativas na sua singularidade, só se tornando socialmente danosas em associação com condutas análogas ocorridas em massa ${ }^{159}$. Assim, em substituição do desvalor do resultado aferido no dano ou no perigo de lesão do bem jurídico, STRATENWERTH avança o conceito de ultrapassagem do valor-limite como critério de intervenção penal. Trata-se de opor exigências de valor intensificadas aos que participam de actividades geradoras de grandes riscos, «grandes normas de comportamento» ${ }^{160}$. O cumprimento destes deveres permitiria a diminuição dos limites do risco permitido e na formulação de novas posições de garante, nomeadamente quanto ao controlo de fontes de perigo. Progride-se, assim, para uma paulatina substituição do desvalor do resultado pelo desvalor da acção como critério de ilicitude penal. ${ }^{161}$

"A «sociedade do risco» é a manifestação contemporânea de um fenómeno recorrente, a saber, a procura de uma fundamentação para introduzir na dogmática critérios que venham modificar o princípio da responsabilidade pessoal. ${ }^{162}$ No que diz respeito à fundamentação político criminal e ao objecto da responsabilidade penal, estamos em crer que essa modificação não deverá, pois, acontecer no direito penal do futuro, devendo este manter-se fiel à sua matriz liberal. Um direito penal subsidiário, mínimo e fragmentário, materialmente e teleologicamente legitimado pela preservação axiológica social e orientado para a prevenção.

Direito penal do futuro: um direito de liberdade?

Vimos como o advento do racionalismo humanista trouxe o valor da segurança jurídica do indivíduo face à actuação do Estado, reacção necessária à concepção hobbesiana do poder despótico e absoluto como garante último da paz social. O Estado-de-Direito formal, baseado na legalidade (reserva de lei, tipicidade e irretroactividade) permitiu o afastamento

158 Cfr. Susana AIRES DE SOUSA, Os Crimes Fiscais..., cit., p. 223.

159 Cfr. Hermínio RODRIGUES, op. cit., pp. 50-51.

160 Cfr. Augusto SILVA DIAS, Entre «comes e bebes»: debate de algumas questões polémicas no âmbito da protecção jurídico- penal do consumidor (a propósito do acórdão da Relação de Coimbra de 10 de Julho de 1996), in: RPCC, ano VIII, 1998, n. ${ }^{\circ} 4$ e RPCC, ano 9, 1999, p. 75; Augusto SILVA DIAS, Os crimes de fraude fiscal e de abuso de confiança fiscal: alguns aspectos dogmáticos e político-criminais, in: Ciência e Técnica Fiscal, n. ${ }^{\circ}$ 394, 1999, p. 47.

161 Cfr. Klaus GÜNTHER, De la vulneración de un derecho a la infracción de un deber: un cambio de paradigma en el Derecho Penal?, in: La Insostenible Situación del Derecho Penal, Comares, Granada, 2000, p. 497.

162 Cfr. Maria Margarida SILVA PEREIRA, Direito Penal - Direito do Risco, Comparticipação Crimininosa, Tráfico de Influência, Quid Iuris, Lisboa, 2012 pp. 25-26. 
da legitimação totalitária do Estado. O primado da lei atribuiu garantias ao indivíduo face ao exercício do ius puniendi, garantias reforçadas por uma consagração constitucional formal, mas também material, corolário que são do princípio da dignidade da pessoa humana. Vimos, também, que, na $2 .^{\text {a }}$ metade do séc. XXI se aprofundou o humanismo penal, muito influenciado pelo pensamento de FERRAJOLI, tendo a idiossincrasia do "direito penal do cidadão" influenciado o legislador do último quartel do séc. XX.

Todavia, hoje, mais do que nunca, pede-se eficácia ao sistema de justiça penal e erige-se o valor da segurança colectiva a principal incumbência do Estado. Desencadeia-se, assim, um processo de negação e transformação paulatina dos princípios enformadores do Estado de Direito e pede-se ao direito penal que seja, simultaneamente, um «Direito de liberdade», limitador da intervenção estatal sobre a pessoa, e um «Direito de segurança», isto é, um direito compressor dos direitos da pessoa. Pede-se, pois, ao Estado que cumpra duas funções, colocando-o numa situação paradoxal: por um lado, que limite os seus poderes, em nome da protecção dos direitos fundamentais; por outro, que amplie os seus poderes também em favor dos direitos das pessoas.

A eficácia e eficiência do sistema (e a segurança colectiva), por um lado, e a protecção de direitos fundamentais do arguido, por outro, protagonizam uma intensa tensão dialéctica dentro do direito penal ${ }^{163}$, porque tensa é, também, a relação entre os valores da liberdade individual e da segurança. Actualmente, tendência dos Estados e das instâncias supra-estaduais para o reforçar do valor da segurança leva a reequacionar o equilíbrio de forças neste binómio.

A segurança tem o mesmo valor que a liberdade? A dignidade da pessoa humana também fundamentar e legitimar um outro plano da liberdade pessoal, no sentido do livre desenvolvimento da personalidade e realização da pessoa: o direito a fazer uso e fruição das suas liberdades fundamentais em segurança. Este direito à segurança tem acolhimento no acervo normativo supranacional, europeu e internacional, tanto no âmbito do sistema da Organização das Nações Unidas, como no sistema da União Europeia. Como pedra de toque nesta matéria, temos desde logo a Declaração Universal dos Direitos do Homem de 1948, instrumento de soft law, mas que se tornou na principal referência na construção da teoria dos direitos humanos, e consequentemente, dos direitos fundamentais da pessoa. $\mathrm{O}$ art. $3 .^{\circ}$ da DUDH estabelece que "todo o indivíduo tem direito à vida, à liberdade e à segurança pessoal". O art. 9..$^{\circ}$ do Pacto Internacional dos Direitos Civis e Políticos (PIDCP) reza que "Todo o indivíduo tem direito à liberdade e à segurança da sua pessoa.... Também

163 Já, há muitos anos, dizia João BAPTISTA MACHADO (Introdução ao Direito e ao Discurso Legitimador, Almedina, Coimbra, 1995, p. 58): "A exigência de segurança pode, porém, conflituar com a exigência de justiça. Justiça e segurança acham-se numa relação de tensão dialéctica." 
o art. $5 .^{\circ} \mathrm{n} \cdot{ }^{\circ} 1$ da Convenção Europeia sobre os Direitos Humanos (CEDH) diz que "toda a pessoa tem direito à liberdade e à segurança”. Já o reconhecimento formal de um catálogo de direitos humanos (de entre eles, o direito à segurança) no âmbito do sistema normativo da União Europeia só aconteceu com a Carta de Direitos Fundamentais da União Europeia de 2001, tendo adquirido força vinculativa em 2007, com o Tratado de Lisboa. O respectivo art. 6. ${ }^{\circ}$ estipula: "Toda a pessoa tem direito à liberdade e à segurança."

No plano constitucional interno, o direito à segurança aparece intimamente associado àqueloutro direito fundamental, a liberdade ${ }^{164} . \mathrm{O}$ art. $27 .^{\circ}$ da CRP estabelece que "todos têm direito à liberdade e à segurança”.

Mas, qual a relação de forças? Qual o interesse preponderante? Autores como ISENSEE contrapõem ao valor da segurança colectiva a ideia da liberdade individual como estatuto positivo indissociável à dignidade da pessoa, o que significa que o direito individual à segurança, elevando-se à categoria de direito fundamental, é, afinal, a própria condição de exercício pleno da liberdade. ${ }^{165}$ Esta concepção parte da ideia de que os direitos fundamentais não podem prescindir de um estatuto positivo que completaria o seu sentido e alcance, acrescendo ao estatuto negativo. Significa, então, que o programa constitucional contém uma vinculação do Estado à promoção das condições para o exercício do direito fundamental à liberdade, que forçosamente contraria, ou, pelo menos, serve de contrapeso, à tendência para a funcionalização do sistema penal ao valor da segurança colectiva. Acresce que o sistema de normas sobre direitos fundamentais deve ser interpretado como não sendo passível de interpretação restritiva, o que favorece a ideia de que aqueles direitos hão-de prevalecer sobre programas penais securitários votados à integridade do sistema. ${ }^{166}$

Por outro lado, Franz KAUFMANN e Niklas LUHMANN apontam ${ }^{167}$ a incapacidade que a intervenção securitária penal tem de controlar os «novos riscos», pois que estes teriam uma capacidade adaptativa crescente, tornando inútil a restrição das liberdades individuais em prol da percepção de segurança colectiva.

Estas ideias apontam para uma clara preponderância da liberdade sobre o interesse da segurança cognitiva. Como nos diz GUEDES VALENTE: "a prossecução da segurança interna e a perseguição criminal não podem ser motivo ou fundamento para um restrição

164 Cfr. Gomes CANOTILHO / Vital MOREIRA, Constituição da República Portuguesa Anotada, vol. I, 4. ${ }^{a}$ ed., Coimbra Editora, Coimbra, 2007, pp. 478 e 479.

165 Cfr. Maria Margarida SILVA PEREIRA, Direito do Risco..., cit., p. 21.

166 Vide Jorge MIRANDA, Manual de Direito Constitucional, Tomo IV, 3. ${ }^{\text {a }}$ ed., Coimbra Editora, Coimbra, 200o, pp. 337-341; GOMES CANOTILHO e VITAL MOREIRA, Constituição da República Portuguesa Anotada, Vol. I, 4. ${ }^{\text {a }}$ ed., Coimbra Editora, Coimbra, 2007, pp. 388-396; José Carlos VIEIRA DE ANDRADE, Os Direitos Fundamentais na Constituição Portuguesa de 1976, 3. ${ }^{\mathrm{a}}$ ed., Almedina, Coimbra, 2004, pp. 298-312.

167 Cfr. Maria Margarida SILVA PEREIRA, Op. cit., p. 24. 
desadequada, desnecessária, inexigível, desproporcional stricto sensu, ou para o aniquilamento do conteúdo, do alcance e extensão dos direitos fundamentais, porque estes são, simultaneamente, o seu legado legítimo e o seu limite." ${ }^{168}$ Acresce que quaisquer normas destinadas à prevenção e repressão de delitos susceptíveis de contender com direitos fundamentais devem, não só, observar princípios constitucionais e penais, como também gozar, para além da legitimidade normativa, de legitimidade sociológica apoiada na defesa dos valores defendidos pela comunidade. ${ }^{169}$

Não obstante, a tendência para a eleição da segurança colectiva como valor reitor da política criminal tem-se demonstrado mesmo ao nível das Instituições da União Europeia ${ }^{170}$, onde se tem instalado um discurso «belicista», marcado por palavras de ordem como "luta", "combate", "tolerância zero". ${ }^{171}$ Sobre isto, Augusto SILVA DIAS diz-nos, de forma peremptória, que a União Europeia concebe o sistema penal como "um instrumento de política de segurança, sem que a liberdade cidadã seja tida como um contrapeso ou travão à sua expansão." ${ }^{172}$ No âmbito do projecto europeu de construção do terceiro pilar - um grande espaço de «liberdade, segurança e justiça», muito embora uma harmonização dos ordenamentos jurídico-penais pudesse demonstrar a preocupação com uma aplicação mais igualitária das garantias penais, a verdade é que o grande referente daquele espaço é, nos termos do TFUE (art. 67. ${ }^{\circ}$ ), o valor da segurança, o qual norteia toda a função de protecção das liberdades e direitos fundamentais no espaço europeu. ${ }^{173} \mathrm{Ou}$ seja, a edificação do espaço penal europeu far-se-á sob a égide da segurança como garante da liberdade, no sentido de realizar a justiça, segurança essa operacionalizada por via cooperação penal, em detrimento da harmonização. ${ }^{174}$ Fica, assim, muito debilitada a construção da própria ideia de «cidadania europeia», ao mesmo tempo que se adopta uma atitude belicista de exclusão e coisificação em relação àqueles que perturbarem. Diz-nos Pedro CAEIRO: “(...) até agora, o espaço de liberdade, segurança e justiça tem funcionado, principalmente, no sentido de uma compressão da liberdade, em homenagem à segurança (ou, o que é o mesmo, no sentido da liberdade atra-

168 Manuel M. GUEDES VALENTE, Contributos para um Direito Penal Supranacional, $3 .^{\text {a }}$ ed., Legit, s/l, 2018, p. 17.

169 Cfr. Manuel M. GUEDES VALENTE, Op. cit., p. 16.

170 Cfr. Pedro CAEIRO, Cooperação Judiciária na União Europeia, in: Direito Penal Económico e Europeu: Textos Doutrinários, Vol. III, Coimbra: Coimbra Editora, 2009, p. 77; Anabela MIRANDA RODRIGUES, O Mandado de Detenção Europeu - Na Via da Construção de um sistema penal europeu: um passo ou um salto?, in: O Direito Penal Europeu Emergente, Coimbra Editora, Coimbra, 2008, p. 219; Idem, A Emergência de um "Direito Penal Europeu" - Questões Urgentes de Politica Criminal, in: O Direito Penal Europeu Emergente, Coimbra Editora, Coimbra, 2008, pp. 236-237.

171 Pedro CAEIRO, Cooperação Judiciária na União Europeia..., cit., p. 76; José de FARIA COSTA, A Criminalidade em um Mundo Globalizado..., cit., p. 118.

172 Cfr. Anabela MIRANDA RODRIGUES, O Mandado de Detenção Europeu..., cit., pp. 191 e ss.; Augusto SILVA DIAS, De que Direito Penal Precisamos Nós Europeus? Um olhar sobre algumas propostas recentes de constituição de um direito penal comunitário, in: RPCC, Coimbra Editora, Coimbra, 2004, ano 14, n. ${ }^{\circ}$ 3, p. 318.

173 Cfr. Anabela MIRANDA RODRIGUES, A Emergência de um "Direito Penal Europeu..., cit. p. 228.

174 Cfr. Anabela MIRANDA RODRIGUES, Política Criminal - Novos Desafios, Velhos Rumos..., cit. p. 173. 
vés do direito penal) e não no sentido inverso (da liberdade contra o direito penal) (...)."175 Particularmente preocupante, nesta matéria, é o facto de a prioridade dada à estratégia do reconhecimento mútuo em detrimento da harmonização legislativa, pode conduzir o legislador das Estados-Membros a pautar os seus respectivos ordenamentos por um nível mínimo essencial de garantias substantiva e processuais, de modo a flexibilizar e agilizar os mecanismos de cooperação policial e judiciária. ${ }^{176}$

Esta edificação de um mega-sistema punitivo de índole securitária demonstra a tendência actual para um claro retorno à noção do "delinquente-inimigo"177, fortemente influenciada pelas concepções criminológicas de GARÓFALO e da Escola Positiva Italiana: o criminoso irrecuperável por tendências inatas e fortemente perturbador da integridade de um espaço comunitário que se quer seguro, o qual há que inocuizar, adoptando-se, para tanto, a via da prevenção por antecipação da tutela penal, inclusive por recurso a indicadores resultantes de um cálculo actuarial, à guisa da política criminal norte-americana. $\mathrm{O}$ resultado final de uma tal política criminal mais não será do que a produção de outsiders, por diabolização daqueles que cometem factos típicos e ilícitos ${ }^{178}$, o que reforçará sempre, mais e mais, a justificação politico-criminal para a implementação de uma qualquer New Penology de inspiração actuarial e securitária, tal como proposto por FREELEY e SIMON. ${ }^{179}$

Um dos grandes desafios que hoje se colocam à legitimação da intervenção penal é, justamente, a identificação precisa dos limites que a Constituição impõe ao uso dos mais variados instrumentos de combate ao crime. O que há-de ser permitido, então, com forma de assegurar condições de efectiva liberdade? A supressão completa da própria liberdade? $\mathrm{O}$ valor da segurança autoriza a sua promoção a qualquer custo, mesmo com claro abuso de mandato social por parte do legislador e das forças de segurança numa espécie de estado-de-excepção, à guisa de SCHMITT ${ }^{180} \mathrm{O}$ direito penal há-de assentar numa concordância

175 Pedro CAEIRO, Op. cit., p. 77.

176 Cfr. Anabela MIRANDA RODRIGUES, O Mandado de Detenção Europeu..., cit., p. 217-218.

177 Manuel M. GUEDES VALENTE, Direito Penal do Inimigo..., cit., p. 105.

178 Cfr. José de FARIA COSTA, O Fenómeno da Globalização e o Direito Penal Económico, in: Direito Penal Económico e Europeu: Textos Doutrinários, Vol. III, Coimbra: Coimbra Editora, 2009, p. 121; Vide, sobre a teoria dos outsiders, Howard S. BECKER, Outsiders - Estudos de Sociologia Criminal, Zahar, Rio de Janeiro, 2008.

179 Cfr. FREELEY, M./SIMON, J. The New Penology: Notes on the Emerging Strategy of Corrections and its Implications, 30, Criminology 449, 470 (1992). Vide, ainda, André LAMAS LEITE, Nova penologia, punitive turn e direito criminal: quo vadimus? pelos caminhos da incerteza (pós-)moderna, in: Direito Penal - Fundamentos Dogmáticos e Político-Criminais Homenagem ao Prof. Peter Hünerfeld, Coimbra Editora, Coimbra, 2013, p. 395-476; Bernardo del ROSAL BLASCO, Hacia un Derecho Penal de la Postmodernidad?, in: Revista Electrónica de Ciencia Penal y Criminología, 2009, n. ${ }^{\circ} 11-08$, p. 8-35; KEMPF-LEONARD / PETERSON, Expanding Realms of the New Penology - The Advent of Actuarial Justice for Juveniles, in: Punishment \& Society, vol. 2, n. ${ }^{\circ}$ 1, January 2000, p. 66-97.

180 Vide Carl SCHMITT, Teologia Política, Trotta, Madrid, 2009; Giorgio AGAMBEN, Homo Sacer: O poder soberano e a vida nua, I, UFMG, Belo Horizonte, 2010; Jacques DERRIDA, Força de Lei: O fundamento Mítico da Autoridade, Martins Fontes, São Paulo, 2010. 
prática entre os imperativos político-criminais e o valor da liberdade individual, de modo a que uma correcta ponderação desses interesses possa conduzir a uma intervenção penal em defesa do quadro axiológico constitucional possa, ao mesmo tempo, respeitar o catálogo de direitos fundamentais e, assim, perspectivar a pessoa do agente como pessoa humana. ${ }^{181}$

Os direitos fundamentais são posições jurídicas activas das pessoas integradas no Estado-sociedade, exercidas por contraposição ao Estado-poder, previstas e garantidas pela Constituição, através de uma tutela reforçada. O objectivo próprio dos direitos fundamentais coincide, porque por ele é inspirado, com as finalidades macrossociais dos direitos humanos: exigir das instituições dotadas de prerrogativas de poder público, interno ou internacional, actuação e tratamento condignos com a condição da Humanidade, o que implica que, nomeadamente, o poder do Estado, se abstenha de intromissões desnecessárias e desproporcionais na esfera do indivíduo, devendo perspectivá-lo, na sua essência imutável, como um fim em si mesmo e nunca como um meio de realização de interesses supra-individuais da colectividade. ${ }^{182}$ Isto significa que, no plano constitucional, os direitos fundamentais buscam a sua legitimidade directamente na dignidade da pessoa humana, o que determina que o poder do Estado só pode encarar a pessoa numa perspectiva personalista: nem individualista, como no liberalismo, nem transpersonalista, como nos regimes totalitários. ${ }^{183} \mathrm{~A}$ invalidade e a ilegitimidade das normas infraconstitucionais que não respeitem os direitos fundamentais, positivados ou não, deriva, justamente, do princípio da dignidade da pessoa humana assim interpretado.

Certo é, então, que a preocupação com a máxima eficácia do sistema penal não pode sobrepor-se à dignidade da pessoa humana, materializada nas garantias fundamentais do arguido, como têm defendido vários sectores da doutrina. ${ }^{184} \mathrm{~A}$ "explosão do direito penal omnipresente e omnipotente"185 pode incutir a ideia de uma maior organização social, mas não será capaz de inverter, no futuro, a descrença na eficácia da lei e do aparelho de Estado no controlo da criminalidade e a desconfiança generalizada nas instituições públicas. Isto porque uma concepção do direito penal como "bastão do Estado" capaz de destruir a cri-

181 Cfr. Manuel M. GUEDES VALENTE, Direito Penal do Inimigo..., cit., p. 125. Vide, tb. Manuel M. GUEDES VALENTE, Contributos para um Direito Penal Supranacional..., cit., pp. 30-31; Anabela MIRANDA RODRIGUES, Política Criminal..., cit., pp. 179-181;

182 Cfr. Jorge BACELAR GOUVEIA, Dignidade e Pessoa Humana, in: AAVV. Enciclopédia de Direito e Segurança (Bacelar GOUVEIA/Sofia SANTOS, coord.), Almedina, Coimbra, 2015, p. 112 e ss.

183 Cfr. Jesus González PÉREZ, La Dignidad de la Persona, Civitas, Madrid, 1986, pp. 23 e ss.

184 Cfr. Pedro CAEIRO, Cooperação Judiciária na União Europeia, in: Direito Penal Económico e Europeu: Textos Doutrinários, Vol. III, Coimbra: Coimbra Editora, 2009, pp. 76 e ss; José de FARIA COSTA, O Fenómeno da Globalização e o Direito Penal Económico..., cit., p. 111.

185 Gonçalo N. C. de Melo BANDEIRA, Responsabilidade Penal Económica e Fiscal de Entes Colectivos, Almedina, Coimbra, 2004, p. 36 
minalidade através da repressão violenta e da antecipação da tutela com base na pretensa periculosidade só provocará mais violência. ${ }^{186}$

Uma tal concepção, legitima a intervenção penal do Estado com finalidade de protecção da integridade de si próprio, como se fora um fim em si mesmo, operando-se, assim a completa inversão da própria noção de Estado democrático comprometido com a protecção dos valores do humanismo e fundado, sobretudo, na dignidade da pessoa humana. ${ }^{187}$ Ora, pelo contrário, o fim último do Estado e do seu mandato jus-político é, justamente, a promoção da dignidade da pessoa, o que só é possível através do reconhecimento de que a liberdade é o valor mais alto que preside à realização da justiça. $O$ valor segurança acrescido à justiça são condições do asseguramento da plena liberdade. ${ }^{188}$

Um Estado de Direito Democrático edificado à imagem do Homem, há-de resignar-se à inevitabilidade da insegurança, como condição da sua própria sobrevivência. ${ }^{189} \mathrm{~A}$ antítese entre demanda por segurança e respeito da dignidade da pessoa humana só pode ser resolvida pela (re)afirmação dos direitos fundamentais na definição de uma qualquer política criminal, a qual deve tetralogicamente fundada, como defende FERRAJOLI. ${ }^{190}$

O direito penal do futuro há-de, pois, concretizar o equilíbrio entre a função de protecção da sociedade e dos seus bens jurídicos essenciais e o integral respeito pela pessoa do delinquente face ao aparelho punitivo do Estado, de modo a que a pessoa do infractor seja perspectivada como um fim em si mesmo e nunca como um meio para atingir um certo estádio social ou uma desejada pacificação comunitária, através do uso do direito penal, material e processual como instrumento de segurança. ${ }^{191}$

"A «nova» justiça penal deve assumir o «rosto» da Humanidade"192. Logo, "o Direito penal não é nem deve ser um Direito de necessidade, mas um Direito de liberdade."193

\section{CONCLUSÃO}

A percepção dos riscos da globalização e da real ameaça da criminalidade organizada e transnacional (e, em alguns casos, global), bem como pânico gerado pelo fenómeno do

186 Cfr. Idem, ibidem.

187 Cfr. Albin ESER, Una justicia penal «A la medida del ser humano» en la época de la europeización y la globalización, in: Modernas Tendencias en la Ciencia del Derecho Penal y la Criminología, UNED, Madrid, 2001, p. 17

188 Cfr. Mário FERREIRA MONTE, O Direito Penal Europeu de "Roma" a "Lisboa" - Subsídios para a Sua Legitimação, Quid Iuris, Lisboa, 2009, p. 81 e ss.

189 Cfr. Jorge de FIGUEIREDO DIAS, O Direito Penal entre a "Sociedade industrial" e a "Sociedade do Risco", in: Estudos em Homenagem ao Prof. Doutor Rogério Soares, BFDUC, Stvdia Ivridica, n. ${ }^{0} 61$, Outubro de 2001, p. 583 e ss.

190 Cfr. Luigi FERRAJOLI, Derecho y Razon, Teoria del Garantismo Penal, 5. ed., Trotta, Madrid, 2005, pp. 358 - 360.

191 Winfried HASSEMER, História das ideias penais na Alemanha do pós-guerra, AAFDL, Lisboa, 1995, pp. 42-50 e 63-82.

192 Anabela MIRANDA RODRIGUES, Política Criminal..., cit., p. 182.

193 Manuel M. GUEDES VALENTE, Direito Penal do Inimigo..., cit., p. 130. 
terrorismo internacional, incutiu nas sociedades a ideia de que o garantismo penal é um obstáculo à eficácia no controlo desses fenómenos e de que vale a pena sacrificar certas garantias para, assim, afirmar a segurança e a tranquilidade públicas. A noção de que se está perante uma criminogénese sem precedentes, à qual não é alheia a percepção do terrorismo transnacional como nova ameaça global, criou a convicção de que os paradigmas juspenais, materiais e processuais, já não são capazes de dar uma resposta eficaz aos novos desafios.

Por outro lado, o advento da pós-modernidade trouxe consigo grandes e novos riscos e a falência da razão técnica e instrumental calculadora no controlo dos mesmos, o que provocou uma acelerada fuga para o direito penal, convertido, assim, em instrumento de controlo de riscos.

Se, do ponto de vista da sua missão, a direito penal do futuro deve ter na protecção dos bens jurídicos socialmente estruturantes o seu pensar fundamental, a sua teleologia legitimadora, não é menos verdade que tal objectivo não pode ser perseguido à custa da dignidade da pessoa humana e das suas liberdades fundamentais. As teorias funcionalistas, deformalizadoras e securitárias, preconizam o ideal da integridade do sistema e a protecção dos bens jurídicos através de diferentes abordagens face aos diversos tipos de criminalidade: seja criando tipos penais de agente, seja abandonando totalmente a função instrumental-material do direito penal, em favor do seu uso como instrumento de segurança. Ora, é aqui que pensamos que o direito penal do futuro corre sérios riscos de se tornar um direito totalitário e fortemente funcionalizado a proporcionar a simples segurança cognitiva, num processo de total obliteração dos princípios do Estado de Direito democrático.

No que concerne à legitimação teleológica, será o direito penal do futuro um sistema sancionatório perfeitamente funcionalizado à gestão do risco e à prevenção geral positiva integradora? Ou deverá permanecer uma ordem normativa votada à defesa das condições da existência humana? Temos por certo que o direito penal não deverá abandonar o seu carácter instrumental. Nenhum modelo penal deve abandonar o bem jurídico como fundamento o padrão crítico do ilícito, de lege ferenda e de jure constituto. Entendemos ser de recusar qualquer proposta que se alicerce numa ideia de funcionalização intensificada do direito penal, que pretenda transformá-lo num instrumento de ordenação social através de uma actuação marcadamente antecipatória na sua tutela: a perseguição penal futura através de medidas de prevenção avançada. ${ }^{194}$

194 Cfr. Manuel M. GUEDES VALENTE, Processo Penal, Segurança e Liberdade: Uma Provocação, Revista Brasileira de Direito Processual Penal, Ano I, n. ${ }^{\circ}$ 1, Janeiro - Junho de 2015, p. 105. Cfr. Hermínio RODRIGUES, op. cit., pp. 56 e ss. 
A toda a norma jurídico-penal estão subjacentes juízos de valor sobre condições vitais para a convivência humana em sociedade, que são, por isso, bens que não podem deixar de considerar-se merecedores de protecção através do poder coercivo do Estado, representado pela proibição ínsita nos tipos penais e pelas penas. Muito embora o conceito jurídico-penal, iluminista e fundacional, de bem jurídico tenha, no contexto da «sociedade do risco», necessariamente, outros contornos, nomeadamente uma natureza supra-individual ou colectiva, a sua exclusiva protecção não pode deixar de ser o fim último e o pensar fundamental do direito penal do futuro. Será, ainda e sempre, a concreta ofensividade aos interesses fundamentais da sociedade que ditará a dignidade penal da conduta, permitindo conservar a identidade do direito penal num equilíbrio entre a mínima intervenção e a antecipação da tutela ao limiar do risco. ${ }^{195}$

Um direito penal funcionalmente orientado à protecção dos bens jurídicos fundamentais não pode deixar de ser um direito penal respeitador das liberdades da pessoa e da sua dignidade em geral. O direito penal do futuro haverá de encontrar o seu referente fundamental no quadro axiológico constitucional dos direitos fundamentais de primeira geração, e encontrar na legalidade e na igualdade os pressupostos inspiradores de toda a sua actuação. Uma dogmática penal e processual penal respeitadora da condição humana do agente só pode ser um direito penal votado à preservação, acima de tudo, da vida, da dignidade humana e da liberdade como valores sociais e jurídicos estruturantes.

Se persistirmos na "heurística do medo" de que nos fala Hans JONAS, iremos em direcção à entropia nas relações humanas, à falta de reconhecimento do rosto do outro. Como diz LEVINAS $^{196}$, o ser não é uma totalidade, mas sim um infinito. Ele não acaba em si mesmo, existe em todos os outros na medida da identificação que entre eles existe. O ser só se realiza e define no rosto do outro, e é, precisamente, a partir da face do outro que encontramos o dever que cabe a cada um de nós e nos faz ser verdadeiramente sujeito ${ }^{197}$. E é por isso que o direito penal do futuro não pode deixar de ter "o rosto da humanidade".

\section{BIBLIOGRAFIA}

AGAMBEN, Giorgio. Homo Sacer: O poder soberano e a vida nua, I, UFMG, Belo Horizonte, 2010. AGUADO, Paz de La Cuesta. Causalidad de los delitos contra el medio ambiente, Tirant lo Blanch, Valencia, 1995. AIRES DE SOUSA, Susana. Risco, precaução e responsabilidade no horizonte da incerteza, in: Estudos em Homenagem ao Professor Doutor José Joaquim Gomes Canotilho, BFD, Studia Juridica n. ${ }^{\circ}$ 102, Coimbra Editora, Coimbra, 2012.

195 Cfr. Hermínio RODRIGUES, op. cit., p. 58.

196 Cfr. Emmanuel LEVINAS, Totalidade e Infinito, Edições 70, Lisboa, 1988, p. 266.

197 Cfr. Idem, ibidem. 
ALBRECHT, Peter Alexis. El Derecho Penal en la intervención de la política populista, in: La Insostenible Situación del Derecho Penal, Comares, Granada, 2000.

ALLER, Germán. El Derecho Penal del Enemigo y La Sociedad de Conflicto, Derecho Penal del Enemigo, Vol. I, MELIÁ; GOMEZ-JARA DIÉZ (coord.), Edisofer, Madrid, 2006.

ALMEIDA, Luís Nunes de. Tolerância, Constituição e Direito Penal, in: Revista Portuguesa de Ciências Criminais, Coimbra Editora, Coimbra, 2013, ano 13, n. ${ }^{\circ} 2$.

AMBOS, Kai. Derecho Penal del Enemigo, in: Derecho Penal del Enemigo, Vol. I, MELIÁ; GOMEZ-JARA DIÉZ (coord.), Edisofer, Madrid, 2006.

ANDERSON, Peter J. Política Global do Poder, Justiça e Morte, Piaget, Lisboa, 1998.

BACELAR GOUVEIA, Jorge. Direito da Segurança, Almedina, Coimbra, 2018.

Dignidade e Pessoa Humana, in: AAVV. Enciclopédia de Direito e Segurança (Bacelar GOUVEIA/ Sofia SANTOS, coord.), Almedina, Coimbra, 2015.

BANDEIRA, Gonçalo N. C. de Melo. Responsabilidade Penal Económica e Fiscal de Entes Colectivos, Almedina, Coimbra, 2004.

BAPTISTA MACHADO, João. Introdução ao Direito e ao Discurso Legitimador, Almedina, Coimbra, 1995.

BARBER, Benjamin, Fear's Empire: War, Terrorism and Democracy, W. W. Worton, New York, 2003.

BAUMAN, Zygmunt. Modernidade Líquida, Zahar, Rio de Janeiro, 2001.

BECK, Ulrich. La Sociedad Del Riesgo Global, Siglo XXI de España, Madrid, 2002. La Sociedad Del Riesgo Mundial: En busca de la seguridad perdida, Paidós, Barcelona, 2008. La Sociedade del Riesgo. Hacia una Nueva Modernidad, Paidós, 1998.

BECKER, Howard S. Outsiders - Estudos de Sociologia Criminal, Zahar, Rio de Janeiro, 2008.

BOBBIO, Norberto. As Ideologias e o Poder em Crise, 4. ${ }^{a}$ ed., UNB, Brasília, 1999.

CABRAL DE MONCADA, Luís. Filosofia do Direito e do Estado, Vol. I, Coimbra Editora, Coimbra, 2. ${ }^{\text {a }}$ ed., 1955.

CAEIRO, Pedro. Cooperação Judiciária na União Europeia, in: Direito Penal Económico e Europeu: Textos Doutrinários, Vol. III, Coimbra: Coimbra Editora, 2009.

Legalidade e oportunidade: a perseguição penal entre o mito da "justiça absoluta" e o fetiche da "gestão eficiente" do sistema, RMP 84, 2000.

CANAS, Vitalino, O Crime de Branqueamento de Capitais - Regime de Prevenção e Repressão, Almedina, Coimbra, 2004.

CANOTILHO, Gomes; MOREIRA, Vital. Constituição da República Portuguesa Anotada, Vol. I, 4. ${ }^{\mathrm{a}}$ ed., Coimbra Editora, Coimbra, 2007.

CANOTILHO, J. J. Gomes. Tomemos a Sério os Direitos Económicos, Sociais e Culturais, BFD, Coimbra, Coimbra Editora, 1988.

CARDOZO POZO, Rodrigo. (Bases de La Política Criminal e Protección Penal de la Seguridad Vial, Universidad de Salamanca, 2009, 509 f., Tese de Doutoramento.

CHEVALIER, J. J.; GUGHET Y. As Grandes Obras Políticas de Maquiavel à Actualidade, Europa-América, Lisboa, 2004.

CORCOY BISADOLO, Mirentxu. (Delictos de Peligro y Protección de Bienes Jurídico-penales Supraindividuales, Valencia, Tirant lo Blanch, 1999.

COSTA ANDRADE, Manuel da. Consentimento e Acordo em Direito Penal, Coimbra Editora, Coimbra, 1991.

DE MASI, Domenico. A Sociedade Pós-Industrial, 3. ${ }^{\text {a }}$ ed., Senac, São Paulo, 2000.

DERRIDA, Jacques. Força de Lei: O fundamento Mítico da Autoridade, Martins Fontes, São Paulo, 2010.

DIAS DUARTE. Branqueamento de Capitais. O Regime do D.L. 15/93 de 22 de Janeiro e a Normativa Internacional, Porto, Universidade Católica, 2002.

DÍEZ RIPOLLÉS, José Luis. De la Sociedad del Riesgo a la Seguridad Ciudadana: Un Debato desenfocado, in: Revista Electrónica de Ciencia Penal y Criminología (RECPC), 07-01, 2005. 
El Nuevo Modelo Penal de la Seguridad Ciudadana, in: Revista Electrónica de Ciencia Penal y Criminología (RECPC) 06-03, 2004.

ESER, Albin. Una justicia penal «A la medida del ser humano» en la época de la europeización y la globalización, in: Modernas Tendencias en la Ciencia del Derecho Penal y la Criminología, UNED, Madrid, 2001.

FARIA COSTA, José de. A Criminalidade em um Mundo Globalizado: ou Plaidoyer por um Direito Penal Não Securitário, in: Direito Penal Económico e Europeu - Textos Doutrinários, Vol. III, IDPEE, Coimbra Editora, Coimbra, 2009. José de. Direito Penal Económico, Quarteto, Coimbra, 2003.

José de. Ler Beccaria Hoje, in: Cesare BECCARIA, Dos Delitos e das Penas, Fundação Calouste Gulbenkian, Lisboa, 1998.

José de. O Fenómeno da Globalização e o Direito Penal Económico, BFDUC, Studia Ivridica, n. ${ }^{0}$ 61, Coimbra Editora, Coimbra, 2001.

, O Fenómeno da Globalização e o Direito Penal Económico, in: Direito Penal Económico e Europeu - Textos Doutrinários, Vol. III, Coimbra Editora, Coimbra, 2009.

FERRAJOLI, Luigi. Derecho y Razón. Teoria del Garantismo Penal, trad. de P. Ibañez et. al., 5. ${ }^{a}$ edição, Trotta, Madrid, 2005.

Democracia y Garantismo, Trotta, Madrid, 2008.

FERREIRA MONTE, Mário. Da Protecção Penal do Consumidor. O problema da (des)criminalização do incitamento ao consumo, Coimbra, Almedina, 1996.

, O Direito Penal Europeu de "Roma" a "Lisboa" - Subsídios para a Sua Legitimação, Quid Iuris, Lisboa, 2009.

, O Futuro tem Direito Penal? O Direito Penal tem futuro? Apontamento introdutório à obra de Paulo S. FERNANDES, Globalização, "Sociedade de Risco" e o Futuro do Direito Penal, Almedina, Coimbra, 2001.

FIGUEIREDO DIAS, Jorge de. Direito Penal - Parte Geral. Questões Fundamentais. Teoria Geral do Crime, Coimbra Editora, Coimbra, 2004.

,Direito Penal - Parte Geral. Questões Fundamentais. Teoria Geral do Crime, 2. a edição, Coimbra Editora, Coimbra, 2007.

, O Direito Penal entre a "Sociedade industrial" e a "Sociedade do Risco", in: Estudos em Homenagem ao Prof.

Doutor Rogério Soares, BFDUC, Studia Ivridica, n. ${ }^{\circ} 61$, Outubro de 2001. Temas Básicos da Doutrina Penal, Coimbra Editora, Coimbra, 2001.

FREELEY, M. / SIMON J. Actuarial Justice: The Emerging New Criminal Law, in: Crime and the Risk Society, O’MALLEY (org.) 1998.

FREELEY, M. / SIMON, J. The New Penology: Notes on the Emerging Strategy of Corrections and Its Implications, 30, Criminology 449, 470 (1992).

FREITAS DO AMARAL, Diogo. Do 11 de Setembro à Crise do Iraque, Bertrand, Lisboa, 2003. História das Ideias Políticas, Almedina, Coimbra, 1999.

GIDDENS, Anthony. As Consequências da Modernidade, Celta, Lisboa, 1992. , O Mundo na Era da Globalização, Editorial Presença, 2000.

GRACIA MARTIN, Luis. Consideraciones Críticas Sobre al Actualmente Denominado Derecho Penal del Enemigo, in: Revista Electrónica de Ciencia Penal y Criminología (RECPC) 07-02, 2005. , El horizonte del finalismo y el derecho penal del enemigo, Tirant Lo Blanch, Valencia, 2005.

GUEDES VALENTE, Manuel M. Contributos para um Direito Penal Supranacional, 3. ${ }^{\text {a }}$ ed., Legit, s/l, 2018. , Direito Penal do Inimigo e o Terrorismo, $2 .^{\text {a }}$ ed., Almedina, Coimbra, 2017.

Processo Penal, Segurança e Liberdade: Uma Provocação, Revista Brasileira de Direito Processual

Penal, Ano I, n. ${ }^{\circ}$, Janeiro - Junho de 2015. 
La Política Crimina y la Criminología en Nuestros Dia. Una Visión Desde Portugal, in: Derecho Penal y Criminología como Fundamento da la Política Criminal. Estudios en Homenaje al Prof. Alfonso Serrano Gómez, Dickinson, Madrid, 2006.

GÜNTHER, Klaus. De la vulneración de un derecho a la infracción de un deber: un cambio de paradigma en el Derecho Penal?, in: La Insostenible Situación del Derecho Penal, Comares, Granada, 2000.

HASSEMER, Winfried / MUÑOZ CONDE, Francisco. La Responsabilidad por el Producto en Derecho Penal, Tirant lo Blanch, Valencia, 1995.

Perspectivas del Derecho Penal Futuro, Revista Penal, Universidad de Huelva, 1998.

História das ideias penais na Alemanha do pós-guerra, AAFDL, Lisboa, 1995. A Segurança Pública no Estado de Direito, AAFDL, 1995. Contra el abolicionismo: acerca del porqué no se deberia suprimir el derecho penal, RP, n. ${ }^{\circ} 11,2003$. Crisis y características del moderno derecho penal. Actualidad Penal, n 43/22, Madrid, 1993. Lineamentos de una teoría personal del bien jurídico, DP, Año 12, 1989. Persona, mundo y responsabilidad. Bases para una teoría de la imputación en Derecho Penal, trad. de F. Muñoz Conde y M.M. Díaz Pita, Tirant lo Blanch, Valencia, 1999.

HEFENDEHL, Roland. Debe Ocuparse El Derecho Penal de Riesgos Futuros? Bienes Jurídicos Colectivos y Delictos de Peligro Abstracto, in: Anales de Derecho, n. ${ }^{\circ}$ 19, Universidad de Murcia, 2001.

HERZOG, Felix. Limites del Derecho Penal para controlar los riesgos sociales, in: Poder Judicial n. ${ }^{\circ} 32,1993$.

JAKOBS Günther; CANCIO MELIÁ, Manuel. Derecho Penal del Enemigo, Cuadernos Civitas, Madrid, 2003. La Ciencia Penal ante los Retos del Futuro, in: Albin ESER / Winfried HASSEMER / Björn BURKHARDT, La ciencia del Derecho Penal ante el cambio de Milenio, Trad. de Teresa MANZO, Francisco MUÑOZ CONDE (Coord.), Valencia, 2004.

Sobre la Normativización de la Dogmática Jurídico-Penal, trad. CANCIO MELIÁ / FEIJÓO SANCHÉZ, Thomson-Civitas, Madrid, 2003.

INNERARITY, Daniel. A Sociedade Invisivel, Teorema, Lisboa, 2009.

JESCHECK, Hans. Tratado de Derecho Penal, Barcelona, Bosch, 1981.

JONAS, Hans. El principio de responsabilidad: ensayo de una ética para la civilización tecnológica, Herder, Barcelona, 1995 .

KANT, Emmanuel. A Paz Perpétua e outros Opúsculos, trad. Artur Mourão, Edições 70, Lisboa, 1989.

KAUFMANN, Arthur. Filosofia do Direito, 5. ${ }^{\text {a }}$ ed., Fundação Calouste Gulbenkian, Lisboa, 2014.

KEMPF-LEONARD / PETERSON, Expanding Realms of the New Penology - The Advent of Actuarial Justice for Juveniles, in: Punishment \& Society, vol. 2, n. ${ }^{\circ} 1$, January 2000.

LAMAS LEITE, André. Nova penologia, punitive turn e direito criminal: quo vadimus? Pelos caminhos da incerteza (pós-)moderna, in: Direito Penal - Fundamentos Dogmáticos e Político-Criminais - Homenagem ao Prof. Peter Hünerfeld, Coimbra Editora, Coimbra, 2013.

, André. Nueva Penologia, Punitive Turn y Derecho Penal: Quo Vadimus? Por la Incertidumbre (Pos) Moderna, in: InDret - Revista para el analisis del Derecho, nr. 2, Barcelona, 2013.

LEVINAS, Emmanuel. Totalidade e Infinito, Edições 70, Lisboa, 1988

LÓPEZ CALERA, Nicolás Maria. Hay derechos colectivos? Individualidad y socialidade en la teoria de los derechos colectivos, Barcelona, Ariel, 2000.

LUCAS PIRES, Francisco. Introdução ao Direito Constitucional Europeu, Almedina, Coimbra, 1997.

LUHMANN, Niklas, Risk: A Sociological Theory, Walter De Gruyter, Berlin-New York, 1993.

MAILLARD, Jean de, Crimes e Leis, Piaget, Lisboa, 1995.

MANTOVANI, Fernando. Diritto Penale, Pádova, CEDAM, 2001.

Fernando. Princípio di ofensivitá tra dogmatica e politica criminale, in: Il Diritto Penale alla Svolta di Fine Millenio, G. Giappichelli Editore, Torino, 1998. 
MARINUCCI / DOLCINNI, Diritto penale minimo e nuove forme de criminalitá, Rivista Italiana di Diritto e procedura penale, 1999 .

MÁRTINEZ-BUJAN PEREZ, Carlos. Derecho Penal Económico - Parte General, Tirant lo Blanch, Valencia, 1998.

MATA Y MARTÍN, Ricardo M. Bienes jurídicos intermedios y delitos de peligro: aproximación a los presupuestos de la técnica de peligro para los delitos que protegen bienes jurídicos intermedios, Comares, Granada, 1997.

MIR PUIG, Santiago. Bases constitucionales del Derecho penal, Marcial Pons, Madrid, 2011.

MIRANDA RODRIGUES, Anabela. Criminalidade Organizada - Que Política Criminal?, in: Direito Penal Económico e Europeu - Textos Doutrinários, III vol., IDPEE, Coimbra Editora, Coimbra, 2009, p. 187.

Política Criminal - Novos Desafios, Velhos Rumos, in: Direito Penal Económico e Europeu - Textos Doutrinários, III vol., IDPEE, Coimbra Editora, Coimbra, 2009.

Política Criminal - Novos Desafios, Velhos Rumos, in: Liber Discipulorum para Figueiredo Dias, Coimbra Editora, Coimbra, 2003.

O Mandado de Detenção Europeu - Na Via da Construção de um sistema penal europeu: um passo ou um salto?, in: O Direito Penal Europeu Emergente, Coimbra Editora, Coimbra, 2008.

, A Emergência de um "Direito Penal Europeu" - Questões Urgentes de Política Criminal, in: O Direito Penal Europeu Emergente, Coimbra Editora, Coimbra, 2008.

MIRANDA, Jorge. Manual de Direito Constitucional, Tomo IV, 3. ${ }^{\text {a }}$ ed., Coimbra Editora, Coimbra, 2000.

MOCCIA, Sergio. De la tutela de bienes a la tutela de funciones: entre ilusiones postmodernas y reflujos iliberales, in: Política Criminal y Nuevo Derecho Penal (libro homenaje a Claus Roxin), Bosch, Barcelona, 1997.

MOTA PINTO, Paulo. Nota sobre o imperativo da tolerância' e seus limites, in: Estudos em Memória do Conselheiro Luís Nunes de Almeida, Coimbra Editora, Coimbra, 2007.

MUÑOZ CONDE, Francisco. El nuevo Derecho penal autoritario, in: El Derecho ante la globalización y el terrorismo, AA. VV., Tirant lo Blanch, Valencia, 2004.

El nuevo Derecho penal autoritario: consideraciones sobre el llamado Derecho penal del enemigo, in: Mutaciones de Leviatán. Legitimación de los nuevos modelos penales, AA. VV., Akal, Madrid, 2005.

Protección de Bienes Jurídicos como Limite Constitucional al Derecho Penal, Quintero Olivares /

Morales Prats (Coords.). El Nuevo Derecho Penal Español Estudios Penales en Memoria del Profesor José Manuel Valle Muñiz, Editorial Aranzadi, Madrid, 2001.

Protección de Bienes Jurídicos como Limite Constitucional al Derecho Penal, Quintero Olivares I Morales Prats (Coords.). El Nuevo Derecho Penal Español Estudios Penales en Memoria del Profesor José Manuel Valle Muñiz, Editorial Aranzadi, Madrid, 2001.

OST, François. O Tempo do Direito, Piaget, Lisboa, 2001.

NAUCKE, Wolfgang. La progressiva pérdida de contenido del princípio de legalidade penal como consecuencia de um positivismo relativista y politizado, in: La Insostenible Situación del Derecho Penal, Comares, Granada, 1993.

PERELMAN, Chäim. Ética e Direito, Piaget, Lisboa, 2002.

PÉREZ, Jesus González. La Dignidad de la Persona, Civitas, Madrid, 1986.

POLAINO-ORTS, Miguel. Derecho Penal del Enemigo. Fundamentos, Potencial de Sentido y Limites de Vigencia, Bosch, Barcelona, 2009.

PRITTWITZ, Cornelius. El Derecho Penal Alemán: ¿fragmentario? ¿subsidiario? ¿ultima ratio? Reflexiones sobre la razón y límites de los principios limitadores del Derecho penal", in: La insostenible situación del Derecho penal, AA. VV., trad. Maria Teresa Castiñeira Palou, Granada, Comares, 2000.

O Direito Penal entre o Direito Penal do Risco e o Direito Penal do Inimigo: Tendências Actuais em Direito Penal e Política Criminal, in: Revista Brasileira de Ciências Criminais, São Paulo, Revista dos Tribunais - n. ${ }^{\circ} 47$, IBCCRIM, Mar/Abr. 2004. 
, Sociedad del Riesgo y Derecho Penal, in: ARROYO ZAPATERO / NEUMANN / NIETO MARTÍN, Crítica y justificación del Derecho penal en el cambio de siglo. El análisis crítico de la Escuela de Frankfurt, Universidad de Castilla-La Mancha, Cuenca, 2003.

PUREZA, José Manuel. O Património Comum da Humanidade - Rumo a um Direito Internacional da Solidariedade, Afrontamento, Lisboa, 1998.

RODRIGUES, Hermínio C. S., Responsabilidade Penal de Pessoas Colectivas: Uma Revisitação à Luz da Teoria do Risco. Lisboa: Universidade Autónoma de Lisboa, 2016, 122 p. Dissertação de Mestrado (polic.)

ROSAL BLASCO, Bernardo del. Hacia un Derecho Penal de la Postmodernidad?, in: Revista Electrónica de Ciencia Penaly Criminología, 2009, n. ${ }^{\circ} 11-08$.

ROXIN, Claus. ¿Es la protección de bienes jurídicos una finalidad del Derecho penal?, in: Roland HEFENDEHL, (Ed.), La teoría del bien jurídico: ¿Fundamento de legitimación del Derecho penal o juego de abalorios dogmático? Marcial Pons, Madrid, 2007.

, Derecho Penal, trad. Luzón Peña, Garcia Conledo, Vicente Remesal, Civitas, Madrid, reimp. 2000. Derecho Penal. Parte General. Tomo I. Fundamentos. La estructura de la Teoría del Delito, Traducción de LUZÓN-PEÑA; García CONLLEDO; Vicente REMESAL, Civitas, Madrid, 1997.

SCHMITT, Carl. Teologia Política, Trotta, Madrid, 2009.

SCHNEIDER, Hans. Recientes investigaciones criminológicas sobre la criminalidad organizada", in: Revista de Derecho Penal y Criminologia, 3, 1993.

SCHÜNEMANN, Bernd. Consideraciones críticas sobre la situación espiritual de la ciencia jurídico-penal alemana, in: Annuario de Derecho Penal y Ciencias Penales, n. ${ }^{\circ}$ 49, fasc. 1, Jan. - Abril, San Bernardo, Madrid, 1996.

El principio de protección de bienes jurídicos como punto de fuga de los limites constitucionales de los tipos penales $y$ de su interpretación, in: Roland HEFENDEHL, (Ed.). La teoria del bien jurídico: ¿Fundamento de legitimación del Derecho penal o juego de abalorios dogmático?, Marcial Pons, Madrid, 2007.

SCHULZ, Lorenz. De la aceleración de las condiciones de vida, in: La Insostenible Situación del Derecho Penal, Comares, Granada, 1999.

SERRA DE CARVALHO, Hamilton. Estado Forte - Hobbesianismo e Maquiavelismo na Ordem Político-Constitucional Global, Chiado Editora, Lisboa, 2016.

SILVA DIAS, Augusto. De que Direito Penal Precisamos Nós Europeus? Um olhar sobre algumas propostas recentes de constituição de um direito penal comunitário, in: RPCC, Coimbra Editora, Coimbra, 2004, ano 14, n. ${ }^{\circ} 3$. , Delicta in se e delicta mere prohibita: uma análise das descontinuidades do ilícito penal moderno à luz da reconstrução de uma distinção clássica, FDUL Lisboa, 2003.

Entre «comes e bebes»: debate de algumas questões polémicas no âmbito da proteç̧ão jurídico-penal do consumidor (a propósito do acórdão da Relação de Coimbra de 10 de Julho de 1996), in: RPCC, ano VIII, 1998, n. ${ }^{\circ} 4$ e RPCC, ano 9, 1999.

Os crimes de fraude fiscal e de abuso de confiança fiscal: alguns aspectos dogmáticos e político-criminais, in: Ciência e Técnica Fiscal, n. ${ }^{\circ}$ 394, 1999.

Protecção Jurídico-Penal do Interesses dos Consumidores, $3 .^{\text {a }}$ ed. policop., FDUC - IDPEE, Coimbra, 2001.

SILVA FRANCO, A. Globalização e Criminalidade dos Poderosos, RPCC, Ano 10 - Fasc. 2. ${ }^{\circ}$, Abril - Junho de 2000.

SILVA PEREIRA, Maria Margarida. Direito Penal - Direito do Risco, Comparticipação Crimininosa, Tráfico de Influência, Quid Iuris, Lisboa, 2012.

SILVA-SÁNCHEZ, Jesús Maria. La Expansión del Derecho Penal. Aspectos de la Política Criminal en las Sociedades Postindustriales, Civitas, Madrid, 1999.

STELLA, Federico. Giustizia e Modernitá. La Protezione dell' Inoccente e la Tutela delle Vittime, Giuffre Editore, Milano, 2002. 
TAVARES, Juarez. A Globalização e os Problemas de Segurança Pública, in: Revista da Associação Brasileira de Professores de Ciências Penais, São Paulo, ano 1, n. ${ }^{\circ}$ oo, 2004.

TIEDEMANN, Klaus. Lecciones de Derecho Penal Económico, PPU, Barcelona, 1993.

TORRAINE, Alain. Crítica da Modernidade, Piaget, Lisboa, 1994.

VIEIRA DE ANDRADE, José Carlos. Os Direitos Fundamentais na Constituição Portuguesa de 1976, 3. ${ }^{a}$ ed., Almedina,

Coimbra, 2004.

ZÚÑIGA RODRIGUEZ, Laura. Política Criminal, Colex, Madrid, 2001.

ZUÑIGA RODRIGUEZ, Laura. Redes Internacionales y Criminalidad: a Propósito del Modelo de Participación en Organización Criminal, in: El Derecho Penal Ante La Globalización, ZUÑIGA RODRIGUEZ, Laura / MENDEZ RODRIGUEZ, Cristina / DÍAZ-SANTOS, M. Rosario (coords.), Colex, Madrid, 2002. 


\section{RECENSÖES
REVIEWS

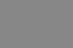
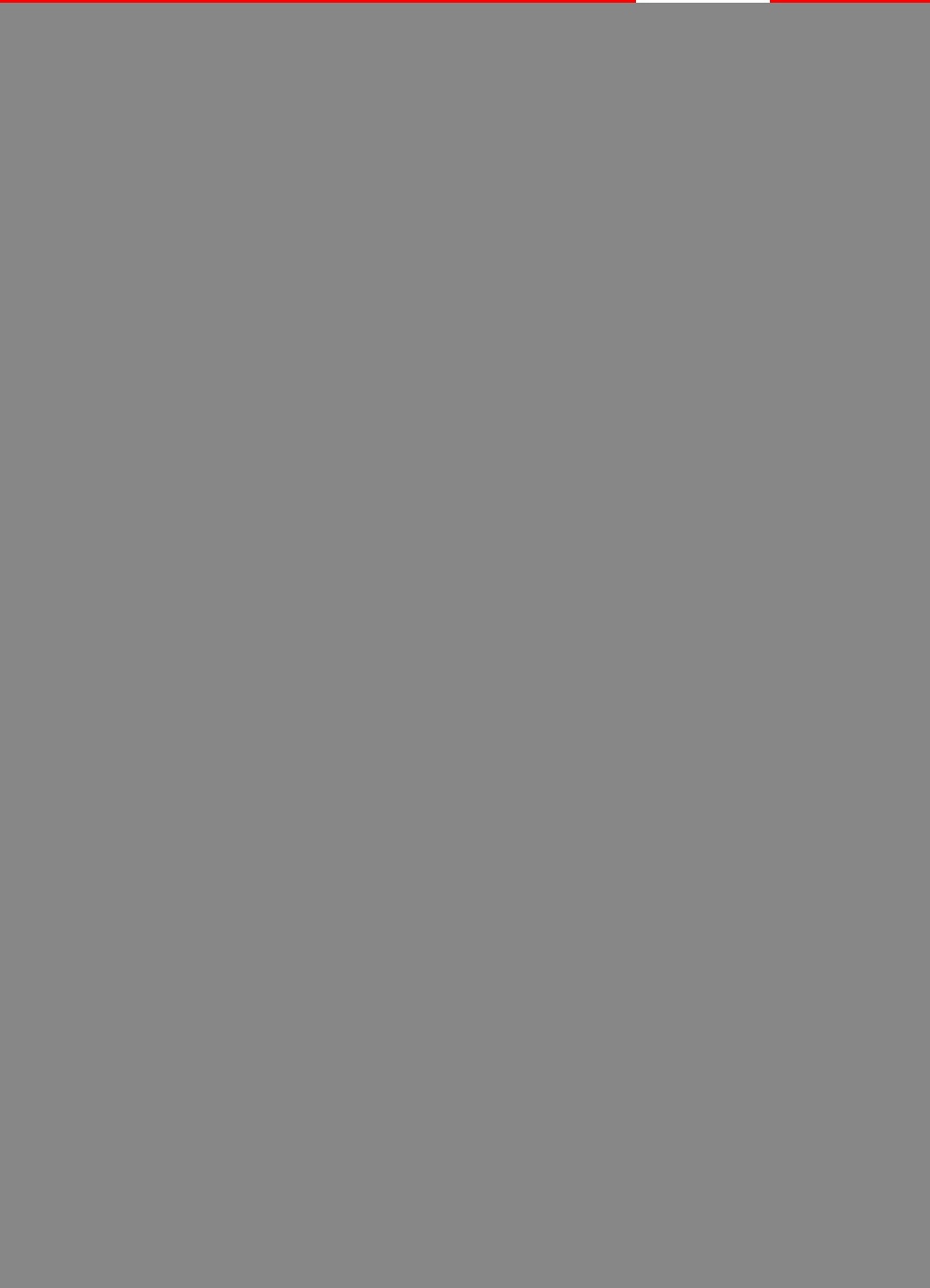

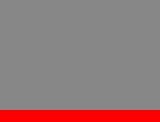

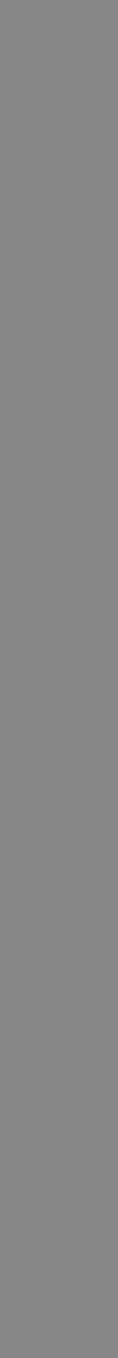




\title{
RECENSÃO BIBLIOGRÁFICA
}

\section{PIRES, Alex Sander; ROSÁRIO, Pedro Trovão do; BAHAMONDE, Ruben. (Org.) Compliance: perspectivas e novas dinâmicas. Coimbra: Almedina, 2019. 101 p. ISBN 978-972-40-8268-4.}

\author{
POR RODRIGO LUÍS ZIEMBOWICZ*
}

rlzdireito@hotmail.com

GALILEU - REVISTA DE DIREITO E ECONOMIA - e-ISSN 2184-1845

Volume XX - $1^{\text {st }}$ July Julho $-31^{\text {TH }}$ December Dezembro $2019 \cdot$ pp. 199-202

DOI: http://doi.org/10.26619/2184-1845.XX.2.1.01

Esta obra resulta de uma soma de esforços do Centro de Investigação Ratio Legis, do Departamento de Direito da Universidade Autónoma de Lisboa, do Instituto Universitário do Rio de Janeiro e do Ethical \& Compliance International Institute, consolidando o conteúdo e os debates promovidos em dois congressos jurídicos, realizados em Lisboa (Portugal) e no Rio de Janeiro (Brasil), tendo por temática o sistema de compliance, com ênfase na sua interconexão com a cultura de paz e com a dignidade humana. $\mathrm{O}$ assunto é relevante e atual, representando um tema discutido de forma constante e crescente na seara acadê- mica, bem como nas instituições estatais e privadas.

Efetivamente, passada mais de uma década do início da recessão econômica de escala global, ${ }^{1}$ é chegado o momento de reencontrar o equilíbrio no ordenamento jurídico, na definição das políticas estatais (especialmente criminais, administrativas e econômicas), bem como nas relações privadas, com base nos mais elevados valores e padrões éticos, lastreados na dignidade da pessoa humana e nos efeitos que devem irradiar desta convicção. Nesse aspecto, a presente obra, elaborada por juristas, acadêmicos e

\footnotetext{
1 A partir dos abalos econômicos que surgiram na década passada, principalmente a partir do colapso financeiro (de alcance global) de 2008, que ainda produz efeitos negativos nas economias de muitos países, causando prejuízos evidentes à qualidade de vida das pessoas (principalmente das menos afortunadas), a sociedade vem rediscutindo e buscando aperfeiçoar (especialmente) os seus sistemas financeiros (privados e públicos) e as políticas econômicas. Revelou-se, numa clara e nova dinâmica social, que não são mais tolerados os constantes prejuízos econômicos e sociais impingidos ou diluídos entre todos os indivíduos (direta ou indiretamente), quando os lucros de manobras financeiras e empresariais nocivas e imorais (embora nem sempre ilegais) são concentrados entre pouquíssimos indivíduos. Efetivamente, houve (inclusive) uma nítida expansão do Direito Penal e de outros ramos jurídicos, com o fito de prevenir, detectar e também sancionar as condutas que lesionem (ou coloquem em grave risco) bens jurídicos relevantes, de cariz coletiva. Visa-se, de fato, a estabelecer um certo controle mínimo e acompanhamento sobre pessoas físicas e coletivas, atividades políticas, econômicas e mercados, que possuíam pouca ou nenhuma regulação, deficiência esta que viabilizou, em grande medida, o desequilíbrio financeiro que resultou na grande recessão econômica que, infelizmente, ainda produz efeitos danosos.
} 
profissionais do Direito de Portugal, do Brasil e da Espanha, oferece uma perspectiva diferenciada quanto ao compliance, compreendido como paradigma e programa de integridade, que tem evoluído e proporcionado tanto a criação quanto a constante ampliação das medidas, a serem adotadas por agentes públicos e privados, no sentido de prevenir e evitar o desatendimento a normas e a princípios éticos estabelecidos nos respectivos ordenamentos jurídicos e em códigos de conduta. Com efeito, esta adoção de boas práticas tem envolvido tanto os órgãos públicos quanto a sociedade civil na busca por relações humanas e institucionais íntegras, com maior responsabilidade e, obviamente, um fortalecimento ético das ações (e omissões) individuais e coletivas.

Nesse rumo, os sete textos que compõem este livro analisam o compliance sob a perspectiva da cultura de paz e da dignidade da pessoa humana, ${ }^{2}$ sob diversos matizes.

A primeira abordagem, intitulada "O compliance como instrumento para o fortalecimento da cultura de paz", manuscrita pelo também organizador Alex Sander Pires, apresenta um escorço histórico e examina as iniciativas e os instrumentos utilizados pelas Nações Unidas para estabelecer um sistema de paz a nível mundial, entendido como uma "reunião de povos" com fins humanitários, com o firme propósito de manter a paz, promover a segurança internacional e viabilizar o exercício dos direitos fundamentais. Após, apresenta reflexões sobre a aproximação do compliance ao sistema de cultura de paz, tanto no aspecto normativo quanto ideológico, analisando o envolvimento de diferentes setores da sociedade nessa busca do resgate moral dos indivíduos, no fortalecimento da ética e de uma consciência coletiva através da educação.

O texto seguinte, "A era do compliance no século XXI", de Cláudio Carneiro, investiga os escândalos de corrupção de maior repercussão internacional, envolvendo agentes públicos e empresas transnacionais, bem como o desenvolvimento de instrumentos de gestão e de políticas de boa governança por organismos internacionais, os quais objetivam a promoção de uma cultura sustentável de integridade. Posteriormente, apresenta diversos aspectos dos programas de compliance, desde princípios e regras de conduta ética até medidas para ampliar e aperfeiçoar a transparência e a difusão de informações ao público, facilitados pela tecnologia digital moderna. Prosseguindo, traz a lume diversos pontos de reflexão, inclusive quanto à necessidade de gerenciamento de riscos, de modo a evitar condutas ilícitas ou não condizentes com os

2 Na apresentação, o organizador e autor Pedro Trovão do Rosário anota que o sistema da cultura de paz das Nações Unidas foi concebido para, entre outras diretrizes, difundir uma educação voltada para o aperfeiçoamento ético e normativo das relações entre os seres humanos, bem como uma resolução pacífica dos conflitos e a adoção de instrumentos que aumentem a transparência e a responsabilidade dos atores governamentais e privados, envolvendo todos os indivíduos, conceitos esses que possuem forte interligação com o compliance. 
valores, visão e objetivos de empresas e de órgãos públicos.

Por seu turno, "O compliance trabalhista como mecanismo de promoção do trabalho decente e de aperfeiçoamento da dinâmica corporativa", de Fábio Goulart Villela, examina a evolução da sociedade (ocidental), a qual culminou no reconhecimento da dignidade da pessoa humana como o valor central da ordem jurídica internacional, irradiando os seus efeitos sobre as mais diversas constituições de Estados Democráticos de Direito. Pondera o autor que o direito a um trabalho decente é um dos mais importantes fatores para promover a concreção da dignidade humana, passando a analisar e propor o debate sobre as suas nuances em relação ao compliance trabalhista. Trouxe à tona, ainda, a discussão sobre os pilares de sustentação de um sistema de integridade que, além de uma cultura de conformidade e ética, deve viabilizar um trabalho digno para o trabalhador e a otimização da dinâmica das empresas.

A análise sobre "O compliance e os Estados europeus", de Pedro Trovão do Rosário, um dos organizadores da obra, investiga o atendimento das normas da União Europeia pelos Estados-membros, inclusive quanto à efetiva transposição e aplicação da legislação estabelecida nos prazos fixados, além de abordar os procedimentos em caso de infração e os efeitos decorrentes dessa conduta. Debruça-se o autor, ainda, sobre outras questões de enorme relevância, como a recomendável adoção pelos Estados-membros de um sistema de compliance (da mesma forma que milhares de empresas europeias) para corrigir suas deficiências, acompanhar regularmente suas obrigações e prevenir violações e outras condutas irregulares no seio da UE. Ademais, traz ao debate alguns exemplos de normas rigorosas, que preveem elevadas sanções de caráter administrativo ou penal em caso de descumprimento de normas de compliance por pessoas jurídicas (ou equiparadas), ao tempo em que os Estados-membros descumprem reiteradamente a legislação da UE sem que lhes seja exigida adoção de um programa de integridade, impondo-se a discussão sobre o tema no seio da sociedade europeia.

$\mathrm{O}$ autor Ruben Bahamonde, que também participou da organização do livro, apresentou o texto "Antitrust compliance", no qual investiga a integridade do comportamento de empresas e dos seus representantes em relação ao direito concorrencial. Pondera, principalmente, fatores relativos aos custos e benefícios da implantação de um sistema de integridade, em busca da difusão e do atendimento de regras de conduta dirigidas não somente aos diretores e operadores jurídicos das empresas, mas também aos demais setores, como administradores intermédios, sócios e trabalhadores. Traz a lume, ainda, pontos relacionados aos prejuízos econômicos causados às empresas pelo descumprimento de normas (ambientais, fiscais, trabalhistas e outras), diante dos danos à reputação do empreendimento no mercado e da aplicação de sanções. Após, trata do regime de concorrência europeu e brasileiro, investigando os ilícitos concorrenciais, apresentando 
diversos casos para estudo e seus respectivos dados, acrescentando ao debate as principais características e modelos de compliance.

$\mathrm{O}$ artigo "El compliance corporativo y la seguridade jurídica, hacia un nuevo derecho", de Maria Teresa Posada Fernández, analisa as normas do ordenamento jurídico espanhol relativas aos programas de cumplimiento normativo, especialmente quanto às possibilidades de atenuar ou de eximir as pessoas jurídicas (e também físicas) de uma responsabilização criminal. Perscruta, também, o compliance entendido como uma cultura corporativa, objetivando evitar ou diminuir riscos, gerar segurança jurídica e otimizar o empreendimento. Prosseguindo, adiciona à discussão uma avaliação histórica europeia sobre o tema e a importância de sistemas efetivos de cumprimento de normas e de prevenção a delitos, abordando os respectivos benefícios e os danos que podem decorrer da sua falta, principalmente quanto à responsabilização penal de uma empresa ou dos seus componentes.

O estudo intitulado "O compliance trabalhista como instrumento de transformação cultural para a dignidade humana", de Valéria Ribeiro Bruno, examina a evolução da cultura de integridade, voltada para o cumprimento do ordenamento jurídico e para o atendimento a princípios éticos nas organizações. Indica, também, o seu potencial como instrumento para otimizar e fortalecer tanto as empresas quanto os órgãos públicos, ao desenvolver honestidade, comprometimento, competência e transparência no seio das instituições. Como meio de aprimoramento organizacional nas relações trabalhistas, analisa as técnicas de compliance e os benefícios que pode ofertar a todos os envolvidos, quer seja no processo de contratação, quer seja durante o exercício laboral e, inclusive, após o término do contrato de trabalho. Traz à discussão, também, a conexão entre esta promoção de um sistema integridade legal e ética e a dignidade humana.

Desse modo, conclui-se que esta obra, além de examinar múltiplas facetas e características do sistema ou cultura de compliance, tem elevado mérito por trazer à baila uma série de pontos de reflexão sobre o tema, voltando-se principalmente ao aperfeiçoamento de instituições privadas e públicas, cooperando, assim, para o aperfeiçoamento da comunidade humana. Os textos ofertam, ainda, diversos aspectos relativos à necessidade de modificar a cultura jurídica ocidental, no sentido de valorizar e utilizar métodos preventivos e consultivos, em detrimento de uma tendência de resolução de problemas através do contencioso judicial, que resulta num elevado custo para as empresas, para o Estado e para o tecido social como um todo.

* Doutorando em Ciências Jurídicas da Universidade Autónoma de Lisboa

\section{Como citar esta Recensão Bibliográfica:}

ZIEMBOWICZ, Rodrigo (2020). Recensão Crítica de: PIRES, Alex Sander; ROSÁRIO, Pedro Trovão do; BAHAMONDE, Ruben. (Org.). Compliance: perspectivas e novas dinâmicas. Coimbra: Almedina, 2019. 101 p. ISBN 978-972-40-8268-4. 


\section{RECENSÃO CRÍTICA}

\section{VALENTE, Manuel Monteiro Guedes (Coord.). Os desafios do direito do século XXI: violência, criminalização, consenso, tutela digital e laboral. Coimbra: Almedina, 2019. 196 p. ISBN 978-972-40-8224-0.}

\section{EMANUEL CARVALHO}

emanuelcarvalho-44900p@adv.oa.pt

GALILEU - REVISTA DE DIREITO E ECONOMIA - e-ISSN 2184-1845

Volume XX · $1^{\text {st }}$ July Julho $-31^{\text {TH }}$ December Dezembro 2019 . pp. 203-208

DOI: http://doi.org/10.26619/2184-1845.XX.2.1.02

Renasce a obra "Os desafios do direito do século XXI", focada agora na "violência, criminalização, consenso, tutela digital e laboral", para prosseguir a linha de investigação Law and Governance do Ratio Legis - Centro de I\&D em Direito da Universidade Autónoma de Lisboa (UAL), e firmar os conteúdos debatidos em três eventos científicos realizados em fevereiro de 2019 na UAL, nos quais participaram professores e investigadores portugeses e estrangeiros, alunos de cursos de Mestrados e Doutoramento da UAL, que têm comungado ou cooperado em projectos do Ratio Legis.

Edificada por ilustres académicos e profissionais do Direito, a obra eleva questões prementes, relevantes e até sensíveis considerando, lato sensu, a colisão entre direitos e garantias fundamentais, pelo que crê-se, seguramente, ter sido tão desafiante para aos autores dissertar como será uma preciosidade para os interessados absorver os seus pensamentos. E, assim, fomenta-se a partir de um ambiente doutrinal e profissional, bem como na esteira de instituições privadas e públicas, a reflexão e a (re)construção de respostas que evitem sacrifícios e retrocessos no caminho até agora trilhado, após as sucessivas guerras mundiais ocorridas do século XX, de crescente valorização do ser humano que promove a paz e segurança na comunidade, bem como o desenvolvimento social, económico e cultural da pessoa assente em direitos fundamentais.

A temática abordada realça um modus vivendi hodierno marcadamente global e digital, no qual têm emergido novas e complexas formas de violência e, consequentemente, tem sido marcado pela crescente violação de direitos, liberdades e garantias fundamentais,

$11 .^{\text {a }}$ edição: VALENTE, Manuel Monteiro Guedes (Coord.). Os desafios do direito (penal) do século XXI. Lisboa: Legit, 2018. 236 p. ISBN 978-972-8973-51-3.

2. ${ }^{a}$ edição: VALENTE, Manuel Monteiro Guedes (Coord.). Os desafios do direito do século XXI: genoma humano, europeísmo, poder e política, constituição e democracia. Lisboa: Almedina, 2018. 240 p. ISBN 978-972-40-7746-8. 
que justificam repensar e, qui sapit, redescobrir o Direito para, com os seus princípios e normas, refundar-se o ordenamento jurídico no sentido de, ao longo do século XXI, ser possível promover uma cultura de paz transnacional e uma sociedade assente na tutela da dignidade da pessoa humana.

Neste sentido, os nove artigos que dão corpo ao livro ramificam-se numa primeira parte que analisa conjugadamente o direito (penal) vigente e o modo dissimulado da violência contemporânea. E noutra parte que, por seu turno, subdivide-se em dois temas relacionados com a tutela da personalidade, sendo que o primeiro está associado ao espaço digital (analisando ora a protecção e gestão dos dados pessoais, ora a autotutela) e o segundo ao domínio laboral (confrontando a dimensão jurídica da pessoa no mercado de trabalho com a elevada informativação dos seus procedimentos e a crescente presença da inteligência artificial).

O primeiro estudo, intitulado "A matriz oculta da violência na modernidade", foi redigido por Ruth Chitó Gauer, Professora da PUCRS², e propõe, numa linha de pensamento jus-filosófica, uma reflexão sobre o paradoxo da liberdade contemporânea. Interpreta, assim, a liberdade individual como sendo proporcional à necessidade de normatização das condutas sociais, das quais pululam direitos e, em particular, se promove a igualdade entre (todas) as pessoas, a qual, ine- xoravalemente, será garantida desde que haja respeito pelas diferenças individuais. Deste modo, seja pela via da normatização, seja pelo risco de segregação, o indíviduo hodierno condiciona a sua liberdade para sujeitar-se ao poder (decisório ou punitivo) da autoridade (leia-se do Estado) ou à vontade da maioria (leia-se da comunidade), restando-lhe eticamente um ínfimo espaço de afirmação singular. Estaremos a construir um novo modelo de Estado de Direito ou de "Não Direito", eis o desafio que urge reflectir.

$\mathrm{O}$ artigo seguinte, da autoria de Fernanda Martins, Professora na UNIVALLI ${ }^{3}$, explora a partir de uma perspectiva subjectiva, centrada na mulher, o binómio que aparta as figuras do agente e da vítima de crime com vista a construir uma "nova" categoria conceptual que se dá pelo nome que compõe o tema apresentado: "Feminismos criminológicos". E a autora desafia o pensamento jurídico enraízado no Brasil que associa a mulher ao papel de vítima, defendendo que a construção de políticas criminais e a edificação de um sistema penal igualitário necessita de ser centrado entre, por um lado, o raio definido pela referida linha tradicional de pensamento jurídico e, por outro, o raio delineado pela visão da mulher enquanto agente de crime, sendo que todo o espaço que preenche a circunferência constitui o conceito que propõe. Da teoria - seja feminista ou oposta - há habitualmente uma distância e as pontes

\footnotetext{
2 Pontifícia Universidade Católica do Rio Grande do Sul.

3 Universidade do Vale do Itajaí.
} 
poderão ser construídas a partir de conceitos estereotipados ou singulares baseados estes na matriz que nos une - a humanidade.

Por seu turno, o Professor da PUCRS 4 , Augusto Jobim do Amaral, e a Mestranda da mesma academia, Ana Clara Elesbão, reflexionam sobre a criminalização de movimentos sociais e, em particular, o caso que no Brasil ficou conhecido pel“a primavera secundarista" ${ }^{\prime \prime}$. Consideram os autores que a democracia sai sempre beliscada quando um Estado neoliberal impõe socialmente a sua governabilidade com base em acções musculadas ou autoritárias, que in fine resumem-se a uma espécie de instrumentalização da justiça para servir os interesses públicos. Esta situação reflecte a contemporaneidade do "Direito Penal do Inimigo"6, pelo que urge repensar o Direito para preservar-se a cultura de paz universal que (de momento) vai sendo a tónica social predomimante no século XXI.

A primeira parte da obra encerra com o estudo das "dimensões do consenso no processo penal" na "matriz oculta da violência na modernidade", da autoria de Fabrício Pozzebon, Professor da PUCRS7. A reflexão conjugada dos conceitos de "violência", "consenso", "política criminal" e "direito processual", dos quais sobressai-se a análise da figura (controversa) da delação premiada vigente no ordenamento jurídico brasileiro e que passou recentemente a estar na nossa agenda política, conduziram o autor a identificar que a desarmonia entre o cronómetro legal e social tem contribuído para a diminuição das garantias juridico-processuais do indivíduo cntsruídas ao longo dos últimos séculos ou, até mesmo, para o precipício daquele modelo penal, dado que até o princípio do contraditório tem sido posto em causa. Em reacção, defende a continuidade de um modelo penal inclusivo, capaz de articular a violência e o consenso no sentido de adaptar o processo à complexidade e agilidade dos meandros criminosos, sem desprezo pelas garantias típicas de um Estado (Democrático) de Direito.

O primeiro estudo da (segunda) parte dedicada à "Tutela jurídica digital e laboral do e no século XXI", foi redigido pela Professora da Escola de Direito da Universidade do Minho, Isabel Celeste Fonseca, e pelo Mestre em Direito e Advogado, Vasco Cavaleiro. Foi pretensão dos autores ensaiar sobre a efectividade, ou não, da transparência da actividade

4 Idem nota de rodapé $n .^{\circ} 2$.

5 "A primavera secundarista" representou um movimento de tensão social marcado, por um lado, pela ocupação iliberal de escolas e de serviços responsáveis pelas políticas de educação no Brasil levada a cabo, essencialmente, por professores e alunos como forma de protesto contra o fecho de estabelecimentos por razões orçamentais, pugnando por um modelo de escola pública acessível à população e, assim, capaz de catapultar a sociedade para níveis superiores de instrução e inferiores de desigualdade. E, por outro, pela desocupação dos referidos espaços públicos conduzida pelas autoridades com base em intervenções, ainda que baseadas na legalidade, musculadas com vista a dissuadir a continuidade das reivindicações.

6 VALENTE, Manuel Monteiro Guedes. Direito Penal do Inimigo e Terrorismo. Lisboa: Almedina, 2019. ISBN 978972-4079-62-2.

7 Idem nota de rodapé n. ${ }^{\circ} 2$. 
da Administração Pública face à vigência do Regulamento Geral de Protecção de Dados (RGPD) no nosso ordenamento jurídico ${ }^{8}$. Em detalhe, debruçaram-se à luz dos princípios da legalidade e da proporcionalidade sobre a colisão do designado modelo aberto de actuação da Administração Pública (tal como está desenhado na $\mathrm{CRP}^{9}, \mathrm{CPA}^{10}$, $\mathrm{LADA}^{11}$ e $\mathrm{LPD}^{12}$, e que garante direitos e liberdades ao cidadão essenciais para equilibrar a sua relação com o Estado), com a execução do RGPD, este como instrumento legitminante para proteger (ou, quiçá, ocultar) dados que os serviços públicos cada vez mais armazenam e partilham na presente era das redes digitais. Ao discorrerem sobre a referida colisão foram identificando dificuldades conceptuais (como a diferença entre dados pessoais e nominativos) e materiais (associadas às restrições do direito de acesso por terceiros). Assim como, foram apontando caminhos para o RGPD não diminuir o controlo democrático da Administração feito pelos cidadãos (apelando ao resgate da ponderada jurisrpudência do CADA). De todo o modo, antevê-se que a dimensão deste problema tenha tendência para ampliar, chamando-se, por exemplo, à colação o modo de gestão por parte do Estado do designado Big Data que têm ao seu dispor, tendo em conta que actua ora como um ente dotado de ius imperium, ora como um mero particular, na qualidade de vendedor ou consumidor.

A segunda abordagem, epigrafada "A autotutela jurídica na era digital", da autoria do Procurador da República e Doutorando da UAL, José Ramos, resenha notavelmente as formas de autotutela vigentes e em que medida estas apresentam-se, ou não, adequadas e eficazes para a sua acção ser, nos tempos em que correm, exercida no campo digital. Identificando a necessidade de reformulação dos tipos de autotutela com vista à ampla harmonia do nosso ordenamento jurídico vigente com a realidade presente marcada pela intensa utilização dos meios digitais, o autor oferece o esboço de duas normas, intituladas de "Legítima defesa digital" e "Estado de necessidade digital". Ainda que estes tipos de autotutela sejam um mero esboço e não tenham sido aflorados outros aspectos conexos (como, por exemplo, a autotutela probatória), constata-se ter sido um primeiro passo ambicioso, dada a ausência de tratamento desta matéria em instrumentos internacionais, e decisivo para despertar a doutrina portuguesa a cogitar.

O terceiro artigo, intitulado "A tutela jurídica na era digital no quadro supanacional",

8 O diploma europeu relativo à proteção das pessoas singulares no que diz respeito ao tratamento de dados pessoais e à livre circulação desses dados, denominado commumente pela sigla RGPD, foi aprovado pelo Regulamento (UE) 2016/679 do Parlamento Europeu e do Conselho, de 27 de abril de 2016. Por sua vez, foi assegurado a execução daquele regulamento, na ordem jurídica portuguesa, através da aprovação da Lei n. ${ }^{0}$ 58/2019, publicada no Diário da República n. ${ }^{\circ}$ 151/2019, Série I de 8 de agosto de 2018.

9 Constituição da República Portuguesa.

10 Código do Procedimento Administrativo.

11 Lei de Acesso aos Documentos Administrativos.

12 Lei da Protecção de Dados Pessoais. 
manuscrito por Maria João Escudeiro, Professora Adjunta do ISCAL-IPL ${ }^{13}$ e Professora Auxiliar do ISCPCI ${ }^{14}$, problematiza a viabilidade, ou não, de criar-se uma simbiose entre as novas tecnologias e os direitos humanos. A autora aponta laconicamente que as mudanças permamentes da sociedade por influência das evoluções tecnológicas desafiam o Direito a adaptar-se e a reconstruir-se, prevendo que somente uma ciência normativa orientada para a tutela da dignidade da pessoa humana e reserva da intimidade da vida privada possa almejar a parceria ideal entre a tecnologia e o Direito. De todo o modo será seguramente uma tarefa muito árdua para os juristas dado que a evolução tecnológica ocorre a cada nano-segundo, ao invés do Direito, bastando in casu evocar o burocracismo legiferante, ainda que este varie consoante o órgão ou o Estado.

O quarto tema apresentado pelo Advogado Cláudio Carneiro aborda, em tese, o modelo actual dos direitos fundamentais de segunda geração, designados por direitos sociais (tais como, a educação, a saúde, o trabalho, a habitação), como sendo garante, ou não, da promoção da igualdades na comunidade. Neste contexto, começa por apregoar que a boa governança deve estar presente numa "Neoconstituição" como um direito fundamental, de modo a que os direitos sociais evoluam da dimensão programática, como tradicionalmente são emoldurados, para uma dimensão de exequibilidade fruto de uma actividade estadual proactiva e capaz de colmatar as reais necessidades dos cidadãos. Porém, o autor contrabalança esse desígnio e realça a ineficácia do sistema estadual quando evoca as limitações financeiras ou orçamentais para condicionar a concretização dos direitos sociais. A teoria da "reserva do possível" é, assim, considerada como uma espécie de travão da efectivação dos direitos sociais. Deste modo, o tempo urge e é necessário conceber soluções, as quais poderão não ser um mito intangível dado que têm vindo a ser desenvolvidas teorias financeiras baseadas na ética e solidariedade, que priorizam o bem-estar das pessoas em detrimento dos principais traços do capitalismo.

O último escrito apresentado por Carlos Proença, Professor Auxiliar da UAL, Professor Adjunto do ISCAL-IPL ${ }^{15}$ e Advogado, debruça-se sobre o direito a partir de uma óptica legal europeísta e na linha de investigação da tutela do trabalhador na era digital. Neste sentido e após percorrer os principais instrumentos de dimensão europeia ${ }^{16}$, o autor exalta que dignidade do trabalhador é uma manifestação da dignidade da pessoa humana e, como tal, deve-se continuar a apostar na tutela do trabalhador pois persiste a posição de fraqueza

13 Instituto Superior de Contabilidade e Administração de Lisboa do Instituto Politécnico de Lisboa.

14 Instituto Superior de Ciências Policiais e Segurança Interna.

15 Ibidem nota rodapé n. ${ }^{\circ} 13$.

16 A Convenção Europeia dos Direitos Humanos, a Carta dos Direitos Fundamentais da União Europeia, a Carta

Social Europeia e a Carta Comunitária dos Direitos Sociais Fundamentais dos Trabalhadores. 
GALILEU · e-ISSN 2184-1845 - Volume XX · Issue Fascículo 2 - $1^{\text {st }}$ July Julho $-3^{\text {th }}$ December Dezembro 2019 - pp. $203-208$

face ao empregador, agora também motivada ou agravada pela globalização e evolução tecnológico-digital que tem invadido o mercado laboral. Enaltece, ainda, os contributos das políticas e normas da União Europeia na construção de um mercado único pensado para respeitar e servir as pessoas/trabalhadores, ainda que haja um caminho a desbravar no sentido da harmonização comunitária que promova o binómio liberdade-igualdade, o qual se antevê complexo dado serem significativas as diferenças socio-económicas e políticas existentes entre os diversos Estados-membros.

Destarte, conclui-se a recensão da obra com a segurança que, por mérito dos autores, o exame de múltiplos temas afectos aos desafios que o Direito enfrenta no século XXI focados ora no eixo "Direito-Violência", ora na tutela jurídica da personalidade no domínio digital e laboral - elevou uma série de assun- tos relevantes e prementes para instigar a reflexão na academia científica com vista à cooperação interpares no aperfeiçoamento dos ordenamentos jurídicos. Os artigos oferecem, ainda, diversos contributos para a evolução da cultura jurídica no sentido de reformar-se o Estado de Direito, rumo a um futuro de reconhecimento pleno da dignidade da pessoa humana e, por sua vez, de afirmação de uma sociedade livre, igual, justa e solidária.

* Doutorando em Ciências Jurídicas da Universidade Autónoma de Lisboa.

\section{Como citar esta Recensão Bibliográfica:}

CARVALHO, Emanuel (2020). Recensão Crítica de: VALENTE, Manuel Monteiro Guedes (Coord.). Os desafios do direito do século XXI: violência, criminalização, consenso, tutela digital e laboral. Coimbra: Almedina, 2019. 196 p. ISBN 978-972-40-8224-0. 


\section{RECENSÃO CRÍTICA ${ }^{1}$}

\section{VALENTE, Manuel Monteiro Guedes (Coord.) - "Criminalidade Organizada Transnacional", Corpus Delicti - I, Coimbra: Almedina, 2019. ISBN 978-972-40-8223-3.}

\section{POR INÊS FARINHA}

inesimoesf@gmail.com

GALILEU - REVISTA DE DIREITO E ECONOMIA · e-ISSN 2184-1845

Volume XX $\cdot 1^{\text {st }}$ July Julho $-31^{\text {TH }}$ December Dezembro $2019 \cdot$ pp. 209-212

DOI: http://doi.org/10.26619/2184-1845.XX.2.1.03

A obra ora objeto da presente recensão congrega o contributo de vários estudiosos do Direito no domínio da sempre intrincada e não menos carente de discussão - criminalidade organizada transnacional. Sob o título Corpus Delicti: Estudos de Criminalidade Organizada Transnacional, que se insere no escopo investigativo da Law and Governance do Ratio Legis (Centro de I\&D de Direito da Universidade Autónoma de Lisboa) são dissecados vários trechos de análise que aprofundam celeumas bem como os avanços legislativos e científicos recentemente produzidos.

A obra invoca ademais a necessidade de compreender o fenómeno da criminalidade organizada a qual se vê embrenhada em esti- lismos conceptuais afins o que, como bem aponta MANUEL Guedes VALENTE ${ }^{2}$, concorre para a germinação do ideal securitário3. Isto porque a noção de criminalidade organizada perde fulgor para outros conceitos como os de criminalidade de massa, itinerante ou de rua, bandos criminosos ou associações criminosas.

A complexificação das formas e fórmulas criminógenas ínsitas ao aparecimento de novas tipologias criminais, que ultrapassam muitas vezes a nossa capacidade de as inteligir, assentam na desenfreada germinação de uma sociedade "fractal, policêntrica e multiterritorial" que encobre a vasta tessitura de poderes e vulnerabilidades dos Estados

\footnotetext{
1 Como citar este artigo: Farinha, Inês Simões (2020). Recensão Crítica de: VALENTE, Manuel Monteiro Guedes (Coord.) - "Criminalidade Organizada Transnacional", Corpus Delicti - I, Coimbra: Almedina, 2019. ISBN 978-972-40-8223-3.

2 O autor, ao longo do seu artigo intitulado "Criminalidade organizada Transnacional: um estudo crítico jurídico-político emergente", tece críticas contundentes à forma como se efetiva a prevenção e repressão da criminalidade organizada dado que a difusividade conceitual entorpece a positivação normativa ao nível interno. Neste caso estamos a falar na transposição da Decisão-Quadro 2002/475/JAI na Lei de Combate ao Terrorismo, Lei n. ${ }^{\circ}$ 52/2003, de 22 de Agosto.

3 Para melhor situar o desiderato securitário ínsito ao direito penal do autor vs direito penal do ser humano, vide Valente, Manuel Monteiro Guedes - Direito Penal do Inimigo e o Terrorismo, o "progresso ao retrocesso", $3 \cdot{ }^{\text {a }}$ Edição, Almedina, 2019.
} 
que são concomitantemente incubadores do vírus e motores de combate a estes fenómenos. Quem assim discerne é ANABELA MirANDA Rodrigues que vivifica - dir-se-ia até num discurso de quasi contradição - o fenómeno da criminalidade organizada como uma inevitabilidade ante um mal, de per si, desnecessário, ao qual, no entanto, tem sido dada resposta através de múltiplas estruturas ${ }^{4}$ erigidas sob o sacrossanto princípio do reconhecimento mútuo.

A dupla face da edificação do crime organizado é nesta obra dissecada por LAURA RODRÍGUEZ que decompõe criminologicamente o conceito de corporate crime e aponta caminhos e propostas de prevenção. Não se olvide que a escolha de estruturas logicamente assentes numa base legitimada pela lei, principalmente orientadas para o lucro, vêm entorpecendo e pervertendo o funcionamento do sistema globalmente considerado, que força o surgimento de uma ampla aparelhagem de táticas que escondem práticas criminais, como é o caso das sociedades offshore. A permanente reprodução e difusão destas práticas faz mover a mão do legislador para que seja pródigo na previsão de medidas efetivas. Disso é exemplo a Diretiva 2018/1673, de 23 de outubro, relativa ao branqueamento de capitais que veio completar um quadro legal que se mostrava impotente face à luta contra a criminalidade organizada, no que respeita ao embargo e confisco de bens produto do crime, cristalizando-se depois com a adoção do Regulamento (UE) 2018/1805 .

As sendas do crime organizado também se entretecem na bipolarização entre as razões que levam a delinquir e o modo de controlo e repressão do comportamento desviante. A fórmula apresentada por GUILHERME WERNER toca as idiossincrasias do fenómeno da corrupção cuja raiz emerge em ambientes propícios que fazem nascer um verdadeiro Direito Penal do Amigo que se alimenta no e para o Estado, e floresce dentro das cátedras em que o poder político e económico se encontram inseridos. Principalmente num país, como é o Brasil, em que a tão almejada quebra de ciclos viciosos se vai conquistando a pari passu com o desenvolvimento de estruturas aptas a combatê-los. Aliás o Brasil tem sido um dos países que tem investido, à semelhança de outros países da América Latina, na criação de órgãos de repressão do crime em larga escala, em específico no combate ao crime organizado e à corrupção, como é o caso da Polícia Federal, embora, como denota ANTHONY Pereira, tal tenha sido feito tarde. Contudo, a desmontagem através da investigação e perseguição criminal de uma das mais importantes redes de corrupção, que ficou conhecida como "Operação Lava Jato", traz à colação a necessidade de reconhecer que aquele órgão de polícia foi e é determinante no combate à corrupção e possivelmente de

4 Estamos aqui a falar naturalmente do mandado de detenção europeu, mecanismo que veio solidificar o que a autora apelida de "judiciarização da cooperação".

5 Este Regulamento prevê o reconhecimento mútuo de resoluções de embargo e confisco de bens. 
servir como case study para outros órgãos de polícia criminal congéneres.

A quebra de barreiras transfronteiriças, a mutação geopolítica de conflitos armados e o clima generalizado do medo, fizeram emergir os crimes de tráfico de pessoas e de auxílio à imigração ilegal, os quais se mostram como realidades distintas e que carecem de sistematização para que se possam captar estratégias de prevenção mais eficazes, como bem sintetizou MARIA JoÃo GUIA.

Por seu turno, para MARIA JoÃo EsCUDEIRO, os intentos de pacificação da desordem mundial e dos conflitos internacionais fizeram com que se criasse o Tribunal Penal Internacional (TPI), que se assumiu essencialmente como uma instituição de combate às atrocidades do século XX. Mas essencialmente, porque tais atrocidades se metamorfosearam nas tipologias de crimes como o terrorismo ou o tráfico de droga, o TPI pode ser uma via de solução de cooperação entre os estados e na promoção dos direitos humanos a uma escala global.

A necessidade de criar meios consistentes no combate ao crime organizado transnacional não pode cingir-se, como bem lembra GIULIU ILLUMINATI, a respostas contidas e cegamente submissas ao princípio da soberania territorial. Este autor sublinha para a inevitabilidade da procura de uma resposta conjunta, através da cooperação penal entre os Estados, que pode sucumbir quando, através do uso de meios tecnológicos (técnicas de investigação como a vigilância eletrónica) não se privilegiem os princípios basilares penais e processuais penais com respeito último pela proteção dos indivíduos. Por isso as garantias processuais mínimas, as quais divergem de Estado para Estado, devem ser asseguradas a um nível transnacional, quais sejam as do respeito pelo direito de defesa do arguido ou a legalidade da prova e dos meios de obtenção de prova.

Germano Marques da Silva encerra com chave de ouro o ciclo do debate que a presente conferência proporcionou. Segundo aquele autor, num tempo marcado pela guerra aberta ao crime, sobretudo ao grave e com intentos transnacionais, em que o próximo se rotula de "inimigo", importam-se riscos para o funcionamento da própria democracia. A tónica percebida e acolhida por este autor é senão a de questionar até que ponto deverão ceder os princípios, como a presunção da inocência, ou direitos, como o da reserva, em favor da tão propalada e feroz luta contra a criminalidade organizada. Não é também de menosprezar a ênfase dada à crítica frontal da delação premiada, quando inexista arrependimento, uma matéria que tem agitado mais recentemente os cientistas do direito, tanto em Portugal como além-mar.

Do iter brevemente percorrido concordamos na essencialidade que a presente obra representa e aquilo que nos presenteia: de um lado, trazendo para a reflexão científica toda uma nova toponímia associada ao crime organizado transnacional, quer pela necessidade de fixar concetualmente os tipos e subtipos de ilícitos criminais, quer ainda pelo reconhecimento de que os direitos penal e processual 
penal, apesar dos sentidos esforços, nomeadamente legislativos, não têm dado, de forma sistêmica e concêntrica, uma resposta cabal e efetiva ao fenómeno do crime organizado.

A nova geografia mundial orientada para a paulatina abolição transfronteiriça de controlos, quer de pessoas, quer de bens, faz emergir toda uma moderna criminalidade, cada vez mais amestrada na sua técnica e dotada de uma capacidade de diluição dos seus efeitos de forma célere e articulada.

A obra ora recenseada tem um condão muito próprio que mais não é o de apontar para a dicotomia existente entre a emergência de espaços - tanto ao nível regional como internacional - onde florescem novas formas de criminalidade e, concomitantemente, a anunciada falência dos sistemas, que ainda optam por formas de repressão e controlo, no essencial, internos ${ }^{6}$.

Cremos, per summa capita, ter apontado as linhas gerais em que se estriba a obra a que nos dispusemos recensear. Não sendo pretensão da mesma esgotar todas as frentes de análise de uma realidade que é maior do que si própria, é pródiga em pelo menos elencar trechos de debate e linhas de orientação para os variados setores que acompanham o estudo e aplicação desta temática.
Estamos convictos de que futuras abordagens ao tema deverão incluir perspetivas de outras ciências satélite do Direito, que tanto o enriquecem, quais sejam as ciências da Criminologia, da Sociologia, da Psicologia, entre outras, que devem sempre, na nossa ótica, convergir para a desmontagem e dilucidação de problemas que envolvem a teorização do Direito Penal, em especial, as novas latitudes que o enformam e que nesta obra se deixaram limadas.

Não podíamos terminar esta excursão sem dar uma nota quanto à problemática da execução das penas quando pensada no seio da criminalidade organizada. A colocação da questão não é despicienda e cremos haver consenso quanto à necessidade de a ver tratada. A velha e corcunda discussão dos fins das penas, a tipologia de penas previstas no nosso catálogo, a desadequação do meio prisional na reinserção do delinquente, a reincidência... são questões que também devem merecer ponderação científica e profunda reflexão, se quisermos, a final, alinhar no mesmo diapasão - o do combate efetivo à criminalidade organizada transnacional.

\footnotetext{
* Doutoranda em Ciências Jurídicas da Universidade Autónoma de Lisboa
} 
